UNIVERSIDADE DE SÃO PAULO

FACULDADE DE FILOSOFIA, LETRAS E CIÊNCIAS HUMANAS

DEPARTAMENTO DE LETRAS CLÁSSICAS E VERNÁCULAS

PROGRAMA DE PÓS-GRADUAÇÃO EM FILOLOGIA E LÍNGUA PORTUGUESA

O ETHOS E O PATHOS NO HIPERGÊNERO "PRIMEIRA PÁGINA" ANÁLISE DISCURSIVA DAS EDIÇÕES DE ABRIL DE 1964 DOS DIÁRIOS CORREIO DA MANHÃ E O GLOBO

Eduardo Lopes Piris

Orientadora: $\operatorname{Prof}^{\mathrm{a}} \mathrm{Dr}^{\mathrm{a}}$ Lineide do Lago Salvador Mosca

VERSÃO REVISADA

SÃO PAULO

2012 
UNIVERSIDADE DE SÃO PAULO

FACULDADE DE FILOSOFIA, LETRAS E CIÊNCIAS HUMANAS

DEPARTAMENTO DE LETRAS CLÁSSICAS E VERNÁCULAS

PROGRAMA DE PÓS-GRADUAÇÃO EM FILOLOGIA E LÍNGUA PORTUGUESA

O ETHOS E O PATHOS NO HIPERGÊNERO "PRIMEIRA PÁGINA" ANÁLISE DISCURSIVA DAS EDIÇÕES DE ABRIL DE 1964 DOS DIÁRIOS CORREIO DA MANHÃ E O GLOBO

Eduardo Lopes Piris

Orientadora: $\operatorname{Prof}^{\mathrm{a}} \mathrm{Dr}^{\mathrm{a}}$ Lineide do Lago Salvador Mosca

VERSÃO REVISADA

SÃO PAULO

2012 
UNIVERSIDADE DE SÃO PAULO

FACULDADE DE FILOSOFIA, LETRAS E CIÊNCIAS HUMANAS

DEPARTAMENTO DE LETRAS CLÁSSICAS E VERNÁCULAS

PROGRAMA DE PÓS-GRADUAÇÃO EM FILOLOGIA E LÍNGUA PORTUGUESA

\title{
O ETHOS E O PATHOS NO HIPERGÊNERO "PRIMEIRA PÁGINA" ANÁLISE DISCURSIVA DAS EDIÇÕES DE ABRIL DE 1964 DOS DIÁRIOS CORREIO DA MANHÃ E O GLOBO
}

\author{
Eduardo Lopes Piris
}

Tese apresentada ao Programa de PósGraduação em Filologia e Língua Portuguesa do Departamento de Letras Clássicas e Vernáculas da Faculdade de Filosofia, Letras e Ciências Humanas para obtenção do título de Doutor em Letras: Filologia e Língua Portuguesa.

Orientadora: Prof ${ }^{\mathrm{a}} \mathrm{Dr}^{\mathrm{a}}$ Lineide do Lago Salvador Mosca

VERSÃO REVISADA 


\section{BANCA EXAMINADORA}

Profa. Dra. Lineide do Lago Salvador Mosca (Orientadora) Faculdade de Filosofia, Letras e Ciências Humanas

Universidade de São Paulo

\section{Assinatura}

Profa. Dra. Leda Verdiani Tfouni

Faculdade de Filosofia, Ciências e Letras de Ribeirão Preto Universidade de São Paulo

\section{Assinatura}

Profa. Dra. Maria Rosa Duarte de Oliveira

Faculdade de Filosofia, Comunicação, Letras e Artes

Pontifícia Universidade Católica de São Paulo

\section{Assinatura}

Profa. Dra. Ana Rosa Ferreira Dias

Faculdade de Filosofia, Letras e Ciências Humanas Universidade de São Paulo

\section{Assinatura}

Profa. Dra. Helena Hathsue Nagamine Brandão

Faculdade de Filosofia, Letras e Ciências Humanas Universidade de São Paulo 


\section{DEDICATÓRIA}

Aos meus pais, José Eustáquio Piris e Onilda Lopes Piris, Aos meus irmãos, Silmara Lopes Piris e Tadeu Lopes Piris, Aos meus filhos:

Mateus Fonseca Piris, Guilherme Fonseca Piris e Lavínia de Lima Piris, À minha companheira, Jacqueline de Lima. 


\section{AGRADECIMENTOS}

Embora a responsabilidade pelo trabalho seja toda nossa e nos isolemos diante do nosso computador, não estamos sós nessa empreitada. Neste trabalho, pude sentir como a heterogeneidade enunciativa é constitutiva, pois dialogamos com o discurso das Ciências da Linguagem, da Teoria da Argumentação, da Análise do Discurso etc., mas também pude experimentar como essa heterogeneidade é, igualmente, mostrada e marcada, porque tive a sorte de compartilhar com mestres e colegas momentos de sabedoria, de generosidade, de parceria e de amizade.

Em primeiríssimo lugar, quero agradecer à professora Lineide Salvador Mosca pela orientação e, principalmente, pela confiança depositada no meu trabalho desde o aceite na seleção em julho de 2007 e pela paciência que teve comigo durante esses nove semestres.

Agradeço também à Jacqueline de Lima, minha companheira, pelo diálogo no início da tese sobre as questões em torno da metodologia científica e pela ajuda na transcrição dos dados da pesquisa, bem como pela sua preocupação durante todos os momentos, sobretudo na reta final.

No início deste doutorado, cursei disciplinas com três professoras cujas lições não se apagarão. Por isso, agradeço às professoras Elizabeth Harkot-de-La-Taille, Marisa Grigoletto, Alice Miitika Koshiyama.

A preparação e a apresentação de cada Seminário do GERAR, as defesas de doutorado, o PAE, as idas ao GEL, as despedidas de final de ano na casa da professora Lineide (obrigado "Seu" Domingos!) foram oportunidades em que pude ver que os amigos estavam ali. Agradeço a todos os colegas do GERAR, especialmente aos colegas com os quais tive a oportunidade de trabalhar, Moisés Olímpio Ferreira, Elizabete Enz Hubert, Cleonice Men da Silva Ramos, Maria Helena Cruz Pistori, Heitor Bittencourt, Adriano Dantas de Oliveira, Josely Teixeira Carlos e Margibel Adriana de Oliveira.

Essa fraternidade extrapolou o círculo do GERAR, pois os companheiros que construíram o EPED comigo vieram de tantos outros 'lugares' de nossa pósgraduação. Em primeiro lugar, minha "amigona” Bianca Rigamonti Valeiro Garcia, que foi a primeira colega a aceitar o desafio de criar e manter um evento sobre Análise do Discurso na Universidade de São Paulo. Valeu, Bianca! E, completando a trupe de corajosos que não apenas colocaram o EPED em nosso calendário de 
eventos, mas que se tornaram pessoas muito queridas para mim, meu muito obrigado à Cleide Lúcia da Cunha Rizério e Silva, à Flávia Sílvia Machado Ferraz e ao Paulo Roberto Gonçalves Segundo. Tão importante quanto começar é dar continuidade ao trabalho, assim juntaram-se a nós, nessa empreitada, Daniela da Silveira Miranda, Josely Teixeira Carlos, Simone Ribeiro de Ávila Veloso, Luiz André Neves de Brito e Artarxerxes Tiago Tácito Modesto, com os quais aprendi muito. A vocês, meus sinceros agradecimentos!

Agradeço, também, aos meus ex-alunos da antiga Faculdade Montessori de Ibiúna. Com a $1^{\underline{a}}$ turma de Letras, tive a oportunidade de orientar os primeiros TCCs em Análise do Discurso. Já a 3a turma de Letras me deu a imensa alegria, quando mostraram gosto pela Linguística, que era o bicho-papão do curso de Letras, e, mesmo após a minha saída da empresa, persistiram no "erro" e fizeram seus TCCs em Linguística.

Voltando ao nosso Programa de PG em Filologia e Língua Portuguesa, pergunto quem nunca precisou do pessoal da secretaria? Dayane e Elias, muito obrigado pelos serviços e informações prontamente prestados durante o meu estágio no PAE, o preenchimento do relatório CAPES, a realização do EPED e em todos os momentos necessários.

Sim, agradeço também ao CNPq pela bolsa concedida, que foi por pouco tempo, mas que ajudou bastante.

Agradeço ao professor Manoel Mourivaldo Santiago Almeida e às professoras Sheila Vieira de Carvalho Grillo e Elis de Almeida Cardoso Caretta pelas inestimáveis lições que tive, quando - com eles - participei da Comissão Coordenadora do Programa de PG em Filologia e Língua Portuguesa, entre 2007 e 2009.

Agradeço à Universidade de São Paulo (USP), que sempre foi a minha casa (literalmente, porque fui morador do CRUSP), e à Universidade Estadual de Santa Cruz (UESC), que é a minha nova casa, pela estrutura e oportunidade oferecidas a $\operatorname{mim}$.

Ocorre que, durante o doutorado, tive a felicidade de ser aprovado no concurso para professor de Língua Portuguesa da Universidade Estadual de Santa Cruz (UESC). A isso devo muito ao Carlos Augusto Martins, que me deu a notícia do concurso, e ao Bruno Oliveira Maroneze, que me deu dicas preciosas para concursos desse tipo. Muito obrigado! Nunca vou esquecer. 
Já na UESC, nasceu a Revista EID\&A, a qual, com toda certeza, eu não teria conseguido criar se não tivesse encontrado uma parceria séria, generosa e muito disposta a trabalhar. Por isso, agradeço ao Moisés Olímpio Ferreira e, também, à sua companheira e também minha amiga, Kelly Cristina de Oliveira.

E, aos meus atuais alunos de Linguística IV (Análise do Discurso) e orientandos de Iniciação Científica da Universidade Estadual de Santa Cruz, pela oportunidade de discutir e amadurecer conhecimentos, meus agradecimentos.

$\mathrm{Na}$ reta final dessa aventura, destaco a participação das professoras Ana Rosa Ferreira Dias e Helena Nagamine Brandão pela participação na banca de qualificação e pelo diálogo que foi inesquecível. Meus agradecimentos!

Ainda na reta final, pela consultoria em assuntos de língua inglesa e de língua francesa, meu muito obrigado ao Laurenci e ao Moisés, respectivamente.

E, ao final de tudo, ao meu amigo Marcelo Ruis Vargas, pela acolhida em São Paulo para o fechamento dos últimos detalhes e impressão da tese.

Por fim, agradeço a Deus por me dar saúde e sempre um novo dia de vida, sem os quais nada disso é possível.

Muito obrigado! 
Ao invés de tomar a palavra, gostaria de ser envolvido por ela e levado bem além de todo começo possível. Gostaria de perceber que, no momento de falar, uma voz sem nome me precedia há muito tempo. Eu não queria ter de entrar nesta ordem arriscada do discurso. E a instituição responde: "Você não tem por que temer começar; estamos todos aí para lhe mostrar que o discurso está na ordem das leis; e que, se lhe ocorre ter algum poder, é de nós, só de nós, que ele lhe advém" (Michel Foucault, 1971). 


\section{RESUMO}

Esta pesquisa situa-se na interface entre a Análise do Discurso e a Teoria da Argumentação no Discurso e visa a proceder à análise discursivo-argumentativa das primeiras páginas das edições de abril de 1964 dos jornais Correio da Manhã e $O$ Globo. As análises mostram de que maneira o pathos contribui para a construção do ethos no discurso jornalístico, constatando como as emoções (ainda que não mostradas explicitamente no enunciado) participam da construção do posicionamento e da identidade discursiva dessas empresas de comunicação num momento específico de crise política. Para tanto, considera a produção desses discursos no bojo de uma relação polêmica controversa entre duas formações discursivas diametralmente opostas, a saber: uma "revolucionária" e uma "antigolpista". Quanto aos procedimentos teórico-metodológicos da pesquisa, a depreensão da qualidade do pathos e do ethos discursivos baseou-se na análise da composição do layout da primeira página, da inter-relação dos gêneros jornalísticos no hipergênero "primeira página jornalística", e do cenário passional. Os resultados da pesquisa revelam que as paixões construídas nas primeiras páginas do Correio da Manhã e d'O Globo projetam dois ethé jornalísticos bem distintos que legitimam a enunciação de discursos com diferentes posicionamentos sobre o movimento político de 1964. Por fim, a pesquisa conclui o vínculo entre o pathos, o ethos, o posicionamento e a identidade discursiva de cada jornal no interior da polêmica entre as formações discursivas "revolucionária" e "antigolpista".

Palavras-chave: Discurso. Argumentação. Hipergênero. Ethos. Pathos. 


\begin{abstract}
This research lies at the interface between the Discourse Analysis and the Theory of Argumentation in Discourse and aims to examine the discursive-argumentative analysis of the front pages of the newspapers Correio da Manhã and $O$ Globo published on April, 1964. The analysis show how the pathos contributes to the construction of the ethos in the journalistic discourse, evidencing how the emotions (though they are not explicitly shown in the enunciate) participate in the construction of the positioning and the discursive identity of these media companies in a specific moment of political crisis. To this end, we consider the production of these discourses inserted in a polemical and controversial relationship between the two discursive formations diametrically opposed, namely: a "revolutionary" and an "anti-coup d'etat". As for the theoretical and methodological procedures of the research, the apprehension of the quality of the discursive pathos and the ethos is based on the analysis of the composition of the front page's layout, the interrelationship of the journalistic genres in the hypergenre "front page", and the passional scenario. The results show that the passions constructed on the front pages of the Correio da Manhã and $O$ Globo project two very distinct journalistic ethé which legitimize the enunciation of discourses of different positioning about political movement of 1964 . Finally, we conclude the link between pathos, ethos, the positioning and the discursive identity of each journal in the interior of the controversy between the "revolutionary" and "anti-coup d'etat" discursive formations.
\end{abstract}

Keywords: Discourse. Argumentation. Hypergenre. Ethos. Pathos. 


\section{RÉSUMÉ}

Cette recherche se situe dans l'interface entre l'Analyse du Discours et la Théorie de l'Argumentation dans le Discours et vise à procéder à l'analyse discoursiveargumentative de la Une des éditions d'avril 1964 des journaux Correio da Manhã et $O$ Globo. Les analyses présentent la manière comme le pathos contribue à la construction de l'ethos dans le discours journalistique en remarquant la façon dont les emotions (même si elles n'ont pas été indiquées explicitement dans l'énoncé) participent à la construction du positionnement et de l'identité discursive des entreprises de presse dans un moment spécifique de crise politique. À cette fin, on envisage la production des discours à l'intérieur d'une relation polémique controversée entre deux formations discursives diamétralement opposées, à savoir: une "révolutionnaire" et une "anti-coup d'état". À l'égard des procédures théoriquesméthodologiques de la recherche, la saisie de la qualité du pathos et de l'ethos a été basée sur l'analyse de la composition de l'aménagement de la Une, de l'interrelation des genres journalistiques dans l'hypergenre "la Une", et du scénario passionnel. Les résultats révèlent que les passions produites par les discours du Correio da Manhã et du $O$ Globo projetent deux ethe très distincts, lesquels légitiment l'énonciation des discours avec positionnements opposés sur le mouvement politique de 1964. On conclut, donc, le lien entre le pathos, l'ethos, le positionnement et l'identité discursive de chaque journal à l'intérieur de la polémique entre les FDs "révolutionnaire" et "anti-coup d'état".

Mots-clés: Discours. Argumentation. Hypergenre. Ethos. Pathos. 


\section{LISTA DE FIGURAS}

Figura 1 - Primeira página do Correio Braziliense, edição de 01.06 .1808 ...............85

Figura 2 - Primeira página d'A Gazeta do Rio de Janeiro, edição de 10.09.1808 ....86

Figura 3 - Primeira página d'O Estado de São Paulo, edição de 31.03 .1964 ..........87

Figura 4 - Primeira página da Folha de São Paulo, edição de $31.03 .1964 \ldots \ldots \ldots \ldots . . . .88$

Figura 5 - Primeira página do Correio da Manhã, edição de 02.04.1964.................97

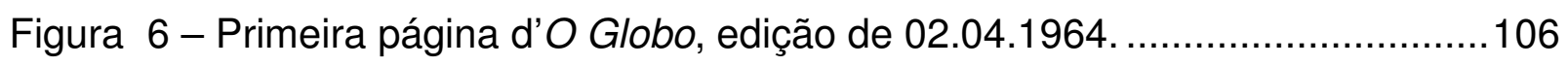

Figura 7 - Primeira página do Correio da Manhã, edição de 03.04.1964................112

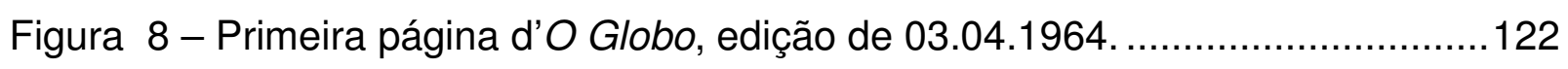

Figura 9 - Primeira página do Correio da Manhã, edição de 10.04.1964................128

Figura 10 - Primeira página d'O Globo, edição de 10.04.1964 ..............................136

Figura 11 - Gêneros verbais e verbo-visuais no Correio da Manhã.......................... 149

Figura 12 - Gêneros verbais e verbo-visuais n'O Globo .......................................150

Figura 13 - Fotografia da foto-manchete da capa d'O Globo de $03.04 .64 \ldots \ldots \ldots \ldots . . .180$

Figura 14 - Fotografias das fotos-legendas d'O Globo de 03.04.1964.................... 187

Figura 15 - Fotografia da foto-manchete do Correio da Manhã, de 10.04.1964 .....206

Figura 16 - Fotografia da foto-manchete d'O Globo, de 10.04.1964 ......................206 


\section{LISTA DE QUADROS}

Quadro 1 - Tópica das emoções, segundo esquema de Plantin (2010 [1998]) .......55

Quadro 2 - Transcrição da primeira página do Correio da Manhã de 02.04.1964 ....98

Quadro 3 - Transcrição da primeira página d'O Globo de 02.04.1964 ..................107

Quadro 4 - Transcrição da primeira página do Correio da Manhã de 03.04.1964 ..113

Quadro 5 - Transcrição da primeira página d'O Globo de 03.04.1964....................123

Quadro 6 - Transcrição da primeira página do Correio da Manhã de 10.04.1964 ..129

Quadro 7 - Transcrição da primeira página d'O Globo 10.04.1964.......................137

Quadro 8 - Títulos das capas do Correio da Manhã e d'O Globo de 02.04.1964 ...159

Quadro 9 - Títulos das capas do Correio da Manhã e d'O Globo de 03.04.1964 ...179

Quadro 10 - O discurso citado em "Lyndon Johnson envia felicitações a Mazzilli”...193

Quadro 11 - Títulos das capas do Correio da Manhã e d'O Globo de 10.04.1964 ..204 


\section{SUMÁRIO}

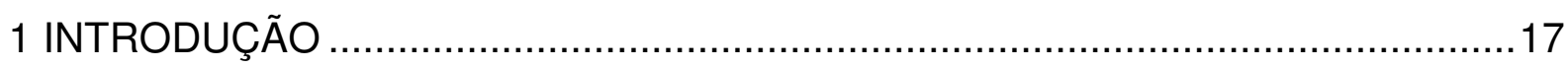

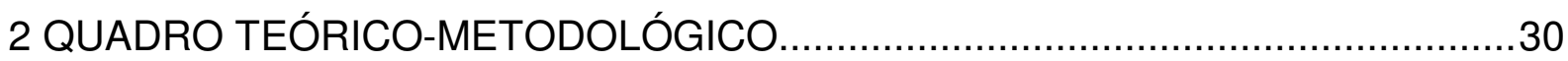

2.1 Pressupostos teóricos para a análise da argumentação no discurso ...............30

2.1.1 Argumentação e Análise do Discurso ..................................................30

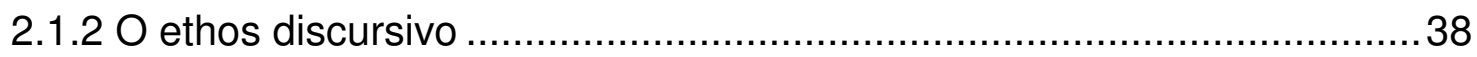

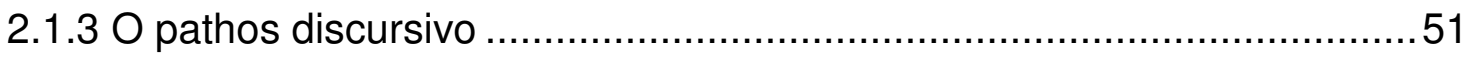

2.2 A primeira página do jornal: um hipergênero do discurso ...............................70

2.2.1 Localizando os problemas da primeira página do jornal ........................70

2.2.2 Tipologias genéricas, hipergênero e cenas de enunciação .....................76

2.2.3 A primeira página e a imagem do jornal e do leitor.................................83

3 PROCEDIMENTOS METODOLÓGICOS DA PESQUISA ...................................91

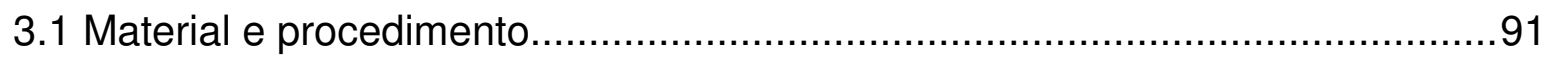

3.2 Constituição do corpus da pesquisa ........................................................93

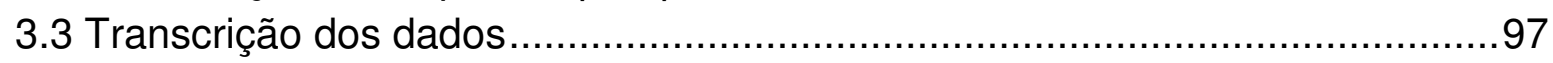

3.3.1 Transcrição das primeiras páginas de 2 de abril de 1964 ....................97

3.3.1.1 Correio da Manhã, 02.04.1964 ...........................................97

3.3.1.2 O Globo, 02.04.1964 .................................................... 106

3.3.2 Transcrição das primeiras páginas de 3 de abril de 1964 ...................112

3.3.2.1 Correio da Manhã, 03.04.1964 ............................................112

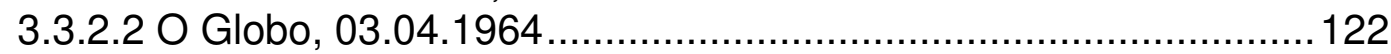

3.3.3 Transcrição das primeiras páginas de 10 de abril de 1964 .................128

3.3.3.1 Correio da Manhã, 10.04.1964 ............................................128

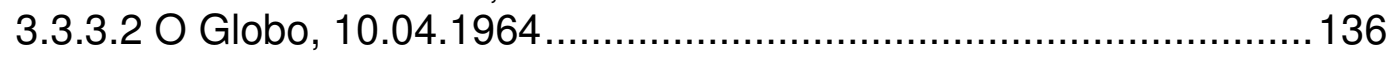

4 ANÁLISE DO CORPUS DA PESQUISA ..........................................................143

4.1 O contexto sócio-histórico da produção dos discursos jornalísticos ...............143

4.1.1 O cenário político brasileiro em 1964 e as formações discursivas .......143

4.1.2 Composição das forças sociais ditas "revolucionárias" ....................... 145

4.2 O hipergênero "primeira página" no Correio da Manhã e n'O Globo ..............149

4.2.1 O discurso gráfico-visual dos jornais ................................................. 149

4.2.2 Características dos gêneros das primeiras páginas dos jornais ............155

4.3 Análise das primeiras páginas das edições de 2 de abril................................159

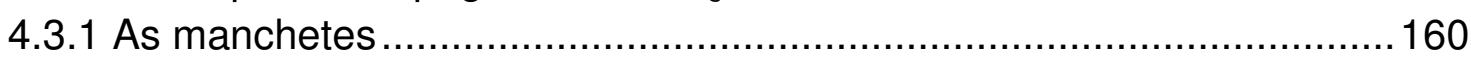

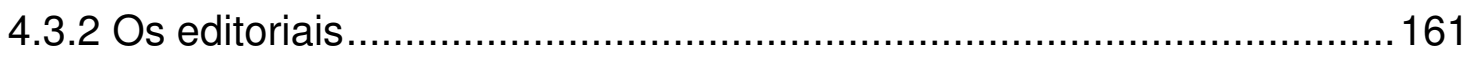

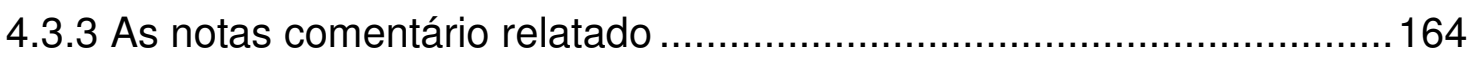

4.3.4 Os gêneros verbo-visuais: a foto-manchete e a foto-legenda ..............170

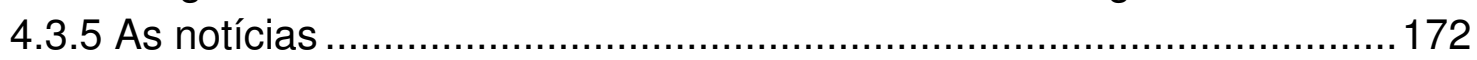

4.3.6 Os pathé e os ethé das primeiras páginas .........................................173

4.4 Análise das primeiras páginas das edições de 3 de abril..............................179

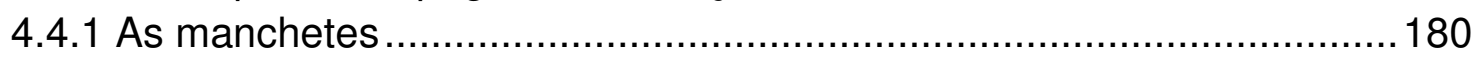

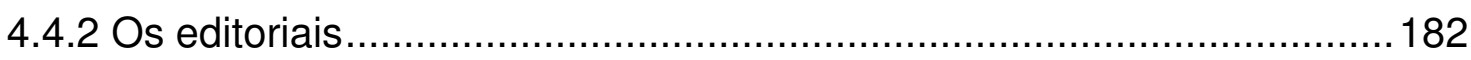




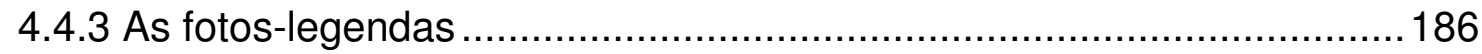

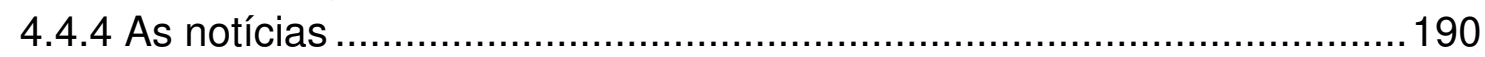

4.4.5 Os pathé e os ethé das primeiras páginas .......................................196

4.5 Análise das primeiras páginas das edições de 10 de abril............................204

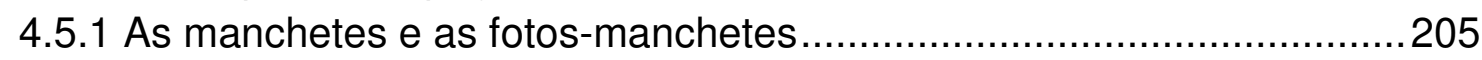

4.5.2 As fotos-legendas e a nota comentário relatado ................................208

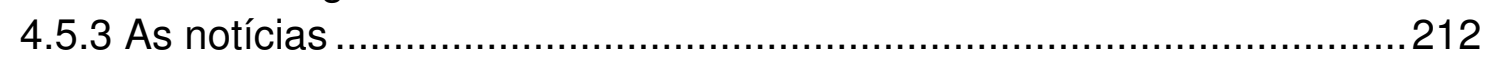

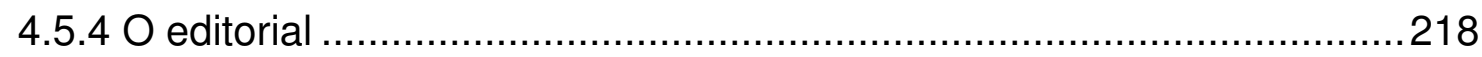

4.5.5 Os pathé e os ethé das primeiras páginas ………………………......221

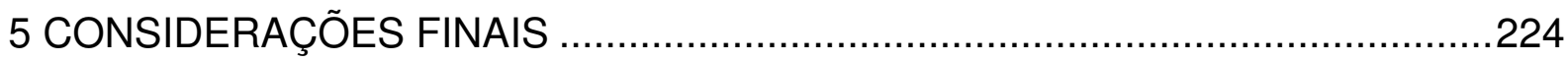

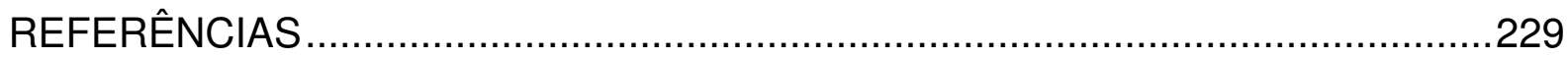

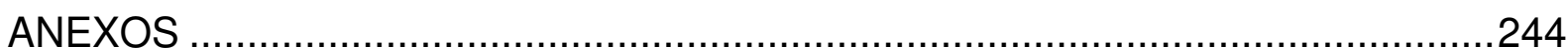

Anexo 1 - Primeira página do Correio da Manhã, edição de 02.04.1964 _...........244

Anexo 2 - Primeira página d'O Globo, edição de 02.04.1964 …......................245

Anexo 3 - Primeira página do Correio da Manhã, edição de 03.04.1964 .............246

Anexo 4 - Primeira página d'O Globo, edição de 03.04.1964 ...........................247

Anexo 5 - Primeira página do Correio da Manhã, edição de 10.04.1964 ............248

Anexo 6 - Primeira página d'O Globo, edição de 10.04.1964 ….........................249 


\section{INTRODUÇÃO}

Em nosso mestrado ${ }^{1}$, o trabalho incidiu sobre discursos enunciados a partir do campo de atividade político, tendo por objetivo o exame de três pronunciamentos parlamentares proferidos pouco antes da promulgação do Ato Institucional n. 5 . Na ocasião, a análise voltou-se para a construção dos ethé produzidos pelos discursos dos deputados federais Mário Covas Júnior (MDB-SP), Márcio Moreira Alves (MDBGB) e Geraldo Freire (ARENA-MG) durante a sessão parlamentar de 12 de dezembro de 1968. A pesquisa partiu da noção de ethos fundada na retórica aristotélica e integrada aos quadros da Análise do Discurso por Dominique Maingueneau, para, então, discutir alguns problemas em torno do ethos discursivo. $E$, com a finalidade de demonstrar como algumas categorias de análise podem ser mobilizadas em favor da depreensão do ethos discursivo, discorremos sobre a dêixis linguística e os procedimentos de embreagem e debreagem; as modalidades epistêmicas no processo de modalização; as formas do discurso citado; alguns procedimentos de argumentação; as cenas de enunciação, inclusive a cenografia. Os resultados obtidos nos permitiram vislumbrar a continuidade desse trabalho, uma vez que sentimos a necessidade de retomar nossa discussão sobre a noção de ethos, sobretudo no que tange à sua estreita relação com o pathos, bem como continuar deslindando as práticas discursivas referentes ao mais recente regime ditatorial instalado no Brasil.

Se, em nossa dissertação de mestrado, contemplamos discursos diretamente relacionados com o início do que se pode chamar de segunda parte da ditadura, pois foi a partir da promulgação do Al-5 que o regime intensificou brutalmente a censura à imprensa e a repressão política, nesta tese de doutorado, abarcaremos discursos pertencentes ao início da primeira parte da ditadura, configurando, portanto, a continuidade de uma pesquisa preocupada com a prática discursiva do regime autoritário brasileiro.

Assim, o objetivo geral desta pesquisa é analisar o discurso do Correio da Manhã e o discurso d'O Globo, focalizando a construção de suas identidades discursivas no seio da controversa relação polêmica estabelecida entre o que

\footnotetext{
${ }^{1}$ PIRIS, Eduardo Lopes. Elementos para um estudo do ethos numa polêmica parlamentar: análise dos pronunciamentos dos parlamentares que protagonizaram a sessão deliberativa de 12 de dezembro de 1968. (Dissertação de Mestrado). São Paulo, 2006.
} 
chamaremos de formação discursiva dita "revolucionária" e formação discursiva dita "antigolpista". É importante ressaltar que estamos adotando, desse modo, a referenciação discursiva reivindicada pelos atores discursivos pertencentes àquele contexto sócio-histórico, isso apesar de a obra basilar do brasilianista René Armand Dreifuss (1981), intitulada 1964: A conquista do Estado: ação política, poder e golpe de classe, não nos permita conceber o movimento político de $1^{\stackrel{0}{ }}$ de abril de 1964 diferentemente de outra coisa que não um golpe de estado.

A análise dos discursos do Correio da Manhã e d'O Globo sobre o movimento político de abril de 1964 passará pelo exame de um corpus constituído a partir das primeiras páginas de suas edições de 2, 3 e 10 de abril de 1964. Para alcançar tal objetivo, definimos os seguintes objetivos específicos: analisar o papel do pathos na construção do ethos discursivo de cada jornal, tratando de levantar quais são as emoções projetadas em seus discursos; a que razões essas emoções são atreladas; qual é o posicionamento dos atores discursivos que causam e que sofrem tais emoções; que tom enunciativo essas emoções imprimem no discurso jornalístico e como isso contribui para a construção da imagem de cada jornal.

No que toca ao objeto desta pesquisa, devemos dizer que o mesmo está longe de ser apenas o discurso do Correio da Manhã ou o discurso d'O Globo, tomados isoladamente, porque tal afirmação negligenciaria o que constitui a própria natureza constitutiva do discurso, a saber: a interdiscursividade. Trata-se, pois, de assumir a primazia do interdiscurso sobre o discurso, pressuposto teórico formulado, inicialmente, por Pêcheux (1997 [1975]) e Courtine (1981) e, posteriormente, retomado por Maingueneau (1997 [1987]) que implica, dentre outras coisas, na própria concepção do objeto de estudo dessa disciplina, o que significa dizer que, nesse quadro de Análise do Discurso:

[...] sustentar que o espaço pertinente para as regras é da ordem interdiscursiva consiste em propor ao analista o interdiscurso como objeto e fazê-lo apreender, de imediato, não uma formação discursiva, mas a interação entre formações discursivas. Isto implica que a identidade discursiva está construída na relação com o Outro (MAINGUENEAU, 1997 [1987], p. 119-120).

Estamos, efetivamente, diante de um recorte metodológico, o qual, segundo Maingueneau, resulta no espaço discursivo: uma abstração necessária ao trabalho do analista, a qual consiste num subconjunto de formações discursivas pertinente à proposta de análise e eleito no interior de um campo discursivo. 
Sobre isso, é conveniente dizer que a noção de interdiscurso é reformulada por Maingueneau (2007 [1984]) de tal maneira que três noções the são complementares, a saber: universo, campo e espaço discursivos. Para o autor, o universo discursivo abrange um conjunto vasto de formações discursivas que interagem em uma determinada conjuntura. Já o campo discursivo refere-se ao conjunto de formações discursivas que se encontram em concorrência, que se delimitam em uma determinada região do universo discursivo, tendo-se o cuidado de observar que a ideia de concorrência abarca não apenas o enfrentamento, como também a aliança e a neutralidade aparente; ademais, "é no interior do campo discursivo que se constitui um discurso" (p. 36).

Nesse contexto, o que podemos chamar de fechamento ou de fronteira de uma formação discursiva não se caracteriza como algo estanque, mas como algo instável, uma vez que a identidade de uma formação discursiva somente se constrói na relação com o Outro. A esse respeito, apoiando-se em Maingueneau (2007 [1984]), Gregolin (2000), explica que:

Os discursos não são entidades homogêneas nem completamente visíveis; em sua gênese, eles não se constituem independentemente uns dos outros para serem em seguida postos em relação, mas se formam de maneira regrada no interior do interdiscurso (GREGOLIN, 2000, p. 20).

Assim, é com base no primado do interdiscurso sobre o discurso que podemos conceber que o discurso dito "revolucionário" somente se sustenta graças ao discurso dito "antigolpista", e vice-versa, ou seja, um só existe em decorrência do outro. Isso não quer dizer que a natureza da constituição discursiva ou da gênese dos discursos caracterize-se pela pacífica negociação entre os discursos. De maneira figurada, Gregolin (2000) define bem o que ocorre nesse processo, ao dizer que "o interdiscurso [...] é, ao mesmo tempo, uma região de confronto de sentidos em que idéias contrárias se digladiam" (p. 23).

Isso quer dizer que a interdiscursividade caracteriza-se não pela simples reaparição de fragmentos discursivos num outro discurso, mas sim pela elaboração de um discurso sobre outros discursos, pois ela é o lugar do já-dito e também do não-dito; do esquecido e do proibido; é o lugar da dispersão de posições possíveis de ser assumidas por um sujeito (FOUCAULT, 2003 [1971]). 
Inspirado nesses postulados de Michel Foucault, Maingueneau (2007 [1984]) formula a primazia do interdiscurso sobre o discurso da seguinte maneira:

\begin{abstract}
A formação discursiva, ao delimitar a zona do dizível legítimo, atribuiria por isso mesmo ao Outro a zona do interdito, isto é, do dizível errado (p. 39).

O Outro circunscreve, pois, justamente, o dizível insuportável sobre cujo interdito se constituiu o discurso; por conseguinte, não há necessidade de dizer, a cada enunciação, que ele não admite esse Outro, que ele exclui pelo simples fato de seu próprio dizer (p. 40).
\end{abstract}

É importante sublinhar que o interdiscurso constitui o discurso não apenas por meio de marcas deixadas, explicita ou implicitamente, na materialidade discursiva. É nesse sentido que Brandão (2004, p. 93) diz que "a relação com o Outro deve ser percebida, portanto, independentemente de qualquer forma de alteridade marcada".

É nessa perspectiva que podemos entender que o cenário político brasileiro em 1964, embora fosse composto por diversas tendências partidárias representantes dos interesses dos vários setores sócio-econômicos estabelecidos no país, foi discursivamente construído sobre o eixo axiológico "comunismo versus democracia", polarizando e escamoteando os valores que estavam na essência dos discursos dos diversos grupos de interesses que disputavam o poder.

A construção da identidade do que estamos chamando de formação discursiva "revolucionária" e de formação discursiva "antigolpista" apoia-se num sistema de valores (que comporta elementos estereotipados) produzido por uma série de discursos em torno da Guerra Fria, em que, grosso modo, de um lado, reuniam-se esforços para promover uma imagem positiva do modo de vida americano, capitalista, em detrimento do modo de vida soviético, comunista; de outro lado, promovia-se a imagem positiva das conquistas sociais vividas pelo bloco comunista, em detrimento da desigualdade social vivida no bloco capitalista.

É preciso relembrar que, após o término da II Guerra Mundial, o cenário político internacional ficou polarizado entre os Estados Unidos da América (EUA) e a União das Repúblicas Socialistas Soviéticas (URSS), que, temendo perder o domínio político e econômico que haviam conquistado, se envolveram numa corrida armamentista, financiaram guerras civis e interferiram em governos de diversos países. Os Estados Unidos lançaram uma ofensiva anticomunista em todo 0 continente americano, com o objetivo de coibir medidas que, semelhantemente às 
adotadas por Fidel Castro (nacionalização de empresas norte-americanas, aproximação com URSS, entre outras), contrariavam seus interesses.

Essa breve explanação sobre o objeto desta pesquisa já nos permite dizer que um de nossos problemas é atribuir a esse objeto contornos que o tornem, de algum modo, menos difuso e mais preciso. Senão como abordá-lo? Impõe-se, portanto, uma questão de metodologia.

Ao retomar a tese da "ilusão de centralidade do sujeito" preconizada por Pêcheux (1997), Jacqueline Authier-Revuz (2004 [1982]) defende que o discurso é construído de modo que o sujeito pareça ser o centro do qual emanaria todo o controle sobre os sentidos e suas intenções, ocultando de alguma forma essa dispersão à qual se refere Foucault (2003 [1971]). E é essa ilusão de centralidade do discurso e do sujeito que oferece contornos mais precisos à identidade de um discurso.

É por essa razão que uma das questões centrais desta pesquisa é averiguar a identidade discursiva de cada jornal, considerando neles a presença - em menor ou em maior grau - dos discursos "revolucionário" e "antigolpista". É preciso notar que não se está analisando o discurso de políticos ditos "revolucionários" ou de políticos ditos "antigolpistas", mas sim de jornais que dialogam com esses discursos constituídos em relação polêmica controversa, ao mesmo tempo em que se pretendem apartidários e comprometidos apenas com a informação.

Assim, é interessante notar que a concorrência entre jornais se dá de forma diferente daquela que ocorre entre políticos numa disputa eleitoral. A estes não basta construir uma imagem favorável de si a seu eleitor, é preciso, de um modo ou de outro, desqualificar a imagem de seu adversário político para desaboná-lo perante seu eleitorado. Já o sucesso ou o fracasso da empresa jornalística assentase muito mais sobre a credibilidade que o nome do jornal consegue construir durante sua existência do que a desqualificação do patrimônio ético de seu concorrente.

Essa credibilidade construída ao longo dos anos consolida no mercado da informação uma determinada imagem de cada jornal e reforça sobremaneira a ilusão de centralidade do sujeito discursivo. Desse modo, impõe-se a esta pesquisa toda a problemática em torno do ethos discursivo, sobre a qual faremos uma breve explanação, a título introdutório.

O ethos associa-se à imagem que o enunciador oferece de si no discurso, 0 que não corresponde a qualquer opinião prévia que se tenha sobre sua pessoa, 
enquanto ser ontológico (cf. Barthes, 1975; Declercq, 1992; Fiorin, 2004; Maingueneau, 2005). E essa definição inicial de ethos coloca à pesquisa uma questão específica, uma vez que estamos nos propondo a depreender o ethos de duas empresas jornalísticas. A problemática colocada incide sobre o tipo de enunciador, pois não estamos analisando a imagem humana de dois indivíduos, políticos ou jornalistas, mas a imagem humanizada de duas empresas.

No discurso jornalístico, o ethos aparece não só como meio de adesão do público-leitor a um ponto de vista do jornal, pois o ethos, ao compreender o modo de dizer de um veículo de imprensa, bem como o seu modo de ser e de se comportar na esfera de atividade jornalística, cumpre também o papel de legitimar a enunciação de seu discurso como pertencente a um dado posicionamento discursivo.

Nesse aspecto, é exemplar como o Correio da Manhã e O Globo, em seus editoriais de 2 de abril de 1964, mostram-se favoráveis à derrubada de João Goulart, sem, porém, inscreverem seus discursos numa mesma formação discursiva. 0 primeiro constrói o ethos de um jornal participativo, captando, assim, o imaginário do leitor que deve participar dos fatos políticos e defender seu país. Constrói-se, nesse discurso, um ethos participativo, ao mesmo tempo em que constrói um anti-ethos não-participativo, oferecendo ao leitor uma relação de antagonismo favorável à incorporação do ethos. A incorporação é esse processo em que o coenunciador se vê como membro de "uma comunidade imaginária dos que aderem a um mesmo discurso" (MAINGUENEAU, 2005, p. 73). E, considerando a relação polêmica entre o discurso dito "revolucionário" e o discurso dito "antigolpista", esse anti-ethos politicamente não-participativo oferecido ao leitor do Correio da Manhã é associado àqueles que apenas assistem à tomada do poder pelos militares.

Em outras palavras, a incorporação consiste no papel que a imagem do corpo do enunciador (ethos) cumpre no processo persuasivo, mas não o corpo restrito a uma compleição física, e sim um corpo dotado de caráter e de reconhecimento sócio-cultural.

Por vezes, somos tentados a confundir a incorporação do ethos com os efeitos causados pelo pathos discursivo. Isso ocorre porque a incorporação também está ligada à identificação entre enunciador e coenunciador, às estratégias de criação da benevolência do enunciador para com o coenunciador. Então, para evitar tal confusão, é preciso, primeiramente, compreender a natureza do pathos retórico, 
cuja integração ao quadro teórico da Análise do Discurso irá nos propor algumas questões bem semelhantes àquelas do ethos.

É inegável que o pathos está fortemente associado ao coenunciador, no entanto difere-se da incorporação do ethos, pois recobre outro fenômeno discursivo mais específico nessa problemática. Em sua Retórica, Aristóteles define as paixões ${ }^{2}$ como "todos aqueles sentimentos que, causando mudança nas pessoas, fazem variar seus julgamentos" (ARISTÓTELES, 2000 [c.400 a.C], p. 5), porque "persuadese pela disposição dos ouvintes, quando estes são levados a sentir emoção por meio do discurso, pois os juízos que emitimos variam conforme sentimos tristeza ou alegria, amor ou ódio" (Id., 1998 [c.400 a.C], p. 49).

Atualmente, a noção de pathos e seus desdobramentos são objeto de estudo das mais diversas áreas do conhecimento e das várias tendências dentro das Ciências da Linguagem; por conseguinte, instaura-se uma grande dificuldade de estabilizar tal noção, a exemplo do que ocorre com a noção de ethos. E estabilizar, aqui, significa definir minimamente uma noção em um quadro teórico de modo que seja possível operar com ela, e não encerrar a discussão sobre o assunto.

Se uma das questões desta pesquisa é analisar a construção discursiva do pathos no processo de interação entre enunciador e coenunciador, observando seu papel na produção do ethos no discurso jornalístico, é preciso superar as perspectivas de análise que abordam as emoções somente como efeito que o discurso causa no destinatário da enunciação, ou seja, transpor esse viés dicotômico, apreendendo ethos e pathos de uma só vez.

Ao lado dessas questões de ordem teórica, existem também as questões de ordem metodológica, que se condensam na seguinte pergunta: "como depreender o ethos e o pathos?". Em nosso mestrado, esforçamo-nos para descrever o ethos com base em elementos linguístico-discursivos, tais como a dêixis linguística, a modalização, o discurso citado, os procedimentos de argumentação; as cenas de enunciação e a cenografia. Tentamos, naquele momento, mostrar que o analista deve se afastar de perspectivas subjetivas, para apurar de forma criteriosa os traços constituintes do ethos discursivo. Neste trabalho, iremos nos dedicar aos elementos de construção do pathos discursivo e como as emoções influenciam a qualidade de

\footnotetext{
${ }^{2}$ Plebe (1978, p. 42) adverte que a tradução de pathos por "paixão" deve ser entendida de forma aproximada, já que pathos "não é 'paixão' no puro sentido de uma inflamada emoção, mas é o mundo todo da irracionalidade emocional".
} 
ethos que é produzido no discurso jornalístico, concentrando-nos na formulação da noção de cenário passional, a qual servirá de base para depreensão do pathos.

Uma última questão coloca-se, ainda, a esta pesquisa. Uma vez que constituímos o corpus da pesquisa com base nas primeiras páginas do Correio da Manhã e d'O Globo, o exame do ethos e do pathos deve ser encaminhado com base não apenas na análise do discurso verbal, mas também no discurso gráfico-visual das empresas jornalísticas.

Dessa forma, será necessário compreender a primeira página como um gênero do discurso, ou melhor, como um hipergênero discursivo, e tentar responder às seguintes questões: (1) como a inter-relação dos gêneros jornalísticos no hipergênero "primeira página" contribui para a construção do sentido da página como um todo e (2) como as cenas de enunciação criadas pelos gêneros jornalísticos e pelo hipergênero "primeira página" captam o imaginário do leitor e, a partir disso, constroem os efeitos de identificação entre jornal e leitor.

Partimos, portanto, do pressuposto de que o estudo do ethos e do pathos passa também pela compreensão da primeira página como um hipergênero discursivo.

De modo geral, é importante que esta pesquisa dê conta das questões aqui levantadas no sentido de que, ainda, é preciso aparar algumas arestas no que diz respeito a concepções discutíveis apresentadas sobre o ethos em trabalhos ${ }^{3}$ situados na Análise do Discurso que se utilizam dessa noção originalmente retórica. A nossa inquietação quanto ao uso plural da noção de ethos deve-se ao fato de que, por vezes, o ethos é associado a outras instâncias subjetivas do discurso que não a do enunciador de seu próprio discurso; o ethos é confundido com a ideia de estereótipo, quando se diz "o ethos professoral de x", o "ethos jornalístico", o "ethos masculino" como se houvesse no mundo apenas um modo de ser professor, de ser jornalista, de ser homem; o ethos é restringido à noção de estilo, quando se pronuncia a máxima "ethos é estilo". De maneira alguma queremos dizer que o ethos não tenha suas relações com a imagem prévia do enunciador, com o estereótipo, com o estilo, entretanto, se assumirmos que o ethos se equivale a todas essas outras noções, parece-nos lícito indagar sobre a natureza e a especificidade do

${ }^{3}$ Os trabalhos de Maingueneau (1997, 2001), os artigos reunidos por Ruth Amossy (2005) e publicados sob o título de "Imagens de si no discurso: a construção do ethos", bem como aqueles organizados por Ana Raquel Motta e Luciana Salgado (2008) sob o título Ethos discursivo. 
ethos, ou seja, "afinal, o que é o ethos?". Assim, é por essas razões que julgamos importante retomar, nesta tese, a questão do ethos.

Já, no que concerne ao pathos, a relevância desta pesquisa está justamente no enfoque que ela propõe dar a essa noção originalmente retórica: o da Argumentação na Análise do Discurso. De fato, o tratamento específico e vertical das emoções vem ocupando lugar de destaque no seio das Ciências da Linguagem, haja vista as coletâneas organizadas em torno do assunto (cf. Plantin et al, 2000; Machado et al, 2007; Mendes et al, 2010), os trabalhos de Patrick Charaudeau (2007b, 2010 [2000]) e a vasta obra de Christian Plantin (1997, 1999, 2000, 2003, 2004, 2010 [1998], 2011).

Longe de negligenciar a contribuição desses trabalhos, é preciso, contudo, ter em mente que as abordagens propostas por todos esses pesquisadores não visam a conceber as emoções dentro da materialidade linguística e histórica do discurso. Quanto a isso, Ida Lúcia Machado (2007) nos ajuda a situar a perspectiva de trabalho de Charaudeau, ao afirmar o caráter comunicacional que o autor, numa visada Semiolinguística, atribui às emoções no discurso:

[...] as emoções não são causadas apenas pelas pulsões, pelo irracional ou por aquilo que não se pode controlar: elas têm um caráter social, revelado pelas trocas que indivíduos estabelecem entre si, no âmbito da comunicação (MACHADO, 2007, p. 169).

Outra corrente muito expressiva que vem tratando das emoções no discurso é aquela da Teoria da Argumentação, na qual se destacam, especificamente, as pesquisas dirigidas por Plantin. Basicamente, seu trabalho esforça-se para construir um método de análise argumentativa das emoções manifestadas no enunciado.

Independentemente da multiplicidade dos enfoques teóricos, todas essas pesquisas oferecem sua contribuição para o entendimento da dimensão emocional da linguagem e a compreensão dos procedimentos linguísticos, enunciativos, retóricos, argumentativos e discursivos de construção da emoção, de modo que tanto os estudos sobre o discurso, quanto os estudos sobre argumentação podem recorrer a alguns desses aportes teóricos, para - como neste nosso trabalho refletir sobre os efeitos de sentido relacionados às emoções no discurso, não apenas considerando o seu papel na interação comunicacional e na argumentação, mas também compreendendo as emoções como elemento constitutivo da produção discursiva em seu contexto sócio-histórico. 
Acreditamos, ainda, que a relevância deste trabalho diz respeito não só às questões teóricas suscitadas por nós nesta introdução, pois esta pesquisa, ao estudar a produção discursiva da imprensa escrita sobre o movimento político de 1964, volta sua atenção para uma série de acontecimentos que simbolizam o início de um período traumático da história política do Brasil.

Não se pode negar que o uso da violência e da tortura consiste no aspecto mais terrível e vergonhoso de toda a campanha repressiva do período ditatorial, no entanto também é preciso ter em conta que, ao lado dessa ação deliberadamente celerada, desenvolveu-se, na esteira do processo de desestabilização do governo de João Goulart, uma prática discursiva empenhada em justificar o putsch e desqualificar a resistência subsistente ${ }^{4}$. Nesse sentido, é importante que haja produção acadêmica sobre a construção da hegemonia do discurso do regime militar: discurso este que sustentou um regime de exceção e o manteve no poder por vinte e um anos. Trata-se, pois, de reconhecer não só a importância, como também a necessidade de compreender os processos de construção do discurso de legitimação e estabelecimento de um novo regime, assim como os de sua resistência.

Estudiosos da Análise do Discurso e também de outras disciplinas das Ciências Humanas examinaram as causas e as consequências do Golpe de 64. Podemos mencionar uma breve relação de notáveis trabalhos, tais como os dos historiadores Thomas Elliot Skidmore ${ }^{5}$ (1975; 1988), René Dreifuss ${ }^{6}$ (1981), Nelson Werneck Sodré $^{7}$ (1984) e Maria Aparecida de Aquino ${ }^{8}$ (1999); dos sociólogos e cientistas políticos Florestan Fernandes ${ }^{9}$ (1986) e Moniz Luiz Alberto Bandeira ${ }^{10}$ (1997); do jornalista Bernardo Kucinski ${ }^{11}$ (1991); dos analistas do discurso José Luiz

\footnotetext{
${ }^{4}$ Lembremos de como a política federal para as áreas da economia e da infra-estrutura fora ampla e favoravelmente justificada pelos discursos políticos pronunciados pelos Poderes Executivo e Legislativo, promovida pelas campanhas publicitárias oficiais e noticiada pelos mais variados órgãos de imprensa.

${ }^{5}$ Brasil: De Getúlio Vargas a Castelo Branco, 1930-1964 e Brasil: de Castelo a Tancredo, 1964-1985.

${ }^{6}$ 1964: A conquista do Estado.

${ }^{7}$ História da História nova.

${ }^{8}$ Censura, Imprensa, Estado Autoritário (1968-1978): o exercício cotidiano da dominação e da resistência O Estado de São Paulo e Movimento.

${ }^{9}$ Nova República?

${ }^{10}$ O golpe militar de 64 como fenômeno de política internacional.

${ }^{11}$ Jornalistas e Revolucionários: nos tempos da Imprensa Alternativa.
} 
Fiorin $^{12}$ (1988) e Freda Indursky ${ }^{13}$ (1997); entre outros pesquisadores não citados que dedicaram sua atenção a esse tema, correlacionando-o às suas respectivas áreas de estudo e contribuindo com publicações significativas.

Dessa forma, a contribuição desta pesquisa está, a nosso ver, em desvelar os discursos do Correio da Manhã e d'O Globo sobre a chamada "Revolução de Março", focalizando - tanto no discurso verbal manifestado nos gêneros jornalísticos, quanto no discurso gráfico-visual do layout das primeiras páginas - a produção dos efeitos de sentido passionais (pathos) e sua influência na construção da imagem do próprio jornal (o ethos), para, assim, identificar que tipo de pathos associa-se a quais posicionamentos discursivos localizados na polêmica entre "revolucionários" e "antigolpistas", e, com base nessa identificação, apreender que tipo de ethos legitima quais discursos sobre essa polêmica.

É por meio da análise do pathos e do ethos que a pesquisa busca revelar os efeitos de identificação entre o jornal e o seu leitor (estratégia de argumentação e elemento de construção da identidade discursiva do jornal), pois a compreensão do modo de dizer, de ser, de sentir, de se comportar e de se colocar no mundo jornalístico permite-nos desvelar a identidade discursiva dos dois jornais, bem como o papel que eles desempenharam na esfera de atividade jornalística naquele momento determinante para a história política do Brasil. Assim, neste trabalho, concentraremos nossas preocupações teóricas, esboçadas de maneira introdutória, na produção discursiva do Correio da Manhã e d'O Globo, dois jornais representativos naquela ocasião, sobretudo em razão de ambos pertencerem à chamada grande imprensa, com grande tiragem e circulação nacional.

Nesse contexto, é preciso considerar que o estudo do discurso do jornal, especialmente aquele voltado para a cobertura dos fatos políticos, suscita a questão da relação entre o discurso jornalístico e discurso político.

Se considerarmos que o homem é um animal político (cf. Aristóteles), teremos que a política se faz plenamente presente nos discursos dos mais variados campos de atividade humana, inclusive o midiático. Todavia, podemos considerar, também, que o político pertence a um domínio bem específico da atividade humana, o que nos levaria a dizer que o discurso político circularia tão somente em instituições de

\footnotetext{
${ }^{12}$ O regime de 1964: discurso e ideologia.

${ }^{13} \mathrm{~A}$ fala dos quartéis e outras vozes.
} 
poder como a Presidência da República, a Câmara Federal, o Senado, as Assembleias Legislativas etc. Enfim, antes de compreender a relação entre mídia e política, é preciso definir o que é o político.

William Menezes (2004), ao tratar da Análise do Discurso e do discurso político, defende uma nova concepção de política em oposição a duas tradições que remontam à Antiguidade, a saber: uma "restrita" e outra "ampla demais". A primeira, introduzida por Platão, concebe o discurso político como uma atividade exclusiva de especialistas da política. A segunda, apontada por Protágoras e Górgias, "pretende situar todo o conjunto da discursividade social como discurso político" (MENEZES, 2004, p. 248). O autor, inspirado na Microfísica do poder, de Foucault, entende que a noção de política pode ser alargada, sem, necessariamente, recobrir toda a atividade discursiva:

O Estado deixa de ser visto como órgão central e único de poder. Este é algo que se encontra em toda a sociedade; espalhado e articulado em malhas ou redes de micropoderes sociais (MENEZES, 2004, p. 249).

É interessante notar que, ao negar a identificação do poder e da política com os Aparelhos de Estado, na concepção althusseriana, Menezes (2004) propõe que se localize os diversos lugares de realização da política (p. 250), afastando-se de uma generalização do tipo "tudo é poder, logo tudo é política", para pensar "o discurso político como atividade de sujeitos nos diferentes espaços estruturais de produção e de manifestação deste discurso" (p. 250). Desse ponto de vista, podemos dizer que o discurso jornalístico afigura-se como um desses espaços estruturais de emergência do discurso político.

Recuperando um trabalho de Simone Bonnafous (1999), Menezes (2004) acena para esse problema de fronteira discursiva entre o político e o midiático, afirmando que "uma consideração sobre os gêneros do discurso político precisa levar em conta que, atualmente, torna-se muito difícil falar na existência deste campo sem percebê-lo como um fenômeno midiático" (p. 255).

Com base nessas reflexões, podemos dizer que há um apagamento das fronteiras entre o discurso político e o discurso jornalístico, sobretudo quando se trata do jornalismo político. De acordo com Roberto Seabra (2006, p. 138), o papel do jornalismo político na sociedade resume-se em três grandes funções: (1) informar o cidadão; (2) formar opinião garantindo a pluralidade de ideias; (3) fiscalizar o poder protegendo o cidadão contra seus abusos. E o autor propõe, nesse estudo, a 
seguinte indagação: "Como fiscalizar com isenção e eficiência se não há qualidade na informação que se oferece e não se garante a pluralidade de opiniões divergentes?" (SEABRA, 2006, p. 138). Antes de qualquer opinião divergente, esse questionamento de Seabra (2006) pode ser tranquilamente reforçado se recuperarmos o que Dreifuss (1981) afirma a respeito do papel da imprensa na campanha de desestabilização do governo João Goulart entre 1962 e 1964.

Fazer política fora dos quadros da governança é participar dos fatos políticos, manifestando a opinião a respeito desses mesmos fatos e, consequentemente, formando a opinião pública, que tem o seu poder de influência nas decisões políticas dentro dos quadros da governança. Nesse sentido, ao identificar os elementos da argumentação no discurso jornalístico, Lineide Salvador Mosca (2007b) traz uma reflexão muito interessante sobre o papel do jornal na construção da opinião, a qual, na ótica da autora, se constrói sobre o espaço tensivo da controvérsia, o dissenso:

\footnotetext{
Uma vez que a mídia ocupa hoje lugar importante na vida das pessoas, não de forma única e absoluta, mas fermentadora de opiniões, é impossível não reconhecer a sua influência nesse papel. No jornal, por exemplo, atrelado a interesses políticos, mercadológicos e corporativos, as suas posições se manifestam de modo implícito ou velado em todo o espaço disponível, pela priorização dos assuntos e pelo próprio favorecimento da diagramação, mas é nos cadernos especiais que a voz discordante da opinião tem a possibilidade de se manifestar (MOSCA, 2007b, p. 298).
}

Destacamos aqui o que Mosca (2007b) diz sobre a manifestação semiótica dos posicionamentos ideológicos próprios da tensão gerada pelos interesses diversos, pois as posições não estão marcadas apenas por meio da materialidade verbal, mas também na visual, que abrange as fotos-legendas, a diagramação, a paginação etc.

Trata-se, portanto, de um trabalho de pesquisa que se propõe a depreender os pathé e os ethé projetados pelas primeiras páginas de dois jornais de grande circulação nacional, a fim de verificar de que maneira essa dimensão subjetiva do discurso jornalístico legitima os posicionamentos de cada empresa perante 0 movimento político de 1964. 


\title{
2 QUADRO TEÓRICO-METODOLÓGICO
}

\subsection{Pressupostos teóricos para a análise da argumentação no discurso}

\subsubsection{Argumentação e Análise do Discurso}

Em sua Retórica, Aristóteles mostra que o tipo de raciocínio desenvolvido pela Retórica não é o demonstrativo, tal como o é na Dialética, mas sim o argumentativo, pois a arte retórica versa sobre aquilo que é provável, que é do âmbito da opinião, apresentando, como ponto de partida, premissas verossímeis ao invés de verdadeiras, o que não deve ser confundido com a busca pelo engodo, pela falácia. Isso é o que se pode entender a partir da leitura do próprio texto aristotélico, como se segue:

\begin{abstract}
Ora, sendo evidente que o método artístico é o que se refere às provas por persuasão e que a prova por persuasão é uma espécie de demonstração (pois somos persuadidos sobretudo quando entendemos que algo está demonstrado), que a demonstração retórica é o entimema e que este é, geralmente falando, a mais decisiva de todas as provas por persuasão; que, enfim, o entimema é uma espécie de silogismo, e que é do silogismo em todas as suas variantes que se ocupa a dialética, no seu todo ou nalguma das suas partes, é igualmente evidente que quem melhor puder teorizar sobre as premissas - do que e como se produz um silogismo - também será o mais hábil em entimemas, porque sabe a que matérias se aplica o entimema e que diferenças este tem dos silogismos lógicos. Pois é próprio de uma mesma faculdade discernir o verdadeiro e o verossímil, já que os homens têm uma inclinação natural para a verdade e a maior parte das vezes a alcançam. E por isso, ser capaz de discernir sobre o plausível é ser igualmente capaz de discernir sobre a verdade (ARISTÓTELES, 1998 [c.400 a.C], p. 46).
\end{abstract}

A retórica é, portanto, definida por Aristóteles como "a capacidade de descobrir o que é adequado a cada caso com o fim [de] persuadir" (p. 48). Todavia é interessante observar como os estudiosos da retórica divergem em suas opiniões sobre o que vem a ser a própria natureza da retórica. Plebe \& Pietro (1992) dedicam um capítulo inteiro de seu Manual de Retórica para desconstruir o que eles chamam de "o mito da argumentação". Começam por apontar o que seria uma contradição na obra de Perelman, acusando-o de "fazer o mundo da retórica deslizar do plano lógico-filosófico para o plano meramente sócio-psicológico" (p. 106) e, ainda, que: 
Perelman constrói toda a técnica da argumentação visando ao que chama de "contato das mentes" ${ }^{\text {", }}$ o qual lhe assegura a meta de persuasão. Mas a persuasão e o contato das mentes são, na realidade, uma finalidade secundária ante o objetivo mais ilustre que, desde as suas origens, a retórica se impôs: a invenção e o desenvolvimento dos conceitos (p. 108).

Entretanto, o que os autores do Manual de Retórica apontam como sendo um equívoco de Perelman é, justamente, o que nos parece ter sido a pedra de toque desse processo de revitalização da retórica na Modernidade: a restauração da dimensão subjetiva nos estudos retóricos. Nossa questão não é discutir sobre o caráter mais ilustre ou menos ilustre dos objetivos da retórica clássica, mas sim sublinhar que a arte retórica fora orientada, desde sua origem, em razão de uma intervenção concreta do indivíduo em seu meio social, por meio da linguagem, em que não se concebe a abordagem da invenção alijada de um "para quem inventar" e de um "para que inventar", ou seja, da importância do papel do orador e do seu auditório na atividade argumentativa ${ }^{15}$.

Assim, diferentemente de Plebe \& Pietro (1992), Plantin (1996, p. 10) entende que o Tratado da argumentação, de Perelman \& Olbrechts-Tyteca (1996 [1958]), e Os usos do argumento, de Toulmin (2006 [1958]), - duas obras que recolocaram em cena os estudos retóricos, até então em desprestígio, embora apresentem horizontes teóricos distintos - são dotadas de um mesmo objetivo, pois seus autores "pesquisam, no pensamento argumentativo, um meio de fundar uma racionalidade específica, em ação das relações humanas"16.

Podemos dizer, então, que os trabalhos de Perelman \& Olbrechts-Tyteca (1996 [1958]) e de Toulmin (2006 [1958]) marcam o início da revitalização da abordagem da argumentação fundada sobre o verossímil, ou seja, uma argumentação que busca convencer seu auditório por meio da negociação e que destaca a dimensão intersubjetiva do discurso. Sob esse aspecto, Mosca (2007b, p. 297) esclarece que:

\footnotetext{
${ }^{14}$ Referência ao termo "contato dos espíritos", tal como consagrado pela tradução do Tratado da Argumentação.

${ }^{15}$ Conforme Ruth Amossy (2011, p. 129 [2008, p. 2]), "a retórica clássica, definida como a arte de persuadir - [é], nesse sentido, sinônimo de argumentação".

${ }^{16}$ Tradução nossa. No original: "Ils recherchent dans la pensée argumentative un moyen de fonder une racionalité spécifique, à l'œuvre dans les affaires humaines." (PLANTIN, 1996, p. 10).
} 
O terreno da argumentação parte dos lugares-comuns, das idéias partilhadas, enfim, da doxa, mas o seu campo específico não é o das certezas, e sim do que é suscetível de discordância, visto abarcar a diversidade de opinião e o dissenso, em torno do objeto de discussão.

A partir dessas duas obras, a argumentação despertou o interesse de estudiosos filiados a correntes teóricas diversas nem sempre convergentes. A multiplicidade dos enfoques acerca desse objeto de estudo levou, dentre tantas outras consequências, à polissemia do termo "argumentação". A esse respeito, Plantin (1996, p.18) alerta que há duas acepções bem distintas para o termo argumentação:

- Argumentação enquanto orientação dirigida a uma conclusão, em que se analisa a propriedade semântica da frase, considerada fora de contexto;

- Argumentação enquanto fato de discurso, associada à prática da linguagem em contexto.

Para ilustrar a distinção entre a abordagem da argumentação na língua e a abordagem da argumentação no discurso, retomemos o artigo de Maingueneau (2011 [1994]) intitulado "Argumentação e Análise do Discurso (Reflexões a partir da segunda Provincial)", em que critica um estudo de Oswald Ducrot (1971) consagrado à análise da argumentação da Segunda Provincial, escrita por Pascal em 1656.

Em linhas gerais, o autor da Provincial discute a posição dos dominicanos sobre a "graça suficiente", apresentando, portanto, três teses: a dos jesuítas, a dos jansenistas e a dos próprios dominicanos. O método de Ducrot (1971), segundo Maingueneau (2011 [1994], p. 75):

[...] consiste em mostrar que o raciocínio de Pascal se traduz com exatidão no formalismo do cálculo dos predicados, e que essa surpreendente tradução tornou-se possível por meio de uma interpretação lógicomatemática do adjetivo suficiente.

Maingueneau entende que, embora Ducrot aplique corretamente os cálculos de predicados e, com base nisso, conclua que Pascal cometera um erro, do ponto de vista da análise do discurso, o autor da Segunda Provincial utiliza-se de uma linguagem de não especialista, para criar a imagem de um homem de bom senso que dirige sua fala a outros homens de bom senso, o que caracteriza não um erro, mas o uso de um recurso argumentativo voltado à construção da identificação do autor com seu leitor. 
Em outras palavras, a análise argumentativa da Segunda Provincial deveria voltar-se não para os cálculos de predicados, mas sim para a compreensão da situação de enunciação da produção discursiva, do próprio gênero epistolar e do ethos discursivo. No ponto de vista de Maingueneau (2011 [1994], p. 71), trata-se de conceber a argumentação como uma dimensão do discurso, visto que:

[...] quando o analista do discurso se volta para a argumentação, não é com a intenção de estabelecer o modelo dos processos de validação, mas de relacioná-los a um gênero do discurso histórica e socialmente situado.

Numa perspectiva de trabalho próxima a de Maingueneau, Ruth Amossy (2007, p. 123) também situa a argumentação na dimensão sócio-histórica do discurso, pois defende uma perspectiva de estudo da argumentação no discurso "que relaciona a fala a um lugar social e a instâncias institucionais". Para a pesquisadora israelense, a argumentação:

[...] depende das possibilidades da língua e das condições sociais e institucionais que determinam parcialmente o sujeito, fora dos quais a orientação ou a dimensão argumentativa do discurso não pode ser apreendida com discernimento (op. cit., p. 128).

E, mais recentemente, Amossy (2011 [2008], p. 133), ao oferecer novos elementos para a abordagem da argumentação no discurso, distingue duas maneiras de considerar a argumentação, afirmando que:

Essa atenta abordagem ao eixo de comunicação e interação (atual ou virtual) entre os participantes da troca permite conferir à análise argumentativa sua dimensão institucional e social. Passa-se, então, do domínio dos universais, que implica a retórica orientada pelo logos como razão atemporal, ao domínio do social em sua relatividade e suas variações históricas e culturais.

Do exposto até aqui, é possível dizer que a análise da argumentação, tal como é concebida por Maingueneau, Plantin e Amossy, convoca aportes teóricos de outras disciplinas, mostrando-se propensa a articulações com outros quadros, especialmente os da Teoria da Enunciação, da Pragmática e da própria Análise do Discurso.

Bem entendido que a análise da argumentação no discurso não prescinde das questões da enunciação, vale recorrer às considerações tecidas por Maingueneau (2011 [1994]), Plantin (1996) e Amossy (2011 [2008]) sobre o lugar da 
enunciação nessa abordagem teórica, ressaltando o caráter concreto da argumentação. Dessa maneira, Maingueneau (2011 [1994], p. 85), afirma que:

Não poderíamos, portanto, estabelecer o texto como um conteúdo independente das condições de sua enunciação, nem reduzir a argumentação ao estatuto de meio a serviço de uma persuasão.

Por sua vez, Plantin (1996, p. 18) afirma que "toda fala é necessariamente argumentativa. É um resultado concreto da enunciação em situação"17.

E, em um recente artigo, Amossy (2011 [2008], p. 133) também aponta a relação entre argumentação e enunciação, associando os participantes da enunciação à concepção de auditório postulada por Perelman da seguinte maneira:

A argumentação se situa no quadro de um dispositivo de enunciação em que o locutor deve adaptar-se ao seu alocutário, ou mais exatamente, à imagem que ele projetou (nos termos de Perelman, o auditório é sempre uma construção do orador).

Ela supõe, também, que se tenha em conta a situação concreta de enunciação: quem fala a quem, em que relação de lugares, qual é o estatuto de cada um dos participantes, quais são as circunstâncias exatas da troca, quais são o momento e o lugar em que ela ocorre.

Outro ponto relevante, nessa perspectiva de análise, diz respeito a dois aspectos da argumentação: um, que seria constitutivo da linguagem e inerente a qualquer tipo de produção discursiva; outro, que caracterizaria apenas os discursos explicitamente argumentativos. Segundo a autora, o primeiro aspecto da argumentação seria recoberto pela ideia de "dimensão argumentativa", enquanto o segundo, pela ideia de "intenção argumentativa". Dessa forma, Amossy (2006, p. 33) ilustra essa distinção, mostrando que:

Um discurso de defesa tem uma clara intenção argumentativa: ele apresenta como objetivo principal fazer admitir a inocência do indiciado que o advogado tem por tarefa de defender, ou de apresentar circunstâncias atenuantes que diminuirão sua pena. Uma descrição jornalística ou romanesca, ao contrário, pode ter antes uma dimensão do que uma vontade argumentativa $^{18}$.

\footnotetext{
17 Tradução nossa. No original: "Toute parole est nécessairement argumentative. C'est un résultat concret de l'énonciation en situation" (PLANTIN, 1996, p. 18).

${ }^{18}$ Tradução nossa. No original: "Une plaidoirie a une nette visée argumentative: elle se donne comme objectif premier de faire admettre l'innocence de l'inculpé que l'avocat a pour tâche de défendre, ou de présenter des circonstances atténuantes qui diminueront sa peine. Une description journalistique ou romanesque, par contre, peut avoir une dimension plutôt qu'une volonté argumentative" (AMOSSY, 2006, p. 33).
} 
Essa distinção deve ser considerada, sobretudo, para orientar os procedimentos de análise da argumentação no discurso, pois as características da materialidade a ser examinada acabam exigindo do analista a eleição de determinadas categorias de análise e não de outras. Neste trabalho, por exemplo, a proposta é apontar os efeitos de sentido de identificação entre jornal e leitor construídos pelo layout da primeira página jornalística por meio da análise dos elementos de composição desse hipergênero discursivo. Trata-se aqui de explorar, preferencialmente, a dimensão argumentativa de um discurso caracteristicamente informacional, e não as estratégias de argumentação de um tipo de discurso cuja finalidade primeira é o convencimento e a persuasão.

Graças aos desdobramentos propostos por Amossy é possível definir quais as categorias de análise da argumentação no discurso que se sobressaem em proveito da construção dos procedimentos teórico-metodológicos dessa abordagem. Assim, Amossy (2011 [2008]), ao afirmar que "a argumentação [...] não é o emprego de um raciocínio que se basta por si só, mas uma troca atual ou virtual - entre dois ou mais parceiros que pretendem influenciar um ao outro" (p. 133) delimita quais categorias interessam e não interessam à análise discursiva da argumentação.

Destacam-se, nessa abordagem, não "o silogismo, o entimema, a analogia" nem o "encadeamento de proposições lógicas", por exemplo, mas sim elementos da língua natural, tais como "o uso de conectores ou de dêiticos, [...] a pressuposição e o implícito, as marcas de estereotipia, a ambiguidade, a polissemia, a metáfora, a repetição, o ritmo" (AMOSSY, 2011 [2008], p. 132). Além disso, noções discursivas como a de gênero do discurso, de heterogeneidade, de ethos e de pathos são colocadas em foco por essa perspectiva de estudo da argumentação no discurso.

Dessa maneira, Amossy (2011 [2008]) coloca em evidência a importância dos gêneros discursivos na análise da argumentação no discurso, salientando que:

[...] a fala situa-se, necessariamente, no quadro de um gênero de discurso que ocupa um lugar particular num espaço social dado e que comporta seus objetivos, suas regras e suas próprias restrições (p. 133).

A consideração de um quadro genérico mostra a que ponto a arte de persuadir é determinada pelas regras e restrições do gênero do discurso em que está empregada (p. 139).

Considerando o conceito bakhtiniano de gênero de discurso, podemos dizer que, dentre essas regras e restrições determinadas pelo gênero discursivo 
mencionadas por Amossy, estão não apenas aquelas que dizem respeito ao estilo de linguagem e à temática esperados por determinado gênero, mas principalmente pelos efeitos de sentido que podem ser gerados pela construção composicional, ou seja, os efeitos produzidos pelo tipo de construção de conjunto, pelo tipo do acabamento desse conjunto, pelo tipo de relação do enunciador com os outros participantes da comunicação discursiva (os leitores e o discurso do outro) (BAKHTIN, 2003, p. 266).

A cena de enunciação instalada pelo gênero de discurso, a cena genérica, projeta no enunciado a relação que se estabelece entre os participantes da comunicação discursiva, ou seja, determina os lugares enunciativos que devem ser assumidos para a legitimação do discurso. Ademais, também a cena genérica impõe restrições sobre o modo de dizer, de modo que se afigura como fator de persuasão a negociação entre 0 modo de dizer do enunciador, no caso desta pesquisa 0 enunciador institucional jornal, e o modo de dizer esperado pelo gênero de discurso, neste caso os gêneros jornalísticos manchete, editorial, notícia, nota comentário relatado etc. e o hipergênero primeira página do jornal, mais especificamente os efeitos de sentido gerados a partir dessa negociação. E essa dimensão argumentativa do gênero do discurso remete, imediatamente, à construção do ethos discursivo.

Amossy (2011 [2008], p. 133) encampa, ainda, em sua proposta de análise da argumentação no discurso, a questão da heterogeneidade discursiva e da interdiscursividade, ressaltando o caráter essencial da heterogeneidade no discurso argumentativo:

É nesse quadro comunicacional e sócio-histórico que é preciso estudar de perto a maneira como a argumentação se inscreve, não somente na materialidade discursiva [...], mas também no interdiscurso.

[...] a heterogeneidade constitutiva é um dos fundamentos da fala argumentativa na medida em que esta, necessariamente, reage à palavra do outro, quer seja para retomá-la, modificá-la ou refutá-la.

Nesse sentido, a perspectiva de Amossy repercupe 0 trabalho de Maingueneau (1997 [1987], p. 125), quando este afirma que "o exercício da polêmica presume a partilha do mesmo campo discursivo", em que "é preciso desqualificar o adversário, porque ele é constituído exatamente do Mesmo que nós, mas deformado, invertido". 
Assim, é com base nesses pressupostos teóricos que nossas análises tentarão mostrar como os jornais constroem sua identidade discursiva por meio da negociação com o seu Outro e, a partir dos resultados obtidos, apreender os ethé do Correio da Manhã e d'O Globo.

Por fim, devemos ressaltar que Amossy reafirma a necessidade da integração das noções retóricas de pathos e de ethos pelos quadros teóricos das atuais disciplinas que se ocupam do discurso e da argumentação:

É nesse contexto, também, que é preciso retomar dois polos da retórica clássica, muitas vezes negligenciados pelas teorias da argumentação: o ethos, ou a construção da imagem de si no discurso (AMOSSY, 2005), e o pathos, ou a construção discursiva da emoção que o locutor pretende provocar em seu auditório (PLANTIN, 2000) (AMOSSY, 2011 [2008], p. 133134).

Fazendo eco aos postulados de Maingueneau e de Amossy, entendemos que o pathos e o ethos são noções privilegiadas nessa perspectiva de estudo que integra discurso e argumentação, pois, ao mesmo tempo em que se afiguram como categorias da dimensão subjetiva do discurso, trazem consigo - desde as suas origens na retórica clássica - sua natureza essencialmente argumentativa. Esse é o assunto a ser explorado na subseção seguinte. 


\subsubsection{0 ethos discursivo}

Em sua Retórica, Aristóteles define três espécies de provas artísticas de persuasão fornecidas pelo discurso, afirmando que "umas residem no carácter moral do orador; outras, no modo como se dispõe o ouvinte; e outras, no próprio discurso, pelo que este demonstra ou parece demonstrar" (ARISTÓTELES, 1998 [c.400 a.C], p. 49). Explica essa primeira prova da seguinte maneira:

Persuade-se pelo carácter quando o discurso é proferido de tal maneira que deixa a impressão de o orador ser digno de fé [e que] é, porém, necessário que esta confiança seja resultado do discurso e não de uma opinião prévia sobre o carácter do orador.

Já a segunda prova consiste na disposição dos ouvintes, ou seja, nas emoções que o discurso os leva a experimentar, ao passo que a terceira prova deriva do que é construído por meio do próprio raciocínio. Essas três espécies de provas técnicas ou artísticas de persuasão correspondem mais especificamente aos

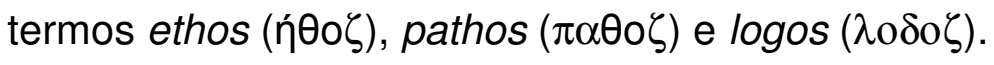

Armando Plebe (1978, p. 42) alerta que ethos pode ser traduzido por "caráter" apenas de forma aproximada, pois ethos é também atitude, costume e moralidade. Nesse sentido, Ekkehard Eggs (2005, p. 30) mostra que há "dois campos semânticos opostos ligados ao termo ethos: um, de sentido moral [...], engloba atitudes e virtudes como honestidade, benevolência ou equidade; outro, de sentido neutro ou 'objetivo' da héxis, reúne termos como hábitos, modos e costumes ou caráter".

Ao apresentar uma distinção entre as grafias êthos e éthos, Ferreira (2009, p. 1) nos mostra que o motivo dessa duplicidade de sentido em torno da palavra ethos deve-se mesmo a questões de tradução, todavia não se quer dizer que a opção por "caráter" ou por "costumes" deve ter surgido em razão de julgamentos equivocados dos tradutores, mas sim por existirem, realmente, duas palavras distintas que recobrem cada um desses termos traduzidos, a saber:

- $\tilde{\eta} \theta 0 \varsigma:$ com /e/ inicial longo significa "caráter" e "modo de ser";

- ËӨos: com /e/ inicial breve significa "hábito" ou "costume".

Neste fragmento oferecido pelo dicionário eletrônico da Perseus Digital Library, podemos notar a ocorrência dessas duas palavras numa mesma frase 


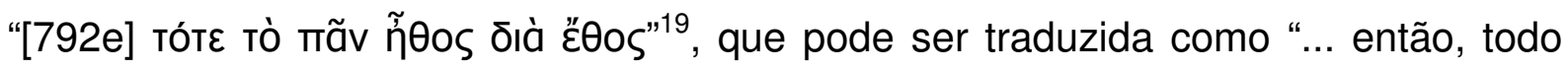
êthos é segundo um éthos", ou seja, "... todo caráter/modo de ser é segundo o hábito"20.

Isso nos mostra que o ethos retórico deve ser entendido como uma construção do discurso que pode compreender tanto a dimensão moral quanto a dimensão social do orador, em que não será necessariamente a própria honestidade do orador que lhe garantirá o sucesso persuasivo, mas sim a impressão que o seu discurso causar.

Em nosso mestrado (PIRIS, 2006), fundamentamo-nos em outros estudiosos da retórica aristotélica que corroboram esse ponto de vista sobre o ethos, tais como Roland Barthes (1975) e Gilles Declercq (1992). Retomando os comentários desses dois autores, temos que os ethé "são os traços de caráter que o tribuno deve mostrar ao auditório (pouco importa sua sinceridade) para causar boa impressão: são suas aparências" (BARTHES, 1975, p. 203), de modo que "o ethos deve ser compreendido como uma condição técnica e intrínseca do processo de persuasão, e não como uma qualidade moral e extrínseca que resulta da natureza do orador"21 (DECLERCQ, 1992, p.47). A esse respeito, apoiamo-nos também em Fiorin (2004, p. 120), o qual ressalta que "o éthos não se explicita no enunciado, mas na enunciação [...], ou seja, nas marcas da enunciação deixadas no enunciado", retomando a ideia aristotélica de que o ethos é uma construção do discurso, um efeito de sentido, e não algo dado a priori.

No que diz respeito à integração do ethos retórico ao quadro teórico da Análise do Discurso, é Maingueneau que vem abordando tal questão desde a sua Gênese dos discursos, publicada, originalmente, em 1984, quando o autor, embora já defendesse a tese de que o modo de enunciar é uma construção discursiva que legitima a enunciação do próprio discurso enunciado, ainda não empregava, propriamente, o termo ethos.

\footnotetext{
${ }^{19}$ Plato. Leges. In: BURNET, John (ed). Platonis Opera. Vol.5, Oxford: Clarendon Press, 1907. Disponível http://www.perseus.tufts.edu/hopper/text?doc=Perseus\%3Atext\%3A1999.01.0165\%3Abook\%3D7\%3 Asection\%3D792e.

${ }^{20}$ Agradecemos os esclarecimentos dados por Moisés Olímpio Ferreira no que diz respeito à tradução do texto grego usado para essa ilustração, bem como à diferença entre as grafias êthos e éthos.

${ }^{21}$ Tradução nossa. No original: "L'ethos doit donc se comprendre comme une condition technique et intrinsèque du processus de persuasion, et non comme une qualité morale et extrinsèque issue de la nature de l'orateur" (DECLERCQ, 1992, p. 47).
} 
Isso é o que podemos constatar na seguinte passagem:

Mas um discurso não é somente um certo conteúdo associado a uma dêixis e a um estatuto de enunciador e de destinatário, é também uma "maneira de dizer" específica, a que nós chamaremos um modo de enunciação (MAINGUENEAU, 2007 [1984], p. 94).

Todavia, é a partir da publicação de Novas Tendências em Análise do Discurso, cujo original é de 1987, que Maingueneau (1997 [1987], p. 45) começa a utilizar o termo ethos, inspirando-se na retórica aristotélica para aprimorar aquela sua ideia inicial recoberta pelo que ele chamou de modo de enunciação e, assim, integrar definitivamente a noção de ethos ao quadro teórico da Análise do Discurso. Vejamos, então, como o autor reformula sua teorização sobre a relação entre o discurso e o seu modo de enunciar:

Não basta falar de "lugares" ou de "dêixis"; a descrição dos aparelhos não
deve levar a esquecer que o discurso é inseparável daquilo que poderíamos
designar muito grosseiramente de uma "voz". Esta era, aliás, uma dimensão
bem conhecida da retórica antiga que entendia por ethé as propriedades
que os oradores se conferiam implicitamente, através de sua maneira de
dizer: não o que diziam a propósito deles mesmos, mas o que revelavam
pelo próprio modo de se expressarem.

Basicamente, a proposta de Maingueneau (1997 [1987], p. 46) consiste na ideia de que "o que é dito e o tom com que é dito são igualmente importantes e inseparáveis", ou seja, o analista traz à tona a problemática da "voz que habita a enunciação do texto", concebendo essa voz como "uma das dimensões da formação discursiva".

Para Maingueneau (1997 [1987], p. 46-47), os discursos, mesmo aqueles que se manifestam por meio de gêneros discursivos escritos, possuem um tom que "está necessariamente associado a um caráter e a uma corporalidade", corporalidade esta que "remete a uma representação do corpo do enunciador da formação discursiva".

Podemos dizer, portanto, que é a partir de Novas tendências em Análise do Discurso que Maingueneau integra a noção de ethos ao seu quadro teórico de Análise do Discurso. Em linhas gerais, podemos dizer que o ethos é uma noção discursiva que está associada à construção da imagem do orador por meio da produção discursiva, não correspondendo, portanto, a qualquer opinião prévia que se tenha sobre sua pessoa, embora - como iremos mostrar mais adiante - essa opinião prévia tenha o seu papel na construção do ethos. 
Em O contexto da obra literária, Maingueneau (2001 [1993], p. 139) retoma a questão do ethos, atribuindo-lhe contornos mais precisos dentro dos estudos discursivos. Entendemos que essa obra traz contribuições de grande relevância, dentre as quais podemos destacar a noção de "fiador", assim formulada pelo autor:

A instância que assume o tom de uma enunciação evidentemente não coincide com o autor efetivo da obra. [...]. Essa representação desempenha o papel de um fiador que se encarrega da responsabilidade do enunciado.

Portanto, ao afirmar que o ethos está associado à imagem do enunciador, não estamos dizendo que ambas as noções sejam equivalentes, porque a noção de ethos não se limita a recobrir a ideia que concerne à imagem do enunciador, mas sim remete à concepção de um fiador do discurso, aquele que garante o que é dito, que legitima seu discurso pelo seu modo de dizer.

Em seu artigo "Ethos, cenografia, incorporação", publicado na coletânea organizada por Amossy (2005 [1999]), Maingueneau (2005 [1999], p. 72) retoma, novamente, a questão do ethos e reafirma suas formulações sobre a noção do fiador do discurso. Para o autor, o 'termo 'tom' apresenta a vantagem de valer tanto para o escrito quanto para o oral: pode-se falar do 'tom de um livro", sendo que esse tom se afigura como uma vocalidade que implica o corpo do enunciador, mas não o corpo de um ser empírico, e sim uma corporalidade que emerge do discurso como "uma instância subjetiva encarnada que exerce o papel de fiador".

Nesse contexto teórico, é interessante notar como Maingueneau relaciona o ethos à estereotipia, pois, conforme o analista francês, esse corpo do enunciador, provido de tom, caráter e corporalidade, é o que garante a legitimidade ${ }^{22}$ do discurso, uma vez que suas qualidades apoiam-se em representações sociais, em estereótipos culturais valorizados positivamente ou negativamente por um dado grupo social. Vale acompanhar o raciocínio desenvolvido pelo autor do referido artigo:

Caráter e corporalidade do fiador apóiam-se, então, sobre um conjunto difuso de representações sociais valorizadas ou desvalorizadas, de estereótipos sobre os quais a enunciação se apóia e, por sua vez, contribui para reforçar ou transformar. Esses estereótipos culturais circulam nos registros mais diversos da produção semiótica de uma coletividade: livros de moral, teatro, pintura, escultura, cinema, publicidade [...] (op. cit., p. 72).

\footnotetext{
${ }^{22}$ A legitimidade de um discurso não se confunde com autoridade ou com prestígio social, mas tem a ver com a inscrição sócio-histórica do discurso a uma formação discursiva.
} 
Não obstante, Amossy (2005 [1999], p. 125-126) também entende que "a noção de estereótipo [...] desempenha papel essencial no estabelecimento do ethos", definindo o processo de estereotipagem como:

[...] a operação que consiste em pensar o real por meio de uma representação cultural preexistente, um esquema coletivo cristalizado. Assim, a comunidade avalia e percebe o indivíduo segundo um modelo préconstruído da categoria por ela difundida e no interior da qual ela o classifica.

É interessante notar que essa relação entre ethos e estereótipo pode suscitar inúmeras questões. Desse modo, podemos destacar que, ao circular nas várias esferas de produção discursiva de uma comunidade, um mesmo estereótipo pode apoiar a construção de vários ethé similares manifestados em diferentes tipos e gêneros discursivos, como em um pronunciamento parlamentar (discurso político) ou em um editorial de jornal (discurso jornalístico).

Podemos sublinhar também que essa relação entre ethos e estereótipo deságua no que se convencionou chamar de ethos prévio, noção que, para nós, parece colocar um problema, dependendo do ponto de vista teórico. Antes de tecer nossas considerações sobre essa questão, vejamos a seguinte apresentação feita por Amossy (2005 [1999], p. 125):

O recurso à noção de estereótipo [...] permite destacar uma dimensão importante do ethos, pouco estudada até agora, chamada ethos prévio: é a imagem que o auditório faz do locutor no momento em que este toma a palavra.

As análises do discurso praticadas por Maingueneau, Amossy e Haddad indicam por vias diversas a necessidade de considerar a posição do locutor como ser empírico no campo em que ele se situa (político, intelectual, literário ou outro).

Com base no pressuposto aristotélico de que o ethos é a imagem do orador construída por ele mesmo no momento da enunciação de seu próprio discurso (a redundância referencial aqui é proposital), podemos apontar dois problemas nos excertos supracitados.

Primeiramente, parece-nos pouco adequado o emprego do termo ethos prévio, mesmo que acompanhado desse qualificador "prévio", pois o que se pretende recobrir com tal termo é uma imagem construída (i) antes da enunciação do discurso e (ii) por outro ator que não o próprio orador ou enunciador. 
O segundo problema diz respeito a essa "necessidade de considerar a posição do locutor como ser empírico", tal como afirma Amossy, pois, para o exame do ethos, entendemos que o analista deve levar em conta essa imagem que o auditório detém do orador antes mesmo que ele enuncie seu discurso, desde que se compreenda que a análise incide não sobre os sujeitos empíricos, mas sim sobre as representações previamente construídas desses sujeitos.

Voltemos a nos concentrar sobre o problema do chamado ethos prévio, observando a formulação apresentada por Haddad (2005 [1999], p. 145):

É a relação entre o "ethos prévio" (a imagem preexistente do locutor) e o ethos discursivo (a imagem que ele constrói em seu discurso) que se encontra no centro desta análise. Trata-se de estudar as estratégias às quais o orador recorre para produzir uma impressão favorável de seu projeto argumentativo.

No entendimento de Haddad (2005 [1999]), cabe ao orador reelaborar os estereótipos que Ihe são desfavoráveis, baseando-se na "idéia que presumivelmente o auditório projeta dele" (p. 148). Podemos notar, nessa formulação, que Haddad parte do pressuposto de que há no orador uma intencionalidade de "corrigir" o seu ethos, ou seja, alterar o seu modo de dizer, o seu modo de ser e de se comportar no mundo. Nosso questionamento acerca dessa concepção de ethos prévio reside no fato de que o que o orador pode fazer é retratar-se perante seu auditório, reconsiderando certos pontos de vista julgados como não pertencentes ao conjunto de valores e de crenças daquele orador e de seu auditório, enfim de seu grupo social. E o orador faz essa retratação sem, necessariamente, alterar o seu ethos, o seu modo de enunciar, mas sim reformulando enunciados que foram mal recebidos por seu auditório.

Tomemos, por exemplo, o caso do ex-candidato às eleições presidenciais de 2006, Geraldo Alckmin, o qual disse, num debate ao vivo, que sua meta para a segurança seria de 3.000 homicídios por ano. Evidentemente, esse enunciado não foi bem recebido pelo público mais atento e serviu de "munição" às campanhas de seus adversários. Já, no debate seguinte, o candidato tucano corrigiu esse seu enunciado, dizendo que sua meta seria a de reduzir a taxa de homicídios de 6.000 para 3.000. Do ponto de vista argumentativo, o segundo enunciado apresentou efeito de eficácia mais positivo do que o primeiro, pois Alckmin deixa de ser o candidato que pretende que ocorram 3.000 homicídios, para ser o candidato que 
reduzirá pela metade essa taxa. O seu ethos de homem público sério, competente, capaz, porém, mantém-se o mesmo nos dois enunciados, porque o seu modo de enunciar, dominado pela convicção, independentemente do que ela diga, não se altera.

Podemos, então, entender essa imagem preexistente do locutor defendida por Haddad (2005 [1999]) como um conjunto de predicados (sejam eles positivos ou negativos) atribuídos à imagem do enunciador, que, na enunciação de seu próprio discurso, atualizam uma memória discursiva ${ }^{23}$ sobre esses predicados préconstruídos, ao mesmo tempo em que silencia tantos outros predicados, e os reelaboram de acordo com suas próprias categorias semânticas, traduzindo de maneira positiva os predicados que atribuem uma imagem favorável ao seu enunciador e de forma negativa aqueles que prejudicam sua imagem.

A esse respeito, é interessante acompanhar como Mosca (2007b, p. 307) elucida essa questão, vinculando as noções de ethos (imagem de si), de estereótipo e de memória discursiva:

Quando se fala de imagem de si ou de auto-representação e também quando entra a imagem do outro, há que contar com os estereótipos que circulam nas sociedades em questão e que fazem parte de seu acervo, isto é, de sua memória discursiva.

Deve-se entender também que a questão em torno da imagem prévia do enunciador não se limita a apenas um problema de reelaboração ou adequação de imagem, porque o que se coloca diante do analista é uma relação polêmica controversa entre dois discursos sobre a aceitação ou o rechaço do discurso do Outro sobre si mesmo.

Já Maingueneau (2005 [1999], p. 71), por sua vez, entende que "se o ethos está crucialmente ligado ao ato de enunciação, não se pode ignorar [...] que o público constrói representações do ethos do enunciador antes mesmo que ele fale", propondo, assim, que se faça a distinção entre ethos discursivo e ethos prédiscursivo, em que "só o primeiro corresponde à definição de Aristóteles".

\footnotetext{
${ }^{23}$ Brandão (1998, p. 128) explica que, "para a Análise do Discurso, a noção de memória discursiva nada tem a ver com a noção de memória tal como concebida pela Psicologia ou pela Psicolingüística", pois "a noção de memória discursiva diz respeito à existência histórica do enunciado no interior de práticas discursivas reguladas por aparelhos ideológicos". Gregolin (2000, p. 20) corrobora esse ponto de vista, afirmando que "não se trata de memória psíquica ou neurofisiológica, mas de memória social, memória coletiva que [...] se inscreve, como um 'conjunto de traços discursivos', em um arquivo textual".
} 
Em outro artigo, Maingueneau (2008, p. 16) retoma essa mesma reformulação, complementando-a com um exemplo que nos parece contradizer o aparato teórico que o autor constrói, uma vez que assume a ideia de um "ethos nãodiscursivo". Vejamos:

Certamente existem tipos de discurso ou de circunstâncias para as quais não se espera que o destinatário disponha de representações prévias do ethos do locutor: assim é quando lemos um texto de um autor desconhecido. Mas isso funciona de outro modo no domínio político ou na imprensa "de celebridades", por exemplo, em que a maior parte dos locutores, constantemente presentes na cena midiática, é associada a um tipo de ethos não-discursivo que cada enunciação pode confirmar ou infirmar.

O problema acima colocado por Maingueneau (2008) não diz respeito à existência do que ele chamou de "ethos não-discursivo", mas sim à problemática suscitada em torno da relação entre leitura e discurso, pois o que está sendo discutido pelo autor são os conhecimentos prévios mobilizados pelo leitor no próprio ato de leitura, o que consiste em outro problema que não o desta pesquisa. Portanto, a esse respeito, reiteramos a afirmação que fizemos acima: o que se está tentando considerar é "o discurso do Outro sobre si mesmo". Trata-se, pois, de um fenômeno próprio à interdiscursividade, e não à esfera do "não-discursivo".

Desse modo, como não se pode negar a existência de uma imagem prévia do enunciador, uma vez que a enunciação de seu discurso pertence a uma cadeia própria de discursos já enunciados, parece-nos mais coerente recobrir esse fenômeno, que é discursivo, utilizando o termo "imagem prévia do enunciador", ao invés de ethos prévio ou ethos pré-discursivo, reservando, mutatis mutandis, o termo ethos apenas para o fenômeno apresentado por Aristóteles desde a sua Retórica.

Uma vez que tratamos dos problemas do ethos, é importante que passemos a abordar as noções conexas do ethos. Assim, em primeiro lugar, devemos ter em mente que, segundo Maingueneau (1997 [1987]), o ethos é inseparável de um antiethos. Para ilustrar essa relação entre o ethos e seu anti-ethos, o analista francês oferece o seguinte exemplo:

[...] quando Saint-Just lembrava o mítico camponês do Danúbio, remetia não apenas a uma dêixis, mas ainda e sobretudo ao ethos do enunciador que, por estar extremamente próximo à natureza, expressa a verdade em toda sua brutalidade. Este ethos, na realidade, é inseparável de um "anti-ethos", aquele da aristocracia corrompida cuja linguagem não passa de artifício ( $p$. 47). 
A construção do ethos não só remete a um anti-ethos, como também se apoia na construção do anti-ethos ou dos anti-ethé. À medida que a construção discursiva de um ethos $x$ acarreta a construção de um anti-ethos não $x$, constrói-se uma correlação que é apresentada ao coenunciador para a incorporação do ethos.

A noção de incorporação é proposta por Maingueneau (2005, p. 72) para dar conta da relação entre ethos e coenunciador ou, ainda, para designar a ação do ethos sobre o coenunciador. Uma vez que o entendimento do processo de persuasão pelo ethos não se exaure na sua descrição em si, é preciso compreender que a enunciação, ao dar corpo ao fiador, possibilita que o coenunciador incorpore, assimile o modo de se comportar desse corpo enunciante, tendo a ilusão de que ele faz parte de um corpo, um grupo social e ideológico.

Assim, para Maingueneau (2005, p. 73), o processo de incorporação está concluído quando o coenunciador se vê como membro de "uma comunidade imaginária dos que aderem a um mesmo discurso". Desse modo, quando se fala em incorporação, está-se determinando o papel que a imagem do corpo do enunciador cumpre no processo persuasivo, mas não o corpo restrito a uma compleição física, e sim um corpo dotado de caráter e de reconhecimento sócio-histórico-cultural. Nesse sentido, Maingueneau (2008, p. 17) afirma que:

A perspectiva que defendo ultrapassa em muito o domínio da argumentação. Para além da persuasão por meio de argumentos, essa noção de ethos permite refletir sobre o processo mais geral de adesão dos sujeitos a um certo discurso.

Em síntese, Maingueneau (2006, p. 60) argumenta que, embora a multiplicidade do atual emprego do termo ethos torne difícil uma estabilização dessa noção, é possível manter acordo sobre três pontos, a saber:

- O ethos é uma noção discursiva, ele se constitui por meio do discurso, não é uma "imagem" do locutor exterior à fala;

- O ethos é fundamentalmente um processo interativo de influência sobre o outro;

- É uma noção fundamentalmente híbrida (sócio-discursiva), um comportamento socialmente avaliado, que não pode ser apreendido fora de uma situação de comunicação precisa, ela própria integrada a uma conjuntura sócio-histórica determinada. 
Parece-nos que, ao apontar para uma corporalidade reconhecida sóciohistoricamente, o ethos suscita, invariavelmente, uma imagem antropomórfica. Todavia, como o ethos associa-se à imagem do enunciador, é preciso indagar sobre o ethos de um discurso cuja imagem do enunciador remete a uma instituição. Tratase de abordar a construção do ethos de discursos assinados por enunciadores não antropomórficos (instituições, empresas públicas e privadas, ONGs etc.), um tipo de ethos que apresenta suas dificuldades por não abarcar a imagem humana de um indivíduo, mas a imagem humanizada de uma corporação.

Nesse caso, parece óbvio que não precisa ser "humano" para ser, por exemplo, "racional", "técnico" ou "amável"; mas será que ignorar tal distinção não traz prejuízos ao cotejar o discurso político de um parlamentar na tribuna e o discurso político assinado por uma sigla partidária em uma placa de anúncio (outdoor) desprovida de imagens? Eis a necessidade de abordar o ethos institucional.

Assim, utilizamos o termo "ethos institucional" para recobrir a ideia do ethos construído em discursos cujos enunciadores não assumem uma figura antropomórfica. Essa formulação apoia-se no que diz Aristóteles (1998 [c.400 a.C], p. 73) em sua Retórica:

O maior e mais eficaz de todos os meios para se poder persuadir e aconselhar bem é compreender as distintas formas de governo, e distinguir os seus caracteres, instituições e interesses particulares [grifo nosso].

Lembrando que o termo "caracteres" é a tradução portuguesa encontrada para a palavra grega ethé, podemos entender com acuidade a relação entre ethos e instituição sugerida nesse trecho da Retórica, em que Aristóteles trata do ethos não no sentido da imagem que o orador constrói de si em seu discurso, mas no sentido das características próprias de uma instituição. Assim, da mesma forma que o orador, em seu discurso, deve construir de si um ethos que inspire confiança em seu auditório, as instituições constroem, incessantemente, seu próprio ethos, o qual é perceptível aos seus coenunciadores como algo dado a priori.

No que diz respeito à análise do ethos institucional dos jornais $O$ Globo e Correio da Manhã, a primeira observação que deve ser feita tange ao nome do jornal, a entidade responsável pela enunciação da primeira página jornalística.

Maingueneau (2002 [1998], p. 207) diz que os nomes de marcas e de produtos povoam nosso mundo com entidades que não são nem seres humanos, 
nem animais, nem objetos e possuem a particularidade de ser apresentados como os responsáveis pelos seus enunciados. Segundo o analista, o nome da marca é um tipo de nome próprio que só pode designar uma única entidade. Se existem inúmeros seres com o nome de José, não temos dois jornais com o nome de Folha de São Paulo, por exemplo. Ademais:

[...] a marca se desliga do estatuto de fabricante de produtos para se tornar um princípio muito abstrato, produtor de discursos que lhe permitem investir em seus produtos um certo número de valores específicos: a seriedade, a juventude etc. (op.cit., p. 208).

E esse produtor de discursos materializa-se discursivamente na figura do enunciador, como bem sintetiza Hernandes (2001, p. 45):

Todo meio de comunicação de massa tem uma marca, cuja identidade é mostrada visualmente por um $\log _{0}{ }^{24}$ e verbalmente por um slogan. São a representação de um "eu" que assume o discurso, um "autor" construído pelo texto ou, em outras palavras, um simulacro do sujeito da enunciação.

E, como estamos tocando na questão do enunciador, o nome da marca (do jornal, no caso desta pesquisa), o logo e o slogan, assim como o patrimônio ético construído cotidianamente pela empresa jornalística, constroem a imagem dessa marca, o que nos leva à questão do ethos discursivo. E essa nossa colocação encontra guarida no que Maingueneau (2002 [1998], p. 212) afirma sobre a imagem da marca:

\begin{abstract}
O nome de uma marca, como qualquer nome próprio, está associado a um conjunto variável de representações sedimentadas ao longo do tempo, uma "imagem da marca", sobre a qual a empresa deve agir constantemente. A evolução dessa imagem se deve em boa parte aos discursos que a empresa emite e emitiu sobre ela mesma e sobre seus produtos, em particular pela publicidade.
\end{abstract}

Para Maingueneau (p. 215), o que importa saber do nome de uma marca são os seus efeitos de sentido dentro do processo de comunicação. E, mais especificamente, Mouillaud (2002, p. 86) explica que "a apresentação de seu nome [o do jornal] se opera na presença de outros nomes, aqueles dos jornais que fazem parte do mesmo paradigma", estabelecendo-se "entre os jornais [...] uma relação polêmica antes mesmo das polêmicas que os opõem". Nesse sentido, é importante

\footnotetext{
${ }^{24}$ Segundo Hernandes (2001, p. 45), "existem dois tipos de logos: a logomarca - uma representação mais visual e abstrata, caso da árvore estilizada do Bradesco - e o logotipo - marca constituída de um grupo de letras, caso da VEJA".
} 
sublinhar que a polêmica entre os posicionamentos d'O Globo e do Correio da Manhã se faz presente mesmo antes de a edição do dia chegar às bancas de jornal.

A marca da empresa jornalística ou o nome do jornal constrói não só um patrimônio ético em torno de sua imagem, como também todo um imaginário capaz de captar a adesão do leitor mesmo antes de ele abrir o jornal do dia. Podemos dizer, desse modo, que o ethos institucional de uma organização empresarial desempenha seu papel na construção da hegemonização de um discurso, exercendo influência sobre a sociedade, inclusive sobre o seu modo de ver o mundo, de ser e de se comportar no mundo, de sentir no mundo, ou seja, sobre o seu ethos e o seu pathos. Isso por que, ao aderir ao seu discurso, o coenunciador (leitor) incorpora o ethos do enunciador (jornal). A esse respeito, Mouillaud (2002, p. 86) diz, ainda, que:

O nome-de-jornal não é mais objeto da leitura, torna-se seu envelope. Ele
se retira acima de todos os outros enunciados. A partir desta posição
destacada, assegura a coerência e a continuidade dos enunciados à
maneira de uma pressuposição. Constitui o princípio de uma espera, por
parte do leitor, de certos enunciados. Firma um pacto com o leitor que, por
ser implícito, não é, do mesmo, menos significativo.

Tendo em vista que o ethos discursivo é, basicamente, um modo de enunciar que sustenta a corporalidade do enunciador, conferindo-lhe o estatuto de fiador de seu próprio discurso, é importante destacar, neste momento, que a depreensão do ethos pode ser feita em conjunto com outras noções linguísticas e discursivas relacionadas a diversos fenômenos enunciativos. Em nossa pesquisa de mestrado, procedemos a um breve levantamento de alguns fatores linguístico-discursivos para a depreensão do ethos, tais como a projeção da enunciação no enunciado e a heterogeneidade enunciativa. Esbocemos, pois, uma síntese dessas categorias de análise empregadas na pesquisa anterior.

Partindo do pressuposto de que a enunciação somente pode ser analisada por meio de sua projeção no enunciado, ou seja, observando-se as marcas implícitas ou explícitas da enunciação no enunciado, mostramos que é possível apurar traços do ethos com base no emprego das formas dêiticas e das marcas das modalidades. Considerando os dêiticos como "as palavras que designam, dentro do enunciado, os elementos constitutivos de toda enunciação, que são o locutor, o alocutário, o lugar e o tempo da enunciação" (CERVONI, 1989, p. 23), mostramos que sua análise permite verificar os efeitos de sentido atrelados à própria 
subjetividade enunciativa e, consequentemente, ao ethos. Já a análise das marcas da modalidade, por sua vez, permite evidenciar a atitude do enunciador perante seu enunciado e seu coenunciador, uma vez que:

[...] as modalidades são facetas de um processo mais geral de modalização, de atribuição de modalidades ao enunciado, pelo qual o enunciador, em sua própria fala, exprime uma atitude em relação ao destinatário e ao conteúdo de seu enunciado (CHARAUDEAU; MAINGUENEAU, 2004, p. 334).

$\mathrm{Na}$ referida pesquisa, mostramos, também, que a análise das formas da heterogeneidade enunciativa permite a depreensão do ethos discursivo, pois os modos de negociação de uma identidade discursiva com a sua alteridade imprimem um modo de enunciar e, portanto, revelam o modo de ser de uma subjetividade discursiva, o que deságua no ethos.

Já, neste trabalho, examinaremos o ethos recorrendo, de maneira transversal, a uma ou a outra dessas categorias de análise, pois o foco da presente pesquisa incide sobre o papel do pathos na construção do ethos, ou seja, pretendemos depreender a qualidade dos ethé produzidos pelos discursos d'O Globo e do Correio da Manhã com base nos pathé que emergem desses discursos. Assim, passemos ao estudo da noção de pathos discursivo. 


\subsubsection{O pathos discursivo}

Mosca (2004) mostra como, ao longo dos séculos, os termos associados ao pathos, tais como sentimento, emoção, estado de ânimo, humores e paixões foram sendo empregados como sinônimos e como uma variedade de fenômenos foi, muitas vezes, recoberta por apenas um desses termos.

A autora alerta também para o fato de que "não há consenso nem mesmo entre os psicólogos que tratam do assunto" e que estamos diante de um problema que remonta à Antiguidade:

Desde os filósofos gregos escreveu-se e pensou-se a respeito desses conceitos. Para os filósofos medievais, passio, affectus e affectio passaram a ser usados como sinônimos, alguns filósofos revelando preferência por um ou outro termo. Assim, Santo Agostinho atribuía as denominações de affectus e affectio à categoria mais ampla de movimentos da alma e a de passio à subcategoria de movimento da alma contrários à natureza (MOSCA, 2004, p. 130).

Se, numa visada histórica, Mosca compreende a flutuação dos termos como questão de preferência de cada filósofo por um ou outro termo, Plantin (2003, p. 111) detecta que, na atualidade, cada termo pertence a uma determinada área de conhecimento, em que o termo:

[...] sentimento está inseparável das teorias filosóficas sensualistas do conhecimento; a predominância do componente psíquico do termo emoção é, em francês, uma evolução recente, sendo o componente comportamental ("movimento") historicamente fundamental. Os humores estão enraizados na teoria médica das paixões; quanto à paixão, ela remete não somente às abordagens filosóficas da vida psíquica, mas também às teorias e às práticas dos alienistas (a palavra mudou de sentido com Esquirol, conforme Gauchet \& Swain 1983); e para deixar mais complexo ainda o quadro, ela é utilizada em francês para traduzir o latim affectus dos tratados de retórica; ora esse termo corresponde a movimentos de emoções típicas, como a cólera $^{25}$.

Parece-nos que a organização desse emaranhado de termos e fenômenos a eles correspondentes não se afigura como tarefa das Ciências da Linguagem, uma vez que a pesquisa abrangeria a retórica greco-latina, estudiosos medievais como

25 Tradução nossa. No original: [...] sentiment est inséparable des théories philosophiques sensualistes de la connaissance ; la dominance de la composante psychique du terme émotion est, en français, une évolution récente, la composante comportementale (“mouvement") étant historiquement fondamentale. Les humeurs sont enracinées dans la théorie médicale des passions ; quant à passion, il renvoie non seulement aux approches philosophiques de la vie psychique, mais aussi aux théories et aux pratiques des aliénistes (le mot a changé de sens avec Esquirol, d'après Gauchet; Swain 1983); et pour complexifier encore le tableau, il est utilisé en français pour traduire le latin affectus des traités de rhétorique; or ce terme correspond à des mouvements d'émotions typiques, comme la colère (PLANTIN, 2003, p. 111). 
Santo Agostinho - que legitimou o pensamento aristotélico no interior da Igreja Católica - e, finalmente, as modernas contribuições da Psicologia, da Psicanálise e de outras disciplinas das Ciências Humanas.

Situando seu trabalho numa perspectiva de análise da linguagem, mais especificamente na esteira dos estudos sobre a argumentação, Plantin (2003, p. 118) apresenta um projeto de pesquisa que tem por objetivo:

[...] estabelecer os princípios que permitem definir a orientação emotiva de um discurso, quer seja essa emoção apresentada ou não por tal ou tal ator. Em outras palavras, um discurso pode veicular uma emoção mesmo se os atores desse discurso não explicitam emoção alguma, mas se eles apresentam ou atribuem uma ou mais emoções ao discurso, então a análise deve levá-la em conta. Em outros termos, pesquisamos os princípios de organização dos traços de emoção ou marcadores de orientação emocional, (que poderíamos chamar de "patemas") em um discurso ${ }^{26}$.

Segundo Plantin (2003, 2010 [1998]), esses traços de emoção no discurso, os patemas, podem ser examinados com base no que ele chama de enunciados de emoção, noção tomada de empréstimo à léxico-gramática de Maurice Gross. Basicamente, um enunciado de emoção é uma estrutura sintática, da qual podemos determinar lugares psicológicos e os sentimentos atribuídos a esses lugares. Os lugares psicológicos são os atores envolvidos no enunciado de emoção, isto é, "a quem são eventualmente atribuídas as experiências” (PLANTIN, 2010 [1998], p. 61).

Para ilustrar essa formulação, reproduziremos aqui o exemplo oferecido pelo autor:

Em "Luiz irrita Léia", temos acesso a dois lugares psicológicos potenciais, Luiz e Léia, mas é a um único destes dois lugares que é atribuído um sentimento, a irritação (op. cit., p. 62).

Plantin (2010 [1998]) discute, ainda, sobre a determinação das emoções em enunciados que não a expressam diretamente por meio de um nome ou de um verbo. A um enunciado do tipo "Como suportarei o olhar de meus filhos? Nunca mais terei coragem de me olhar no espelho" (p. 63) pode ser atribuído o sentimento de

\footnotetext{
${ }^{26}$ Tradução nossa. No original : «L'objectif de la recherche présentée ici est d'établir les principes permettant de définir l'orientation émotive d'un discours, que cette émotion soit affichée ou non par tel ou tel acteur. Autrement dit, un discours peut véhiculer une émotion même si les acteurs de ce discours n'en explicitent aucune ; mais s'ils affichent ou en attribuent une ou plusieurs, alors l'analyse doit la prendre en compte. Autrement dit, nous recherchons les principes d'organisation des traits d'émotion, ou marqueurs d'orientation émotionnelle, (que l'on pourrait appeler "pathèmes") dans un discours » (PLANTIN, 2003, p. 118).
} 
/vergonha/ ${ }^{27}$, pois "o discurso cultural liga alguns lugares comuns a algumas emoções" (p. 63). Em síntese, Plantin desenvolve uma pesquisa que o permite abranger "um primeiro percurso textual e uma primeira marcação das emoções ditas, diretamente ou indiretamente" (p. 64).

Plantin (2003, p. 118; 2010 [1998], p. 65) apresenta, ainda, outra pesquisa conduzida por ele, na qual "se apoia em regras desenvolvidas pela retórica antiga e clássica e em proposições feitas pela Análise do Discurso, pela Pragmática e pela Psicologia"28.

Assim, o pesquisador recorre às técnicas da emoção da retórica antiga, reportando-se ao Manual de Retórica Literária, de Lausberg ${ }^{29}$, especificamente no que tange às figuras de emoção. Plantin (2010 [1998]) destaca que o estudioso alemão "estabelece uma conexão entre figuras do afeto e as figuras em várias palavras e, também, uma conexão com o ornamento" (p. 65), ressalvando, porém, que irá considerar "estas figuras não mais como ornamentos, mas como instrumentos destinados a suscitar a emoção no interlocutor, os princípios geradores da emoção" (p. 65). Nesse estudo, Plantin (2010 [1998]) apoia-se no que Lausberg chama de três maneiras de suscitar a emoção e as apresenta como regras ou preceitos, da seguinte maneira:

(i) Regra sobre a emoção encenada: (R1), "Mostre-se emocionado!". [...] O orador deve se colocar no estado emocional que ele deseja transmitir ( $p$. $65)$.

(ii) Regras sobre a apresentação e a representação:

- (R2) "Mostre objetos emocionantes": o punhal do assassino, a chaga do ferido [...]

- (R3) "Mostre imagens!": imagens de objetos ou cenas emocionantes $[\ldots]$

- (R4) [...] "Mostre a emoção!": [...] mostre [...] a alegria dos vencedores, a decepção dos vencidos... (p. 66).

(iii) Regras sobre a mimese: (R5) "Descreva coisas emocionantes!". [...] Se você não pode mostrar nem o objeto, nem o filme, então descreva estes objetos e estes eventos emocionantes [...] (p. 66).

\footnotetext{
${ }^{27}$ Plantin (2010 [1998]) emprega as barras para indicar uma emoção reconstruída, diferentemente de uma emoção dita explicitamente no enunciado.

${ }^{28}$ Tradução nossa. No original : "Cette recherche s'appuie sur des règles dégagées par la rhétorique ancienne et classique, ainsi que sur des propositions faites en analyse du discours, en pragmatique et en psychologie » (PLANTIN, 2003, p. 118).

${ }^{29}$ LAUSBERG, H. Handbuch der literarischen Rhetorik. Munich: Max Hueber, 1960.
} 
A pesquisa de Plantin (2010 [1998], p. 67) recorre, ainda, aos trabalhos de Ungerer $^{30}$ cuja teoria entende que "as emoções do leitor são desencadeadas em conformidade com três Princípios da inferência emocional", de modo a explorar os indutores de emoção no texto jornalístico. Tratou de observar como os desencadeadores linguísticos inferem emoção: o uso de dêiticos e de termos de uso familiar, para inferir a proximidade entre o leitor e o fato noticiado; o uso de vocabulário de "calamidades", para inferir o risco de morte; uso de numerais, para inferir a quantidade de pessoas em risco; uso de advérbios e itens lexicais com conotações positivas ou negativas, para avaliações; etc.

A fim de dar conta das dimensões linguística e psicológica das emoções, Plantin (2010 [1998]) constrói seu arcabouço teórico, baseando-se, também, em teorias pragmáticas preocupadas em aproximar a Linguística e a Psicologia:

[...] vemos a pragmática como um lugar no qual [linguística e psicologia] poderiam finalmente e de maneira produtiva se encontrar, em parte, através da mediação da retórica (Caffi; Janney ${ }^{31}$, 1994 apud PLANTIN, 2010 [1998], p. 67).

Plantin (2010 [1998]) abrange, ainda, a dimensão cognitiva das emoções, fundamentando-se nos estudos psicológicos empreendidos por Scherer, segundo o qual "toda emoção [...] é analisável através de vários componentes (ou sistemas)" (Scherer $^{32}, 1993$ apud PLANTIN, 2010 [1998], p. 69). Dentre alguns componentes, Plantin destaca que "o componente de avaliação cognitiva parece particularmente interessante para a análise do discurso" (p. 69), uma vez que a pesquisa de Plantin "consiste em trabalhar com operações linguísticas que correspondem a estas operações cognitivas” (p. 71).

Ao final dessa sua exposição, Plantin (2010 [1998], p. 71-77) mostra que sua pesquisa desenvolve o que o autor chama de tópica da emoção, noção inspirada na retórica antiga, para abordar enunciados que suscitam emoção, mas que não contém termo de emoção nem expressão que permita recuperá-lo (PLANTIN, 1999). Assim, para o autor:

${ }^{30}$ UNGERER, F. Emotions and emotion language in English and German news stories. In: NIEMEYER, S.; DIRVEN (eds). The language of emotions. Duisburg: Gerhard Mercator University, 1995. p. 297-328.

31 CAFFI, CL.; JANNEY, R.W. Toward a pragmatics of emotive communication. Journal of pragmatics, n. 22, p. 325-373, 1994.

${ }^{32}$ SCHERER, K.R. Les emotions: Fonctions et composantes. Cahiers de psychologie cognitive, n. 4, p. 9-39, 1984. 
A representação do evento estímulo é uma construção argumentativa, retórica, regulada por uma tópica. Sabe-se que uma tópica é um conjunto de regras que governam a produção de argumentos (PLANTIN, 2010 [1998], p. 71).

O que é importante ressaltar é que Plantin - apoiando-se em teorias de áreas diversas - destaca, ao final, a dimensão discursiva de seu objeto de estudo. Desse modo, ao considerar que uma tópica é um conjunto de regras, Plantin (2010 [1998], p. 73) constrói uma tópica das emoções e a apresenta, conforme o Quadro 1, apropriando-se dos aportes teóricos da retórica clássica, "dos princípios de inferência emocional propostos por Ungerer, das categorias linguísticas de construção da emoção de Caffi e Janney, [...] e do sistema de facetas teorizado por Scherer" (PLANTIN, 2010 [1998], p. 73). Vejamos:

Quadro 1 - Tópica das emoções, segundo esquema de Plantin (2010 [1998])

\begin{tabular}{|c|c|}
\hline T1: O quê? & $\begin{array}{l}\text { Casamento / enterro; façanha / derrota; má ação / boa ação; amigo / } \\
\text { inimigo }\end{array}$ \\
\hline T2: Quem? & mulheres, crianças, o Presidente, um mendigo, os notáveis \\
\hline T3: Como? & Diria que era um campo de batalha. \\
\hline T4: Quando? & $\begin{array}{l}\text { No dia de seus } 20 \text { anos. } \\
\text { Morto na guerra em } 10 \text { de novembro de } 1918 .\end{array}$ \\
\hline T5: Onde? & $\begin{array}{c}\text { O caminhão explode em um camping. } \\
\text { Assassinato na catedral. }\end{array}$ \\
\hline T6: Quanto? & $\begin{array}{l}\text { A maior catástrofe do transporte aéreo de todos os tempos. Uma } \\
\text { explosão incrível. }\end{array}$ \\
\hline T7: Por quê? & $\begin{array}{l}\text { O acidente foi provocado por um deslizamento de terra / por um } \\
\text { roda-dura bêbado. }\end{array}$ \\
\hline T8: Consequências? & $\begin{array}{l}\text { A gente fala que nosso franco é forte, mas serão necessários sete } \\
\text { francos para ter um único Euro! }\end{array}$ \\
\hline T9: Normas? & A pátria está em perigo. \\
\hline T10: Controle? & Inexoravelmente. \\
\hline T11: Distância de y? & $\begin{array}{c}\text { Estrangeiros. } \\
\text { Pessoas como você e eu. }\end{array}$ \\
\hline T12? Aprovação? & Genial! \\
\hline
\end{tabular}

Fonte: Plantin (2010 [1998], p. 73).

Diante do exposto, podemos concluir que Plantin (2010 [1998], p. 77) apresenta, de fato, não duas pesquisas distintas, mas complementares, constituindo, assim, um programa de pesquisa preocupado em mostrar que o estudo da argumentação está longe de ser uma disciplina alexitímica, que coloca "como ideal uma linguagem objeto da qual é banida toda expressão de sentimentos". Nas 
palavras do autor, sua pesquisa pôde revelar "o contraste entre a profundidade emocional de numerosos discursos argumentativos [...] e a falta de instrumentos teóricos que permitam explicar esta dimensão nas abordagens lógicas padrão da argumentação".

Embora a obra de Plantin contribua proficuamente para a análise da argumentação, oferecendo conceitos e métodos para a depreensão das emoções manifestadas, explícita e implicitamente, no enunciado, é preciso recorrer a outras teorizações e proceder a algumas formulações sobre as paixões no discurso, para que esse fenômeno possa ser abordado não só em sua dimensão argumentativa, mas também em sua dimensão ideológica e sócio-histórica.

Dessa maneira, é necessário situar o trabalho que vem sendo desenvolvido por Patrick Charaudeau (2010 [2000], 2007b), o qual propõe uma abordagem das emoções voltada unicamente à sua dimensão discursiva, ou, como prefere o autor, "linguajeira".

É importante dizer que, embora Charaudeau trabalhe com uma vertente de análise de discurso - a análise semiolinguística do discurso - fundamentada em postulados teóricos distintos daqueles assumidos nesta pesquisa, recorreremos a algumas formulações que o linguista francês elaborou acerca das paixões no discurso.

Charaudeau (2010 [2000]) entende que, para a análise das emoções no discurso, é preciso situar a Semiolinguística em relação à Psicologia e à Sociologia, argumentando que 0 analista do discurso deve afastar-se das perspectivas psicológica e sociológica, ao mesmo tempo em que a Análise do Discurso precisa delas. Para Charaudeau, o afastamento se deve ao fato de que tais visadas recaem sobre o indivíduo e seu comportamento, e sobre o comportamento humano no jogo de regras e normas sociais, enquanto que, na perspectiva desse autor, "a análise do discurso tem por objeto de estudo a linguagem, enquanto produtora de sentido em uma relação de troca, visto que ela traz em si mesma o signo de uma coisa que não está nela, mas da qual ela é portadora" (p. 25). Porém, para o semiolinguista, "a análise do discurso precisa delas [das perspectivas psicológica e sociológica], na medida em que suas análises evidenciam os mecanismos de intencionalidade do sujeito, os da interação social e a maneira como as representações sociais se constituem" (p. 26). Assim, Charaudeau (2010 [2000], p. 25) parte do ponto de que uma emoção é: 
[...] sinal daquilo que pode acontecer ao sujeito a respeito do fato de que ele mesmo estaria em condições de reconhecê-lo como uma "figura", como um discurso socialmente codificado que [...] Ihe permitiria dizer "É realmente isso, o medo!" ou simplesmente "Tenho medo!".

Nesse contexto teórico, também é importante ressaltar que Charaudeau (2010 [2000]) filia-se a uma perspectiva retórica das emoções, concebendo as emoções como "efeitos patêmicos do discurso" (p. 26). Segundo o autor, as emoções instauram-se por meio de "categorias de discursos que pertencem a diferentes ordens (inventio, dispositio, elocutio, actio), nas quais haveria [...] uma 'tópica' da emoção - uma 'patemia' [...], que seria constituída por um conjunto de 'figuras'” (p. 25-26). Desse modo, o autor fundamenta como a análise do discurso interessa-se pela emoção não "como realidade manifesta, vivenciada por um sujeito", mas como "um efeito visado (ou suposto), sem nunca ter a garantia sobre o efeito produzido" (p. 34). E, para nossa pesquisa, uma das principais contribuições de Charaudeau é filiar os estudos discursivos das emoções aos retóricos, pois:

É a razão pela qual prefiro os termos "pathos", "patêmico" e "patemização" em lugar de emoção. Isso me permite, por um lado, inserir a análise do discurso das emoções na filiação da retórica que desde Aristóteles trata os discursos em uma perspectiva de visada e de efeitos [...], por outro lado, me permite dissociar a análise do discurso, [...], da psicologia e da sociologia (op. cit., p. 35).

Uma vez que apresentamos as principais teorias sobre as emoções no discurso, com as quais iremos dialogar, passaremos, neste momento, a tratar da concepção da noção de pathos discursivo adotada nesta pesquisa. Em primeiro lugar, é preciso dizer que nosso intento, neste trabalho, é associar o pathos discursivo ao ethos discursivo tal como formulado por Maingueneau em seu quadro de Análise do Discurso, que é o mesmo assumido por nós.

Feitas essas considerações, comecemos nossa exposição, voltando-nos à Retórica de Aristóteles, pois é nela que se define a segunda prova artística de persuasão fornecida pelo discurso, a saber: o pathos, ou as paixões ${ }^{33}$ :

Persuade-se pela disposição dos ouvintes, quando estes são levados a sentir emoção por meio do discurso, pois os juízos que emitimos variam conforme sentimos tristeza ou alegria, amor ou ódio (ARISTÓTELES, 1998 [c.400 a.C], p. 49).

\footnotetext{
${ }^{33}$ Plebe $(1978$, p. 42$)$ adverte que a tradução de pathos por "paixão" deve ser entendida de forma aproximada, já que pathos "não é 'paixão' no puro sentido de uma inflamada emoção, mas é o mundo todo da irracionalidade emocional".
} 
As paixões são todos aqueles sentimentos que, causando mudança nas pessoas, fazem variar seus julgamentos (ARISTÓTELES, 2000 [c.400 a.C], p. 5).

Ao delinear as perspectivas contemporâneas dos estudos retóricos, Declercq (1992) sublinha que a partir do momento em que "se trata de estudar os atos de fala e as relações de interlocução que ligam o emissor e o destinatário de um discurso, a convergência entre a pragmática e a retórica se estabelece de facto"34 (p. 142-143). Assim, é nesse contexto que Declercq compreende que "as problemáticas da enunciação e da interlocução recobrem o campo retórico das relações entre o orador e seu auditório" (p. 143-144), o que nos permite trabalhar com uma abordagem enunciativa do ethos e do pathos retóricos.

Com base nesses pressupostos, podemos retomar os dois excertos supracitados de Aristóteles e dizer que, do ponto de vista enunciativo, eles deixam patente que o pathos é produzido por meio da enunciação de seu próprio discurso e pressupõe a interação entre os sujeitos desse ato enunciativo. Logo, o exame dos mecanismos de construção das paixões no discurso deve focalizar a instância subjetiva da enunciação, que se desdobra em duas faces: enunciador e coenunciador.

Desse modo, reiteramos a ideia de que a tarefa do analista não se volta ao exame das paixões efetivamente experimentadas pelos indivíduos empíricos ditos de "carne e osso" nem à descrição de estados fisiológicos de invejosos, indignados ou coléricos, por exemplo, mas sim à compreensão das paixões construídas no discurso. Retomemos, pois, o que Charaudeau (2010 [2000], p. 34) diz a esse respeito:

A análise do discurso não pode se interessar pela emoção como realidade
manifestada, vivenciada por um sujeito. Ela não possui os meios
metodológicos. Em contrapartida, ela pode tentar estudar o processo
discursivo pelo qual a emoção pode ser estabelecida, ou seja, tratá-la como
um efeito visado (ou suposto), sem nunca ter a garantia sobre o efeito
produzido.

Bem entendido que estamos tratando de efeitos de sentido produzidos no e pelo discurso, é preciso ter em mente que, com base no primado do interdiscurso (cf. Maingueneau, 1997 [1987]), as paixões são construídas na interdiscursividade, pois

${ }^{34}$ Tradução nossa. No original: « [...] il s'agit d'étudier les actes de la parole e les rapports d'interlocution lian l'émetteur et le destinataire d'un discours, la convergence de la pragmatique e de la rhétorique s'établit de facto » (DECLERCQ, 1992, p. 142-143). 
os sentidos do discurso - entre eles os efeitos de sentido relacionados às paixões submetem-se a um processo de tradução, em que uma formação discursiva, ao integrar o seu Outro, sob a forma, por exemplo, "de uma citação, ela está apenas 'traduzindo' o enunciado deste Outro, interpretando-o através de suas próprias categorias" (p. 120). O autor explica que, nesse processo de tradução, estabelece-se uma relação polêmica entre as formações discursivas, em que "uma formação discursiva opõe dois conjuntos de categorias semânticas, as reivindicadas ([chamadas] de "positivas") e as recusadas (as "negativas")" (p. 122).

Nessa relação polêmica, as paixões discursivas, que remetem a modos de sentir, estão atreladas a certos posicionamentos discursivos e os diferem no interior de uma polêmica. Voltando nosso olhar para a dimensão argumentativa do discurso, Plantin (2008, p. 124) explica que "é impossível construir um ponto de vista, um interesse, sem a eles associar um afeto, dado que as regras de construção e de justificação dos afetos não são diferentes das regras de construção e de justificativa dos pontos de vista". Em matéria de discurso jornalístico, é importante notar que as paixões têm papel crucial no processo de adesão do público-leitor ao ponto de vista proposto pelo jornal, bem como na construção da legitimidade de seu próprio discurso.

É nesse sentido que podemos dizer que as paixões estão associadas a uma determinada doxa, ou seja, aos valores e às crenças de uma determinada comunidade argumentativa, tal como concebe Mosca (2007b, p. 302):

\footnotetext{
A idéia de comunidade argumentativa, formada em torno de princípios comuns (crenças, propostas, aspirações), postulada por Chaïm Perelman, é um elo que reforça a identidade, porque movida por aquilo que há de comum entre os seus membros, compreendendo aqui a afetividade e os valores que a integram.
}

Já, num quadro teórico de Análise do Discurso, a ideia de comunidade argumentativa equivaleria ao que Maingueneau (2000, p. 29-30) chama de "comunidade discursiva", ou seja, "grupos sociais que produzem e administram um certo tipo de discurso", os quais podem ser compreendidos tanto por "enunciadores de um mesmo tipo de discurso (jornalístico, científico...)", quanto por "enunciadores que dependem de posicionamentos concorrentes (um jornal, um partido político, uma escola científica...)". 
Essa relação entre o pathos e a doxa é, igualmente, atestada tanto por Amossy (2006), quanto por Charaudeau (2007b). Vejamos:

\begin{abstract}
A Análise do Discurso leva em conta o elemento emocional tal como ele se inscreve no discurso em estreita ligação com a doxa do auditório e os processos racionais que visam a arrebatar a adesão (AMOSSY, 2006, p. $186)^{35}$.
\end{abstract}

A emoção pode ser percebida na representação de um objeto em direção ao qual o sujeito se dirige ou busca combater. E como estes conhecimentos são relativos ao sujeito, às informações que ele recebeu, às experiências que ele teve e aos valores que lhe são atribuídos, pode-se dizer que as emoções, ou os sentimentos, estão ligados às crenças (CHARAUDEAU, 2007b, p. 241).

Todavia, é interessante observar que Amossy (2006, p. 100), ao definir a noção de doxa como "o espaço do plausível tal como o apreende o senso comum", deixa entrever a natureza pouco pacífica dessa plausibilidade, no sentido de que a doxa pode ser um fator de construção tanto do consenso numa dada comunidade argumentativa (ou discursiva) e, ao mesmo tempo, um fator de hegemonização de um discurso, o que pode se afigurar como um elemento de entrave para a produção de discursos de ruptura ou de resistência. Acompanhemos a reflexão de Amossy (2006) sobre essa natureza paradoxal da doxa:

É interessante constatar que o que parece aceitável em Aristóteles é ora fundado sobre a opinião de todos ou da maioria, ora sobre a opinião dos entes competentes e autorizados que podem falar em nome de todos: é a autoridade que funda e legitima a endoxon (p. 100) ${ }^{36}$.

Nesse caso, é preciso compreender que as regulações do discurso incidem não apenas sobre o que é dito (e o não dito), mas também sobre o modo de dizê-lo e de senti-lo. Em outros termos, os pontos de vista, as opiniões, as crenças, os tons de dizer e as paixões a enunciar são valorizados, axiologicamente, dentro das grades culturais e impostos pelas formações discursivas. Sob o prisma da análise semiótica do discurso, Fiorin (1992, p. 63) traz uma interessante reflexão sobre essa

\footnotetext{
${ }^{35}$ Tradução nossa. No original: « [...] l'analyse du discours tient compte le élément émotionnel tel qu'il s'inscrit dans le discours en étroite liaison avec la doxa de l'auditoire et les processus rationaux qui visent à emporter l'adhésion » (AMOSSY, 2006, p. 186).

${ }^{36}$ Tradução nossa. No original: " II est intéressant de constater que ce qui paraît acceptable chez Aristote est tantôt fondé sur l'opinion de tous ou de la majorité, tantôt sur celle des êtres compétents et autorisés qui peuvent parler «a la place de tous : c'est alors l'autorité qui fonde et légitime l'endoxon »(AMOSSY, 2006, p. 100).
} 
questão da doxa enquanto grade cultural e elemento de coerção discursiva imposta à produção das paixões no discurso, ao explicar que:

[...] os simulacros construídos no e pelo discurso deixam entrever determinações modais e papéis temáticos e actanciais valorizados ou não por uma dada cultura, o que ela permite desejar, o que obriga a temer, aquilo de que faz envergonhar-se. [...]. Em suma, que desejos é preciso desejar, que desejos não se pode ter.

Outra característica do pathos discursivo que devemos destacar toca à sua (não) lexicalização no enunciado. Segundo Charaudeau (2010 [2000]) e Amossy (2006), não é necessário que uma paixão seja lexicalizada para que ela se manifeste discursivamente:

[...] o efeito patêmico pode ser obtido tanto por um discurso explícito e direto, na medida em que as próprias palavras têm uma tonalidade patêmica, quanto implícito e indireto, na medida em que as palavras parecem neutras deste ponto de vista (CHARAUDEAU, 2010 [2000], p. 37).

Na perspectiva de uma Análise do Discurso, é possível presumir dois casos de figuras principais: aquela em que a emoção é mencionada explicitamente, e aquela em que a emoção é provocada sem ser designada pelos termos de sentimento (AMOSSY, 2006, p. 187) ${ }^{37}$.

Mais do que isso, é também importante compreender que as paixões do discurso não podem ser depreendidas apenas com base naquilo que é dito. Por exemplo, o enunciado "estou confiante" pode ser dito em uma situação de ironia, em que o sujeito está querendo dizer "não estou confiante"; igualmente, o enunciado "estou com medo" pode ser usado para provocar um terceiro a uma discussão, despertando-Ihe a raiva. Sobre isso, Herman Parret (1997, p. 112) explica que "dar nome às próprias emoções, numa situação comunicativa, é às vezes uma sutil estratégia de engano e de manipulação".

Sintetizando, podemos entender que o pathos discursivo está vinculado a um conjunto de crenças compartilhadas e axiologizadas sócio-historicamente, ou seja, a um sistema de valores que determina o valor de cada paixão, conforme a circunstância em que ela é manifestada em uma dada sociedade e seu momento histórico. Projetam-se, assim, no discurso as imagens do sujeito - a de si e a do

${ }^{37}$ Tradução nossa. No original: «Dans la perspective d'une analyse du discours, on peut supposer deux cas de figures principaux : celui où l'émotion est mentionnée explicitement, et celui où elle est provoquée sans être désignée par des termes de sentiment »(AMOSSY, 2006, p. 187). 
outro - apoiadas nas paixões determinadas por um dado contexto sócio-histórico como possíveis ou não possíveis de manifestar.

Por exemplo, em uma democracia republicana de qualquer país do mundo, o discurso de um deputado acusado de corrupção deve manifestar veemente indignação; isso quer dizer que os sistemas de valores (da democracia republicana) impõem ao sujeito enunciador (deputado acusado) que ele, no mínimo, manifeste e desperte em seu coenunciador (Parlamento, opinião pública etc.) uma determinada emoção (indignação) em resposta à injustiça que ele supostamente tenha sofrido.

Enfim, parece-nos que estas são as questões essenciais que cercam a natureza do pathos discursivo e que podem orientar sua depreensão num quadro teórico de Análise do Discurso, tal como formulado por Maingueneau.

Devido às características enunciativas do discurso jornalístico, a investigação desta pesquisa recai sobre as paixões implicitamente enunciadas, e não sobre as paixões explicitamente enunciadas, uma vez que muito dos efeitos passionais desses discursos seriam negligenciados pela análise. Assim, tendo por objetivo inserir o pathos discursivo ao lado do ethos discursivo, tal como desenvolvido por Maingueneau, apresentaremos a noção de cenário passional, uma categoria de análise que formulamos para depreender o pathos discursivo.

Desse modo, compreendemos a noção de cenário passional:

a) Como uma cena de enunciação que integra a cenografia, uma das três cenas enunciativas apresentadas por Maingueneau (1997 [1987]): a cena englobante, a cena genérica e a cenografia;

b) Como uma tópica das paixões (cf Aristóteles, 2000 [c.400 a.C]; Plantin, 2010; Charaudeau, 2010), a qual, segundo Eggs (2005, p. 43), "permite inferências dedutivas a partir das situações-tipo ou dos cenários que desencadeiam determinados afetos".

Pormenorizemos esses dois aspectos. Maingueneau (1997), ao tratar do ethos e da cenografia, apresenta a relação entre uma cena enunciativa e uma noção retórica adaptada para o quadro teórico da Análise do Discurso. Assim, nossa proposta de relacionar as cenas enunciativas ao cenário passional e ao pathos discursivo significa ampliar esse quadro teórico originalmente formulado pelo pesquisador francês.

Maingueneau (2002 [1998]) apresenta as três cenas enunciativas, estabelecendo a cenografia como a cena com que o coenunciador toma contato 
mais explicitamente, uma vez que as cenas englobante e genérica (o quadro cênico) são deslocadas para o segundo plano. A cenografia consiste na cena de enunciação mais propícia aos investimentos de criação do discurso, configurando-se na dimensão criativa do discurso, na qual se engendra o simulacro de um momento, de um espaço e dos papéis sociais conhecidos e compartilhados culturalmente.

Para ilustrar, consideremos que, embora a cena englobante gerada pelo discurso jornalístico e a cena genérica instaurada pelo editorial, por exemplo, instituam os lugares sociais pré-estabelecidos do jornalista e de seu leitor, sob a forma e as coerções próprias do gênero editorial, é a cenografia que servirá como cena de captação do imaginário desse leitor, em um processo que atribuiria a esse leitor um outro lugar social.

Diferentemente das cenas englobante e genérica, que são mais suscetíveis às coerções do discurso, a noção de cenografia afigura-se como a cena enunciativa caracteristicamente mais inventiva do discurso. Na teorização de Maingueneau (2002 [1998]; 2001 [1993]), a construção de uma cenografia apoia-se em cenas validadas, que são cenas "já instaladas na memória coletiva, seja a título de modelos que se rejeitam ou de modelos que se valorizam", explicando que uma cena validada "não se caracteriza propriamente como discurso, mas como um estereótipo autonomizado, descontextualizado, disponível para reinvestimentos em outros textos” (Id., 2002 [1998], p. 92) e que “'validado' não significa valorizado, mas já instalado no universo de saber e de valores do público" (Id., 2001 [1993], p. 126)

Se a cenografia comporta cenas de fala calcadas em estereótipos, o que remete a modos de presença no mundo já pré-construídos, é válido dizer que comporta, igualmente, modos de sentir, o que remete a um outro tipo de cena enunciativa compreendida pela cenografia, a saber: o cenário passional.

Como as paixões estão associadas ao conjunto de crenças compartilhadas e axiologizadas historicamente por uma comunidade argumentativa (ou discursiva), a construção discursiva das paixões está mais suscetível às cenas de fala já instaladas na memória discursiva do que às regras e aos rituais impostos pelo tipo (cena englobante) e pelo gênero (cena genérica) de discurso. Assim, a dimensão passional do discurso manifesta-se, também, por meio de uma cena enunciativa passional (cenário passional), que - ao lado das cenas validadas - também apoia a construção de uma cenografia. 
Afora o aspecto enunciativo, formulamos a noção de cenário passional, inspirando-nos numa tópica das paixões, concebida por Aristóteles, no Livro II de sua Retórica, como os três pontos de vista sobre as paixões:

\begin{abstract}
Devem-se distinguir, relativamente a cada uma [das paixões], três pontos de vista, quero dizer, a respeito da cólera, por exemplo, em que disposições estão as pessoas em cólera, contra quem habitualmente se encolerizam, e por quais motivos. De fato, se conhecêssemos apenas um ou dois desses pontos de vista, mas não todos, seria impossível inspirar a cólera; o mesmo acontece com as outras paixões (ARISTÓTELES, 2000 [c.400 a.C], p. 5).
\end{abstract}

Apoiando-nos nesse trecho da Retórica, entendemos que a noção de cenário passional constitui-se com base nestes três pontos: (i) a disposição do sujeito-fonte da paixão; (ii) a disposição do sujeito-alvo da paixão; (iii) os motivos e as razões que suscitam a paixão. Em outras palavras, o cenário passional abarca a relação entre o sujeito que desperta a paixão, o sujeito que sofre a paixão e as razões que desencadeiam a paixão. É preciso notar que esses sujeitos colocam-se numa situação de interação e de troca que nos permite dizer que tal situação compõe uma cena de enunciação, uma cena enunciativa.

É importante afirmar que esses três elementos formam e são formados por um conjunto de crenças compartilhadas por todo o auditório e constituem matéria para a construção do pathos retórico. É nesse sentido que Declercq (1992, p. 54) diz que "a tipologia das paixões oratórias define uma doxa, comum ao orador que a invoca e ao auditório que a aceita"38.

Nessa perspectiva, entendemos que as paixões estão vinculadas a um conjunto de crenças compartilhadas e axiologizadas socialmente, ou seja, a um sistema de valores que determina o valor de cada paixão, conforme a circunstância em que ela é manifestada. Os sujeitos projetam no e pelo discurso imagens de si e do outro, apoiando-se também no tipo de paixões que sua cultura determina como possíveis ou não possíveis de se apresentar.

Por exemplo, em uma democracia republicana de qualquer país do mundo, um deputado que é acusado de corrupção deve reagir com veemente indignação; isso quer dizer que os sistemas de valores (da democracia republicana) impõem ao sujeito enunciador (deputado acusado) que ele, no mínimo, manifeste e desperte em

\footnotetext{
${ }^{38}$ Tradução nossa. No original: "La typologie des passions oratoires définit une doxa, commune à l'orateur qui l'invoque et à l'auditoire qui l'accepte" (Declercq, 1992, p. 54).
} 
seu coenunciador (Parlamento, opinião pública etc.) uma determinada emoção (indignação) em resposta à injustiça que sofreu.

Baseamo-nos, logo, nesses três pontos de vista sobre cada uma das paixões, para propor a noção de cenário passional, que, em síntese, compreenderia:

- A disposição do sujeito apaixonado, desdobrado em enunciador/coenunciador;

- O sujeito que é alvo da paixão, este é um referente, seria o ele e não o eu-tu;

- Os motivos desencadeadores da paixão.

Todavia, esse esquema não é tão simples quanto parece, pois há que se considerar as instâncias subjetivas da enunciação sob análise. Depreender esse tipo de cena é descrever a disposição passional dos sujeitos instalados numa dada situação de enunciação, uma cena que nem sempre será descrita somente com base na observação das instâncias subjetivas correspondentes ao enunciador e ao coenunciador, pois, ao se tratar da relação enunciado/enunciação, é preciso examinar também a disposição passional em que estão os sujeitos instalados no enunciado pelo enunciador.

O cenário passional afigura-se como uma cena enunciativa propícia à captação do imaginário passional, em que os participantes da comunicação (enunciador e coenunciador) são levados a experimentar estados passionais relacionados às paixões que Ihe são apresentadas. Tomemos, por exemplo, o júri popular como gênero discursivo: o advogado de defesa narra a biografia do acusado, apresentando-o como vítima da injustiça social e da brutalidade e da indiferença de seu pai, a fim de justificar seu comportamento de homicida, o que o levara ao tribunal. Note-se que, no nível do enunciado, esse discurso constrói um acusado que sofrera a paixão da injustiça e um pai caracterizado pela ira, ao passo que, no nível da enunciação, esse cenário passional serve à captação da piedade: tem-se, nesse caso, não o discurso da injustiça e da ira, mas sim o discurso da piedade.

É, com base nessas considerações, que acreditamos que a análise deve ter em conta esses três elementos constituintes do cenário passional (imbricados com o conjunto de crenças compartilhadas e axiologizadas socialmente), bem como os elementos linguísticos e enunciativos associados à expressão das paixões no enunciado. 
2.1.4 A indissociabilidade entre o ethos e o pathos

Esta subseção tem por objetivo abordar a indissociabilidade entre o ethos e o pathos, bem como discutir a sua relação com o sujeito discursivo, noção preconizada pela Análise do Discurso.

Assim, tão importante quanto situar a noção de pathos no quadro teórico da Análise do Discurso é considerar sua associação com a noção de ethos. E essa intersecção entre ethos e pathos já é dada na seguinte passagem do Livro I da Retórica de Aristóteles:

Três são as causas que tornam persuasivos os oradores e a sua importância é tal que por elas nos persuadimos, sem necessidade de demonstrações. São elas a prudência, a virtude e a benevolência (ARISTÓTELES, 1998 [c.400 a.C], p. 106).

Para Eggs (2005, p. 40), Aristóteles está se referindo a três razões que inspiram confiança no ouvinte: (i) a prudência (phrónesis) é revelada se os argumentos apresentados pelo orador são sábios e razoáveis, o que remete ao logos; (ii) a virtude (areté) se mostra quando o orador argumenta honesta e sinceramente, o que está ligado ao ethos; (iii) a benevolência (eúnoia) é observada se o orador se mostra solidário e amável com seus ouvintes, o que se associa ao pathos.

Declercq (1992, p. 51), por sua vez, corrobora essa leitura ao afirmar que "o ethos se articula com o pathos, pois a representação das virtudes morais induz emoções no auditório"39. Ilustremos isso, retomando um acontecimento que foi amplamente divulgado pela imprensa brasileira.

Masataka Ota, um pai que teve seu filho de oito anos sequestrado e assassinado por três vigilantes de sua própria loja, passou a visitar os criminosos na prisão para conversar, saber como eles sentiam-se, levar-lhes alimentos, dar o seu perdão. Todas essas suas ações definem traços de caráter de um indivíduo que, ao conceder entrevistas às emissoras de televisão, às rádios e aos jornais, constitui-se, do ponto de vista discursivo, em um enunciador que tem como coenunciador o público desses veículos de comunicação. As virtudes morais apresentadas por esse enunciador são valorizadas positivamente pela sociedade brasileira, que compartilha

\footnotetext{
39 Tradução nossa. No original: [...] l'ethos s'articule en effet au pathos, car la représentation des vertus morales induit des émotions chez l'auditoire.
} 
valores cristãos tais como o amor ao próximo, a resignação e o perdão; no entanto, o contexto situacional lhe é tão adverso que tais atitudes sobrevalorizam seu caráter e, consequentemente, afeta a compreensão e o julgamento do público por causar emoção.

Nessa mesma linha de raciocínio, Meyer (2000, p. XLVII) contribui da seguinte forma:

As paixões são ao mesmo tempo modos de ser (que remetem ao ethos e
determinam um caráter) e respostas a modos de ser (o ajustamento ao
outro). Daí a impressão de que as paixões nada têm de interativo, sendo
somente estados afetivos próprios da pessoa como tal. A confusão, porém,
permanece.

Para ilustrar o que estamos dizendo, recuperemos o discurso epidítico de Brutus em razão do funeral de Caio Júlio César. Brutus evoca os valores democráticos compartilhados pelos romanos para justificar os motivos que o levaram a conspirar e a participar do assassinato de César no Senado. O modo de ser de Brutus ajusta-se ao modo de ser do povo romano, que, comovido pela perda de seu líder, sente a necessidade de fazer justiça contra os responsáveis por sua morte. Em seu discurso, Brutus afirma que todos estavam diante do corpo de um grande homem que não mediu esforços para consolidar a república, e que sua morte foi necessária para que a tirania não voltasse a se instalar em Roma, ou seja, o assassinato de Júlio César se justifica em nome dos ideais propugnados pela própria vítima e comungados por toda aquela sociedade. Assim, nesse ajustamento, a paixão construída pelo discurso não seria a da cólera ou a da vingança, mas sim a da resignação, da aceitação passiva de uma perda ou um dano sem o sentimento da revolta.

Em suma, considerando que, para Aristóteles, as noções de ethos e de pathos constituem juntamente as provas subjetivas, remetendo àquilo que é próprio à dimensão subjetiva da linguagem, voltaremos nossa atenção para a influência que o pathos exerce sobre o ethos no processo de construção do discurso. Aliamos, portanto, a ideia de pathos como o conjunto de emoções causadas pelo discurso no destinatário da enunciação à ideia de pathos como dimensão discursiva que afeta a construção do ethos e, consequentemente, suas noções conexas (anti-ethos, incorporação etc.). 
Já, no que toca à questão da associação do pathos e do ethos ao sujeito do discurso, é preciso sublinhar que a abordagem discursiva dessas noções originalmente retóricas afasta-se de certas perspectivas que as concebem como partes de um jogo de estratégias arquitetadas por um orador plenamente consciente dos usos que ele faz dos recursos da linguagem para persuadir seu ouvinte, porque rejeita o sujeito consciente, intencional e centro gerador de sentidos, isto é, o sujeito em sua homogeneidade. Ao assumir as teorias que concebem o sujeito do discurso como efeito de sentido, a abordagem discursiva tende a relativizar essa visão mais técnica do ethos e do pathos, atribuindo-Ihes um estatuto pragmático, social, histórico, comunicacional, enunciativo, discursivo.

Essa perspectiva abre-se com os trabalhos de Authier-Revuz (2004 [1982], 1990), que apresenta e detalha a noção de heterogeneidade enunciativa, apoiandose (i) no conceito de dialogismo postulado por Bakhtin e (ii) na noção de sujeito e sua relação com a linguagem veiculada pela releitura de Freud feita por Lacan.

A autora distingue, em sua obra, duas formas de heterogeneidade, a saber: uma constitutiva e outra mostrada. A concepção de uma heterogeneidade constitutiva do sujeito e de seu discurso recobre a ideia de que o Outro está constitutivamente no sujeito e no seu discurso, enquanto que a noção de heterogeneidade mostrada abarca as formas que inscrevem o Outro no fio discursivo e representam a negociação do sujeito enunciador com a heterogeneidade constitutiva de seu discurso.

No que diz respeito ao sujeito, mais especificamente, essa distinção implica em que, na heterogeneidade constitutiva, o discurso é construído de modo que a “ilusão de centralidade do sujeito" pareça prevalecer, ao passo que, na heterogeneidade mostrada, essa centralidade - que é ilusória - se altere e revele de maneira explícita a presença do discurso do Outro no discurso do Mesmo. Assim, Authier-Revuz (2004 [1982], p. 69) articula sua teoria da heterogeneidade enunciativa a uma teoria do descentramento do sujeito, destacando que sujeito é um efeito de linguagem, de discurso, que não existe fora da ilusão de centralidade:

[...] para um sujeito dividido, "clivado", (e não "desdobrado") não há centro, de onde emanariam em particular o sentido e a fala, fora da ilusão do fantasma; mas manter esta ilusão de um centro é a função necessária e normal do eu para o sujeito. 
A perspectiva enunciativa de Authier-Revuz não se distancia da abordagem materialista desenvolvida por Michel Pêcheux (1997, p. 129), que, ao distinguir entre concepção idealista e concepção materialista do sujeito, aponta que o erro central da visão idealista consiste em:

[...] considerar as ideologias como idéias e não como forças materiais e [...] em conceber que elas têm sua origem nos sujeitos, quando na verdade elas 'constituem os indivíduos em sujeitos', para retomar a expressão de L. Althusser".

Em consonância com as formulações de Pêcheux, Eni Orlandi (2007, p. 11) procura enfatizar também que a língua é o meio de constituição desse sujeito, argumentando que "ao inscrever-se na língua o indivíduo é interpelado em sujeito pela ideologia, daí resultando uma forma sujeito histórica".

Igualmente, Brandão (2004, p. 83) corrobora esse ponto de vista ao afirmar que:

[...] há uma heterogeneidade que é constitutiva do próprio discurso e que é produzida pela dispersão do sujeito. Essa heterogeneidade, entretanto, é trabalhada pelo locutor de tal forma que, impulsionado por uma "vontade totalizante" faz com que o texto adquira, na forma de um concerto polifônico, uma unidade, uma coerência, quer harmonizando as diferentes vozes, quer "apagando" as vozes discordantes.

Assim, de certo modo, o ethos e o pathos são noções que tendem a reforçar a ilusão de centralidade desse sujeito do discurso, uma vez que o ethos está associado à imagem do enunciador, da instância subjetiva responsável pela enunciação do discurso, enquanto que o pathos está relacionado com as emoções provocadas pelo enunciador em seu coenunciador, o que faz ressaltar o efeito de sentido de individuação dos participantes da enunciação. Todavia, em Análise do Discurso, ethos e pathos só podem ser entendidos como efeitos de sentido vinculados a um sujeito do discurso cindido e descentrado: ethos e pathos reforçam os traços de identificação do sujeito, mas somente são construídos por meio daquilo que é constitutivamente discursivo. 


\subsection{A primeira página do jornal: um hipergênero do discurso}

\subsubsection{Localizando os problemas da primeira página do jornal}

A partir dos resultados de nosso artigo "Análise do Discurso e leitura de gêneros do jornal: uma experiência com o programa Teia do Saber", publicado em 2008, percebemos que nossa proposta de análise de primeira página jornalística não seria adequada se tomássemos os textos de forma isolada, pois, ainda que seja levada em conta a situação de enunciação de cada texto, bem como o seu contexto sócio-histórico, o mesmo seria abordado de maneira desvinculada à sua própria concepção genérica.

Embora, naquele momento, já estivéssemos preocupados com a importância do layout na construção dos sentidos de cada texto da página, não estávamos ainda voltados para o problema da natureza genérica da primeira página jornalística. E, durante o processo de constituição do corpus da pesquisa, tal problema voltou à tona, pois, apesar da grande diferença entre os jornais atuais e os da década de 1960, as primeiras páginas das edições de abril de 1964 do Correio da Manhã e d'O Globo apresentam fortes evidências de que elas possam ser um gênero de discurso constituído a partir de outros gêneros. Assim, ao refletir sobre a natureza da primeira página, levantamos a hipótese de que tal página pudesse ser um gênero de discurso, um hipergênero de discurso ou apenas um suporte aos gêneros de discurso.

Procedemos, a partir dessas reflexões, a uma pesquisa bibliográfica, a fim de localizar estudos sobre a condição genérica da primeira página jornalística. E, apesar de não termos encontrado nenhuma publicação de referência que se dedicasse a essa questão de maneira específica, observamos que é a partir de 2005 que começam a surgir, nas grandes áreas de Letras e de Comunicação, os primeiros trabalhos que tomam a primeira página como um gênero de discurso, e não mais apenas como suporte de um gênero ou "espelho" do jornal.

Dentre os trabalhos encontrados, o primeiro é a tese de doutorado intitulada Compreensão ativa e criadora: uma proposta de ensino-aprendizagem de leitura do jornal impresso, em que Paes de Barros (2005) desenvolveu um projeto de leitura com alunos de oitava série do Ensino Fundamental, utilizando a primeira página de jornal impresso como um instrumento de ensino-aprendizagem de leitura. Vejamos duas passagens em que a autora define seu objeto de estudo e de aplicação: 
De modo semelhante, ocorre com a primeira página do jornal impresso: seus gêneros intercalados, dispostos em uma determinada disposição gráfico-editorial, compõem-se - com fotografias, ilustrações, infográficos e textos escritos em outros gêneros - num todo unificado de sentido, configurando um gênero discursivo (op. cit., p. 71).

Em outras palavras, o que se propõe é uma reelaboração do trabalho com os gêneros discursivos, enfocada por outro aspecto: partindo do ponto de vista de um trabalho que tome o jornal não somente como um suporte onde são veiculados textos em gêneros diversos, mas como um sistema de gêneros composto por gêneros intercalados e a primeira página considerada como um gênero multimodal, onde os vários gêneros intercalados (verbais e não-verbais) estão sempre em diálogo entre si [...] (op. cit., p. 95).

Além da tese de Paes de Barros (2005), que avança no sentido de conceber a primeira página não como mero suporte, mas como gênero discursivo, levantamos a dissertação de mestrado Os significados composicionais e a formação de subjetividades na primeira página de jornais mineiros: um estudo de caso à luz da gramática do design visual, em que Carvalho (2007, p. 14) investiga "que significados sociais são representados na estrutura do layout da primeira página dos jornais mineiros de maior circulação no estado".

No mais, a pesquisa bibliográfica voltada à primeira página como gênero de discurso localizou somente algumas comunicações de trabalho apresentadas em eventos acadêmicos. Em 2007, no 6o InPLA (Intercâmbio de Pesquisas em Lingüística Aplicada), realizado na PUC/São Paulo, a exposição de Anderson Salvaterra Magalhães intitulada "Concepções de trabalho e a organização identitária de São Paulo: um enfoque dialógico-enunciativo da construção dos sentidos em primeiras páginas da Folha de S. Paulo" situou-se numa perspectiva de linguagem que configurou a primeira página dos jornais abordados como "um gênero discursivo de natureza verbo-visual que reflete e refrata discursos e sentidos relevantes para a construção de facetas identitárias de São Paulo".

Também em 2007, no 4ํ SIGET (Simpósio Internacional de Estudos de Gêneros Textuais), realizado na Unisul, dois trabalhos sobre o tema foram inscritos. Em sua comunicação intitulada "Aspectos multimodais em hipertextos impressos e virtuais", Ana Christina Souto Maior apresentou sua pesquisa que buscou "comparar aspectos multimodais em mídias impressas e virtuais, em primeira página de jornais e de provedores, e caracterizá-los de acordo com seus suportes e gêneros constitutivos". Por sua vez, em "O gênero primeira página de jornais sob a perspectiva da análise multimodal", Flaviane Faria Carvalho expôs um trabalho que 
visou "contribuir para a análise do gênero primeira página dos jornais de maior circulação em Minas Gerais: o Estado de Minas e o Super Notícia, focalizando inicialmente a descrição dos significados construídos nestas páginas”.

Mais adiante, em 2009, no XIII Congresso Nacional de Linguística e Filologia, realizado na UERJ, Suzana Lima Vargas e outros comunicam o trabalho "O ensino do gênero primeira página de jornal: a aquisição dos conhecimentos textuais e gramaticais". Tal comunicação não gerou publicação.

Entretanto, se não há na literatura registro de publicações que focalizem a primeira página jornalística como gênero discursivo, há uma série de trabalhos que, embora toquem transversalmente no problema que estamos colocando em foco, irão inspirar as considerações que teceremos mais adiante. É importante que façamos também uma breve apresentação dessas pesquisas.

Revendo os quadros teóricos dos modelos de comunicação política na imprensa e na televisão, Heloiza Helena Gomes de Matos (1989) compara os temas da propaganda oficial na televisão e na imprensa com o noticiário de primeira página dos jornais $O$ Estado de São Paulo e O Globo, a fim de mostrar a presença do discurso autoritário na imprensa brasileira entre 1969 e 1974.

Por sua vez, Lineide Salvador Mosca (1990), trabalhando numa perspectiva retórico-argumentativa, trata dos processos de adjetivação na construção da subjetividade no editorial jornalístico. Dentre seus objetivos e suas contribuições, o que podemos destacar e trazer para nossa pesquisa é que o referido estudo reconhece a página de opinião como um todo de sentido, pois, ao examinar os editoriais, abarca também os gêneros que compõem a página, tais como a charge, a carta do leitor, a crônica etc., compreendendo-os como gêneros pertencentes ao jornalismo opinativo, ou melhor, gêneros que criam efeito de "opinatividade" (op. cit., p. 83).

Sob a perspectiva da Análise do Discurso, dita de orientação francesa, Anna Maria Grammatico Carmagnani (1996) constitui um corpus com base nas primeiras páginas de três jornais brasileiros (O Estado de São Paulo, Folha de São Paulo e Diário Popular, atual Diário de São Paulo) e três jornais ingleses (Daily Telegraph, The Guardian e Daily Mail), a fim de verificar os meios utilizados pelos jornais para homogeneizar sentidos e as técnicas de argumentação utilizadas para persuadir o leitor da veracidade dos fatos relatados (op. cit., p. 101-102). 
É interessante notar que a autora aponta uma diferença entre as primeiras páginas dos jornais dos dois países, pois de acordo com o corpus de sua pesquisa, entende que a primeira página nos jornais brasileiros é o "local privilegiado da editoria geral para a apresentação dos resumos das notícias mais importantes", ao passo que, nos jornais ingleses, é "o local indicado para o início das matérias consideradas prioritárias naquela edição". Talvez a diferença entre as primeiras páginas dos jornais pesquisados seja mínima, limitando-se a uma questão de estilo, todavia vale destacar que, em todos os casos, o objetivo é o mesmo: "apresentar apenas os fatos, reservando às páginas internas os textos opinativos" (op. cit., p. 110).

Em seu artigo intitulado "O percurso interpretativo de um discurso argumentativo", Mauro (1997) discute as estratégias de construção do sentido de um discurso argumentativo, especificamente o artigo assinado da página editorial do jornal. À nossa pesquisa, interessa muito a perspectiva apresentada por Mauro (1997, p. 80), uma vez que a autora concebe a página editorial do jornal como uma cena enunciativa:

O artigo assinado da página editorial caracteriza-se como um discurso de natureza argumentativa que, ao lado do editorial, configura o espaço discursivo conferido à opinião, no cenário enunciativo composto por esta página do jornal [grifo nosso].

Do ponto de vista da Semiótica Discursiva, Norma Discini (2003) empreende um trabalho destinado a investigar a construção do estilo e do ethos, dedicando um capítulo à análise das primeiras páginas dos diários Folha de São Paulo, O Estado de São Paulo e o extinto Notícias Populares.

Numa abordagem editorial, José Ferreira Júnior (2003) analisa a primeira página jornalística descrevendo as alterações gráfico-visuais promovidas pelos diários Jornal do Brasil, Jornal da Tarde e Correio Braziliense ao curso da segunda metade do século $X X$.

Orientadas pelos trabalhos de Gunther Kress \& Theo van Leeuwen (1996, 1998), Carvalho \& Magalhães (2009) discorrem, em um artigo publicado na Revista da ANPOLL, sobre o layout da primeira página de jornais mineiros. Nessa perspectiva de trabalho, a primeira página do jornal não é abordada com as propriedades de um gênero de discurso, mas, ao dizer que "o layout aloca os vários 
elementos de sentido dentro de um todo, e provê ordem e coerência entre eles"40, oferece-nos subsídios para a análise da composição da primeira página como uma unidade de sentido verbo-visual.

De partida, podemos assumir que a primeira página do jornal caracteriza-se como um enunciado do tipo verbo-visual não somente em razão de conter imagens fotográficas, por exemplo, mas, sobretudo, porque é preciso considerar, em sua composição, elementos tais como o espaço ocupado pelo texto na página do jornal, a disposição dos textos em colunas, a preferência por um determinado gênero de discurso na distribuição e na diagramação da página, a inter-relação entre os textos da página, a maior ou menor presença de material verbal ou visual na página, a maior ou menor recorrência ao uso de títulos e subtítulos, a presença ou a ausência de chamadas para aprofundamento da notícia, o índice etc.

Há um princípio que rege o enunciado verbo-visual, assim como os enunciados verbo-sonoro, verbo-musical etc. A materialidade linguística unida à outra materialidade (visual, sonora, musical etc.) constitui apenas um enunciado, e não dois ou mais. Assim, a análise desse tipo de enunciado não se limita a meramente estabelecer correlações entre o verbal e o não-verbal como se fossem unidades autônomas de sentido que mantêm relações entre si, pois esse tipo de enunciado constitui-se como um todo de sentido.

É nesse sentido que Fiorin (2006, p. 3) entende as semióticas sincréticas, mostrando que, na trajetória da humanidade:

[...] pouco a pouco, vão surgindo outras maneiras de expressar os sentidos, vão sendo elaboradas outras linguagens. Ao lado das linguagens "simples", que se manifestam por um único meio de expressão, como a música ou a escrita alfabética, engendram-se linguagens "complexas", que se externam por diversos meios de expressão.

Especificamente sobre a página jornalística, encontramos no trabalho de Brait (1999, p. 340) aportes que sustentam o ponto de vista exposto até o momento. Apesar da extensão da citação, vale acompanhar a explicação da autora:

[...] do plano de expressão dos diversos gêneros que compõem o discurso jornalístico participam a linguagem verbal e a visual, de forma que a natureza desse discurso implica, necessariamente, a conjunção verbovisual, configurada não apenas pelas especificidades dos diferentes segmentos verbais e visuais, mas especialmente pelo projeto gráfico, pela

\footnotetext{
${ }^{40}$ Tradução nossa. No original: "Layout places the various meaningful elements into the whole, and provides ordering and coherence among them" (KRESS; LEEUWEN, 1998, p. 200).
} 
diagramação que constitui o texto enquanto unidade significativa; isso significa que o espaço ocupado pelos diferentes segmentos de uma seqüência textual também assume uma dimensão significativa, o que não é novidade levando-se em conta toda a tradição, ao menos ocidental, de leitura e simbolização dos espaços envolvidos na moldura de uma composição visual.

E, mais precisamente ainda sobre a primeira página do jornal, Kress \& Leeuwen (1998, p. 187) tratam "as primeiras páginas como signos (complexos), que propõem e exigem uma leitura inicial como um signo" ${ }^{\text {"11. }}$.

Em síntese, o que pudemos perceber nos trabalhos levantados nesta pesquisa é que a primeira página não é apenas um mero suporte veiculador de textos, mas sim um dispositivo de enunciação que, além de definir o jornal e seu leitor como instâncias subjetivas, construindo, nesse processo, a identificação entre essas duas instâncias, organiza e homogeneíza os sentidos construídos e manifestados por meio dos diversos gêneros discursivos que se intercalam e se inter-relacionam na primeira página, constituindo-se, portanto, como uma cena de enunciação.

Todavia, não basta compreender a primeira página como um gênero do discurso, pois ela extrapola isso. Assim, em nossa pesquisa bibliográfica, pudemos encontrar em Bonini (2003) e em Maingueneau (2004) formulações teóricas sobre a noção de hipergênero capazes de lançar luz sobre a definição da primeira página jornalística.

Discutiremos aqui tais propostas, a fim de fazer as adequações pertinentes ao nosso quadro teórico. Antes, situaremos a concepção de gênero de discurso assumida neste trabalho, pois, embora não seja nosso objetivo discorrer sobre os problemas em torno dessa noção, encaramos a compreensão dos gêneros encontrados em nosso corpus como uma das tarefas desta pesquisa.

\footnotetext{
${ }^{41}$ Tradução nossa. No original: "[...] we treat front pages as (complex) signs, which invite and require an initial reading as one sign" (KRESS; LEEUWEN, 1998, p. 187-188).
} 


\subsubsection{Tipologias genéricas, hipergênero e cenas de enunciação}

As características constitutivas dos textos e as tentativas de classificá-los em famílias são preocupações que já se fazem presentes desde Platão e Aristóteles, os quais inauguraram o que viria a se tornar uma longa tradição nos estudos literários e retóricos: o primeiro distinguira os gêneros literários em lírico, épico e dramático, enquanto o segundo concebera os gêneros retóricos em deliberativo, judicial e epidítico. As revoluções provocadas durante a Idade Média e a Idade Moderna expandiram as possibilidades de comunicação, propiciando a ramificação e a diversificação de seus dispositivos de enunciação, ou seja, dos gêneros discursivos. Iremos nos eximir de reportar a literatura sobre a evolução dos gêneros, tendo em vista que nosso objetivo é situar a concepção genérica adotada nesta pesquisa.

Restringindo-nos ao objetivo de apenas mapear as tipologias genéricas, traremos as visões de Brandão (2000), Bonini (2003), Charaudeau (2004) e Maingueneau (2004) que, apesar de suas advertências sobre a construção de tipologias genéricas, assumiram o risco de esboçá-las.

Assim, Brandão (2000, p. 23) apresenta quatro tipos de classificações, a saber:

- As tipologias funcionais, fundadas sobre o estudo das funções dos discursos (na perspectiva de Bühler e Jakobson, 1963);

- As tipologias enunciativas que tratam principalmente da influência das condições de enunciação (interlocutores, lugar e tempo) sobre a organização discursiva (aqui se incluem os modelos inspirados por Benveniste, 1966 e o trabalho de Bronckart et al, 1985);

- As tipologias cognitivas, que tratam principalmente da organização cognitiva, pré-linguística, subjacente à organização de certas sequências - narrativa, descrita etc. (nesse grupo estaria o modelo de Adam, 1987);

- A tipologia sócio-interacionista de Bakhtin (1992).

Voltado para a questão da metodologia de estudos dos gêneros, Bonini (2003) destaca três tradições de pesquisas:

- A enunciativa, representada por Adam (1999), Bronckart (1997) e Maingueneau (1998);

- A de corpus, representada por Biber (1998); 
- A etnográfica, tal como postulada por Swales (1990), Bhatia (1993) e Askehave \& Swales (2001).

Charaudeau (2004, p. 14-15), preocupado com o que ele chama de "atividade linguageira", apresenta sua revisão tipológica com base nas diferentes formas de abordar a noção de gênero:

- Segundo as grandes "funções" de base da atividade linguageira, [...] são as funções bem conhecidas de Jakobson (1963) (emotiva, conativa, fática, poética, referencial e metalinguística) ou de Halliday (1973, 1974), (instrumental, interacional, pessoal, heurística, imaginativa, "ideacional", interpessoal etc.)

- São as que se fundem na "natureza comunicacional" da troca verbal, segundo a qual, conforme Bakhtin (1984), esta é "natural", espontânea (gêneros primeiros), ou "construída", institucionalizada (gêneros segundos);

- São as que se apóiam no "aparelho formal da enunciação", como propôs Benveniste (1969);

- Outras que tentam definir os "tipos de atividade linguageira", tendo um valor mais ou menos prototípico, tais como o narrativo, o argumentativo, o explicativo, o descritivo etc.

- Outras que descrevem as características formais dos textos e reúnem neles as marcas as mais recorrentes para concluir na determinação de um gênero textual;

- Aquelas que procuram determinar um domínio de produção de discursos segundo os textos fundadores (CHARAUDEAU, 2004, p. 14).

Para esse autor, as tipologias diferem-se ao privilegiar aspectos diversos dos gêneros, tais como a ancoragem social do discurso, sua natureza comunicacional, a atividade linguageira, suas características formais etc. Charaudeau (2004) entende, porém, que tais diferenças são aspectos não excludentes dos gêneros, propondo, assim, que as mesmas sejam tomadas de forma articulada, e não separadamente.

Concluindo esse nosso breve mapeamento, resumiremos as tipologias apresentadas por Maingueneau (2004). Esse autor, ao afirmar que "há classificações de gêneros que são estabelecidas pelos usuários e outras que são elaboradas por pesquisadores" (p. 45), declara interesse sobre as tipologias do segundo grupo. Destaca, assim, que há tipologias fundadas com base em: 
- Critérios linguísticos, fundados na enunciação, na distribuição estatística das marcas linguísticas e na organização textual;

- Critérios funcionais (textos com intencionalidade lúdica, didática etc.);

- Critérios situacionais: o tipo de atores que estão implicados, as circunstâncias da comunicação, o canal utilizado etc.;

- Aquelas que combinam critérios linguísticos, funcionais e situacionais.

É possível notar que Maingueneau (2004) não dá ênfase à tipologização dos gêneros, uma vez que o autor exime-se de localizar em seu texto os autores e suas perspectivas de abordagem do gênero. No entanto, Maingueneau (p. 45) diz que a Análise do Discurso adota os critérios situacionais para abordar o gênero de discurso, os quais são "caracterizados por parâmetros tais como os papéis dos participantes, suas finalidades, seu médium, seu enquadramento espaço-temporal, o tipo de organização textual que eles implicam etc.".

Dentre as tipologias apresentadas por Brandão (2000), Charaudeau (2004) e Maingueneau (2004), nossas reflexões sobre esse tema enveredam-se pela concepção de gênero postulada por Bakhtin (2003), pois a esta subjaz uma concepção sociointeracionista de língua e de linguagem, que vai ao encontro dos pressupostos teóricos que fundamentam a abordagem discursivo-argumentativa.

Os postulados do Círculo representam, como mostra Brandão (2004, p. 8), a passagem de uma "concepção de signo linguístico como um 'sinal' inerte que advém da análise da língua como sistema sincrônico abstrato" a uma concepção de signo dialético, vivo e dinâmico. Nessa perspectiva, Bakhtin (2003, p. 261) associa o emprego da língua às formas de enunciados, os gêneros do discurso, ao postular que "o emprego da língua efetua-se em forma de enunciados (orais e escritos) concretos e únicos, proferidos pelos integrantes desse ou daquele campo da atividade humana".

É interessante notar que a teoria bakhtiniana foi elaborada em meados do século $\mathrm{XX}$, antes mesmo de toda a revolução tecnológica experimentada dos anos 1960 em diante. Assim, poderíamos nos indagar sobre a atualidade dos postulados do Círculo quanto à abordagem de gêneros da contemporaneidade, caracteristicamente constituídos por meio de semióticas diversas, tais como a primeira página do jornal. Todavia, Grillo $(2009$, p. 216) ressalta a aplicabilidade dessa teoria a enunciados do tipo verbo-visual, esclarecendo que, "embora este não tenha sido o objeto de estudo privilegiado do Círculo de Bakhtin", é possível 
entrever, em sua obra, "a noção de enunciado ou texto como unidade constituída de signos diversos":

O texto "subentendido". Se entendido o texto no sentido amplo como qualquer conjunto coerente de signos, a ciência das artes (a musicologia, a teoria e a história das artes plásticas) opera com textos (obras de arte). São pensamentos sobre pensamentos, vivências das vivências, palavras sobre palavras, textos sobre textos (BAKHTIN ${ }^{42}$, 2003a apud GRILLO, 2009, p. 216).

Em segundo lugar, é preciso ter em conta que a transformação sofrida pelos gêneros de discurso nessas últimas décadas já fora presumida por Bakhtin em sua notória formulação sobre gêneros primários e gêneros secundários.

Acompanhemos as palavras do próprio autor:

Os gêneros discursivos secundários (complexos - romances, dramas, pesquisas científicas de toda espécie, os grandes gêneros publicísticos etc.) surgem nas condições de um convívio cultural mais complexo e relativamente muito desenvolvido e organizado (predominantemente 0 escrito) [...]. No processo de sua formação eles incorporam e reelaboram diversos gêneros primários (simples), que se formaram nas condições da comunicação discursiva imediata. Esses gêneros primários, que integram os complexos, aí se transformam e adquirem um caráter especial: perdem o vínculo imediato com a realidade concreta e os enunciados reais alheios [...] (BAKHTIN, 2003, p. 263).

Assim, Bakhtin (2003) considera os gêneros de discurso sempre no bojo da interação verbal, sendo que os gêneros primários caracterizam-se pelo surgimento nas condições da comunicação discursiva imediata, ao passo que os gêneros secundários caracterizam-se pela midiatização do discurso. Com o avanço tecnológico, essa complexidade dos gêneros secundários potencializou-se de tal maneira que podemos encontrar, nos atuais meios de comunicação, formas de enunciados que chegam a ser confundidos com o seu próprio suporte.

Passemos, pois, à problemática em torno da noção de hipergênero. Tributário às concepções bakhtinianas de enunciado e de gênero do discurso, Adair Bonini (2001, 2004, 2008) formula a noção de hipergênero, o que nos auxilia na compreensão dessas formas complexas de enunciado presentes, sobretudo, nos meios de comunicação.

\footnotetext{
${ }^{42}$ BAKHTIN, Mikhail. O problema do texto em linguística, em filologia e em outras ciências humanas. In: 2003a. p. 307-335.

. Estética da criação verbal. Tradução de Paulo Bezerra. São Paulo: Martins Fontes,
} 
Resultado de uma construção teórica maturada, Bonini (2008, p. 35) explana, brevemente, o seu percurso teórico até chegar a uma concepção da noção de hipergênero, especialmente a ser aplicada ao jornal. Vejamos:

Como já havia feito em Bonini (2004), opto aqui também pelo conceito de enunciado como base da noção de gênero. Embora eu tenha trabalhado em muitos textos com a literatura proveniente da sócio-retórica, o conceito de ação de linguagem de Miller (1984) não me parece tão pertinente como unidade básica da linguagem quanto o conceito de enunciado de Bakhtin (1953), uma vez que esse último alcança uma caracterização mais plausível como unidade no fluxo da linguagem e como aspecto do comportamento comunicativo e interacional humano. Afirmei, no primeiro texto em que tratei do assunto, que: "Embora na literatura sobre gêneros textuais, o jornal seja caracterizado basicamente como um veículo, [há] motivos para considerá-lo um gênero que abriga outros (ou seja, um hipergênero), porque preenche quesitos como propósitos comunicativos próprios, organização textual característica [...] e produtores e receptores definidos" (BONINI, 2001). [...]. Em 2005, afirmei que o hipergênero (por exemplo, o jornal) poderia equivaler ao suporte de textos, mas que nem todo suporte seria um hipergênero (por exemplo, um álbum de fotografias). Neste texto mais recente (BONINI, mimeo), opto pelo termo mídia, por já ser corrente, na literatura acadêmica e na sociedade, desconsiderando o termo suporte. Mantenho, contudo, a mesma hipótese para a relação entre o gênero e seu meio de circulação.

Bonini (2008, p. 35-36) considera, portanto, o jornal como um hipergênero (um gênero que abriga outros gêneros) e também como um suporte ou mídia, ressalvando que nem todo suporte/mídia pode se comportar como um hipergênero, a exemplo da televisão, que é uma mídia composta por hipergêneros (telejornal, talkshow etc.) e gêneros (anúncio, vinheta etc.).

Não obstante, Maingueneau (2004, p. 54) também trata da noção de hipergênero, compreendendo-a como um protótipo genérico, que corresponderia a uma categoria de classificação de gêneros de discurso, um hiperônimo, não possuindo, assim, o mesmo estatuto de um gênero discursivo. Segundo o analista:

São caracterizações como "diálogo", "carta", "ensaio", "jornal" etc. que permitem formatar o texto. Não se trata, como o gênero de discurso, de um dispositivo de comunicação historicamente definido, mas um modo de organização textual com restrições fracas, que encontramos em épocas e em lugares diversos e no interior do qual encenações de fala diversificadas podem se desenvolver.

É possível notar que os dois pesquisadores convergem para uma mesma noção de hipergênero, pois partem da mesma concepção bakhtiniana de gênero do discurso, identificam problemas semelhantes e oferecem o exemplo coincidente do jornal. A contribuição de Maingueneau (2004) para o nosso trabalho deve-se ao fato 
de o autor suscitar a questão das cenas enunciativas, ao tocar na questão das encenações de fala desenvolvidas no interior do hipergênero.

Desse modo, vale acrescentar a essa discussão conduzida por Bonini (2008) o problema da cena de enunciação, que pode ser encarada, mais apropriadamente, como um fenômeno de passagens entre cenas enunciativas, conforme o foco da leitura é dirigido ao gênero ou ao hipergênero. Analisando o Correio da Manhã e $O$ Globo, podemos notar gêneros inter-relacionados e dispostos em uma mesma cena de enunciação: a da primeira página do jornal.

O caráter interativo da atividade linguageira estabelece durante a enunciação um conjunto de elementos que compõem sua própria situação de comunicação como uma cena, mais especificamente uma cena de enunciação composta pelo lugar social assumido pelo destinador do discurso, pelo lugar social atribuído ao destinatário do discurso, pelo espaço e pelo momento que são próprios a esses lugares reconhecidos socialmente. A cena é o quadro da enunciação, mas não um quadro que é dado a priori, independentemente da enunciação de seu discurso, mas constitutivo dele.

Retomemos a formulação de Maingueneau (2002 [1998], p. 85) a respeito da composição da cena de enunciação em três cenas, a saber: a cena englobante, que corresponde ao tipo de discurso (político, jurídico, literário, familiar, científico, religioso etc.); a cena genérica, que se instala por meio do gênero discursivo; a cenografia, que é a cena com que o coenunciador toma contato mais explicitamente, deslocando as duas primeiras cenas (o quadro cênico) para um segundo plano.

No caso da primeira página, estamos diante de um hipergênero que, a depender do regime de leitura, pode projetar duas cenas de enunciação, sendo uma hipergenérica e outra genérica. A esse respeito, Grillo (2004, p. 67) mostra que:

\footnotetext{
Decorrente da exploração dos aspectos visuais, a página do jornal propicia uma leitura a duas velocidades. A primeira, mais veloz e imediata, corresponde à leitura dos títulos, fotografias e legendas, na maneira como eles estão organizados na superfície da página. [...]. A segunda, mais lenta, corresponde à leitura dos "textos".
}

Assim, determinado pela disposição da manchete, dos títulos, das fotosmanchetes, das fotos-legendas na composição da página, o regime de leitura superficial da primeira página do jornal coloca em primeiro plano a cena 
hipergenérica. E essa cena enunciativa só é deslocada para um segundo plano por meio da leitura profunda, que é determinada pela leitura específica do editorial, das notícias, das notas, por meio da qual projetam-se as respectivas cenas genéricas. Há, portanto, um deslocamento entre cenas enunciativas, em que a cena instalada pela primeira página dá lugar, por exemplo, à cena instalada pelo editorial e viceversa.

Em síntese, podemos entender que a primeira página jornalística é um hipergênero discursivo, que, basicamente, pode ser entendido como um gênero de discurso constitutivamente complexo, em que sua estrutura composicional comporta outros gêneros que se inter-relacionam e colaboram para a construção, tanto da identidade discursiva do enunciador institucional (no caso, o jornal), quanto dos sentidos projetados e homogeneizados pela cena de enunciação hipergenérica. Estabelece-se, portanto, uma relação entre hipergênero e seus gêneros, em que os sujeitos do discurso são interpelados de acordo com a cena enunciativa projetada pelos diferentes regimes de leitura presentes nesse dispositivo de enunciação, ora hipergenérico, ora genérico. 


\title{
2.2.3 A primeira página e a imagem do jornal e do leitor
}

Ciro Marcondes Filho (2002, p. 24), ao detalhar a transformação do jornalismo e do jornal do século 19 para o 20 em virtude de seu ingresso no processo de industrialização, faz uma interessante consideração a respeito da primeira página:

\begin{abstract}
A notícia, como mercadoria, vai recebendo cada vez mais investimento para melhorar sua aparência e sua vendabilidade: criam-se as manchetes, os destaques, as reportagens, trabalha-se e investe-se muito mais na capa, no logotipo, nas chamadas de primeira página.
\end{abstract}

O sociólogo e jornalista trata, nesse trecho de sua obra, das novas técnicas de apresentação do texto jornalístico, advertindo, porém, que é equivocada a ideia circulante na atividade jornalística "de que o técnico é desprovido de valores" (p. 45). Nesse sentido, explica que:

[...] a opção técnica supõe uma visão de mundo, a escolha de alguns valores e a rejeição de outros; pelo técnico se impõe, em suma, um tipo de mundo que à primeira vista não deixa antever os resultados (op. cit., p. 45).

Ainda sobre a transformação do jornal, o autor soma às técnicas de paginação alterações na própria construção textual do jornal, destacando a substituição dos textos extensos pela notícia curta, bem como a contaminação das matérias longas pelo processo de aglutinação de fragmentos em detrimento da antiga construção linear da narrativa dos acontecimentos. Segundo Marcondes Filho, estamos assistindo a imposição da ideologia do flash (op. cit., p. 47)

Embora pareça que o enfoque do autor incida sobre a dimensão mercadológica do jornal, pois dedica um longo espaço de sua exposição à inserção dos jornais no processo de industrialização, Marcondes Filho (2002) volta sua preocupação para o jornalista e o leitor de jornal. Nos dois trechos a seguir, podemos ver que, para o autor, essa ideologia do flash, que nega ao leitor o fio condutor dos fatos, opera uma transformação em seu próprio modo de pensar:

[...] a opção pela transmissão a conta-gotas revela expressamente uma maneira específica de pensar, uma escolha aparentemente técnica, mas com efeitos fortemente dispersivos, do ponto de vista da narrativa. É uma opção que se coloca em oposição à "narrativa didática", ou seja, aquela que não apenas traz uma notícia mas aumenta a bagagem de informação (e, a longo prazo, de formação) do leitor (p. 44-45).

No final, restam na memória do leitor apenas sinais, traços da informação que cada segmento porventura deixou. Ele não será capaz de recordar a 
matéria que acabou de ler e nem terá o conhecimento para aplicar essa informação adquirida em outros casos semelhantes (p. 46).

Complementarmente a essa leitura de Marcondes Filho (2002), entendemos que essa ideologia do flash observada no texto do jornal opera igualmente em outras dimensões do discurso jornalístico. Nossa tese é que o que fica para o leitor é um grande material residual condensado numa forma de pensar regida pelas paixões, pois nossa experiência de leitores de jornal (de revista semanal, de espectadores de televisão e de ouvintes de rádio) nos mostra que, não importa o que ou quem seja noticiado, o leitor/espectador/ouvinte é levado, na maioria das vezes, a sentir piedade pelas vítimas e indignação pelos algozes, em que se constrói um padrão de comportamento desse leitor, massificando seu jeito de ser e de sentir, o que, do ponto de vista discursivo-argumentativo, nos convoca a trabalhar com as noções de ethos e de pathos.

Apenas para ilustrar o formato do jornal no período que Marcondes Filho (2002) chama de "primeiro jornalismo" e, depois, visualizar essa transformação pela qual passou o jornal através dos tempos, apresentaremos quatro primeiras páginas. As duas primeiras referem-se a edições que representam o nascimento da imprensa brasileira, a saber: uma do Correio Braziliense (figura 1) e outra d'A Gazeta do Rio de Janeiro (figura 2), publicadas em $1^{\circ}$ de junho e 10 de setembro de 1808, respectivamente. As duas segundas ilustram o período abordado neste trabalho: uma primeira página do jornal $O$ Estado de São Paulo e outra primeira página do jornal Folha de São Paulo.

Antes, é interessante acompanhar a observação que Isabel Lustosa (2003, p. 14-15) faz ao descrever o Correio Braziliense:

Uma curiosidade para os nossos dias é o formato desse jornal. Na verdade, não só na forma como no conteúdo, a maior parte dos jornais da virada do século XVIII para o XIX pouco se parecem com os nossos jornais de hoje. $O$ próprio papel da imprensa naquele contexto era vista de outra maneira. [...]. Naquele contexto, o jornalista se confundia com o educador. Ele via como sua missão suprir a falta de escolas e de livros através dos seus escritos jornalísticos.

Assim, não é de se estranhar que o jornal tivesse o tamanho e a forma de um livro, nem que fosse composto de longos e densos artigos onde a informação era veiculada de forma circunstanciada e analítica em textos que, às vezes, se prolongavam por vários números seguidos. 


\title{
CORREIO BRAZILIENGE
}

DE JUNHO, 1808.

\author{
Na qiarta parle posa os campoy в ra, \\ Exe uais nundu houvéra la chegara. \\ $\because$ CAMOPAS, C. VIt. e. IS.
}

\section{Introduç̧ă.}

PRAMERRO dever do homem em socicciale he ser util aos membros della; e cada um deve, segundo as shas forças Phisicas, on Moraes, adninistrar, en be. neficio da mesma, os conliecimentos, ou talentos, que a natureza, a arte, ou a educaças the prestou. O individuo, gtte abrange o bem geral d'utna sociedade, vem a ser o membro mais distincto della: as haes, que elle espalba, tîram das trevas, on da illuzaú, aquelles, que a igmorancia preripitou no babyrintho da apathia, da inepcia, $c$ do engeron. Ninguem mais util pois to que aquelle que se destina a mostrar, com evidencia, os acontecimentos do presente, e desenvolver as sombras do fucturo. Tal tem sido o trabalho dos redactores das follas pu. blicas, quando estes, munidos de uma critica saä, e de uma censura adequarla, represêntam os factos do momento, as reflexoens sobre o passado, è as soldidas conjecturas sobre o futwro.

Devem-se à Naçaó Portugueza as primeiras luzes des. tas obras, que excitain a curiosidade publica. Foi $\mathrm{em}$ Lisboa, na iniprensa de Cracsbock, emi 1649, que este Redactor trarou, com evidencia, debaixo do nome do Boletim os acontecimentos da guerra da acclamiaçaó de D. Joaó o Quario. Neste folheto se vîam os factos, taes quaes a verdade os devia pintar, e desta obra interessante sc valco, ao depois, o Concle da Ericcira, para escrever a historia da acclansaçaó com tanta censura, cacertada critica, comofez.

Figura 1 - Primeira página do Correio Braziliense, edição de 01.06.1808 


\section{GAZETA DO RIO DE JANEIRO.}

SABADO 10 DESETEMBRO DE 1808.

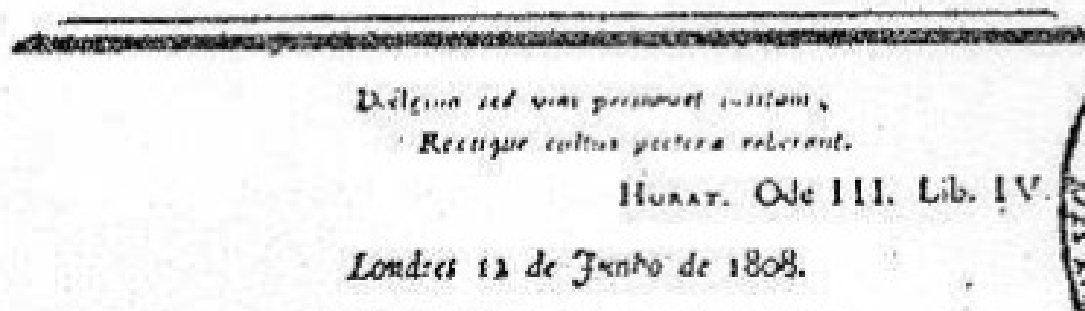

Noticias vindas por via de Fremia.

Ansterdäs to Le Alriti.

$\mathrm{O}$

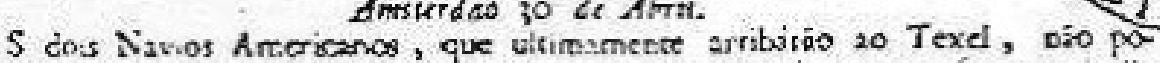

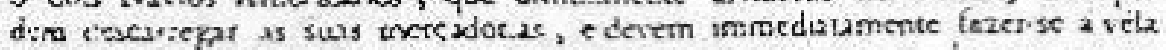
sob pera de contecaçio. Isw kem infuido muito nas pieços de vatas generous, sobre rudo por se terem hontern recebido cortas de Ftatiç2, que dizeru, que en virude ds hum Decreto Impernal sodos os Navios Arrericanos serao deridos io go que chejarem a qualquer prito di Fracga

Norscias vindas for Courntorgo.

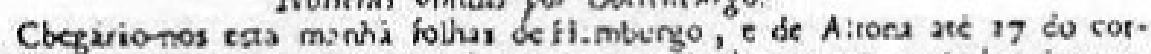
rente. Eiscas ultimas amonciao que on lanizaros em Curstintinupix ue cedsrasio con.

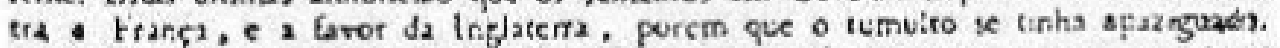

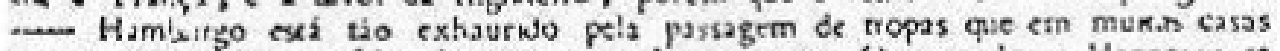
nou se achs ja huma ccjle de $p^{20}$, rem huma cama. Quest todo a Hannovet $x$

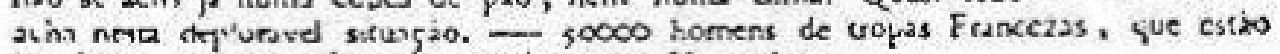
em leaia, tivivino ordem de matchat piara Hiesponha.

Londres a 16 de Jusho.

Eurate de berthe Cisia cierita a perdo da Siatira.

"Segunjo o cone nos d.sse o Official Hespanhol, que levirios a l.erd

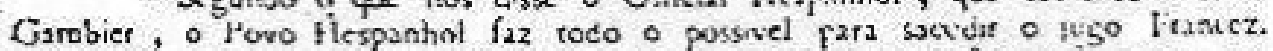

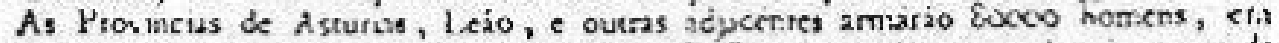
cilo numero se comprehendesn varius mell le 1 repa regulas varto de $p$, cr mo de cavallo. A Corunha declarou-se contra os frarcezes, e o ficsect se roviz thitaimkit: te sublevido a náo ci hum (ioverrador do yarudo francez- Os Ardaiczes, ras

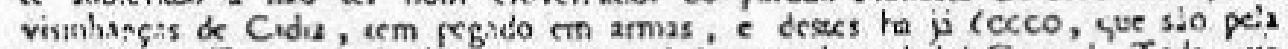
maior pa:te Tropas de Lanha. e commardados por him habil Genctal. Teda esia

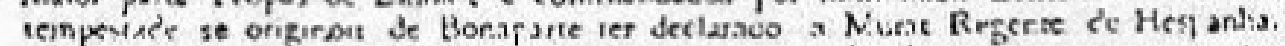

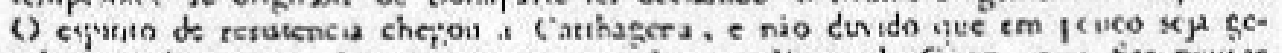
ral for wda a parte. Eppero cue nos mariem do jento de Cijon, Gue fica pelcias

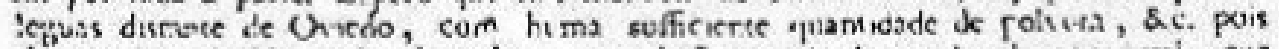

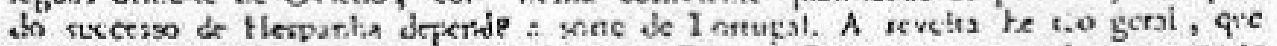

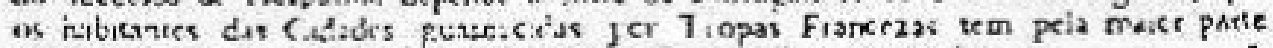

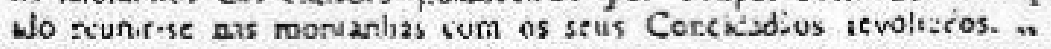

Figura 2 - Primeira página d'A Gazeta do Rio de Janeiro, edição de 10.09.1808

No que toca ao período que circunscreve o arquivo do corpus desta pesquisa, é possível notar que outros dois jornais de grande circulação nacional, embora com propostas visuais diferentes, constroem uma primeira página tal como descrita por Marcondes Filho (2002). 
Vejamos, então, os exemplos d'O Estado de São Paulo e da Folha de São Paulo:

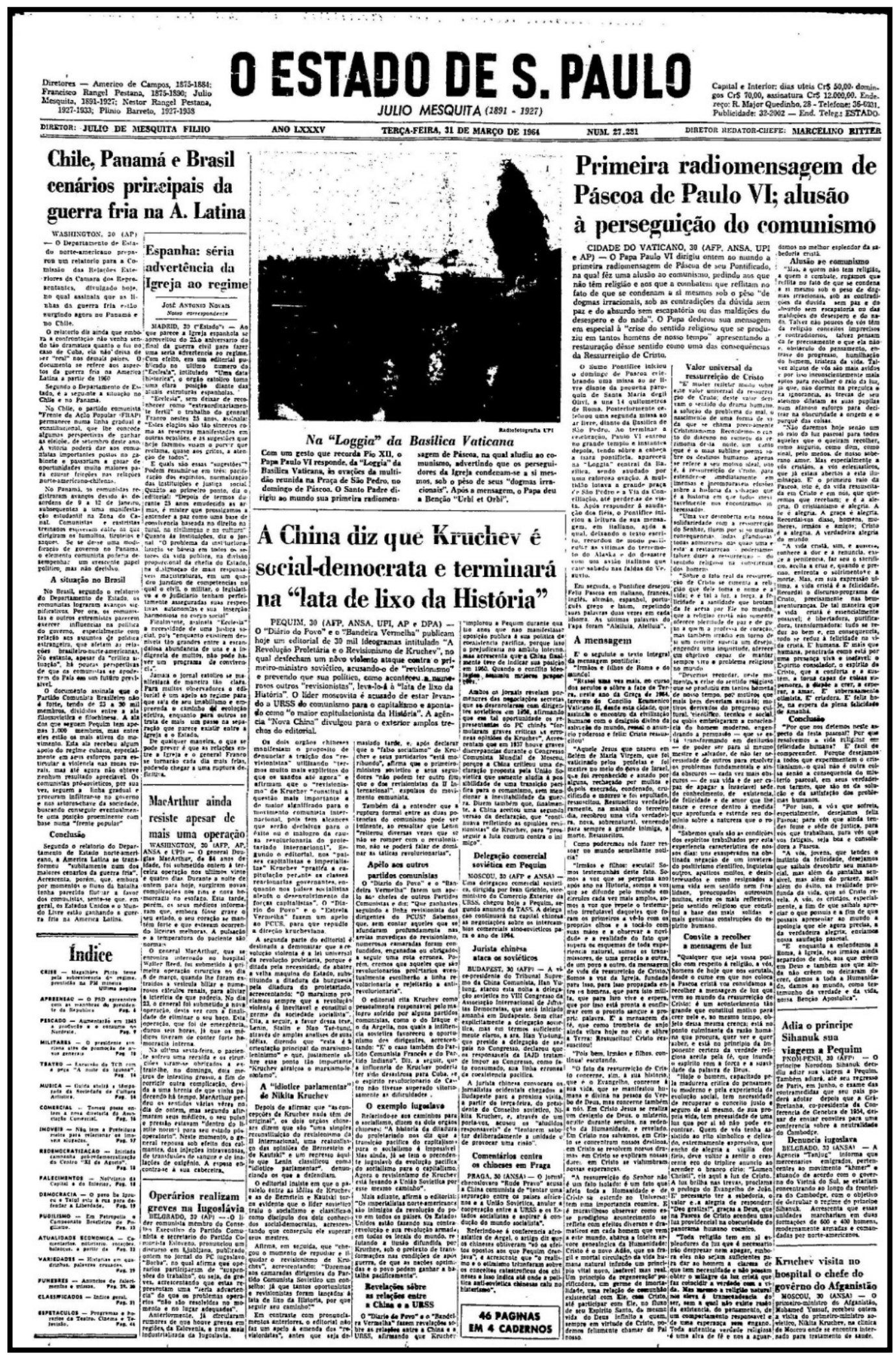

Figura 3 - Primeira página d'O Estado de São Paulo, edição de 31.03.1964 


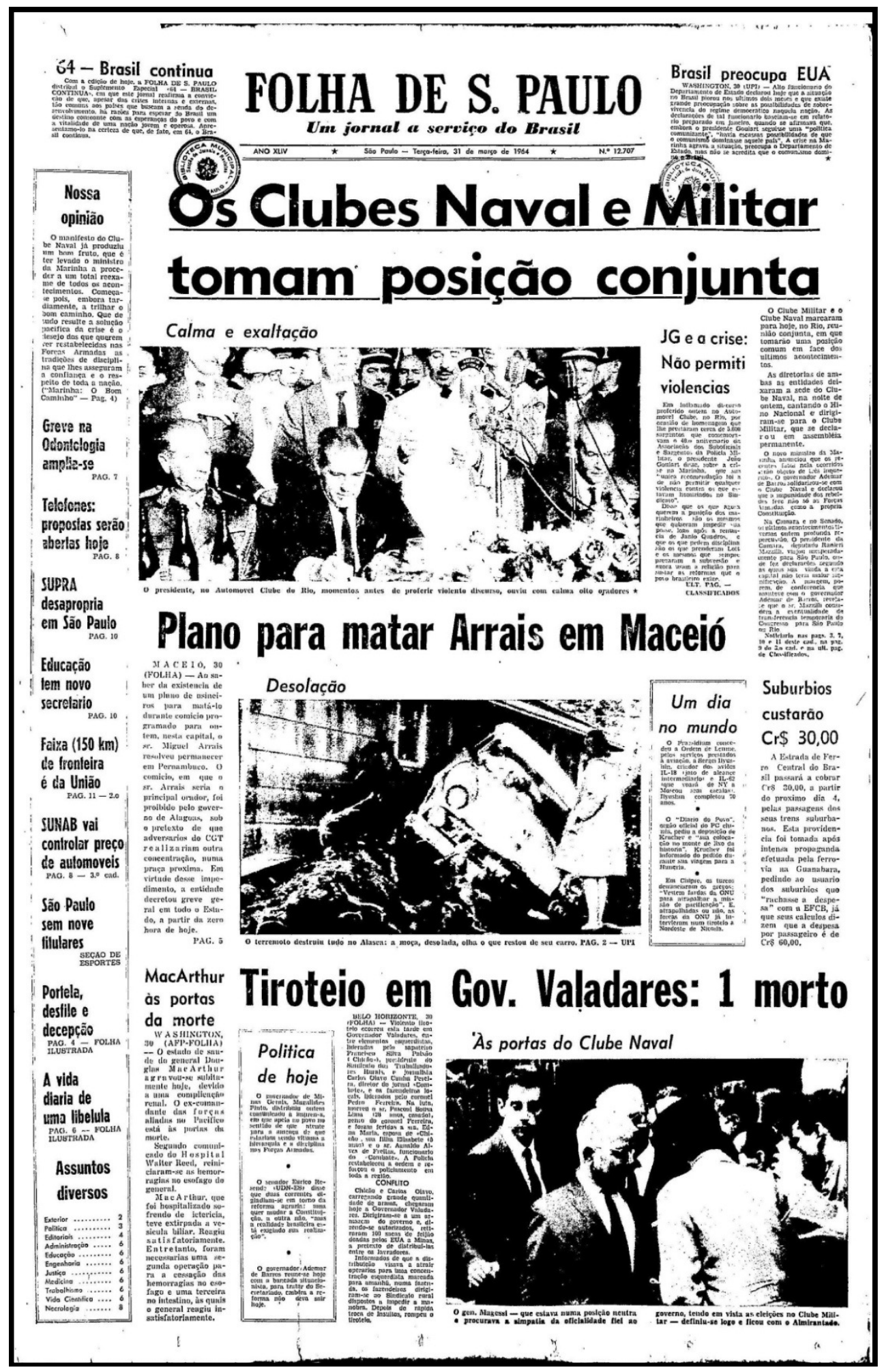

Figura 4 - Primeira página da Folha de São Paulo, edição de 31.03.1964

Podemos ver, portanto, que a construção da página jornalística e as técnicas de produção textual adotadas após a industrialização do jornal corroboram o que Marcondes Filho (2002) chama de ideologia do flash, a qual, para nós, em termos retóricos, atinge mais profundamente as dimensões do ethos e do pathos do que a 
do logos, uma vez que a página não convida o leitor a refletir sobre a informação, mas a se sensibilizar com ela.

Ressaltamos que os processos de transformação do texto jornalístico estão presentes em todas as partes do jornal, porém, pelos motivos observados em Marcondes Filho (2002), a primeira página teve tratamento diferenciado por parte da produção jornalística, recebendo investimentos visuais que potencializaram 0 alcance das estratégias próprias de uma retórica da imagem, sobretudo os efeitos de identificação.

A esse respeito, Grillo (2004, p. 50) afirma que "a configuração da primeira página é uma das grandes responsáveis pela identidade de cada órgão de imprensa". É interessante notar como o contrato midiático entre enunciador (jornal) e coenunciador (leitor do jornal) é estabelecido, uma vez que a reiteração de traços específicos da primeira página jornalística constrói a identidade visual do jornal, que, por sua vez, define o tipo do seu próprio leitor.

Basta ter em conta que a paginação (fortemente marcada pela relação entre o verbal e o visual) propõe certas opções (e não outras) de direção do olhar do leitor pela página, o que caracteriza já a orientação argumentativa do jornal, hierarquizando o valor de cada texto na página e apresentando, por meio do discurso gráfico-visual, seus próprios valores. É nesse sentido que Grillo (2004, p. 66) afirma que "a distribuição produz diferenças cujo efeito é o valor. A importância da superfície vem de que ela determina a valorização e contribui para a construção do sentido dos textos que a compõem".

Nos termos de Norma Discini (2003), que assume uma perspectiva semiótica do discurso, a primeira página é o rosto ou o espelho do jornal. Rosto, porque "cada jornal mostra uma feição própria nessa página, como chamariz ao seu leitor"; espelho, porque, "nessa primeira página, projeta-se um corpo, o corpo de cada jornal” (p. 118). Para a semioticista, esse corpo e essa feição são construídos pela recorrência diária de procedimentos, resultando na constituição do estilo de cada jornal. O estilo promove, assim, o reconhecimento recíproco entre o jornal e o seu leitor. Nas palavras de Discini (2003):

Um destinador, então, manipula um destinatário, seduzindo-o e tentando-o, para que este queira e deva entrar em conjunção com os saberes, com as informações sobre uma dada realidade (p. 118). 
Esse destinatário, discursivizado como o leitor fiel, reconhecido pelo seu jornal, e reconhecedor deste seu jornal, bem como esse destinador, discursivizado como o jornal eleito, constroem, mútua e diariamente, uma competência necessária e específica. [...]. Pelo reconhecimento recíproco, compra-se e vende-se o jornal, interagindo, para tanto, os dois atores da enunciação, enunciador e enunciatário (p. 119).

A importância da configuração da primeira página para a identidade do jornal também é mostrada por Grillo (2003), que nos oferece este relato de Alberto Dines, ex-editor-chefe do Jornal do Brasil:

The New York Times está passando por uma alteração tipográfica há anos, a fim de que ela seja tão sutil que não choque suas centenas de milhares de leitores tradicionais que exigem um jornal de fisionomia fiel a si mesmo e contínua (Dines ${ }^{43}, 1986$ apud GRILLO, 2003, p. 51).

Podemos considerar, assim, que o layout da "primeira página do jornal" é um elemento constitutivo do processo de interpelação do sujeito discursivo, apresentando-se, sobretudo, como recurso fundamental de construção da imagem dos participantes da comunicação, o jornal e seu leitor, bem como dos efeitos de identificação entre essas instâncias subjetivas da enunciação.

${ }^{43}$ DINES, Alberto. O papel do jornal: uma releitura. 6.ed. São Paulo: Summus, 1986. 


\section{PROCEDIMENTOS METODOLÓGICOS DA PESQUISA}

\subsection{Material e procedimento}

Duas instituições públicas foram determinantes para a obtenção do material desta pesquisa: Fundação Biblioteca Nacional e o Instituto de Estudos Brasileiros da USP. A primeira encarregou-se da microfilmagem dos jornais solicitados, enquanto a segunda procedeu à digitalização integral desses microfilmes, tornando sua manipulação acessível.

Entramos em contato com a Divisão de Informação Documental da Biblioteca Nacional por meio do correio eletrônico dinf@bn.br, solicitando pesquisa de todas as edições de abril de 1964 dos jornais Correio da Manhã e O Globo, bem como o orçamento para digitalização de todo o material, exceto o caderno de anúncios por não ser de interesse da pesquisa. Recebemos resposta favorável quanto à existência do material solicitado no acervo e à disponibilidade de sua reprodução. No entanto, o preço para digitalizar cada página era de $R \$ 2,00$ e, considerando que seriam trinta edições com aproximadamente trinta páginas cada um dos dois jornais, teríamos de arcar com um custo total de $R \$ 1.800,00$ para digitalização do material. Indagamos nosso contato na Biblioteca Nacional sobre uma possibilidade financeiramente mais viável de obter esse material. A pesquisadora, então, nos orientou a requerer a duplicação do rolo de microfilme em positivo (mais adequado à leitura), orçado em $R \$ 278,60$.

Aceitamos a sugestão da pesquisadora e procedemos ao pagamento das taxas por meio de uma GRU (Guia de Recolhimento da União), bem como à assinatura de um termo de responsabilidade para utilização de imagens do acervo da Fundação Biblioteca Nacional.

Após o recebimento dos rolos de microfilmes, passamos à leitura e digitalização do material. Na primeira tentativa, procuramos a Biblioteca da Faculdade de Filosofia, Letras e Ciências Humanas da USP, localizada ao lado do prédio de Letras. Encontramos lá duas máquinas para leitura de microfilmes: uma tinha interface com computador, o que permite a digitalização do microfilme e a outra máquina não tinha interface com computador, servindo para leitura ali no local, com horário agendado, bem como para impressão ao custo de $R \$ 0,70$ por página. Ocorreu, entretanto, que a primeira máquina estava fora de funcionamento porque estava sem um componente essencial, enquanto que a segunda máquina, além de 
não apresentar cópia com qualidade aceitável, reproduzia parcialmente cada imagem do microfilme. A atendente de biblioteca nos orientou, então, a procurar o IEB - Instituto de Estudos Brasileiros. No IEB, conseguimos que todo o material contido nos dois rolos fosse reproduzido de forma digital e gravado em dois volumes de DVD, Digital Versatile Disc, ao custo de dez DVDs sem uso.

Uma vez de posse do material devidamente digitalizado, pudemos ler e manusear os textos por meio do computador, utilizando um software do pacote Microsoft Office 2007, o Picture Manager, próprio para leitura e edição de imagens. Assim, pudemos imprimir o material selecionado para a pesquisa, bem como fazer os recortes necessários para a transcrição e o exame dos textos selecionados. 


\subsection{Constituição do corpus da pesquisa}

Nesta subseção, trataremos das etapas de construção do corpus da pesquisa, as quais obedecem a critérios orientados pela fundamentação teóricometodológica assumida neste trabalho.

Ao introduzir sua discussão a respeito da relação entre língua, discurso e corpus, Francine Mazière (2007, p. 14) faz a seguinte observação sobre os posicionamentos teóricos do analista do discurso no momento de definir seu corpus:

O estabelecimento de um corpus mobiliza a posição do analista sobre a
língua e seu funcionamento (escolha das formas de língua a referir e
analisar), sua posição acerca dos falantes e seu grau de autonomia
(configuração de enunciados de arquivo, ou de interlocuções), sua posição
diante das pressões impostas pelos gêneros de fala (corpus homogêneo ou
heterogêneo).

Mais adiante, Mazière (2007, p. 59-60) diz que a proposta de construção de corpus em Análise do Discurso é definida com base nas "redes de memória" (cf Courtine, 1981), o que remete, assim, a "uma construção dinâmica de corpus, móvel, gerida em interação com a progressão da análise". Conclui a autora que "[...] 0 corpus não é mais um conjunto estanque de textos, é um conjunto sem fronteira no qual o interdiscurso, exterior, irrompe no intradiscurso".

É evidente que não se trata de buscar incessantemente novos textos que proveriam o analista a cada vez que ele vislumbrasse uma nova possibilidade de interpretação de seu corpus. O ponto defendido é que o analista do discurso lança outro olhar sobre os "textos" ou os enunciados que formam seu corpus, pois, compreendendo o seu discurso e os discursos que o constituem aí, ele vê caírem as fronteiras da superfície material e física que se lhe apresentam à primeira vista em seu corpus, extrapolando, portanto, a ideia de um corpus estanque.

De forma mais concreta, essa concepção de corpus aplica-se à nossa pesquisa à medida que nos propusemos a analisar a presença dos discursos ditos "revolucionário" e "antigolpista" na produção discursiva dos jornais O Globo e Correio da Manhã publicados no mês de abril de 1964. Ora, os enunciados são atribuídos aos dois jornais, a análise recai sobre os dois jornais, logo o corpus da pesquisa é construído a partir do recorte operado sobre esses dois jornais, todavia é esse diálogo dos jornais com uma série de discursos alhures que solicita do analista outro 
olhar sobre esse corpus, tornando-o, dessa maneira, dinâmico e móvel como ressalta Mazière (2007).

Assim, o processo de construção do corpus é marcado pelo trabalho do analista sobre o corpus. Sob essa perspectiva, apoiando-se nas formulações de Courtine (1981), Marisa Grigoletto (2002, p. 63) diz que o corpus discursivo não é:

[...] um conjunto aleatório de textos que existem de forma estruturada previamente à ação do analista de discurso sobre ele; ao contrário, é o trabalho do analista, com base nas suas hipóteses de pesquisa, que constitui o corpus.

Não obstante, Grillo (2002, p. 2) orienta que a constituição de um corpus de pesquisa em Análise do Discurso deve ser realizada a partir do "recorte efetuado pelo analista na superfície discursiva o qual elabora uma seleção de formas, vistas como capazes de revelar o modo de delimitação de uma formação discursiva". E essas formas podem ser o gênero de discurso, por exemplo.

Antes, porém, de proceder a esses recortes mais finos, é preciso definir o acontecimento sobre o qual o analista irá dedicar sua atenção. Sírio Possenti (2004) repensa a noção de acontecimento discursivo, formulada no quadro teórico da Análise do Discurso por Pêcheux (1990 [1983]), a fim de abranger não apenas acontecimentos dos quais nos damos conta, mas também acontecimentos não percebidos como tais por seus contemporâneos. $\mathrm{O}$ analista brasileiro traz à baila 0 seguinte exemplo oferecido por Foucault: "a entrada e a saída de um navio são acontecimentos conhecidos e que se podem reconstruir. Mas a baixa ou o aumento dos preços é também um acontecimento" (p. 22). Nessa linha de pensamento, Possenti (2004, p. 23) argumenta que poderíamos tomar como acontecimento discursivo não só a publicação de uma obra, um manifesto etc., mas também "o estruturalismo, o feminismo, o nacionalismo", apresentando o seguinte exemplo:

Seja o caso do acontecimento feminismo, como exemplo hipotético de
diversas conseqüências; é certo que algum manifesto ou congresso pode
ser um grande acontecimento discursivo, em torno do qual se organiza um
arquivo (tudo o que se passa a dizer - ou se pode recuperar de datas
anteriores - em revistas, jornais, simpósio, livros, entrevistas, etc.). Mas há
mais: por debaixo destes, ou a seu lado, surge, por exemplo, um discurso
do corpo, da beleza, da sexualidade, do controle de natalidade, da saúde
[...].

Com base nessas orientações, construímos o corpus desta pesquisa percorrendo as seguintes etapas: 
1) Definição do acontecimento discursivo a ser abordado pela pesquisa;

2) Identificação dos discursos constituídos no seio do acontecimento discursivo;

3) Seleção e delimitação do arquivo da pesquisa;

4) Seleção do(s) gênero(s) de discurso a examinar;

5) Transcrição dos dados.

Dessa maneira, a primeira etapa da constituição do corpus da pesquisa consistiu em eleger o movimento político de abril de 1964 (chamado de "revolução" por seus apoiadores e de "golpe" por seus opositores) como o grande acontecimento discursivo, a partir do qual foram inscritos, nos mais diversos campos de atividade humana, discursos contrários e favoráveis a esse movimento, denominados aqui como discursos ditos "revolucionário" e "antigolpista". A segunda etapa é delineada, portanto, pela compreensão desses discursos inscritos no seio desse acontecimento, focalizando a relação polêmica controversa entre duas formações discursivas específicas, a saber: uma dita "revolucionária" e outra dita "antigolpista".

Organizou-se, em torno desse acontecimento discursivo, um arquivo, cuja seleção e delimitação consistiram na terceira etapa do processo de construção do corpus deste trabalho. De todo arquivo produzido em torno desse acontecimento discursivo, interessamo-nos, aqui, particularmente, por aqueles que estão relacionados à construção discursiva midiatizada, especialmente o jornal diário, sobretudo devido à sua característica paradoxal de dar publicidade aos fatos políticos ao mesmo tempo em que gere sua existência na própria política. Não da mesma forma que o discurso político, o discurso jornalístico também apresenta sua relação com o poder, a qual é explicada por Charaudeau (2007a, p. 17) assim:

[...] enquanto se admite no mundo político, de maneira geral, que o discurso aí manifestado está intimamente ligado ao poder e, por conseguinte, à manipulação, o mundo das mídias tem a pretensão de se definir contra o poder e contra a manipulação.

Ademais, a opção pela delimitação de um corpus com base no jornal diário, enquanto arquivo de um acontecimento discursivo, deve-se ao fato de que esse veículo de informação teve papel importante no processo de desestabilização do governo João Goulart e consequente desencadeamento do movimento político de abril de 1964. Dessa maneira, foi preciso determinar o segmento de mercado e os jornais a ser estudados. Elegemos, assim, jornais de grande circulação nacional, em 
razão do grau de importância desse segmento na formação da opinião pública no cenário nacional daquela época. Jornais como Folha de São Paulo, O Estado de São Paulo, Jornal do Brasil, Última Hora, O Globo, Correio da Manhã entre outros disputavam o mesmo nicho no mercado jornalístico, pois pertenciam à chamada grande imprensa, ou seja, mantinham grande tiragem, circulação nacional, colunistas renomados e público formador de opinião: fatores importantes para um jornal influenciar a opinião pública.

Desse rol, dois jornais fluminenses - O Globo e o Correio da Manhã - foram escolhidos devido à influência política ainda exercida pela antiga capital brasileira, a cidade do Rio de Janeiro, e ao posicionamento ideológico distinto entre ambos os jornais, pois, enquanto o primeiro saudava a dita "revolução redentora", o segundo embora tivesse apoiado a derrubada de João Goulart - mostrava-se receoso perante a possibilidade de um golpe que poderia se instalar naquele momento, 0 que se tornou realidade.

Finalizamos, assim, a seleção do arquivo de nossa pesquisa, recortando apenas as edições de ambos os jornais que deram conta de cobrir os primeiros momentos do movimento político de abril de 1964, a saber:

- Edições de 2 de abril: cobertura da deposição do presidente João Goulart e posse do presidente interino Raniere Mazzilli;

- Edição de 3 de abril: cobertura da legitimação do movimento político pelo Congresso Nacional;

- Edição de 10 de abril: cobertura da instauração do primeiro Ato Institucional.

Por sua vez, a quarta etapa foi presidida pela definição do(s) gênero(s) de discurso. Escolhemos a primeira página jornalística, já que ela suscita questões teóricas que merecem esclarecimentos, bem como não há estudos suficientes na área de concentração sobre esse hipergênero.

A quinta e última etapa de composição do corpus de nossa pesquisa consistiu no recorte da superfície discursiva com base nos gêneros constitutivos da primeira página dos jornais em estudo, em que os enunciados foram transcritos jornal por jornal, edição por edição, gênero por gênero, coluna por coluna, tal como apresentados na subseção seguinte deste trabalho. 


\subsection{Transcrição dos dados}

3.3.1 Transcrição das primeiras páginas de 2 de abril de 1964

3.3.1.1 Correio da Manhã, 02.04.1964



Figura 5 - Primeira página do Correio da Manhã, edição de 02.04.1964. 
Quadro 2 - Transcrição da primeira página do Correio da Manhã de 02.04.1964

\begin{tabular}{|c|c|}
\hline \multicolumn{2}{|r|}{ Texto 1} \\
\hline $\begin{array}{c}\text { Gênero de } \\
\text { discurso }\end{array}$ & Manchete \\
\hline $\begin{array}{l}\text { Corpo do } \\
\text { texto }\end{array}$ & MAZZILLI É O NÔVO PRESIDENTE \\
\hline \multicolumn{2}{|r|}{ Texto 2} \\
\hline $\begin{array}{c}\text { Gênero de } \\
\text { discurso }\end{array}$ & Nota comentário relatado (contígua à manchete) \\
\hline $\begin{array}{l}\text { Corpo do } \\
\text { texto }\end{array}$ & 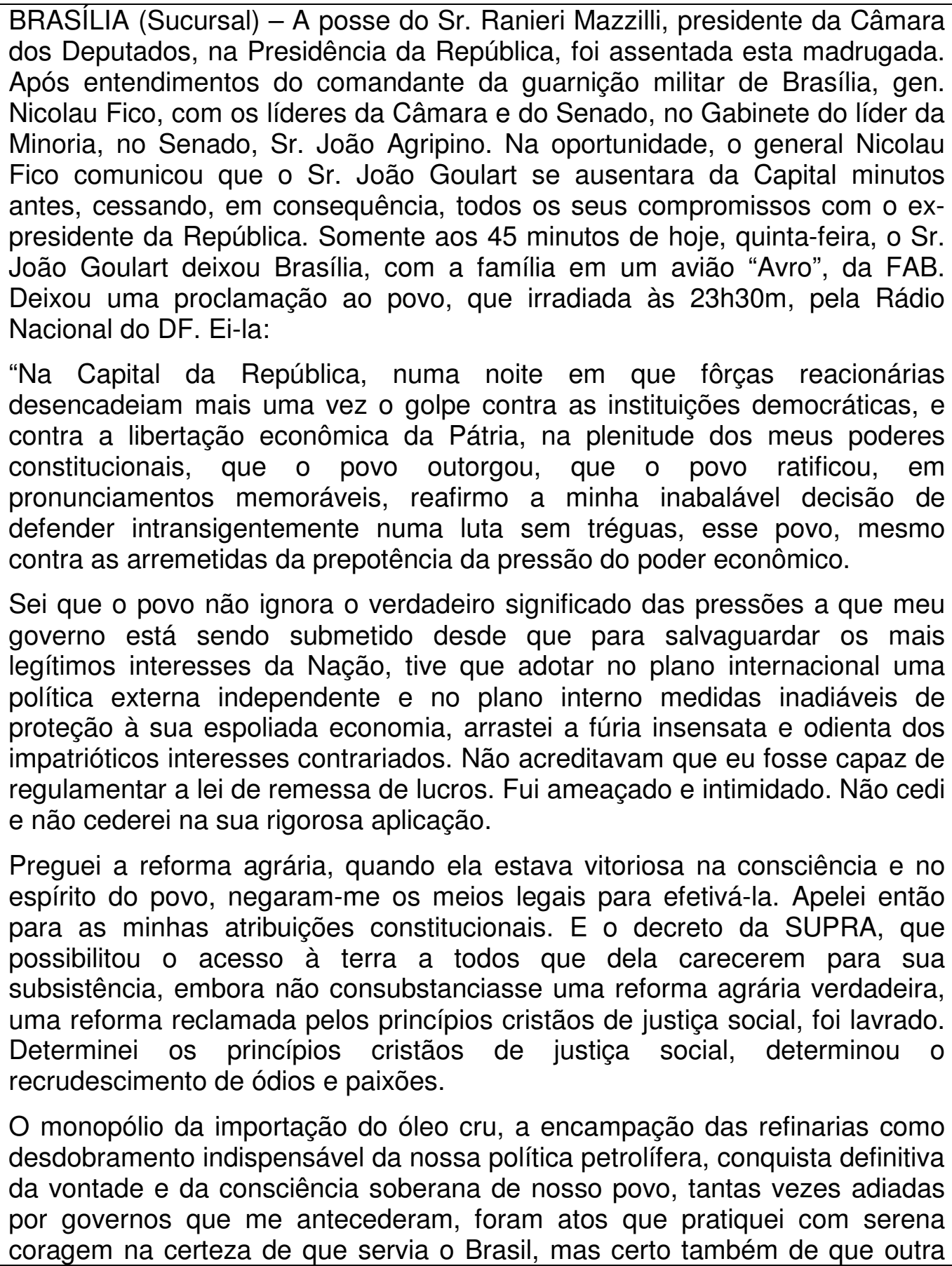 \\
\hline
\end{tabular}




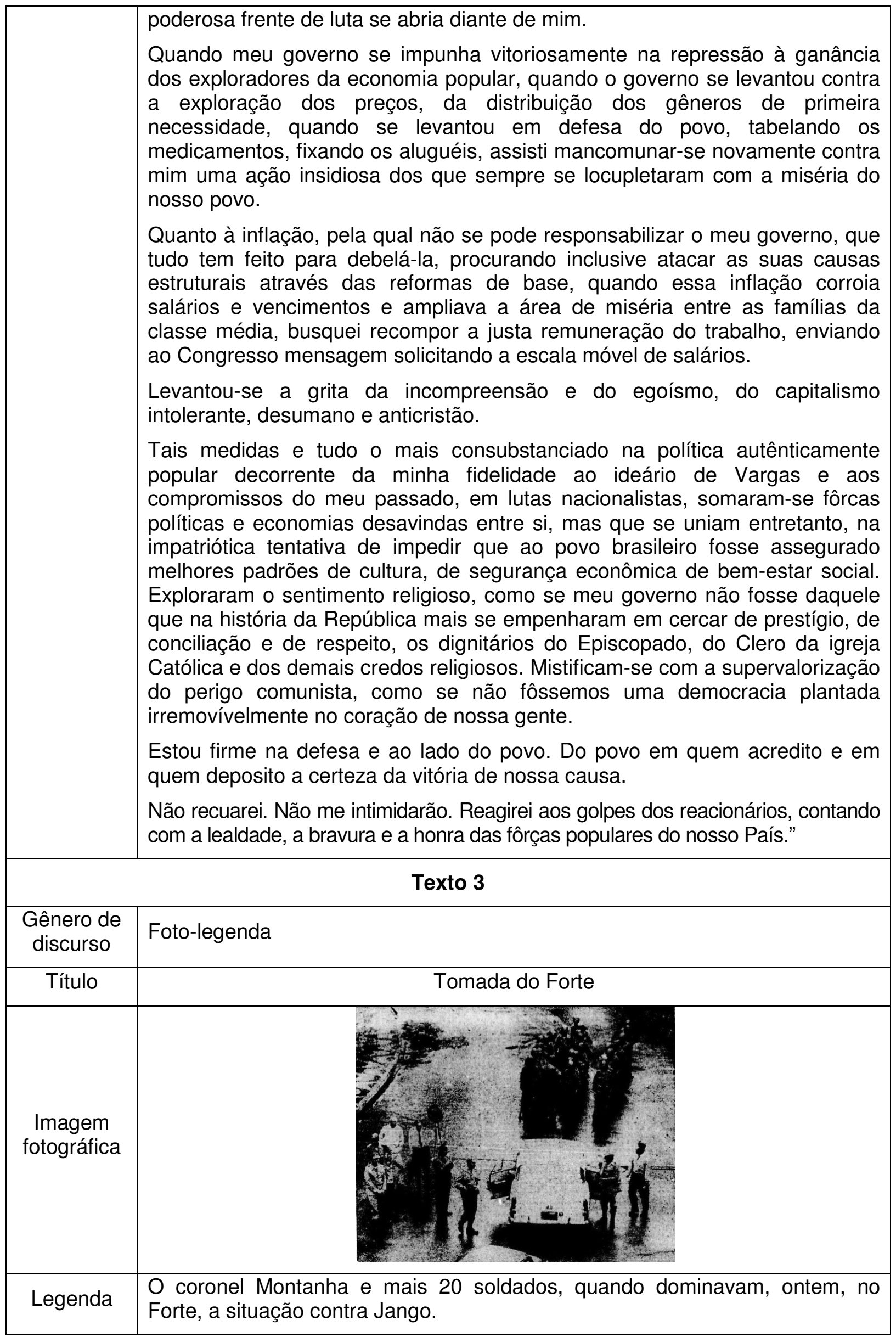




\begin{tabular}{|c|c|}
\hline \multicolumn{2}{|r|}{ Texto 4} \\
\hline $\begin{array}{l}\text { Gênero de } \\
\text { discurso }\end{array}$ & Notícia \\
\hline Título & Congresso declara vaga Presidência \\
\hline $\begin{array}{l}\text { Corpo do } \\
\text { texto }\end{array}$ & $\begin{array}{l}\text { BRASÍLIA (Sucursal) - ÁS 3h25m de hoje o sr. Moura Andrade, presidente do } \\
\text { Congresso Nacional, declarou vago o cargo de presidente da República, em } \\
\text { sessão extraordinária que durou cinco minutos, com a presença de } 150 \\
\text { senadores e deputados e do general André Fernandes. O líder do PTB, Doutel } \\
\text { de Andrade, disse que sua bancada não aceitava a declaração de vacância } \\
\text { porque, conforme ofício do chefe da Casa Civil, o sr. João Goulart estava a } \\
\text { caminho do Rio Grande do Sul, de onde exerceria a presidência. O sr. Moura } \\
\text { Andrade não considerou aquela comunicação e empossou no cargo o sr. } \\
\text { Ranieri Mazzili. O ato de posse se verificou no Palácio do Planalto, o sr. } \\
\text { Mazzilli proferiu breves palavras, ressaltando o seu orgulho pela assunção do } \\
\text { cargo. }\end{array}$ \\
\hline \multicolumn{2}{|r|}{ Texto 5} \\
\hline $\begin{array}{l}\text { Gênero de } \\
\text { discurso }\end{array}$ & Notícia \\
\hline Título & Aumento de militares vai a Orçamento \\
\hline $\begin{array}{l}\text { Corpo do } \\
\text { texto }\end{array}$ & $\begin{array}{l}\text { BRASÍLIA (Sucursal) - Na Comissão de Segurança Nacional da Câmara } \\
\text { Federal foi aprovado, ontem, o aumento dos militares, proposto ao Congresso } \\
\text { pelo govêrno em meados de março. A aprovação foi feita de acordo com } \\
\text { alterações à matéira pelo sr. Costa Cavalcânti (UDN - PE), que se manifestou } \\
\text { conta a paridade de vencimentos entre militares e civis, sugerida por emenda } \\
\text { ao sr. Paulo Mincaroni (PTB-RS). A proposição vai agora à comissão de } \\
\text { Orçamento. }\end{array}$ \\
\hline \multicolumn{2}{|r|}{ Texto 6} \\
\hline $\begin{array}{l}\text { Gênero de } \\
\text { discurso }\end{array}$ & Notícia \\
\hline Título & Arraes sitiado em Palácio \\
\hline $\begin{array}{l}\text { Corpo do } \\
\text { texto }\end{array}$ & $\begin{array}{l}\text { RECIFE- (Do correspondente) - A situação nesta Capital está dominada pelo } \\
\text { IV Exército, sob o comando do general Justino Alves Bastos que, conta com a } \\
\text { solidariedade do almirante Dias Fernandes, comandante do III Distrito Naval. } \\
\text { O comando naval deslocou tropas de fuzileiros para ocupar os portos de Natal } \\
\text { e Recife. Às } 14 \text { horas de ontem, o ex-governador Miguel Arraes conferenciou } \\
\text { com o almirante Fernandes mas não aceitou o têrmo de renúncia ao govêrno, } \\
\text { sendo sitiado em Palácio por tropas do 140 Regimento de Infantaria, sem } \\
\text { qualquer comunicação com o exterior. Por outro lado, na Assembléia } \\
\text { Legislativa foi aprovado o "impeachment" do governador do Estado, sendo } \\
\text { empossado no cargo o vice-governador Paulo Guerra. A Polícia Militar do } \\
\text { Estado está solidária com o nôvo governador. As classes produtoras lançaram } \\
\text { manifesto pelo reinício das atividades normais amanhã em virtude do } \\
\text { fechamento do Comando Geral dos Trabalhadores na Guanabara. }\end{array}$ \\
\hline
\end{tabular}




\begin{tabular}{|c|c|}
\hline \multicolumn{2}{|r|}{ Texto 7} \\
\hline $\begin{array}{l}\text { Gênero de } \\
\text { discurso }\end{array}$ & Nota comentário relatado \\
\hline Título & ARTUR COSTA É O NÔVO CHEFE DO EXÉRCITO \\
\hline Olho & $\begin{array}{l}\text { O general-de-Exército Artur da Costa e Silva foi empossado, na madrugada } \\
\text { de hoje, nas funções de comandante-em-chefe do Exército nacional }\end{array}$ \\
\hline $\begin{array}{l}\text { Corpo do } \\
\text { texto }\end{array}$ & 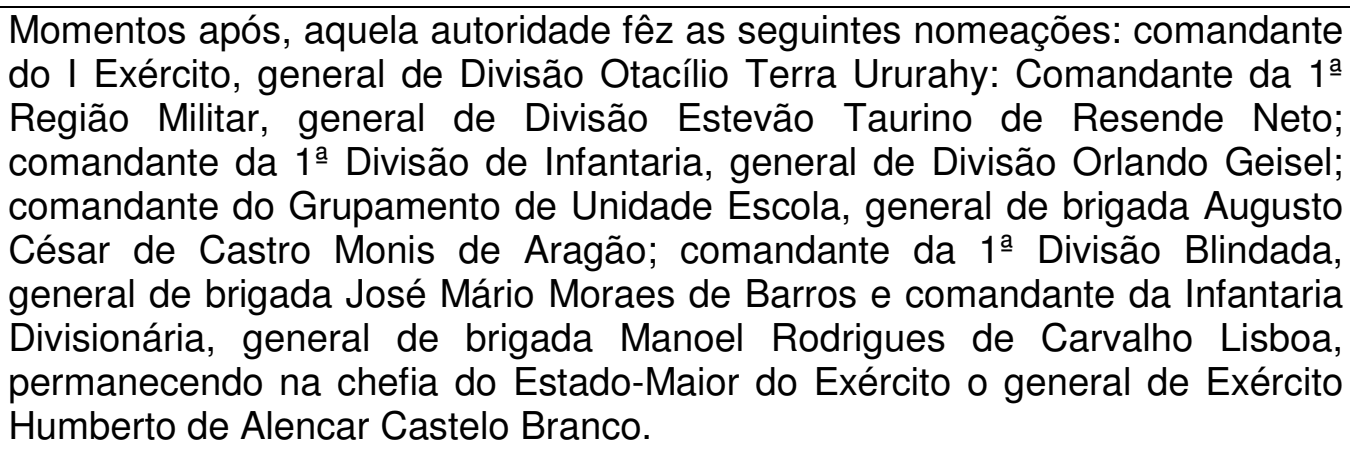 \\
\hline Subtítulo & Nota oficial \\
\hline $\begin{array}{l}\text { Corpo do } \\
\text { subtítulo da } \\
\text { nota } \\
\text { comentário } \\
\text { relatado }\end{array}$ & $\begin{array}{l}\text { O Estado-Maior do Exército distribuiu [na madrugada?] de hoje a seguinte } \\
\text { nota oficial: "Face a presente situação militar de fato, criada em virtude dos } \\
\text { últimos acontecimentos ocorridos no País, e na qualidade de membro mais } \\
\text { antigo do alto comando, o excelentíssimo sr. General de Exército Artur da Costa } \\
\text { e Silva assumiu a uma hora do dia } 2 \text { de abril, em cerimônia realizada no Palácio } \\
\text { da Guerra, na presença dos oficiais generais que se encontram no Estado da } \\
\text { Guanabara, as funções de comandante-em-chefe do Exército Nacional. De } \\
\text { imediato, sua excelência tomou uma série de providências, notadamente a } \\
\text { nomeação de diversos postos de comando, tendo e vista restabelecer a coesão } \\
\text { e a eficiência operativa das grandes unidades do Exército, com o objetivo } \\
\text { primordial de assegurar a ordem no País e sobretudo de eliminar a subversão } \\
\text { dirigida no Rio Grande do Sul, por Leonel Brizola." }\end{array}$ \\
\hline \multicolumn{2}{|r|}{ Texto 8} \\
\hline $\begin{array}{l}\text { Gênero de } \\
\text { discurso }\end{array}$ & Notícia \\
\hline Título & Tropas do Paraná vão para o RS \\
\hline $\begin{array}{l}\text { Corpo do } \\
\text { texto }\end{array}$ & $\begin{array}{l}\text { SÃO PAULO (Sucursal) - O governador Ademar de Barros manteve contato } \\
\text { [telefônico às últimas horas de] ontem, com o governador Nei Braga, } \\
\text { inteirando-se da situação naquele Estado. Segundo o chefe do Executivo } \\
\text { paranaense, a situação no se Estado é de tranquilidade "com o dispositivo da } \\
\text { legalidade funcionando ativamente". No Palácio do govêrno do Paraná } \\
\text { encontravam-se na ocasião o marechal Nélson de Mello e o general Cordeiro } \\
\text { de Farias, líderes intelectuais da sublevação pela legalidade. Informou o } \\
\text { general Cordeiro de Farias ao governador paulista que as tropas paranaenses } \\
\text { estão s deslocando para o Rio Grande do Sul, através de Santa Catarina, } \\
\text { onde, ali a situação é normal e sob o domínio das tropas legalistas que } \\
\text { esperam deslocar contingentes para atingir as fronteiras gaúchas, ainda } \\
\text { dominadas pelas fôrças do III Exército. }\end{array}$ \\
\hline
\end{tabular}




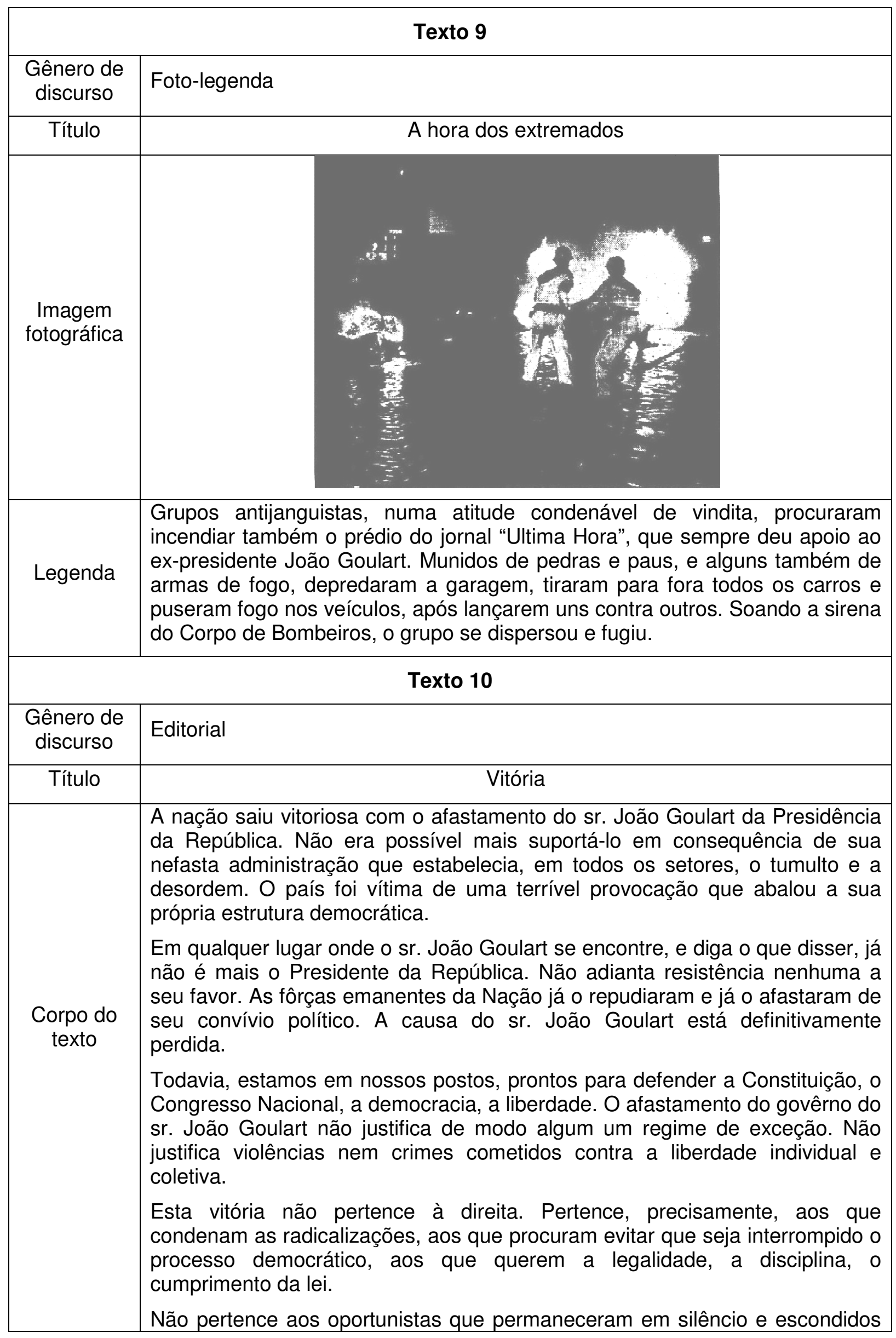




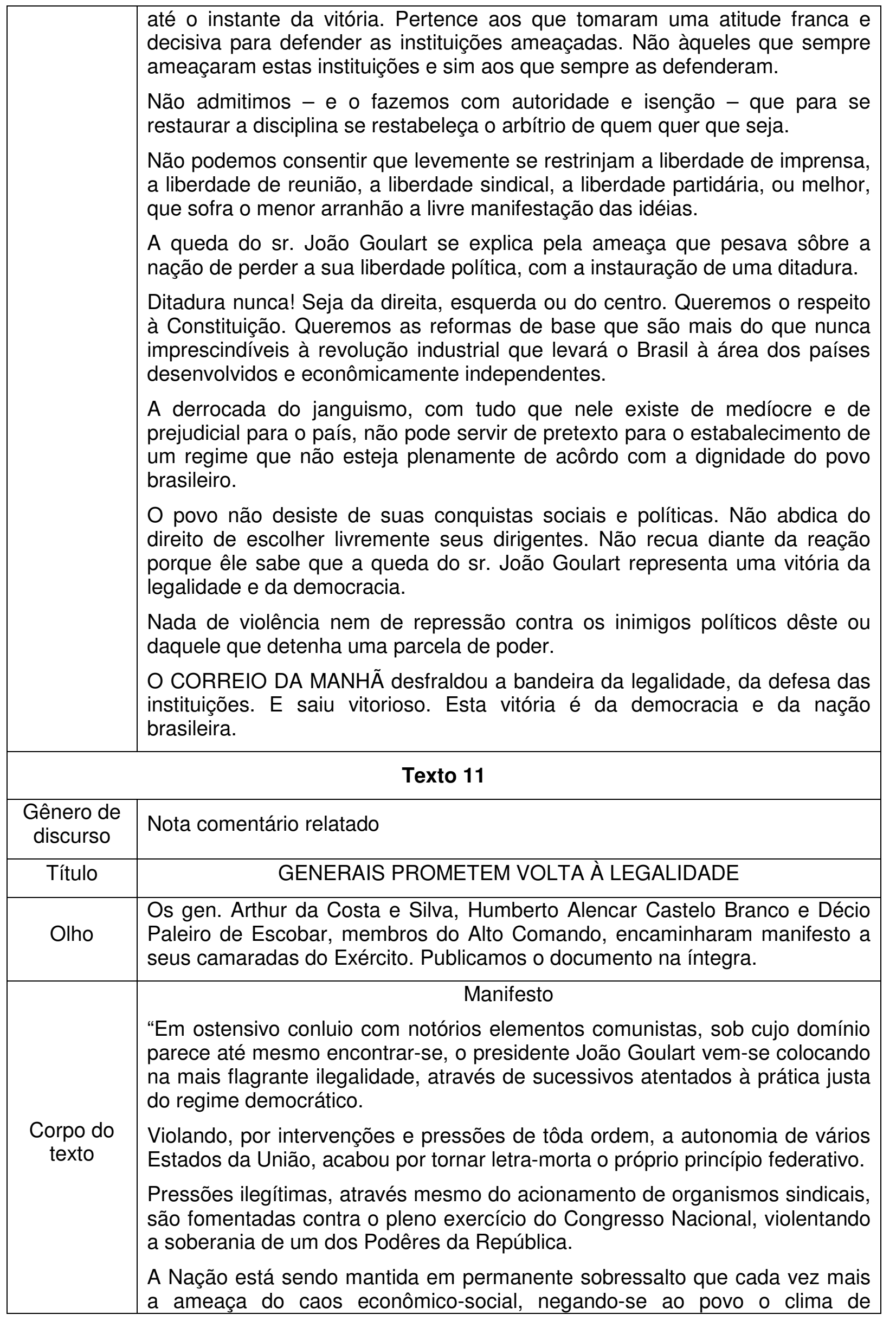


tranquilidade e de ordem indispensável ao trabalho honesto e fecundo, ao desenvolvimento da economia nacional e ao aprimoramento da justiça social.

Nessa obra de distribuição de nossas mais caras tradições democráticas e cristãs, as liberdades públicas encontram-se dia a dia ameaçadas por medidas discriminatórias que impedem a livre manifestação do pensamento.

\section{Atentado}

Para golpear a fundo o regime democrático, atentar-se sistematicamente contra as instituições militares que a Constituição Federal requer sejam "organizadas com base na hierarquia e na disciplina, sob a autoridade suprema do presidente da República e dentro dos limites da lei. É, pois, na sua estrutura e na sua essência mesmo que as Fôrças Armadas estão sendo destruídas, quando se subverte a hierarquia e é o próprio presidente da República quem incita à indisciplina e oferece plena cobertura a motins desencadeados, à vista do povo todo, sob a orientação de comunistas conhecidos. Dessa forma, esvai-se a autoridade de um presidente da República que a si mesmo não se respeita, em atitudes de franca demagogia e de menosprêso total aos padrões fundamentais das próprias fôrcas, postas, em nome da Segurança Nacional. Sob a sua alta direção. E, tanto mais quanto essa autoridade busca, a todo momento, exerce-se com amplo desrespeito à lei suprema do país, feridas em sues princípios essenciais.

Destinam-se as Fôrças Armadas, como estatui a Constituição, a defender a Pátria e a garantir os poderes constitucionais, a lei e a ordem. E é justamente para que possam elas integralmente cumprir tal destinação constitucional, que se impõe, sem tardanças, dizer um "Basta!" terminante a essas manobras desagregadoras e subversivas.

O exército Brasileiro, fiel a todo o seu passado de devotamento à Pátria, não pode mais assistir impassível - muito menos prestar qualquer colaboração - à trágica derrocada das próprias instituições militares.

\section{Conclamação}

Conscientes das responsabilidades que nos cabem como Chefes, conclamamos a todos os camaradas do Exército Brasileiro, sem distinção de postos ou de graduações, a cerrar fileiras em nome da Segurança Nacional para salvaguarda da estrutura das nossas Fôrças Armadas irmãs, Marinha e Aeronáutica, bem como as Fôrças Auxiliares Estaduais, reservas do Exército, não nos faltarão em seu apoio.

Teremos com tal atitude efetivamente evitado a luta fratricida que, na verdade, vem sendo preparada, irresponsável e criminosamente, pelo presidente da República e seus aliados comunistas.

E, coesos e unidos, restauraremos a legalidade, como é do nosso dever, assegurando a plena vigência do regime democrático.

Camaradas do Exército, unamo-nos em defesa do Brasil.

Esta é a hora decisiva". 


\begin{tabular}{|c|c|}
\hline \multicolumn{2}{|r|}{ Texto 12} \\
\hline $\begin{array}{l}\text { Gênero de } \\
\text { discurso }\end{array}$ & Notícia \\
\hline Título & Belonaves dirigem-se a Santos \\
\hline $\begin{array}{l}\text { Corpo do } \\
\text { texto }\end{array}$ & $\begin{array}{l}\text { SÃO PAULO (Sucursal) - Notícias não confirmadas que circularam na noite } \\
\text { de ontem nesta capital, informam que o navio "Tamandaré" e o destróier } \\
\text { "Pará" deslocaram-se da Bahia de Guanabara com destino ao pôrto de } \\
\text { Santos. A belonave "Tamandaré" vem comandada pelo almirante Sílvio Heck } \\
\text { e o "Pará" pelo almirante José Uzeda. } \\
\text { As naves saíram da barra do Rio de Janeiro, na noite de ontem e têm como } \\
\text { objetivo reforçar o dispositivo naval legalista, montado na baixada santista. }\end{array}$ \\
\hline \multicolumn{2}{|r|}{ Texto 13} \\
\hline $\begin{array}{l}\text { Gênero de } \\
\text { discurso }\end{array}$ & Notícia \\
\hline Título & Kruel diz que CGT terminou \\
\hline $\begin{array}{l}\text { Corpo do } \\
\text { texto }\end{array}$ & $\begin{array}{l}\text { O sr. Osvaldo Pacheco presidente do PUA e membro do CGT, foi prêso, em } \\
\text { São Paulo, pelo governador Ademar de Barros. O general Amauri Kruel } \\
\text { declarou que não existe mais o CGT, e que todos os seus membros serão } \\
\text { presos e processados pela Lei de Segurança. O sargente Garcia, embora } \\
\text { deputado, está prêso e será processado. Esta medida atingirá outros } \\
\text { deputados, que serão também processados pela Lei de Segurança. } \\
\text { Foi também ordenada a prisão do almirante Aragão, que será julgado "por } \\
\text { muitos crimes cometidos". }\end{array}$ \\
\hline \multicolumn{2}{|r|}{ Texto 14} \\
\hline $\begin{array}{l}\text { Gênero de } \\
\text { discurso }\end{array}$ & Notícia \\
\hline Título & Tiroteio na Cinelândia fere quatro \\
\hline $\begin{array}{l}\text { Corpo do } \\
\text { texto }\end{array}$ & $\begin{array}{l}\text { Um grupo de pessoas, entre populares e estudantes, apedrejou ontem o } \\
\text { Clube Militar aos gritos de que "ali estavam reunidos os gorilas", "os anti-povo" } \\
\text { e "Jango". Os atacantes com pedras de considerável tamanho, conseguiram } \\
\text { quebrar alguns vidros do Clube, mas imediatamente foram repelidos a bala, o } \\
\text { que ocasionou ferimentos graves em quatro pessoas. } \\
\text { O tiroteio que se estendeu até a Cinelândia ocasionou correrias no centro da } \\
\text { cidade, inclusive ferimentos leves em várias pessoas que foram jogadas ao } \\
\text { chão. Os civis baleados nos incidentes no Clube Militar são os seguintes: } \\
\text { Expedito Antônio de Freitas, } 33 \text { anos, advogado, ferido a bala no crânio; } \\
\text { Joaquim Amaro da Silva, } 20 \text { anos, estudante, ferido a bala na região lombar; } \\
\text { Edmar Correia, } 32 \text { anos, casado, acadêmico de Direito, ferimento penetrante } \\
\text { na região clavicular direita e Labide Carneiro Abitude, } 50 \text { anos presumíveis, } \\
\text { ferimento penetrante no hemitórax direito. Os feridos foram internados no } \\
\text { Hospital Sousa Aguiar, onde se encontram em estado grave. }\end{array}$ \\
\hline
\end{tabular}


3.3.1.2 O Globo, 02.04.1964

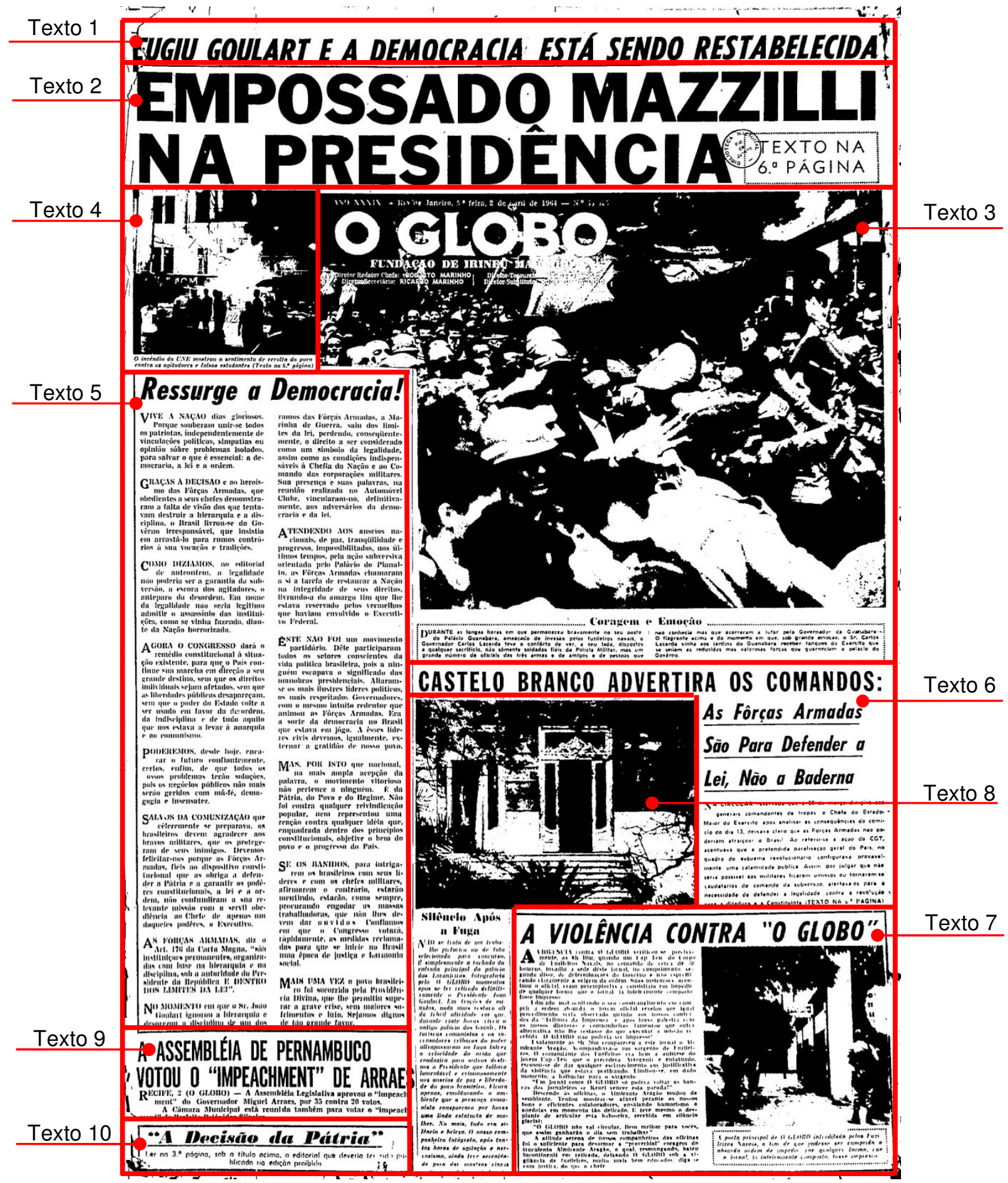

Figura 6 - Primeira página d'O Globo, edição de 02.04.1964. 
Quadro 3 - Transcrição da primeira página d'O Globo de 02.04.1964

\begin{tabular}{|c|c|}
\hline \multicolumn{2}{|r|}{ Texto 1} \\
\hline $\begin{array}{l}\text { Gênero de } \\
\text { discurso }\end{array}$ & Chapéu da página \\
\hline $\begin{array}{l}\text { Corpo do } \\
\text { texto }\end{array}$ & FUGIU GOULART E A DEMOCRACIA ESTÁ SENDO RESTABELECIDA \\
\hline \multicolumn{2}{|r|}{ Texto 2} \\
\hline $\begin{array}{l}\text { Gênero de } \\
\text { discurso }\end{array}$ & Manchete \\
\hline $\begin{array}{l}\text { Corpo do } \\
\text { texto }\end{array}$ & EMPOSSADO MAZZILLI NA PRESIDÊNCIA (texto na $6^{\text {a }}$ página) \\
\hline \multicolumn{2}{|r|}{ Texto 3} \\
\hline $\begin{array}{l}\text { Gênero de } \\
\text { discurso }\end{array}$ & Foto-manchete \\
\hline Título & Coragem e emoção \\
\hline \multicolumn{2}{|l|}{$\begin{array}{l}\text { Imagem } \\
\text { fotográfica }\end{array}$} \\
\hline Legenda & $\begin{array}{l}\text { Durante as longas horas em que permaneceu bravamente no seu posto do } \\
\text { Palácio Guanabara, ameaçado de invasão pelos fuzileiros navais, o } \\
\text { Governador Carlos Lacerda teve o confôrto de ver, a seu lado, dispostos a } \\
\text { qualquer sacrifício, não sômente soldados fièis da Polícia Militar, mas um } \\
\text { grande número de oficiais das três armas e de amigos e de pessoas que não } \\
\text { conhecia mas que acorreram a lutar pelo Governador da Guanabara. } \\
\text { flagrante acima é do momento em que, sob grande emoção, o Sr. Carlos } \\
\text { Lacerda vinha aos jardins da Guanabara receber tanques do Exército que se } \\
\text { uniam às reduzidas mas valorosas fôrças que guarneciam o palácio do } \\
\text { Govêrno. }\end{array}$ \\
\hline & \\
\hline
\end{tabular}




\begin{tabular}{|c|c|}
\hline \multicolumn{2}{|r|}{ Texto 4} \\
\hline $\begin{array}{l}\text { Gênero de } \\
\text { discurso }\end{array}$ & Foto-legenda \\
\hline Título & Sem título \\
\hline \multicolumn{2}{|l|}{$\begin{array}{l}\text { Imagem } \\
\text { fotográfica }\end{array}$} \\
\hline Legenda & $\begin{array}{l}\text { O incêndio da UNE mostrou o sentimento de revolta do povo contra os } \\
\text { agitadores e falsos estudantes (Texto na } 6^{a} \text { página) }\end{array}$ \\
\hline \multicolumn{2}{|r|}{ Texto 5} \\
\hline $\begin{array}{l}\text { Gênero de } \\
\text { discurso }\end{array}$ & Editorial \\
\hline Título & Ressurge a democracia! \\
\hline $\begin{array}{l}\text { Corpo do } \\
\text { texto }\end{array}$ & $\begin{array}{l}\text { VIVE A NAÇÃO dias gloriosos. Porque souberam unir-se todos os patriotas, } \\
\text { independentemente de vinculações políticas, simpatias ou opinião sôbre } \\
\text { problemas isolados, para salvar o que é essencial: a democracia, a lei e a } \\
\text { ordem. } \\
\text { GRAÇAS À DECISÃO e ao heroísmo das Fôrças Armadas, que obedientes a } \\
\text { seus chefes demonstraram a falta de visão dos que tentavam destruir a } \\
\text { hierarquia e a disciplina, o Brasil livrou-se do Govêrno irresponsável, que } \\
\text { insistia em arrastá-lo para rumos contrários à sua vocação e tradições. } \\
\text { COMO DIZíAMOS, no editorial de anteontem, a legalidade não poderia ser a } \\
\text { garantia da subversão, a escora dos agitadores, o anteparo da desordem. } \\
\text { Em nome da legalidade não seria legítimo admitir o assassinato das } \\
\text { instituições, como se vinha fazendo, diante da Nação horrorizada. } \\
\text { AGORA O CONGRESSO dará o remédio constitucional à situação existente, } \\
\text { para que o País continue sua marcha em direção a seu grande destino, sem } \\
\text { que os direitos individuais sejam afetados, sem que as liberdades públicas } \\
\text { desapareçam, sem que o poder do Estado volte a ser usado em favor da } \\
\text { desordem, da indisciplina e de tudo aquilo que nos estava a levar à anarquia } \\
\text { e ao comunismo. } \\
\text { PODEREMOS, desde hoje, encarar o futuro confiantemente, certos, enfim, } \\
\text { de que todos os nossos problemas terão soluções, pois os negócios públicos } \\
\text { não mais serão geridos com má-fé, demagogia e insensatez. }\end{array}$ \\
\hline
\end{tabular}




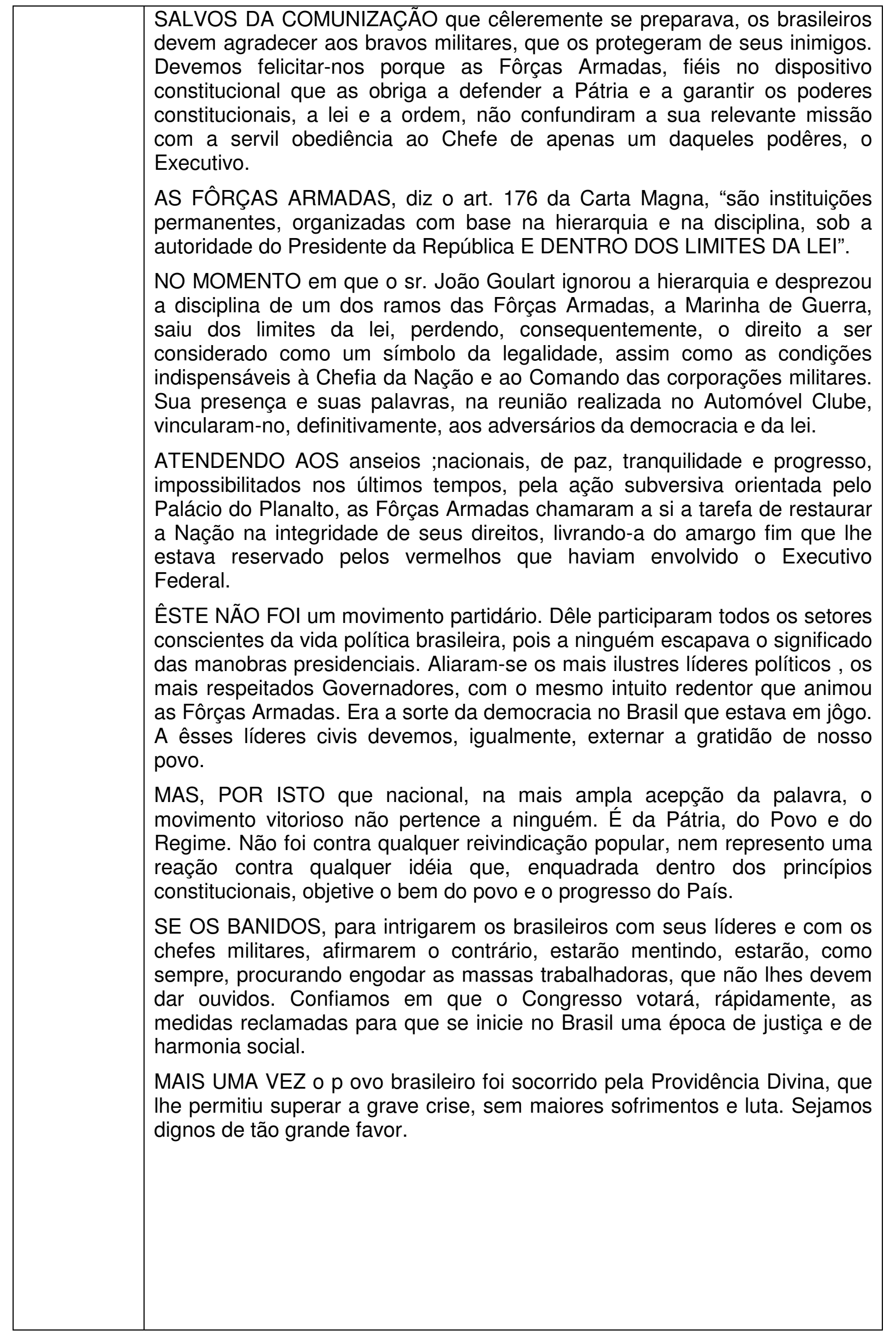




\begin{tabular}{|c|c|}
\hline \multicolumn{2}{|r|}{ Texto 6} \\
\hline $\begin{array}{l}\text { Gênero de } \\
\text { discurso }\end{array}$ & Notícia, com chamada de capa para aprofundamento da notícia \\
\hline Título & $\begin{array}{c}\text { CASTELO BRANCO ADVERTIRA OS COMANDOS: As Fôrças Armadas } \\
\text { São Para Defender a Lei, Não a Baderna }\end{array}$ \\
\hline $\begin{array}{l}\text { Corpo do } \\
\text { texto }\end{array}$ & $\begin{array}{l}\text { NA CIRCULAR reservada que a } 20 \text { de março dirigira aos generais } \\
\text { comandantes de tropas e Chefe do Estado-Maior do Exército após analisar } \\
\text { as consequências do comício do dia } 13 \text {, deixava claro que as Fôrças } \\
\text { Armadas não poderiam atraiçoar o Brasil. Ao referir-se a ação da CGT, } \\
\text { acentuava que a pretendida paralisação geral do País, no quadro do } \\
\text { esquema revolucionário configurava provávelmente uma calamidade pública. } \\
\text { Assim por julgar que não seria possível aos militares ficarem omissos ou } \\
\text { tornarem-se caudatários do comando da subversão, alertara os para a } \\
\text { necessidade de defender a legalidade contra a revolução para a ditadura e a } \\
\text { Constituinte (TEXTO NA 6ấ PÁGINA) }\end{array}$ \\
\hline \multicolumn{2}{|r|}{ Texto 7} \\
\hline $\begin{array}{l}\text { Gênero de } \\
\text { discurso }\end{array}$ & Notícia com foto \\
\hline Título & A VIOLÊNCIA CONTRA “O GLOBO” \\
\hline \multicolumn{2}{|l|}{$\begin{array}{l}\text { Imagem } \\
\text { fotográfica }\end{array}$} \\
\hline Legenda & $\begin{array}{l}\text { A porta principal de O GLOBO interditada pelos Fuzileiros Navais, a fim de } \\
\text { que pudesse ser cumprida a absurda ordem de impedir, por qualquer forma, } \\
\text { que o jornal, já inteiramente [???], fosse impresso. }\end{array}$ \\
\hline $\begin{array}{l}\text { Corpo do } \\
\text { texto }\end{array}$ & A violência contra O GLOBO [texto totalmente ilegível]. \\
\hline
\end{tabular}




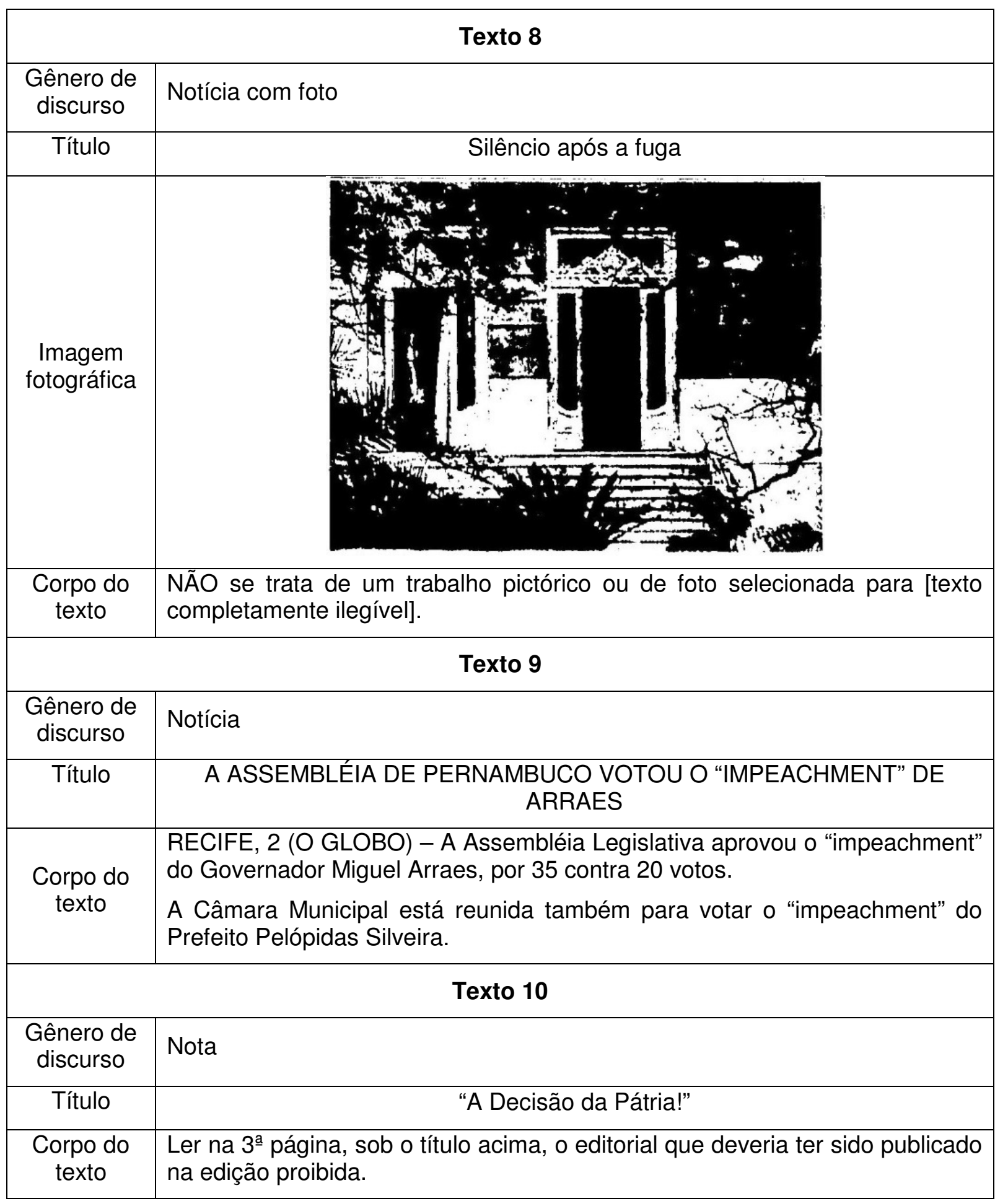




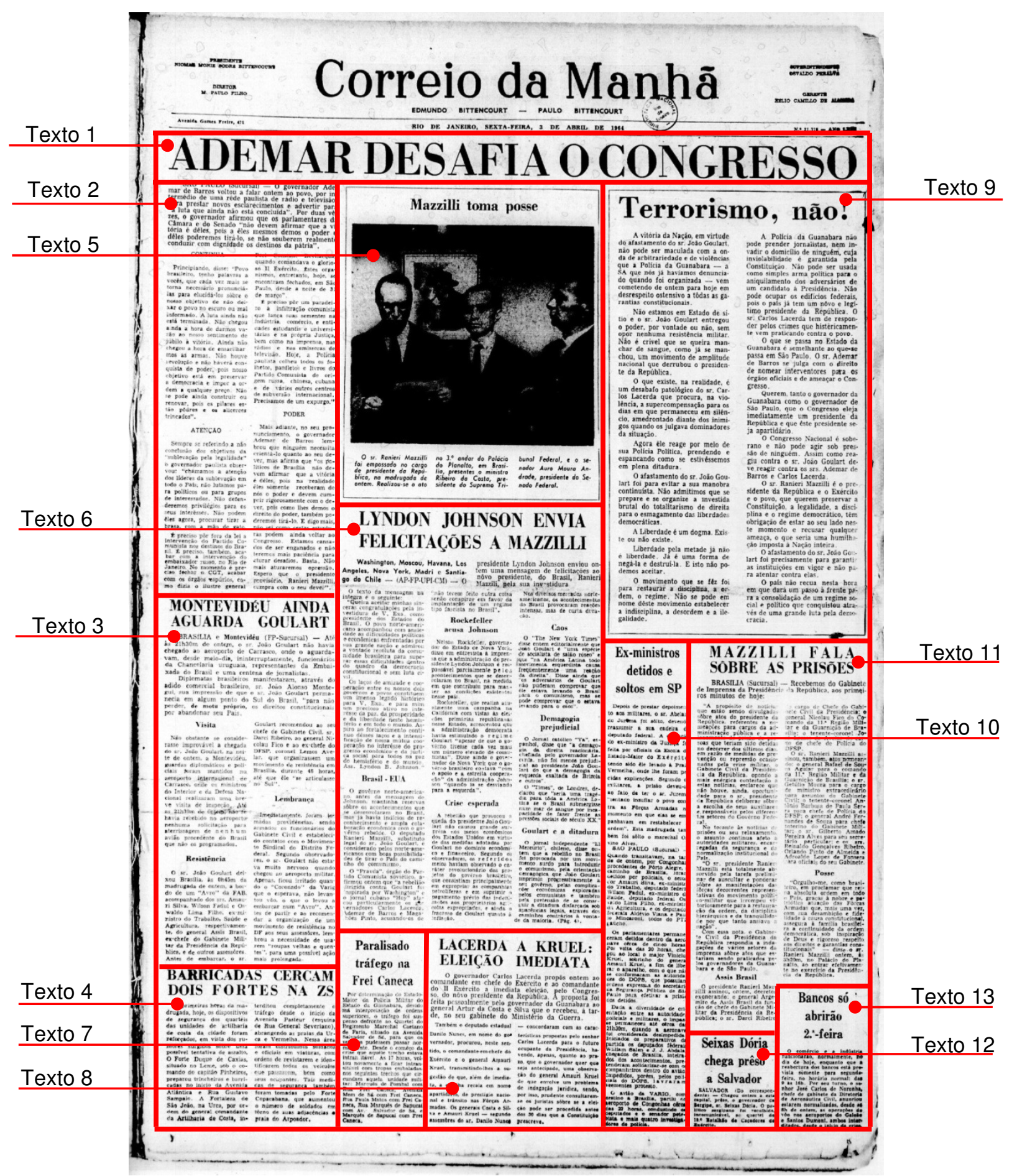

Figura 7 - Primeira página do Correio da Manhã, edição de 03.04.1964. 
Quadro 4 - Transcrição da primeira página do Correio da Manhã de 03.04.1964

\begin{tabular}{|c|c|}
\hline \multicolumn{2}{|r|}{ Texto 1} \\
\hline $\begin{array}{l}\text { Gênero de } \\
\text { discurso }\end{array}$ & Manchete \\
\hline $\begin{array}{l}\text { Corpo do } \\
\text { texto }\end{array}$ & ADEMAR DESAFIA O CONGRESSO \\
\hline \multicolumn{2}{|r|}{ Texto 2} \\
\hline $\begin{array}{l}\text { Gênero de } \\
\text { discurso }\end{array}$ & Notícia contígua à manchete \\
\hline $\begin{array}{l}\text { Corpo do } \\
\text { texto }\end{array}$ & $\begin{array}{l}\text { SÃO PAULO (Sucursal) - O governador Ademar de Barros voltou a falar } \\
\text { ontem ao povo, por intermédio de uma rêde paulista de rádio e televisão, } \\
\text { para prestar novos esclarecimentos e advertir para "a luta que ainda não está } \\
\text { concluída". Por duas vêzes, o governador afirmou que os parlamentares da } \\
\text { Câmara e do Senado "não devem afirmar que a vitória é dêles, pois a êles } \\
\text { mesmos demos o poder e dêles poderemos tirá-lo, se não souberem } \\
\text { realmente conduzir com dignidade os destinos da pátria". }\end{array}$ \\
\hline Subtítulo & CONTINUA \\
\hline $\begin{array}{l}\text { Corpo do } \\
\text { texto }\end{array}$ & $\begin{array}{l}\text { Principiando, disse: "Povo brasileiro, tenho palavras a vocês, que cada vez } \\
\text { mais se torna necessário pronunciá-las para elucidá-los sôbre o nosso objetivo } \\
\text { de não deixar o povo no escuro ou mal informado. A luta ainda não está } \\
\text { terminada. Não chegou ainda a hora de darmos vazão ao nosso sentimento de } \\
\text { júbilo à vitória. Ainda não chegou a hora de ensarilharmos as armas. Não } \\
\text { houve revolução e não haverá conquista de poder, pois nosso objetivo está em } \\
\text { preservar a democracia e impor a ordem a qualquer preço. Não se pode ainda } \\
\text { construir ou renovar, pois os pilares estão pôdres e os alicerces trincados". }\end{array}$ \\
\hline Subtítulo & $\begin{array}{ll}\text { ATENÇÃO } \\
\end{array}$ \\
\hline $\begin{array}{l}\text { Corpo do } \\
\text { texto }\end{array}$ & $\begin{array}{l}\text { Sempre se referindo a não conclusão dos objetivos da "sublevação pela } \\
\text { legalidade" o governador paulista observou: "chamamos a atenção dos líderes } \\
\text { da sublevação em todo o País, não lutamos para políticos ou para grupos de } \\
\text { interesses. Não podem êles agora, procurar tirar a brasa, com a mão de gato. } \\
\text { É preciso pôr fora da lei a intervenção do Partido Comunista nos destinos do } \\
\text { Brasil. É preciso, também, acabar com a intervenção do embaixador russo, } \\
\text { no Rio de Janeiro. No momento é preciso fechar o CGT, acabar com os } \\
\text { órgãos espúrios, como dizia o ilustre general Peri Constant Bevilacqua, } \\
\text { quando comandava o glorioso II Exército. Êstes organismos, entretanto, hoje, } \\
\text { se encontram fechados, em São Paulo, desde a noite de } 31 \text { de março". } \\
\text { É preciso pôr um paradeiro à infiltração comunista que lança suas sementes } \\
\text { na indústria, comércio, e entidades estudantis e universitárias e na própria } \\
\text { Justiça, bem como na imprensa, nas rádios e nas emissoras de televisão. } \\
\text { Hoje, a Polícia paulista colheu todos os folhetos, panfletos e livros do Partido } \\
\text { Comunista de origem russa, chinesa, cubana e de vários outros centros de } \\
\text { subversão internacional. Precisamos de um expurgo." }\end{array}$ \\
\hline Subtítulo & PODER \\
\hline Corpo do & $\begin{array}{l}\text { Mais adiante, no seu pronunciamento, o governador Ademar de Barros } \\
\text { lembrou que ninguém necessita orientá-lo quanto ao seu dever, mas afirma }\end{array}$ \\
\hline
\end{tabular}




\begin{tabular}{|c|c|}
\hline texto & $\begin{array}{l}\text { que "os políticos de Brasília não devem afirmar que a vitória é dêles, pois na } \\
\text { realidade êles somente receberam de nós o poder e devem cumprir } \\
\text { rigorosamente com o dever, pois como lhes demos o direito do poder, também } \\
\text { poderemos tirá-lo. E digo mais, não sei como certas estruturas podem ainda } \\
\text { voltar ao Congresso. Estamos cansados de ser enganados e não teremos } \\
\text { mais paciência para aturar desafios. Basta. Não mais aturaremos opressão. } \\
\text { Espero que o presidente provisório, Ranieri Mazzilli, cumpra com o seu dever". }\end{array}$ \\
\hline \multicolumn{2}{|r|}{ Texto 3} \\
\hline $\begin{array}{c}\text { Gênero de } \\
\text { discurso }\end{array}$ & Notícia \\
\hline Título & MONTEVIDÉU AINDA AGUARDA GOULART \\
\hline $\begin{array}{l}\text { Corpo do } \\
\text { texto }\end{array}$ & $\begin{array}{l}\text { BRASÍLIA e Montevidéu (FP- Sucursal) - Até às } 21 \mathrm{~h} 30 \mathrm{~m} \text { de ontem, o sr. } \\
\text { João Goulart não havia chegado ao aeroporto de Carrasco, onde o } \\
\text { aguardavam, desde meio-dia, ininterruptamente, funcionários da Chancelaria } \\
\text { uruguaia, representantes da Embaixada do Brasil e uma centena de } \\
\text { jornalistas. } \\
\text { Diplomatas brasileiros manifestaram através do adido comercial brasileiro, sr. } \\
\text { João Alonso Montegui, sua impressão de que o sr. João Goulart permanecia } \\
\text { em algum ponto do Sul do Brasil, "para não perder, de motu próprio, os } \\
\text { direitos constitucionais por abandonar seu País. }\end{array}$ \\
\hline Subtítulo & Visita \\
\hline $\begin{array}{l}\text { Corpo do } \\
\text { texto }\end{array}$ & $\begin{array}{l}\text { Não obstante se considerasse improvável a chegada do sr. João Goulart, na } \\
\text { noite de ontem, a Montevidéu, guardas diplomáticos e policiais foram } \\
\text { mantidos no aeroporto internacional de Carrasco, onde os ministros do } \\
\text { Interior da Defesa Nacional realizaram uma breve visita de inspeção. Até as } \\
21 \text { h30m de ontem não se havia recebido no aeroporto nenhuma solicitação } \\
\text { para aterrissagem de nenhum avião procedente do Brasil que não os } \\
\text { programados. }\end{array}$ \\
\hline Subtítulo & Resistência \\
\hline $\begin{array}{l}\text { Corpo do } \\
\text { texto }\end{array}$ & $\begin{array}{l}\text { O sr. João Goulart deixou Brasília, às } 0 \text { h45m da madrugada de ontem a } \\
\text { bordo de um "Avro" da FAB, acompanhado dos srs. Amauri Silva, Wilson } \\
\text { Fadul e Oswaldo Lima Filho, ex-ministro do Trabalho, Saúde e Agricultura, } \\
\text { respectivamente, do general Assis Brasil, ex-chefe do Gabinete Militar da } \\
\text { Presidência da República, e de outros assesôres. Antes de embarcar, o sr. } \\
\text { Goulart recomendou ao seu chefe de Gabinete Civil, sr. Darci Ribeiro, ao } \\
\text { general Nicolau Fico e ao ex-chefe do DFSP, coronel Lemos Avelar, que } \\
\text { organizassem um movimento de resistência em Brasília, durante } 48 \text { horas, } \\
\text { até que êle "se articulasse no Sul". }\end{array}$ \\
\hline Subtítulo & Lembrança \\
\hline $\begin{array}{l}\text { Corpo do } \\
\text { texto }\end{array}$ & $\begin{array}{l}\text { Imediatamente, foram tomadas providências, sendo armados os funcionários } \\
\text { do Gabinete Civil e estabelecido contatos com o Movimento Sindical do } \\
\text { Distrito Federal, Segundo observadores, o sr. Goulart não estava muito } \\
\text { nervoso quando chegou ao aeroporto militar. Apenas, ficou irritado quando o } \\
\text { "Coronado" da Varig que o esperava não levantou vôo, o que o levou a } \\
\text { embarcar num "Avro". Antes de partir e ao recomendar a organização de um } \\
\text { movimento de resistência no DF aos seus assessôres, lembrou a } \\
\text { necessidade de usarem "roupas velhas e quentes", para uma possível ação } \\
\text { mais prolongada. }\end{array}$ \\
\hline
\end{tabular}




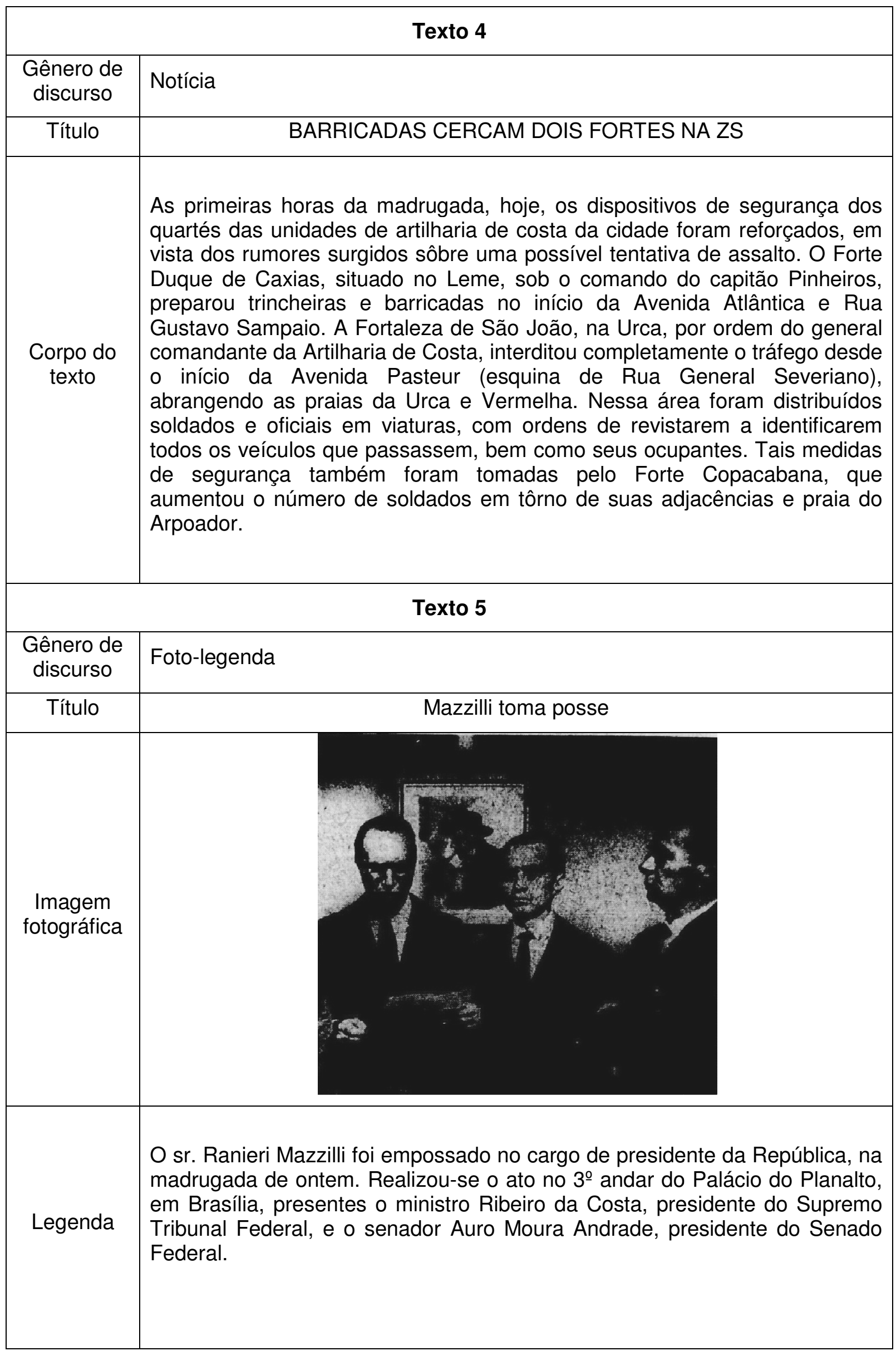




\begin{tabular}{|c|c|}
\hline \multicolumn{2}{|r|}{ Texto 6} \\
\hline $\begin{array}{l}\text { Gênero de } \\
\text { discurso }\end{array}$ & Notícia \\
\hline Título & LYNDON JOHNSON ENVIA FELICITAÇÕES A MAZZILLI \\
\hline $\begin{array}{l}\text { Corpo do } \\
\text { texto }\end{array}$ & $\begin{array}{l}\text { Washington, Moscou, Havana, Los Angeles, Nova York, Madri e Santiago do } \\
\text { Chile - (AP-FP-UPI-CM) - O presidente Lyndon Johnson enviou ontem uma } \\
\text { mensagem de felicitações ao nôvo presidente, do Brasil, Ranieri Mazzilli, } \\
\text { pela sua investidura } \\
\text { O texto da mensagem na íntegra é o seguinte: } \\
\text { "Queira aceitar minhas sinceras congratulações pela investidura de V. Exa. } \\
\text { como presidente dos Estados do Brasil. O povo norte-americano } \\
\text { acompanhou com ansiedade as dificuldades políticas e econômicas } \\
\text { enfrentadas por sua grande nação e admirou a vontade resoluta da } \\
\text { comunidade brasileira para superar essas dificuldades dentro do quadro da } \\
\text { democracia constitucional e sem luta civil. } \\
\text { Os laços de amizade e cooperação entre os nossos dois governos e povos } \\
\text { constituem um imenso legado histórico para V. Exa. e para mim um precioso } \\
\text { ativo no interêsse da paz, da prosperidade e da liberdade neste hemisfério e } \\
\text { em todo o mundo. Aspiro ao fortalecimento continuo dêsses laços e a } \\
\text { intensificação de nossa mútua cooperação no interêsse do progresso } \\
\text { econômico e da justiça social para todos na paz do hemisfério e do mundo. } \\
\text { Ass. Lyndon B. Johnson." }\end{array}$ \\
\hline Subtítulo & Brasil - EUA \\
\hline $\begin{array}{l}\text { Corpo do } \\
\text { texto }\end{array}$ & $\begin{array}{l}\text { O govêrno norte-americano, antes da mensagem de Johnson, mantinha } \\
\text { reservas sôbre os acontecimentos que se desenrolavam no Brasil, mas já } \\
\text { havia indícios de reconhecimento e ampla colaboração econômica com o } \\
\text { govêrno rebelde. O deputado Ranieri Mazzilli, substituto legal do sr. João } \\
\text { Goulart, é considerado pelos norte-americanos com boas possibilidades de } \\
\text { tirar o País do caminho do comunismo. } \\
\text { "Pravda", órgão do Partido Comunista soviético, afirmou ontem que "a } \\
\text { rebelião dirigida contra Goulart foi inspirada por Washington" e o jornal } \\
\text { cubano "Hoy" atacou particularmente os governadores Carlos Lacerda, } \\
\text { Ademar de Barros e Magalhães Pinto, acusando-os de "não terem feito outra } \\
\text { coisa senão conspirar em favor da implantação de um regime tipo fascista no } \\
\text { Brasil". }\end{array}$ \\
\hline Subtítulo & Rockefeller acusa Johnson \\
\hline $\begin{array}{l}\text { Corpo do } \\
\text { texto }\end{array}$ & $\begin{array}{l}\text { Nelson Rockefeller, governador do Estado de Nova York, disse em entrevista } \\
\text { à imprensa que a administração do presidente Lyndon Johnson é } \\
\text { responsável parcialmente pelos acontecimentos que se desenrolaram no } \\
\text { Brasil, na medida em que contribuiu para manter as condições existentes } \\
\text { nesse país. } \\
\text { Rockefeller, que realiza atualmente uma campanha na Califórnia com vistas } \\
\text { às eleições primárias republicanas nesse Estado, acrescentou que a } \\
\text { administração democrata havia estimulado o regime Goulart "apesar de que } \\
\text { o govêrno tivesse cada vez mais um número elevado de comunistas". Disse } \\
\text { ainda o governador de Nova York que o govêrno brasileiro contava "com o } \\
\text { apoio e a estreita cooperação" da administração Johnson "quanto ia se } \\
\text { desviando para a esquerda". }\end{array}$ \\
\hline
\end{tabular}




\begin{tabular}{|c|c|}
\hline Subtítulo & Crise esperada \\
\hline $\begin{array}{l}\text { Corpo do } \\
\text { texto }\end{array}$ & $\begin{array}{l}\text { A rebelião que provocou a queda do presidente João Goulart não causou } \\
\text { grande surprêsa nos meios econômicos dos Estados Unidos em virtude das } \\
\text { medidas adotadas por Goulart no domínio econômico e financeiro. Segundo } \\
\text { os observadores, os referidos meios haviam observado o caráter } \\
\text { revolucionário dos projetos do govêrno brasileiro, que consistiam } \\
\text { principalmente em expropriar as companhias petrolíferas e em suprimir o } \\
\text { pagamento prévio das indenizações aos proprietários agrícolas expropriados, } \\
\text { e ainda o fracasso de Goulart quanto à inflação. } \\
\text { Nos diversos mercados norte-americanos, os acontecimentos do Brasil } \\
\text { provocaram reações intensas, mas de curta duração. }\end{array}$ \\
\hline Subtítulo & Caos \\
\hline $\begin{array}{l}\text { Corpo do } \\
\text { texto }\end{array}$ & $\begin{array}{l}\text { O "The New York Times" disse ontem editorialmente que João Goulart é } \\
\text { "uma espécie socialista de salão róseo" e que "na América Latina todo } \\
\text { movimento esquerdista causa frequentemente uma reação da direita". Disse } \\
\text { ainda que "os adversários de Goulart não puderam comprovar que êle estava } \\
\text { levando o Brail para o comunismo, mas se pode comprovar que o estava } \\
\text { levando para o caos". }\end{array}$ \\
\hline Subtítulo & Demagogia prejudicial \\
\hline $\begin{array}{l}\text { Corpo do } \\
\text { texto }\end{array}$ & $\begin{array}{l}\text { O Jornal católico "Ya", espanhol, disse que a "demagogia da direita } \\
\text { reacionária chefiada pelo governador Lacerda, não foi menos prejudicial ao } \\
\text { presidente João Goulart do que a demagogia da esquerda exaltada de } \\
\text { Brizola e outros". } \\
\text { O "Times", de Londres, declarou que "seria uma tragédia para tôda a } \\
\text { América Latina se o Brasil submergisse num mar de sangue por } \\
\text { incapacidade de fazer frente as pressões sociais do século XX". }\end{array}$ \\
\hline Subtítulo & Goulart e a ditadura \\
\hline $\begin{array}{l}\text { Corpo do } \\
\text { texto }\end{array}$ & $\begin{array}{l}\text { O jornal independente "El Mercurio", chileno, disse ontem que a rebelião no } \\
\text { Brasil foi provocada por um movimento surdo para introduzir o comunismo, } \\
\text { pela orientação demagógica que João Goulart imprimiu progressivamente a } \\
\text { seu govêrno, pelas complicações econômicas exploradas pelos comunistas e } \\
\text { também pela pretensão de se conseguir a ditadura disfarçada sob } \\
\text { aparências legais, através dos caminhos contrários à vontade da maioria. } \\
\text { (Pág. 4). }\end{array}$ \\
\hline \multicolumn{2}{|r|}{ Texto 7} \\
\hline $\begin{array}{l}\text { Gênero de } \\
\text { discurso }\end{array}$ & Notícia \\
\hline Título & Paralisado tráfego na Frei Caneca \\
\hline $\begin{array}{l}\text { Corpo do } \\
\text { texto }\end{array}$ & $\begin{array}{l}\text { Por determinação do Estado-Maior da Polícia Militar do Estado da Guanabara, } \\
\text { devido má interpretação de ordens superiores, o tráfego foi suspenso defronte ao } \\
\text { Quartel do Regimento Marechal Caetano de Faria, situado na Avenida Salvador } \\
\text { de Sé, para que os veículos pudessem passar normalmente. Desde o comêço da } \\
\text { crise que aquêle trecho estava intransitável. Âs } 17 \text { horas, voltou novamente a ficar } \\
\text { intransitável com tropas embaladas, nos seguintes trechos que circundam aquela } \\
\text { unidade militar: Marquês de Pombal com Rua Frei Caneca, Avenida Mem de Sá } \\
\text { com Frei Caneca, Rua Paula Matos com Frei Caneca, Rua Marquês de Sapucaí } \\
\text { com Av. Salvador de Sé, e Marquês de Sapucaí com Frei Caneca. }\end{array}$ \\
\hline
\end{tabular}




\begin{tabular}{|c|c|}
\hline \multicolumn{2}{|r|}{ Texto 8} \\
\hline $\begin{array}{l}\text { Gênero de } \\
\text { discurso }\end{array}$ & Notícia \\
\hline Título & LACERDA A KRUEL: ELEIÇÃO IMEDIATA \\
\hline $\begin{array}{l}\text { Corpo do } \\
\text { texto }\end{array}$ & $\begin{array}{l}\text { O governador Carlos Lacerda propôs ontem ao comandante em chefe do } \\
\text { Exército e ao comandante do Il Exército a imediata eleição, pelo Congresso } \\
\text { do nôvo presidente da República. A proposta foi feita pessoalmente pelo } \\
\text { governador da Guanabara ao general Artur da Costa e Silva que o recebeu, } \\
\text { à tarde, no seu gabinete do Ministério da Guerra. } \\
\text { Também o deputado estadual Danilo Nunes, em nome do governador, } \\
\text { procurou, neste sentido, o comandante-em-chefe do Exército e o general } \\
\text { Amauri Kruel, transmitindo-lhes a sugestão de que, além de imediata, a } \\
\text { escolha recaia em nome apartidário, de prestígio nacional e trânsito nas } \\
\text { Fôrças Armadas. Os generais Costa e Silva e Amauri Kruel - segundo } \\
\text { assessôres do sr. Danilo Nunes - concordaram com as características } \\
\text { propostas pelo senhor Carlos Lacerda para o futuro ocupante da } \\
\text { Presidência, havendo, apenas, quanto ao prazo que o governador quer que } \\
\text { seja antecipado, uma observação do general Amauri Kruel de que envolve } \\
\text { um problema de indagação juŕdica, sendo, por isso, prudente consultarem- } \\
\text { se os juristas sôbre se a eleição pode ser procedida antes dos } 30 \text { dias que a } \\
\text { Constituição prescreve. }\end{array}$ \\
\hline \multicolumn{2}{|r|}{ Texto 9} \\
\hline $\begin{array}{c}\text { Gênero de } \\
\text { discurso }\end{array}$ & Editorial \\
\hline Título & TERRORISMO, NÃO! \\
\hline $\begin{array}{l}\text { Corpo do } \\
\text { texto }\end{array}$ & $\begin{array}{l}\text { A vitória da Nação, em virtude do afastamento do sr. João Goulart, não pode } \\
\text { ser maculada com a onda de arbitrariedade e de violências que a Polícia da } \\
\text { Guanabara - a AS que nós já havíamos denunciado quando foi organizada - } \\
\text { vem cometendo de ontem para hoje em desrespeito ostensivo a tôdas as } \\
\text { garantias constitucionais. } \\
\text { Não estamos em Estado de sítio e o sr. João Goulart entregou o poder, por } \\
\text { vontade ou não, sem opor nenhuma resistência militar. Não é crível que se } \\
\text { queira manchar de sangue, como já se manchou, um movimento de } \\
\text { amplitude nacional que derrubou o presidente da República. } \\
\text { O que existe, na realidade, é um desabafo patológico do sr. Carlos Lacerda } \\
\text { que procura, na violência, a supercompensação para os dias em que } \\
\text { permaneceu em silêncio, amedrontado diante dos inimigos quando os } \\
\text { julgava dominadores da situação. } \\
\text { Agora êle reage por meio de sua Polícia Política, prendendo e espancando } \\
\text { como se estivéssemos em plena ditadura. } \\
\text { O afastamento de sr. João Goulart foi para evitar a sua manobra continuísta. } \\
\text { Não admitimos que se prepare e se organize a investida brutal do } \\
\text { totalitarismo de direita para o esmagamento das liberdades democráticas. } \\
\text { A Liberdade é um dogma. Existe ou não existe. } \\
\text { Liberdade pela metade já não é liberdade. Já é uma forma de negá-la e } \\
\text { destruí-la. E isto não podemos aceitar. }\end{array}$ \\
\hline
\end{tabular}




\begin{tabular}{|c|c|}
\hline & $\begin{array}{l}\text { O movimento que se fêz foi para restaurar a disciplina, a ordem, o regime. } \\
\text { Não se pode em nome dêste movimento estabelecer a indisciplina, a } \\
\text { desordem e a ilegalidade. } \\
\text { A Polícia da Guanabara não pode prender jornalista, nem invadir o domicílio } \\
\text { de ninguém, cuja inviolabilidade é garantida pela Constituição. Não pode ser } \\
\text { usada como simples arma política para o aniquilamento dos adversários de } \\
\text { um candidato à Presidência. Não pode ocupar os edifícios federais, pois o } \\
\text { país já tem um nôvo e legítimo presidente da República. O sr. Carlos } \\
\text { Lacerda tem de responder pelos crimes que histericamente vem praticando } \\
\text { contra o povo. } \\
\text { O que se passa no Estado da Guanabara é semelhante ao que se passa em } \\
\text { São Paulo. O sr. Ademar de Barros se julga com o direito de nomear } \\
\text { interventores para os órgãos oficiais e de ameaçar o Congresso. } \\
\text { Querem, tanto o governador da Guanabara como o governador de São } \\
\text { Paulo, que o Congresso eleja imediatamente um presidente da República e } \\
\text { que êste presidente seja apartidário. } \\
\text { O Congresso Nacional é soberano e não pode agir sob pressão de ninguém. } \\
\text { Assim como reagiu contra o sr. João Goulart deve reagir contra os srs. } \\
\text { Ademar de Barros e Carlos Lacerda. } \\
\text { O sr. Ranieri Mazzilli é o presidente da República e o Exército e o povo, que } \\
\text { querem preservar a Constituição, a legalidade, a disciplina e o regime } \\
\text { democrático, têm obrigação de estar ao seu lado neste momento e recusar } \\
\text { qualquer ameaça, o que seria uma humilhação imposta à Nação inteira. } \\
\text { O afastamento do sr. João Goulart foi precisamente para garantir as } \\
\text { instituições em vigor e não para atentar contra elas. } \\
\text { O país não recua nesta hora em que dará um passo à frente para a } \\
\text { consolidação de um regime social e político que conquistou através de uma } \\
\text { grande luta pela democracia. }\end{array}$ \\
\hline & Texto 10 \\
\hline $\begin{array}{l}\text { Gênero de } \\
\text { discurso }\end{array}$ & Notícia \\
\hline Título & Ex-ministros detidos e soltos em SP \\
\hline $\begin{array}{l}\text { Corpo do } \\
\text { texto }\end{array}$ & $\begin{array}{l}\text { Depois de prestar depoimento aos militares, o sr. Abelardo Jurema foi solto, } \\
\text { devendo reassumir a sua cadeira de deputado federal. A detenção do ex- } \\
\text { ministro da Justiça foi feita por oficiais da Escola do Estado-Maior do } \\
\text { Exército, tendo sido êle levado à Praia Vermelha, onde lhe foram pedidas } \\
\text { explicações. Segundo os militares, a prisão deveu-se ao fato de ter o sr. } \\
\text { Jurema "tentado insuflar o povo contra as Fôrças Armadas no momento em } \\
\text { que elas se empenhavam em restabelecer a ordem". Esta madrugada } \\
\text { também foi sôlto o marechal Osvino Alvez. } \\
\text { SÃO PAULO (Sucursal) - Quando transitavam, na tarde de ontem, por } \\
\text { Congonhas, procedentes de Pôrto Alegre, a caminho de Brasília, foram } \\
\text { detidos por policiais, o senador Amauri Silva, ex-ministro do Trabalho, } \\
\text { deputado federal Wilson Fadul, ex-ministro da Saúde, deputado federal } \\
\text { Osvaldo Lima Filho, ex-ministro da Agricultura, e os deputados federais } \\
\text { Aldévio Viana e Paulo Mincaroni, todos do PTL gaúcho. } \\
\text { Os parlamentares permaneceram detidos dentro da aeronave cêrca de cinco } \\
\text { horas. Por volta das } 20 \text { horas, chegou ao local o major Vinicius Kruel, a fim }\end{array}$ \\
\hline
\end{tabular}




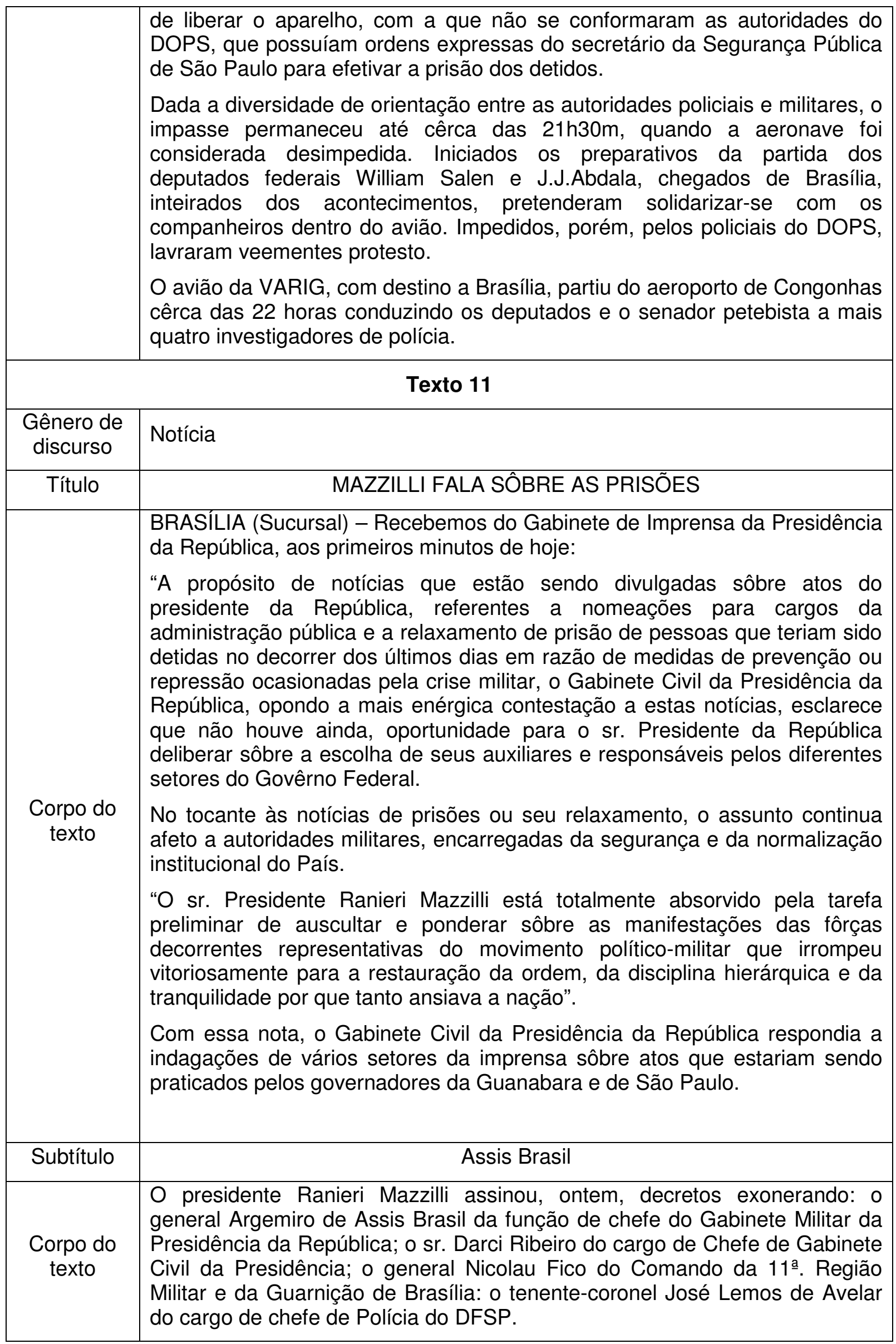




\begin{tabular}{|c|c|}
\hline & $\begin{array}{l}\text { O sr. Ranieri Mazzilli assinou, também atos nomeando: o general Rafael de } \\
\text { Souza Aguiar para o comando da } 11^{a} \text {. Região Militar e da Guarnição de } \\
\text { Brasília; o sr. Getúlio Moura para o cargo de ministro extraordinário para } \\
\text { assuntos do Gabinete Civil: o tenente-coronel Antônio Barbosa de Paula } \\
\text { Serra para chefe de Polícia do DFSP: o general André Fernandes de Souza } \\
\text { para chefe interino do Gabinete Militar: o sr. Gilberto Amado Pereira Alves } \\
\text { para seu secretário particular; e os srs. Reinaldo Gonçalves Ribeiro, Orlando } \\
\text { Pinto de Almeida e Adroaldo Lopes de Fonseca para oficiais do seu } \\
\text { Gabinete. }\end{array}$ \\
\hline Subtítulo & Posse \\
\hline $\begin{array}{l}\text { Corpo do } \\
\text { texto }\end{array}$ & $\begin{array}{l}\text { "Orgulho-me, como brasileiro, em proclamar que reina absoluta ordem em } \\
\text { todo o País, graças à nobre e patriótica atuação das Fôrças Armadas que, } \\
\text { mais uma vez, com sua desambição e fidelidade à causa constitucional, } \\
\text { assegura à família brasileira a continuidade da ordem democrática, sob } \\
\text { inspiração de Deus e rigoroso respeito aos direitos e garantias } \\
\text { constitucionais" - disse o sr. Ranieri Mazzilli ontem, às 3h20m, no Palácio do } \\
\text { Planalto, ao entrar efetivamente no exercício da Presidência da República. }\end{array}$ \\
\hline \multicolumn{2}{|r|}{ Texto 12} \\
\hline $\begin{array}{l}\text { Gênero de } \\
\text { discurso }\end{array}$ & Notícia \\
\hline Título & Seixas Dória chega prêso a Salvador \\
\hline $\begin{array}{l}\text { Corpo do } \\
\text { texto }\end{array}$ & $\begin{array}{l}\text { SALVADOR (Do correspondente) - Chegou ontem a esta capital, prêso, o } \\
\text { governador de Sergipe, sr. Seixas Dória. O político sergipano foi recolhido, } \\
\text { incomunicável, do quartel do 19‥ Batalhão de Caçadores do Exército. }\end{array}$ \\
\hline \multicolumn{2}{|r|}{ Texto 13} \\
\hline $\begin{array}{l}\text { Gênero de } \\
\text { discurso }\end{array}$ & Notícia \\
\hline Título & Bancos só abrirão 2a ${ }^{\mathrm{a}}$-feira \\
\hline $\begin{array}{l}\text { Corpo do } \\
\text { texto }\end{array}$ & $\begin{array}{l}\text { O comércio e a indústria funcionarão, normalmente, no dia de hoje, enquanto } \\
\text { que a reabertura dos bancos está prevista somente para segunda-feira, no } \\
\text { horário normal: das } 9 \text { às } 16 \mathrm{~h} \text {. Por seu turno, o senhor José Carlos de } \\
\text { Noronha, chefe de gabinete da Diretoria de Aeronáutica Civil, anunciou } \\
\text { estarem normalizadas, desde as } 8 \mathrm{~h} \text { de ontem, as operações de vôo nos } \\
\text { aeroportos do Galeão e Santos Dumont, ambos interditados, desde o início } \\
\text { da crise. }\end{array}$ \\
\hline
\end{tabular}




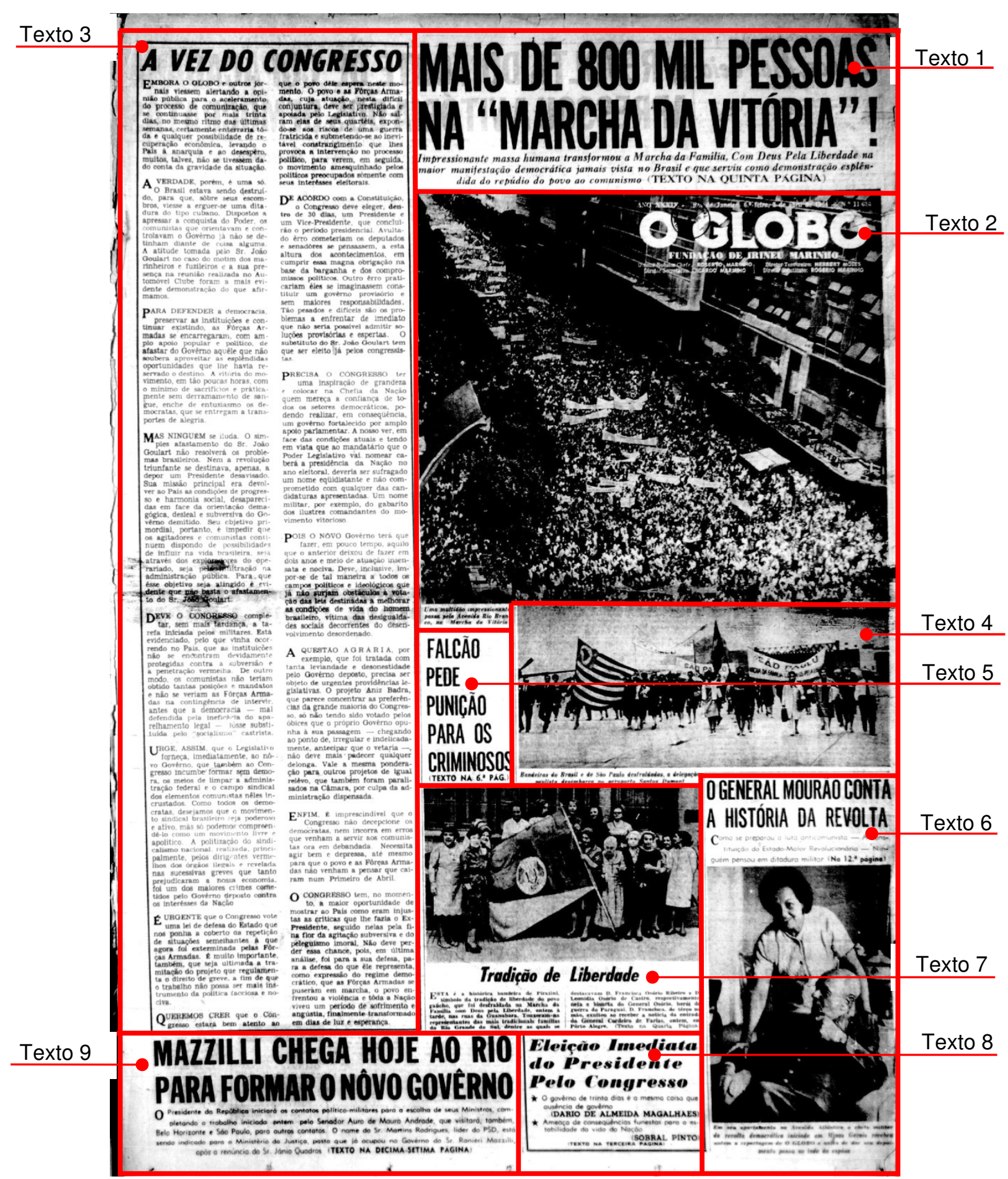

Figura 8 - Primeira página d'O Globo, edição de 03.04.1964. 
Quadro 5 - Transcrição da primeira página d'O Globo de 03.04.1964

\begin{tabular}{|c|c|}
\hline \multicolumn{2}{|r|}{ Texto 1} \\
\hline $\begin{array}{l}\text { Gênero de } \\
\text { discurso }\end{array}$ & Manchete (com chamada para aprofundamento) \\
\hline Título & MAIS DE 800 MIL PESSOAS NA "MARCHA DA VITÓRIA"! \\
\hline $\begin{array}{l}\text { Chamada } \\
\text { para } \\
\text { aprofunda } \\
\text { mento }\end{array}$ & $\begin{array}{l}\text { Impressionante massa humana transformou a Marcha da Família, Com Deus } \\
\text { Pela Liberdade na maior manifestação democrática jamais vista no Brasil e que } \\
\text { serviu como demonstração esplêndida do repúdio do povo ao comunismo } \\
\text { (TEXTO NA QUINTA PÁGINA) }\end{array}$ \\
\hline \multicolumn{2}{|r|}{ Texto 2} \\
\hline $\begin{array}{l}\text { Gênero de } \\
\text { discurso }\end{array}$ & Foto-manchete \\
\hline \multicolumn{2}{|l|}{$\begin{array}{l}\text { Imagem } \\
\text { fotográfica }\end{array}$} \\
\hline Legenda & $\begin{array}{l}\text { Uma multidão impressionante passa pela Avenida Rio Branco, na Marcha da } \\
\text { Vitória }\end{array}$ \\
\hline \multicolumn{2}{|r|}{ Texto 3} \\
\hline $\begin{array}{l}\text { Gênero de } \\
\text { discurso }\end{array}$ & Editorial \\
\hline Título & A VEZ DO CONGRESSO \\
\hline $\begin{array}{l}\text { Corpo do } \\
\text { texto }\end{array}$ & $\begin{array}{l}\text { EMBORA O GLOBO e outros jornais viessem alertando a opinião pública para } \\
\text { o aceleramento do processo de comunização, que se continuasse por mais } \\
\text { trinta dias, no mesmo ritmo das últimas semanas, certamente enterraria tôda e } \\
\text { qualquer possibilidade de recuperação econômica, levando o País à anarquia e } \\
\text { ao desespêro, muitos, talvez, não se tivessem dado conta da gravidade da } \\
\text { situação. }\end{array}$ \\
\hline
\end{tabular}


A VERDADE, porém, é uma só. O Brasil estava sendo destruído, para que, sôbre seus escombros, viesse a erguer-se uma ditadura do tipo cubano. Dispostos a apressar a conquista do Poder, os comunistas que orientavam e controlavam o Govêrno já não se detinham diante de coisa alguma. A atitude tomada pelo Sr. João Goulart no caso do motim dos marinheiros e fuzileiros e a sua presença na reunião realizada no Automóvel Clube foram a mais evidente demonstração do que afirmamos.

PARA DEFENDER a democracia, preservar as instituições e continuar existindo, as Fôrças Armadas se encarregavam, com amplo apoio popular e político, de afastar do Govêrno aquêle que não soubera aproveitar as esplêndidas oportunidades que the havia reservado o destino. A vitória do movimento em tão poucas horas, com o mínimo de sacrifício e práticamente sem derramamento de sangue, enche de entusiasmo os democratas, que se entregam a transportes de alegria.

MAS NINGUÉM se iluda. O simples afastamento do Sr. João Goulart não resolverá os problemas brasileiros. Nem a revolução triunfante se destinava, apenas a depor um Presidente desavisado. Sua missão principal era devolver ao País as condições de progresso e harmonia social, desaparecidas em face da orientação demagógica, desleal e subversiva do Govêrno demitido. Seu objetivo primordial, portanto, é impedir que os agitadores e comunistas continuem dispondo de possibilidades de influir na vida brasileira, seja através dos exploradores do operariado, seja pela infiltração na administração pública. Para que êsse objetivo seja atingido é evidente que não basta o afastamento do Sr. João Goulart.

DEVE O CONGRESSO completar, sem mais tardança, a tarefa iniciada pelos militares. Está evidenciado, pelo que vinha ocorrendo no País, que as instituições não se encontram devidamente protegidas contra a subversão e a penetração vermelha. De outro modo, os comunistas não teriam obtido tantas posições e mandatos e não se veriam as Fôrças Armadas na contingência de intervir antes que a democracia - mal defendida pela ineficácia do aparelhamento legal - fosse substituída pelo "socialismo" castrista.

URGE, ASSIM, que o Legislativo forneça, imediatamente, ao nôvo Govêrno, que também ao Congresso incumbe formar sem demora, os meios de limpar a administração federal e o campo sindical dos elementos comunistas nêles incrustados. Como todos os democratas, desejamos que o movimento sindical brasileiro seja poderoso e ativo, mas só podemos compreendê-lo como um movimento livre e apolítico. A politização do sindicalismo nacional realizada, principalmente, pelos dirigentes vermelhos dos órgãos ilegais e revelada nas sucessivas greves que tanto prejudicaram a nossa economia foi um dos maiores crimes cometidos pelo Govêrno deposto contra os interêsses da Nação.

É URGENTE que o Congresso vote uma lei de defesa do Estado que nos ponha a coberto da repetição de situações semelhantes à que agora foi exterminada pela Fôrças Armadas. É muito importante também, que seja ultimada a tramitação do projeto que regulamenta o direito de greve, a fim de que o trabalho não possa ser mais instrumento da política facciosa e nociva.

QUEREMOS CRER que o Congresso estará bem atento ao que o povo dêle espera neste momento. O povo e as Fôrças Armadas, cuja atuação, nesta difícil conjuntura, deve ser prestigiada e apoiada pelo Legislativo. Não saíram elas de seus quartéis, expondo-se aos riscos de uma guerra fratricida e submetendo-se ao inevitável constrangimento que lhes provoca a intervenção no processo político, para verem, em seguida, o movimento amesquinhado pelos políticos preocupados somente com seus interêsses eleitorais. 


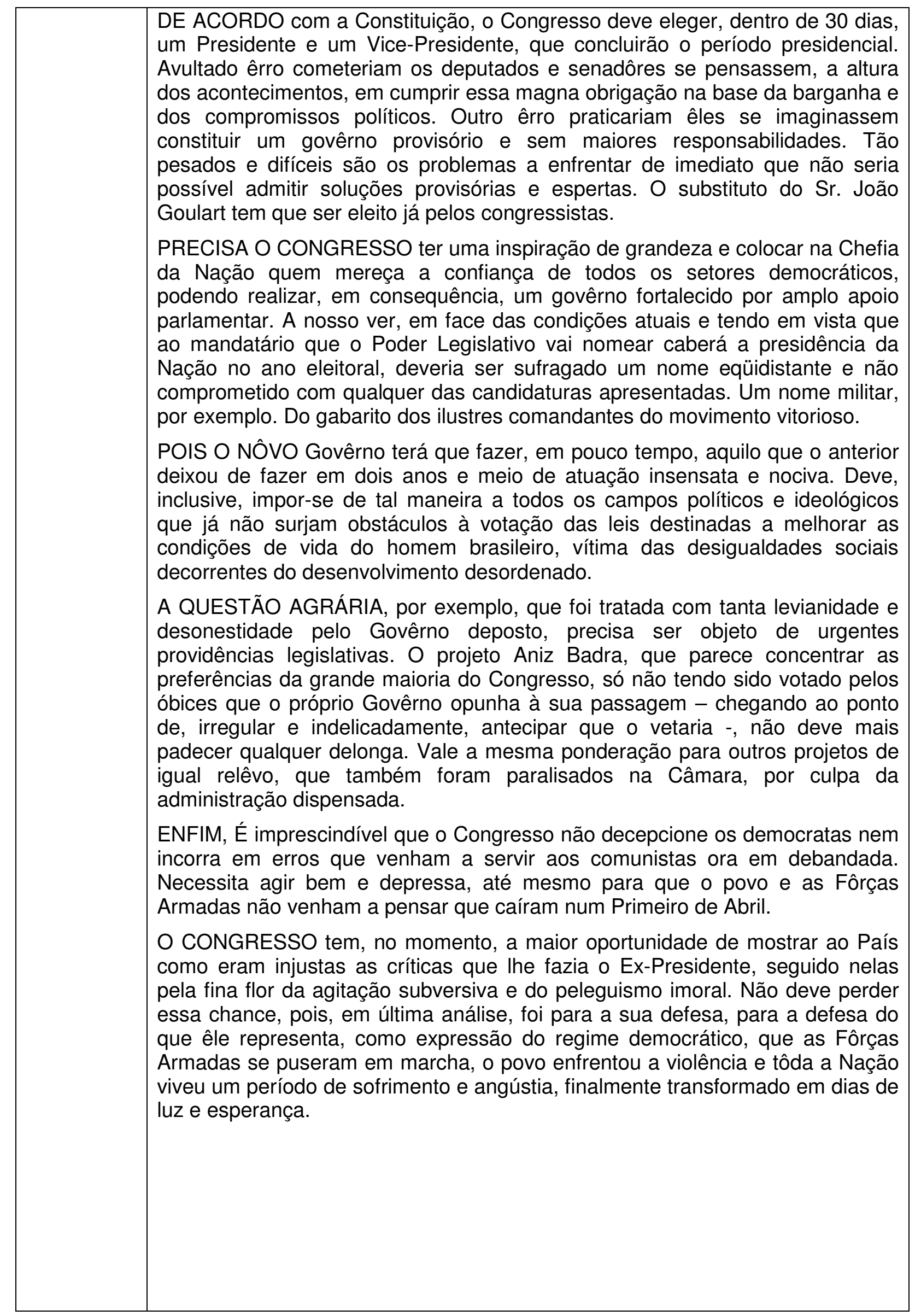




\begin{tabular}{|c|c|}
\hline & Texto 4 \\
\hline $\begin{array}{l}\text { Gênero de } \\
\text { discurso }\end{array}$ & Foto-legenda \\
\hline \multicolumn{2}{|l|}{$\begin{array}{l}\text { Imagem } \\
\text { fotográfica }\end{array}$} \\
\hline Legenda & $\begin{array}{l}\text { Bandeiras do Brasil e de São Paulo desfraldadas, a delegação paulista } \\
\text { desembarca no aeroporto Santos Dumont. }\end{array}$ \\
\hline \multicolumn{2}{|r|}{ Texto 5} \\
\hline $\begin{array}{l}\text { Gênero de } \\
\text { discurso }\end{array}$ & Chamada de capa para aprofundamento da notícia \\
\hline Título & $\begin{array}{l}\text { FALCÃO PEDE PUNIÇÃO PARA OS CRIMINOSOS } \\
\text { (TEXTO NA 6ª . PÁG.) }\end{array}$ \\
\hline \multicolumn{2}{|r|}{ Texto 6} \\
\hline $\begin{array}{l}\text { Gênero de } \\
\text { discurso }\end{array}$ & Foto-legenda (com chamada para aprofundamento) \\
\hline Título & O GENERAL MOURÃO CONTA A HISTÓRIA DA REVOLTA \\
\hline $\begin{array}{l}\text { Corpo do } \\
\text { texto }\end{array}$ & $\begin{array}{l}\text { Como se preparou a luta anticomunista - A constituição do Estado Maior } \\
\text { Revolucionário - Ninguém pensou em ditadura militar. ( } \mathrm{Na} 12^{\mathrm{a}} \text {. página) }\end{array}$ \\
\hline \multicolumn{2}{|l|}{$\begin{array}{l}\text { Imagem } \\
\text { fotográfica }\end{array}$} \\
\hline Legenda & $\begin{array}{l}\text { Em seu apartamento na Avenida Atlântica o chefe militar da revolta } \\
\text { democrática iniciada em Minas Gerais recebeu ontem a reportagem de O } \\
\text { GLOBO e antes de dar seu depoimento posou ao lado da espôsa. }\end{array}$ \\
\hline
\end{tabular}




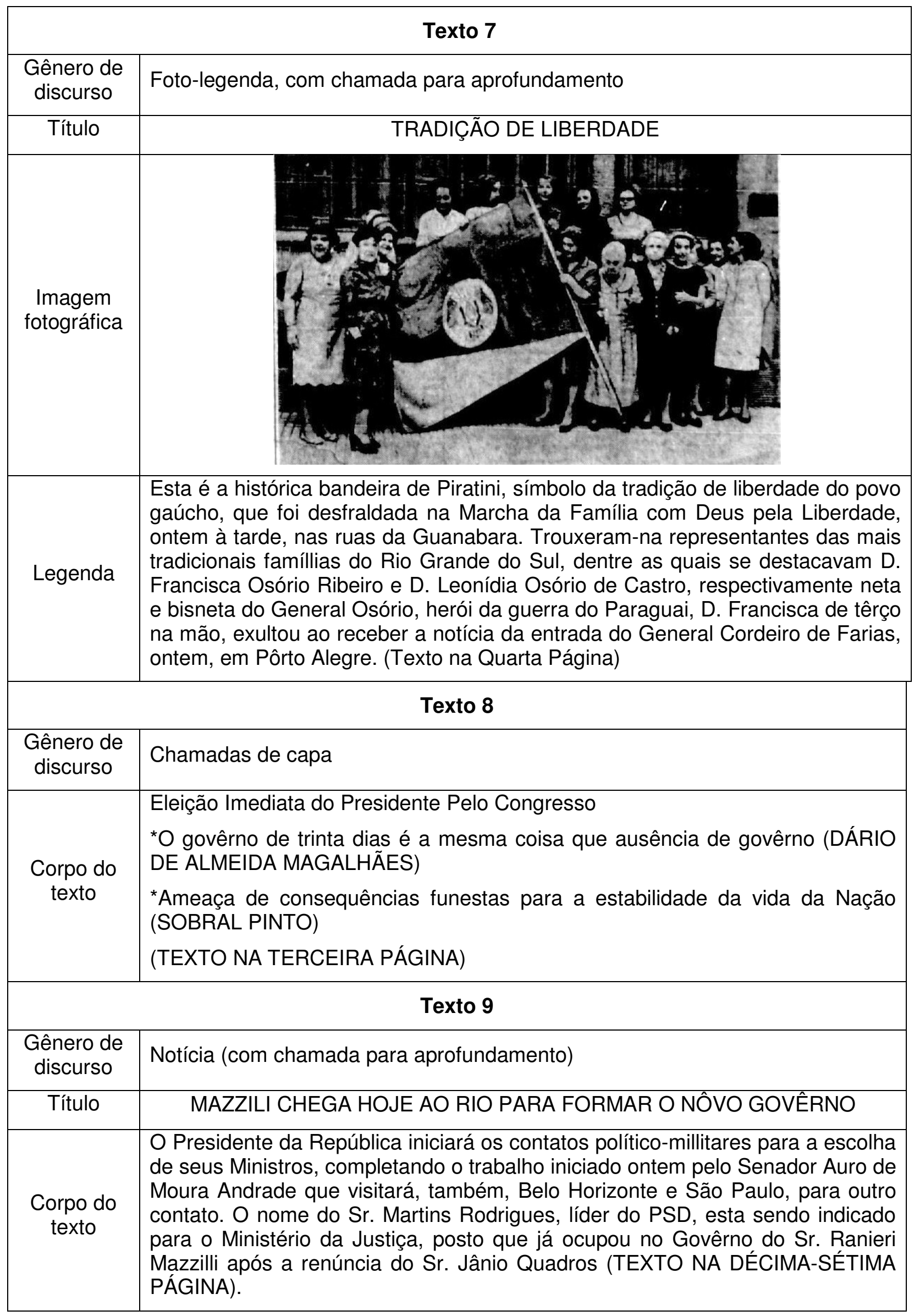




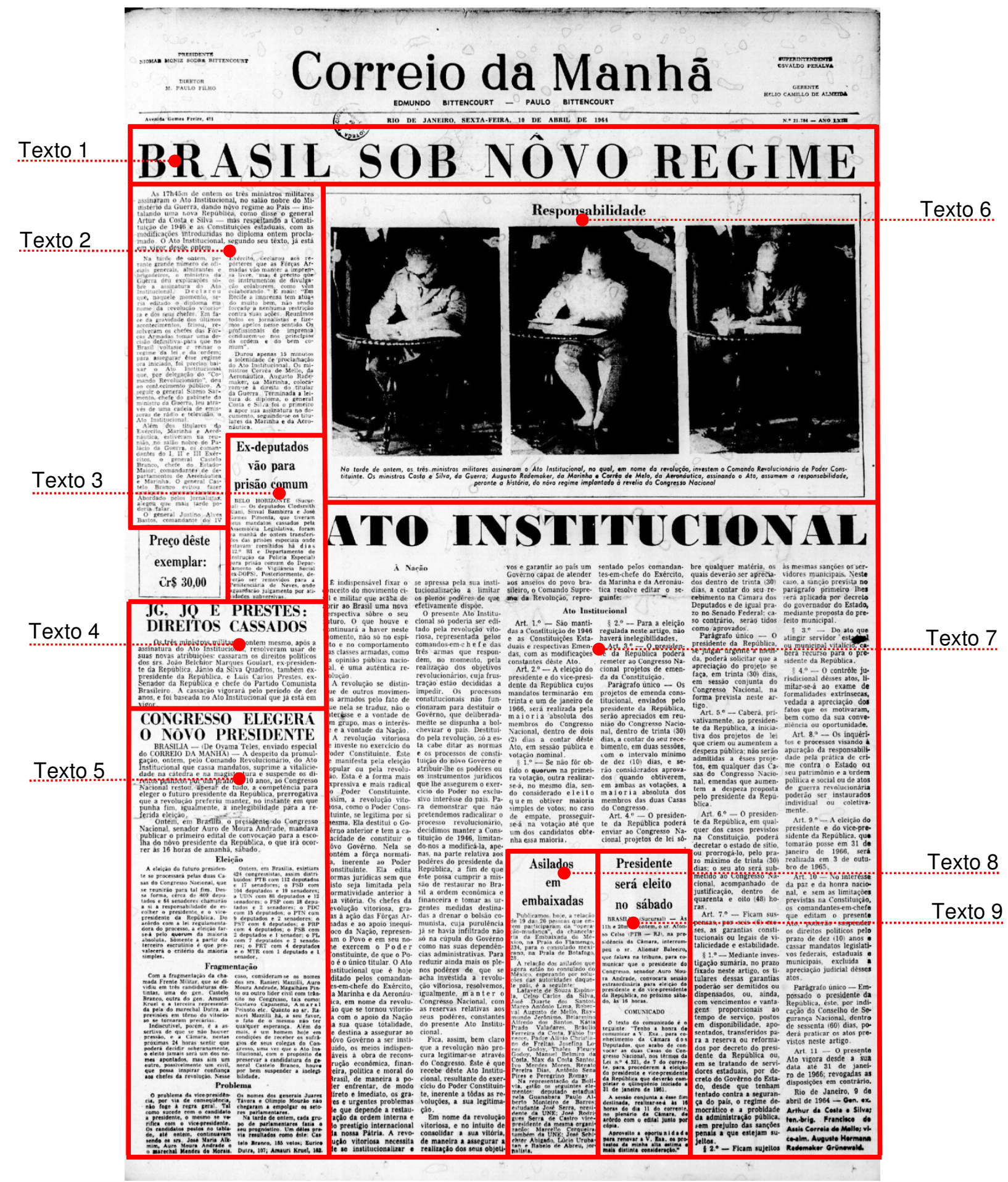

Figura 9 - Primeira página do Correio da Manhã, edição de 10.04.1964. 
Quadro 6 - Transcrição da primeira página do Correio da Manhã de 10.04.1964

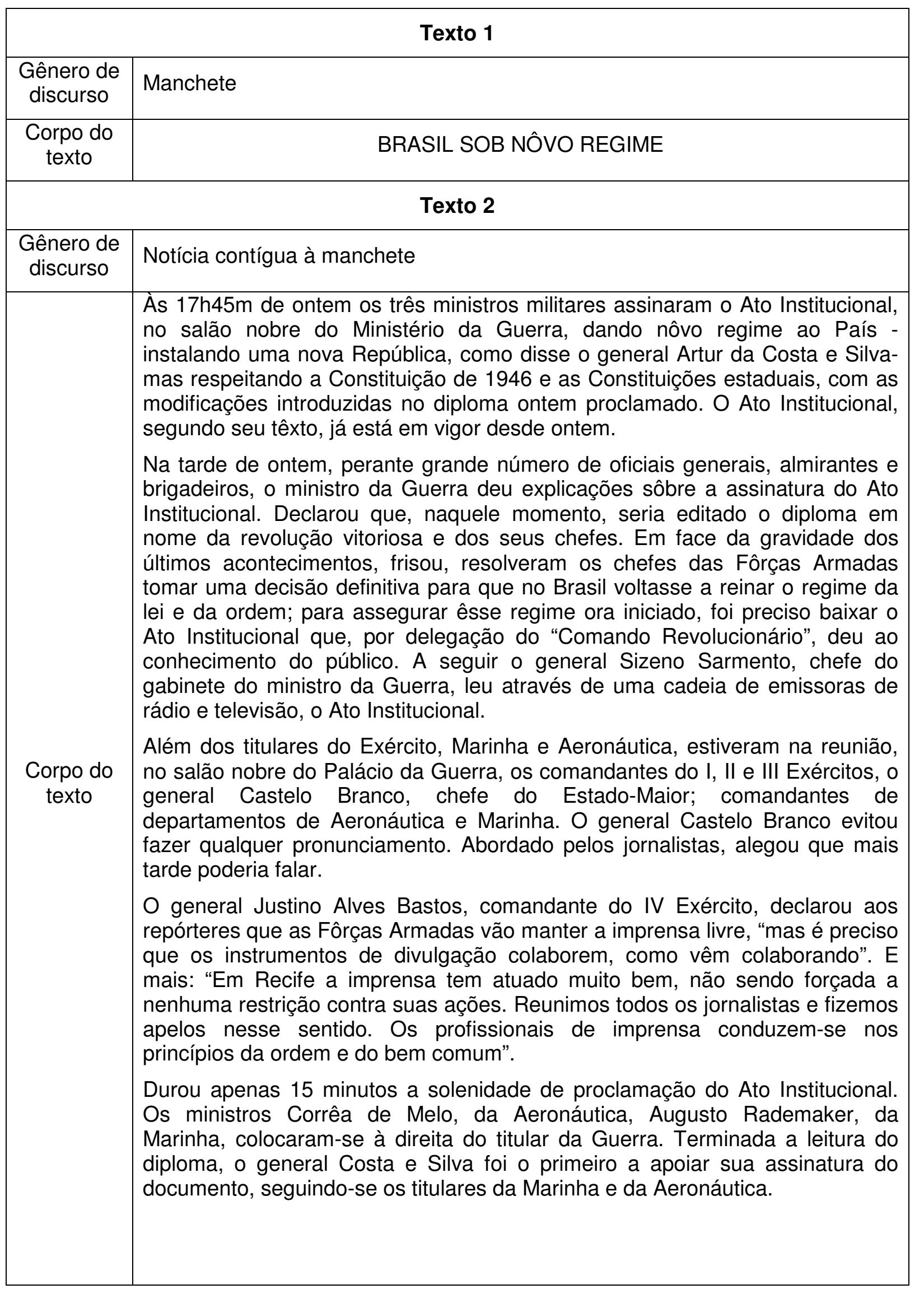




\begin{tabular}{|c|c|}
\hline \multicolumn{2}{|r|}{ Texto 3} \\
\hline $\begin{array}{l}\text { Gênero de } \\
\text { discurso }\end{array}$ & Notícia \\
\hline Título & Ex-deputados vão para prisão comum \\
\hline $\begin{array}{l}\text { Corpo do } \\
\text { texto }\end{array}$ & $\begin{array}{l}\text { BELO HORIZONTE (sucursal) - Os deputados Clodsmith Riani, Sinval } \\
\text { Bambirra e José Gomes Pimenta, que tiveram seus mandatos cassados pela } \\
\text { Assembléia Legislativa, foram na manhã de ontem transferidos das prisões } \\
\text { especiais onde estavam recolhidos há dias ( } 12^{\circ} \text { RI e Departamento de } \\
\text { Instrução da Polícia Especial) para prisão comum do Departamento de } \\
\text { Vigilância Social (ex-DOPS). Posteriormente, deverão ser removidos para a } \\
\text { Penitenciária de Neves, onde aguardarão julgamento por atividades } \\
\text { subversivas. }\end{array}$ \\
\hline \multicolumn{2}{|r|}{ Texto 4} \\
\hline $\begin{array}{l}\text { Gênero de } \\
\text { discurso }\end{array}$ & Notícia \\
\hline Título & JG, JQ E PRESTES: DIREITOS CASSADOS \\
\hline $\begin{array}{l}\text { Corpo do } \\
\text { texto }\end{array}$ & $\begin{array}{l}\text { Os três ministros militares, ontem mesmo, após a assinatura do Ato } \\
\text { Institucional, resolveram usar de suas novas atribuições: cassaram os direitos } \\
\text { políticos dos srs. João Belchior Marques Goulart, ex-presidente da República, } \\
\text { Jânio da Silva Quadros, também ex-presidente da República, e Luís Carlos } \\
\text { Prestes, ex-Senador da República e chefe do Partido Comunista Brasileiro. A } \\
\text { cassação vigorará pelo período de dez anos, e foi baseada no Ato Institucional } \\
\text { que já está em vigor. }\end{array}$ \\
\hline \multicolumn{2}{|r|}{ Texto 5} \\
\hline $\begin{array}{l}\text { Gênero de } \\
\text { discurso }\end{array}$ & Notícia \\
\hline Título & CONGRESSAO ELEGERÁ O NÔVO PRESIDENTE \\
\hline $\begin{array}{l}\text { Corpo do } \\
\text { texto }\end{array}$ & $\begin{array}{l}\text { BRASÍLIA- (De Oyama Teles, enviado especial do CORREIO DA MANHÃ) - A } \\
\text { despeito da promulgação, ontem, pelo Comando Revolucionário, do Ato } \\
\text { Institucional que cassa mandatos, suprime a vitaliciedade na cátedra e na } \\
\text { magistratura e suspende os direitos políticos por um prazo de } 10 \text { anos, ao } \\
\text { Congresso Nacional restou, apesar de tudo, a competência para eleger o futuro } \\
\text { presidente da República, prerrogativa que a revolução preferiu manter, no instante } \\
\text { em que punha fim, igualmente, à inelegibilidade para a referida eleição. } \\
\text { Ontem, em Brasília, o presidente do Congresso Nacional, senador Auro de } \\
\text { Moura Andrade, mandava publicar o primeiro edital de convocação para a } \\
\text { escolha do nôvo presidente da República, o que irá ocorrer às } 16 \text { horas de } \\
\text { amanhã, sábado. } \\
\text { Eleição } \\
\text { A eleição do futuro presidente se processará pelas duas Casas do Congresso } \\
\text { Nacional, que se reunirão para tal fim. Dessa forma, cêrca de } 409 \text { deputados } \\
64 \text { senadores chamarão a si a responsabilidade de escolher o presidente e o } \\
\text { vice-presidente da República. De acôrddo com a lei regulamentadora do } \\
\text { processo, a eleição far-se-á pelo quorum da maioria absoluta. Somente a } \\
\text { partir do terceiro escrutínio é que prevalecerá o critério da maioria simples. } \\
\text { Ontem em Brasília existiam } 424 \text { conaressistas, assim distribuídos: PTB com }\end{array}$ \\
\hline
\end{tabular}


112 deputados e 17 senadores; o PSD com 104 deputados e 19 senadores; a UDN com 88 deputados e 12 senadores; o PSP com 18 deputados e 2 senadores; o PDC com 15 deputados; o PTN com 9 deputados e 2 senadores; o PST com 6 deputados; o PRP com 4 deputados; o PSB com 2 deputados e 1 senador; o PL com 7 deputados e 2 senadores; o PRT com 4 deputados e 0 MTR com 1 deputado e 1 senador.

\section{Fragmentação}

Com a fragmentação da chamada Frente Militar, que se dividiu em três candidaturas distintas, uma do gen. Castelo Branco, outra do gen. Amauri Kruel e a terceira representada pelo marechal Dutra, as previsões em tôrno do vitorioso se tornaram precárias.

Indiscutível, porém, é a assertiva de que se não houver pressão, e a Câmara, nestas próximas 24 horas sentir que poderá decidir soberanamente, o eleito jamais será um dos nomes apontados, mas sim um outro, possivelmente um civil, que possa inspirar confiança aos chefes da revolução. Nesse caso, consideram-se os nomes dos srs. Ranieri Mazzilli, Auro Moura Andrade, Magalhães Pinto ou outro líder civil com trânsito no Congresso, tais como: Gustavo Capanema, Amaral Peixote etc. Quanto ao sr. Ranieri Mazzilli há, a seu favor, o fato de o mesmo não ter qualquer esperança. Além do mais, é um homem hoje em condições de receber os sufrágios de seus colegas do Congresso, uma vez que o Ato Institucional, com o propósito de preservar a candidatura do general Castelo Branco, houve por bem suspender a inelegibilidade.

\section{Problema}

O problema da vice-presidência, por via de conseqüência, não foge à regra geral. Tal como sucede com o candidato a presidente, o mesmo de verifica com o vice-presidente. Os candidatos postos no tablado, até ontem, continuavam sendo os srs. José Maria Alkmim, Auro Moura Andrade e o marechal Mendes de Morais. Os nomes dos generais Juarez Távora e Olímpio Mourão não chegaram a empolgar os setores parlamentares.

$\mathrm{Na}$ tarde de ontem, cada grupo de parlamentares fazia o seu prognóstico. Um dêles previa resultados como êste: Castelo Branco, 185 votos; Eurico Dutra, 107; Amauri Kruel, 162. 


\begin{tabular}{|c|c|}
\hline \multicolumn{2}{|r|}{ Texto 6} \\
\hline $\begin{array}{l}\text { Gênero de } \\
\text { discurso }\end{array}$ & Foto-manchete \\
\hline Título & bilidade \\
\hline $\begin{array}{l}\text { Imagem } \\
\text { fotográfica }\end{array}$ & 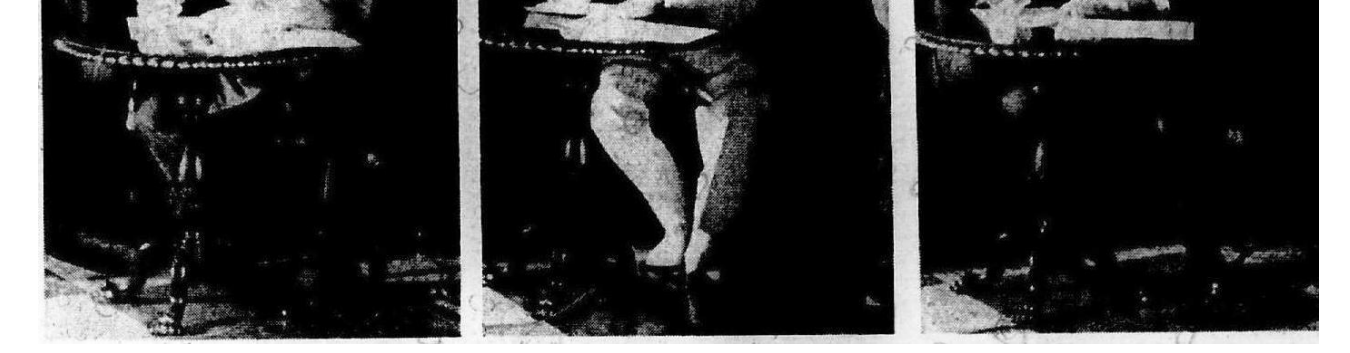 \\
\hline Legenda & $\begin{array}{l}\text { Na tarde de ontem, os três ministros militares assinaram o Ato Institucional, no } \\
\text { qual, em nome da revolução, investem o comando Revolucionário de Poder } \\
\text { Constituinte. Os ministros Costa e Silva, da Guerra; Augusto Rademaker, da } \\
\text { Marinha e Corrêa de Melo, da Aeronáutica, assinando o Ato, assumem a } \\
\text { responsabilidade, perante a história, do nôvo regime implantado à revelia do } \\
\text { Congresso Nacional. }\end{array}$ \\
\hline \multicolumn{2}{|r|}{ Texto 7} \\
\hline $\begin{array}{l}\text { Gênero de } \\
\text { discurso }\end{array}$ & Nota comentário relatado \\
\hline Título & ATO INSTITUCIONAL \\
\hline Subtítulo & À Nação \\
\hline $\begin{array}{l}\text { Corpo do } \\
\text { texto }\end{array}$ & $\begin{array}{l}\text { É indispensável fixar o conceito do movimento civil e militar que acaba de abrir } \\
\text { ao Brasil uma nova perspectiva sôbre o seu futuro. O que houve e continuará } \\
\text { a haver neste momento, não só no espírito e no comportamento das classes } \\
\text { armadas, como na opinião pública nacional, é uma autêntica revolução. } \\
\text { A revolução se distingue de outros movimentos armados pelo fato de que nela } \\
\text { se traduz, não o interêsse e a vontade de um grupo, mas o interêsse e a } \\
\text { vontade da Nação. } \\
\text { A revolução vitoriosa se investe no exercício do Poder Constituinte. Êste se } \\
\text { manifesta pela eleição popular ou pela revolução. Esta é a forma mais expressiva e } \\
\text { mais radical do Poder Constituinte. Assim, a revolução vitoriosa, como o Poder } \\
\text { Constituinte, se legitima por si mesma. Ela destitui o Govêrno anterior e tem a } \\
\text { capacidade de constituir o nôvo Govêrno. Nela se contém a fôrça normativa, } \\
\text { inerente ao Poder Constituinte. Ela edita normas jurídicas sem que nisto seja } \\
\text { limitada pela normatividade anterior à sua vitória. Os chefes da revolução vitoriosa, } \\
\text { graças à ação das Fôrças Armadas e ao apoio inequívoco da Nação, representam } \\
\text { o Povo e em seu nome exercem o Poder Constituinte, de que o Povo é o único } \\
\text { titular. O Ato Institucional que é hoje editado pelos comandantes-em-chefe do } \\
\text { Exército, da Marinha e da Aeronáutica, em nome da revolução que se tornou } \\
\text { vitoriosa com o apoio da Nação na sua quase totalidade, se destina a assegurar ao } \\
\text { nôvo Govêrno a ser instituído, os meios indispensáveis à obra de reconstrução }\end{array}$ \\
\hline
\end{tabular}




\begin{tabular}{|c|c|}
\hline & 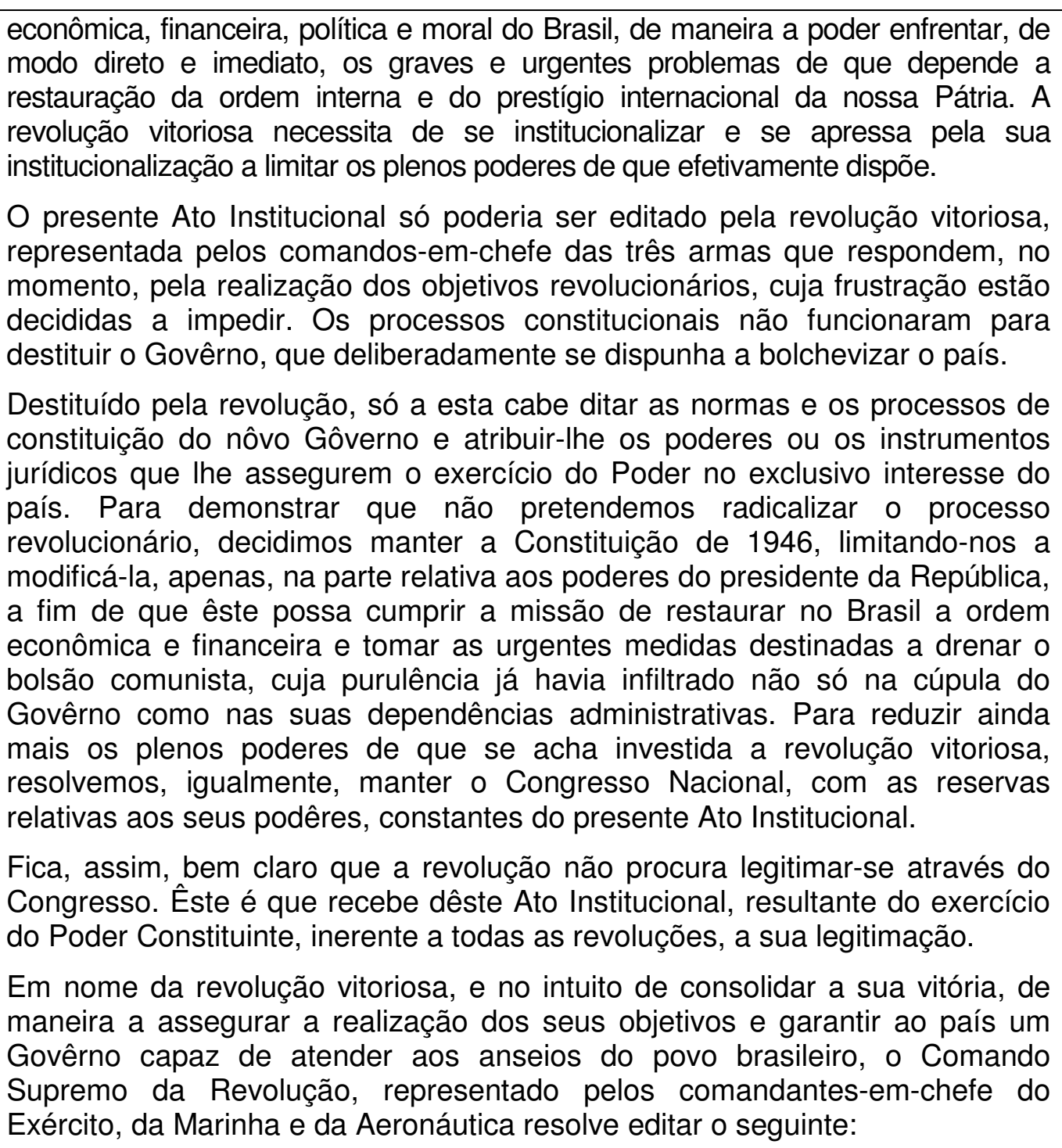 \\
\hline Subtítulo & Ato Institucional \\
\hline & $\begin{array}{l}\text { Art. 1. - - São mantidas a Constituição de } 1946 \text { e as Constituições Estaduais e } \\
\text { respectivas Emendas, com as modificações constantes dêste Ato. } \\
\text { Art. 2.o - A eleição do presidente e do vice-presidente da República cujos } \\
\text { mandatos terminarão em trinta e um de janeiro de 1966, será realizada pela } \\
\text { maioria absoluta dos membros do Congresso Nacional, dentro de dois (2) dias } \\
\text { a contar dêste Ato, em sessão pública e votação nominal. } \\
\text { § } 1 . . \text { - Se não fôr obtido o quorum na primeira votação, outra realizar-se-á, no } \\
\text { mesmo dia, sendo considerado eleito quem obtiver maioria simples de votos; } \\
\text { no caso de empate, prosseguir-se-á na votação até que um dos candidatos } \\
\text { obtenha essa maioria. } \\
\text { § 2.. - Para a eleição regulada neste artigo, não haverá inelegibilidades. } \\
\text { Art. 3. - - O presidente da República poderá remeter ao Congresso Nacional } \\
\text { projetos de emendas da Constituição. } \\
\text { Parágrafo único- Os projetos de emenda constitucional, enviados pelo } \\
\text { presidente da República, serão apreciados em reunião do Congresso } \\
\text { Nacional, dentro de trinta (30) dias, a contar do seu recebimento, em duas } \\
\text { sessões, com o intervalo mínimo de dez (10) dias, e serão considerados }\end{array}$ \\
\hline
\end{tabular}


aprovados quando obtiverem, em ambas as votações, a maioria absoluta dos membros das duas Casas do Congresso.

Art. 4..- O presidente da República poderá enviar ao Congresso Nacional projetos de lei sôbre qualquer matéria, os quais deverão ser apreciados dentro de trinta (30) dias, a contar do seu recebimento na Câmara dos Deputados e de igual prazo no Senado Federal; caso contrário, serão tidos como aprovados.

Parágrafo único- $O$ presidente da República, se julgar urgente a medida, poderá solicitar que a apreciação do projeto se faça, em trinta (30) dias, em sessão conjunta do Congresso Nacional, na forma prevista neste artigo.

Art. 5. - Caberá, privativamente, ao presidente da República, a iniciativa dos projetos de lei que criem ou aumentem a despeza pública; não serão admitidas a êsses projetos, em qualquer das Casas do Congresso Nacional, emendas que aumentem a despeza proposta pelo presidente da República.

Art. 6.-- O presidente da República, em qualquer dos casos previstos na Constituição, poderá decretar o estado de sítio, ou prorrogá-lo, pelo prazo máximo de trinta (30) dias; o seu ato será submetido ao Congresso Nacional, acompanhado de justificação, dentro de quarenta e oito (48) horas.

Art. $7 . .9-$ Ficam suspensas, por seis (6) meses, as garantias constitucionais ou legais de vitaliciedade e estabilidade.

$\S 1$.-- Mediante investigação sumária, no prazo fixado neste artigo, os titulares dessas garantias poderão ser demitidos ou dispensados, ou, ainda, com vencimento e vantagens proporcionais ao tempo de serviço, postos em disponibilidade, aposentados, transferidos para a reserva ou reformados por decreto do presidente da República ou, em se tratando de servidores estaduais, por decreto do Govêrno do Estado, desde que tenham tentado contra a segurança do país, o regime democrático e a probidade da administração pública, sem prejuízo das sanções penais a que estejam sujeitos.

$\S 2$. -. Ficam sujeitos às mesmas sanções os servidores municipais. Neste caso, a sanção prevista no parágrafo primeiro lhes será aplicada por decreto do governador do Estado, mediante proposta do prefeito municipal.

$\S 3$. - - Do ato que atingir servidor estadual ou municipal vitalício, caberá recurso para o presidente da República.

$\S$ 4.- $O$ contrôle jurisdicional dêsses atos, limitar-se-á ao exame de formalidades extrínsecas, vedada a apreciação dos fatos que os motivaram, bem como da sua conveniência ou oportunidade.

Art. $8^{\circ}$ - Os inquéritos e processos visando à apuração da responsabilidade pela prática de crime contra o Estado ou seu patrimônio e a ordem política e social ou de atos de guerra revolucionária poderão ser instaurados individual ou coletivamente.

Art. 9.-- A eleição do presidente e do vice-presidente da República, que tomarão posse em 31 de janeiro de 1966, será realizada em 3 de outubro de 1965.

Art. 10- No interêsse da paz e da honra nacional, e sem as limitações previstas na Constituição, os comandantes-em-chefe que editam o presente Ato, poderão suspender os direitos políticos pelo prazo de dez (10) anos e cassar mandatos legislativos federais, estaduais e municipais, excluída a apreciação judicial dêsses atos.

Parágrafo único- Empossado o presidente da República, êste, por indicação do Conselho de Segurança Nacional, dentro de sessenta (60) dias, poderá 


\begin{tabular}{|c|c|}
\hline & $\begin{array}{l}\text { praticar os atos previstos neste artigo. } \\
\text { Art. } 11 \text { - O presente Ato vigora desde a sua data até } 31 \text { de janeiro de 1966; } \\
\text { revogadas as disposições em contrário. } \\
\text { Rio de Janeiro, } 9 \text { de abril de 1964- Gen. ex. Arthur da Costa e Silva; ten.-brig. Francisco } \\
\text { de Assis Correia de Mello; vice-alm. Augusto Hermann Rademaker Grünewald. }\end{array}$ \\
\hline \multicolumn{2}{|r|}{ Texto 8} \\
\hline $\begin{array}{l}\text { Gênero de } \\
\text { discurso }\end{array}$ & Notícia \\
\hline Título & Asilados em embaixadas \\
\hline $\begin{array}{l}\text { Corpo do } \\
\text { texto }\end{array}$ & $\begin{array}{l}\text { Publicamos, hoje, a relação de } 19 \text { das } 20 \text { pessoas que ontem participaram da } \\
\text { "operação-mudança", da chancelaria da Embaixada do México, na Praia do } \\
\text { Flamengo, 334, para o consulado mexicano, na Praia de Botafogo, } 28 . \\
\text { A relação dos asilados que agora estão no consulado do México, esperando } \\
\text { por soluções das autoridades daquele país, é a seguinte: } \\
\text { Lafayete de Souza Espínola, Celso Carlos da Silva, José Duarte dos Santos, } \\
\text { Marco Antônio Lima, Roberval Augusto de Mello, Raymundo Jerônimo, } \\
\text { Belarmino Alfredo dos Santos, Kátia Prado Valadares, Bráulio Ferreira da } \\
\text { Costa, Fábio lunecco, Padre Alípio Christiano de Freitas, Josefina Lopes } \\
\text { Godoy, Thales Fleury Godoy, Manuel Belmiro da Costa, Max da Costa } \\
\text { Santos, Ivo Mendes Moren, Renato Pereira Dias, Antônio Sena Pires e } \\
\text { Peregrino Romay. } \\
\text { Na representação da Bolívia, estão os seguintes elementos: deputado } \\
\text { estadual pela Guanabara Paulo Alberto Monteiro de Barros; estudante José } \\
\text { Serra, presidente da UNE; José Rodrigues Serra de Castro vice-presidente da } \\
\text { mesma organização; Marcello Cerqueira, também da UNE; Schichter Abigado, } \\
\text { Lúcio Urubatan e Rabelo de Abreu, jornalista. }\end{array}$ \\
\hline \multicolumn{2}{|r|}{ Texto 9} \\
\hline $\begin{array}{l}\text { Gênero de } \\
\text { discurso }\end{array}$ & Notícia \\
\hline Título & Presidente será eleito no sábado \\
\hline $\begin{array}{l}\text { Corpo do } \\
\text { texto }\end{array}$ & $\begin{array}{l}\text { BRASÍLIA (Sucursal) - Às } 11 \mathrm{~h} \text { e } 20 \mathrm{~m} \text { de ontem, o sr. Afonso Celso (PTB - } \\
\text { RJ), na presidência da Câmara, interrompeu o sr. Aliomar Baleeiro, que falava } \\
\text { na tribuna, para comunicar que o presidente do Congresso, senador Auro } \\
\text { Moura Andrade, convocara sessão extraordinária para eleição do presidente e } \\
\text { do vice-presidente da República, no próximo sábado, às } 16 \text { horas. }\end{array}$ \\
\hline Subtítulo & COMUNICADO \\
\hline $\begin{array}{l}\text { Corpo do } \\
\text { texto }\end{array}$ & $\begin{array}{l}\text { O texto do comunicado é o seguinte: "Tenho a honra de comunicar a V. Exa., } \\
\text { para conhecimento da Câmara dos Deputados, que acabo de convocar as duas } \\
\text { Casas do Congresso Nacional, nos têrmos da Lei no } 4.321 \text {, de } 7 \text { do corrente, } \\
\text { para procederem à eleição do presidente e vice-presidente da República que } \\
\text { deverão completar o qüinqüênio iniciado a } 31 \text { de janeiro de } 1961 \text {. } \\
\text { A sessão conjunta a êsse fim destinada, realizar-se-á às } 15 \text { horas do dia } 11 \\
\text { do corrente, no plenário da Câmara, de acôrdo com o edital junto por cópia. } \\
\text { Aproveito a oportunidade para renovar a V. Exa. os protestos da minha alta } \\
\text { estima e mais distinta consideração." }\end{array}$ \\
\hline
\end{tabular}


3.3.3.2 O Globo, 10.04.1964

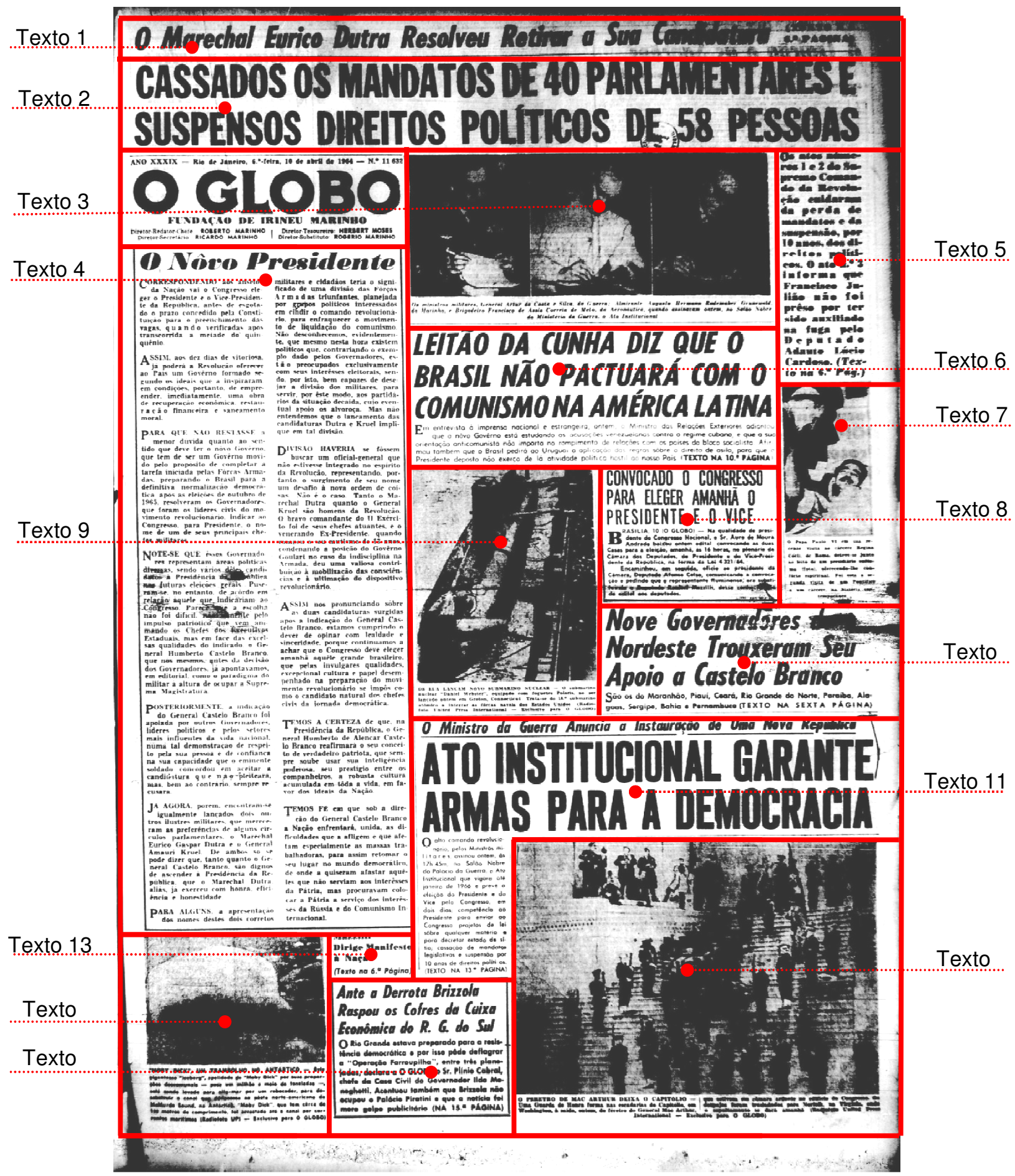

Figura 10 - Primeira página d'O Globo, edição de 10.04.1964. 
Quadro 7 - Transcrição da primeira página d'O Globo 10.04.1964

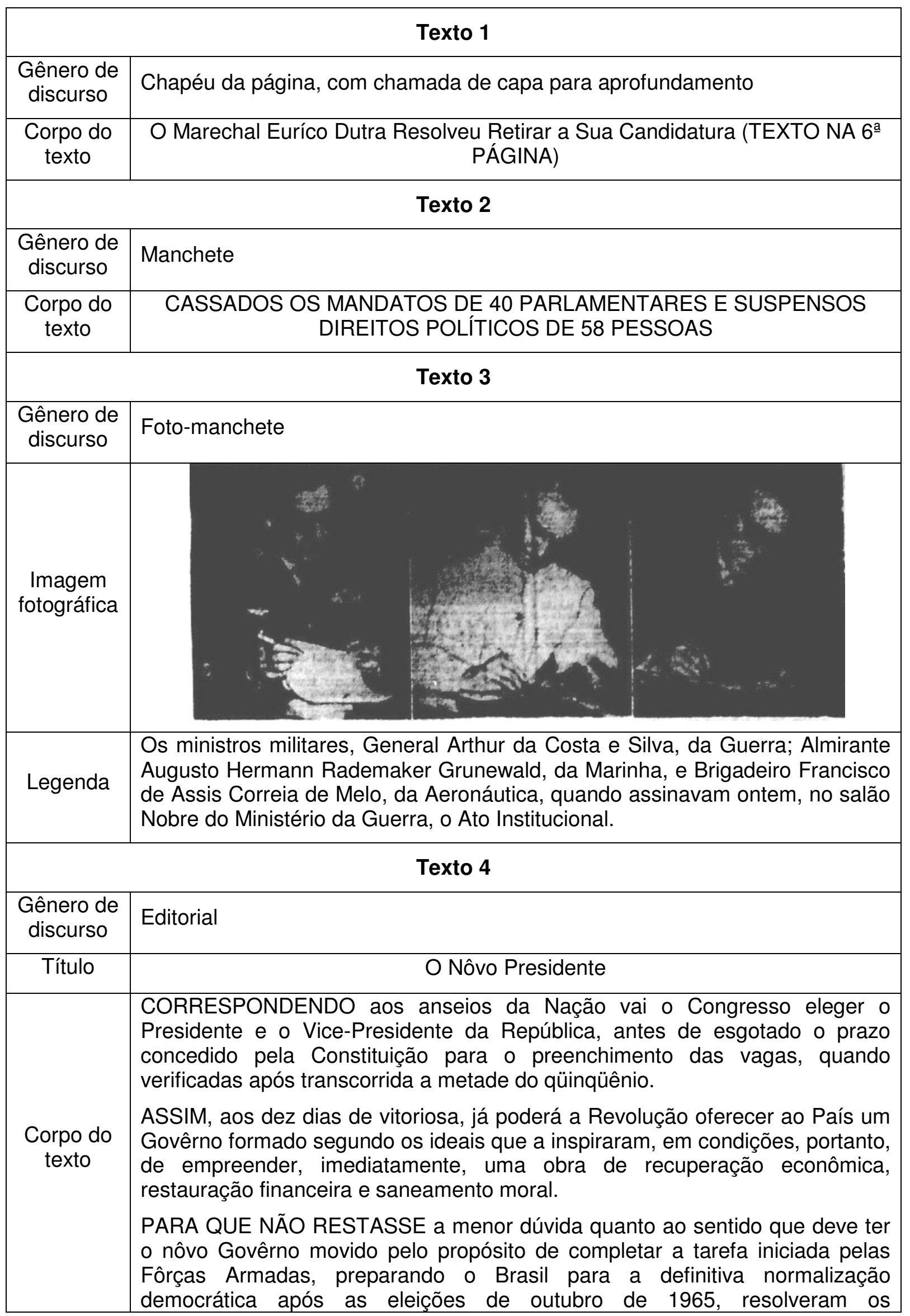


Governadores, que foram os líderes civis do movimento revolucionário, indicar ao Congresso, para Presidente, o nome de um de seus principais chefes militares.

NOTE-SE QUE êsses Governadores representam áreas políticas diversas, sendo vários dêles candidatos à Presidência da República nas futuras eleições gerais. Puseram-se, no entanto, de acôrdo em relação àquele que indicariam ao Congresso. Parece que a escolha não foi difícil, [não somente] pelo impulso patriótico que vem animando os Chefes dos Executivos estaduais, mas em face das excelsas qualidades do indicado, o General Humberto Castelo Branco, que nós mesmos, antes da decisão dos Governadores, já apontávamos, em editorial, como o paradigma do militar à altura de ocupar a Suprema Magistratura.

POSTERIORMENTE, a indicação do General Castelo Branco foi apoiada por outros Governadores, líderes políticos e pelos setores mais influentes da vida nacional, numa tal demonstração de respeito pela sua pessoa e de confiança na sua capacidade que o eminente soldado concordou em aceitar a candidatura que não pleiteara, mas, bem ao contrário, sempre recusara.

JÁ AGORA, porém, encontram-se igualmente lançados dois outros ilustres militares, que mereceram as preferências de alguns círculos parlamentares, o Marechal Eurico Gaspar Dutra e o General Amauri Kruel. De ambos só se pode dizer que, tanto quanto o General Castelo Branco, são dignos de ascender à Presidência da República, que o Marechal Dutra, aliás, já exerceu com honra, eficiência e honestidade.

PARA ALGUNS, a apresentação dos nomes dêstes dois corretos militares e cidadãos teria o significado de uma divisão das Fôrças Armadas triunfantes, planejada por grupos políticos interessados em cindir 0 comando revolucionário, para enfraquecer o movimento de liquidação do comunismo. Não desconhecemos, evidentemente, que mesmo nesta hora existem políticos que, contrariando o exemplo dado pelos Governadores, estão preocupados exclusivamente com seus interesses eleitorais, sendo, por isto, bem capazes de desejar a divisão dos militares, para servir, por êste modo, aos partidários da situação decaída, cujo eventual apoio os alvoroça. Mas não entendemos que o lançamento das candidaturas Dutra e Kruel implique em tal divisão.

DIVISÃO HAVERIA se fôssem buscar um oficial-general que não estivesse integrado no espírito da Revolução, representando, portanto, o surgimento de seu nome um desafio à nova ordem de coisas. Não é o caso. Tanto o Marechal Dutra quanto o General Kruel são homens da Revolução. O bravo comandante do II Exército foi de seus chefes atuantes, e o venerando ExPresidente, quando rompeu o seu mutismo de 13 anos, condenando a posição do Govêrno Goulart no caso da indisciplina na Armada, deu uma valiosa contribuição à mobilização das consciências e à ultimação do dispositivo revolucionário.

ASSIM nos pronunciando sôbre as duas candidaturas surgidas após a indicação do General Castelo Branco, estamos cumprindo o dever de opinar com lealdade e sinceridade, porque continuamos a achar que o Congresso deve eleger amanhã aquêle grande brasileiro, que pelas invulgares qualidades, excepcional cultura e papel desempenhado na preparação do movimento revolucionário se impôs como o candidato natural dos chefes civis da jornada democrática.

TEMOS A CERTEZA de que, na Presidência da República, o General Humberto de Alencar Castelo Branco reafirmará o seu conceito de verdadeiro 


\begin{tabular}{|c|c|}
\hline & $\begin{array}{l}\text { patriota, que sempre soube usar sua inteligência poderosa, seu prestígio entre } \\
\text { os companheiros, a robusta cultura acumulada em toda a vida, em favor dos } \\
\text { ideais da Nação. } \\
\text { TEMOS FÉ em que sob a direção do General Castelo Branco a Nação } \\
\text { enfrentará, unida, as dificuldades que a afligem e que afetam especialmente } \\
\text { as massas trabalhadoras, para assim retomar o seu lugar no mundo } \\
\text { democrático, de onde a quiseram afastar aquêles que não serviam aos } \\
\text { interesses da Pátria, mas procuravam colocar a Pátria a serviço dos interesses } \\
\text { da Rússia e do Comunismo Internacional. }\end{array}$ \\
\hline \multicolumn{2}{|r|}{ Texto 5} \\
\hline $\begin{array}{l}\text { Gênero de } \\
\text { discurso }\end{array}$ & Notícia, com chamada de capa para aprofundamento da notícia \\
\hline $\begin{array}{l}\text { Corpo do } \\
\text { texto }\end{array}$ & $\begin{array}{l}\text { Os atos números } 1 \text { e } 2 \text { do Supremo Comando da Revolução cuidaram da } \\
\text { perda de mandatos e da suspensão, por } 10 \text { anos, dos direitos políticos. O ato } \\
\text { n. }-3 \text { informa que Francisco Julião não foi prêso por ter sido auxiliado na fuga } \\
\text { pelo Deputado Adauto Lúcio Cardoso. (Texto na 6. }{ }^{-} \text {Pág.) }\end{array}$ \\
\hline \multicolumn{2}{|r|}{ Texto 6} \\
\hline $\begin{array}{l}\text { Gênero de } \\
\text { discurso }\end{array}$ & Notícia, com chamada de capa para aprofundamento da notícia \\
\hline Título & $\begin{array}{c}\text { LEITÃO DA CUNHA DIZ QUE O BRASIL NÃO PACTUARÁ COM O } \\
\text { COMUNISMO NA AMÉRICA LATINA }\end{array}$ \\
\hline $\begin{array}{l}\text { Corpo do } \\
\text { texto }\end{array}$ & $\begin{array}{l}\text { Em entrevista à imprensa nacional e estrangeira, ontem, o Ministro das } \\
\text { Relações Exteriores adiantou que o nôvo Govêrno está estudando as } \\
\text { acusações venezuelanas contra o regime cubano e que a sua orientação } \\
\text { anticomunista não importa no rompimento de relações com os países do bloco } \\
\text { socialista. Afirmou também que o Brasil pedirá ao Uruguai a aplicação das } \\
\text { regras sôbre o direito de asilo, para que o Presidente deposto não exerça de lá } \\
\text { atividade política hostil ao nosso País (TEXTO NA 10. - PÁGINA) }\end{array}$ \\
\hline \multicolumn{2}{|r|}{ Texto 7} \\
\hline $\begin{array}{l}\text { Gênero de } \\
\text { discurso }\end{array}$ & Foto-legenda \\
\hline \multicolumn{2}{|l|}{$\begin{array}{l}\text { Imagem } \\
\text { fotográfica }\end{array}$} \\
\hline Legenda & $\begin{array}{l}\text { O Papa Paulo VI em sua recente visita ao cárcere Regina Coeli, de Roma, } \\
\text { deteve-se junto ao leito de um presidiário enfermo (foto), oferecendo-lhe } \\
\text { confôrto espiritual. Foi esta a segunda visita de um Pontífice a um cárcere, na } \\
\text { história contemporânea }\end{array}$ \\
\hline
\end{tabular}




\begin{tabular}{|c|c|}
\hline \multicolumn{2}{|r|}{ Texto 8} \\
\hline $\begin{array}{l}\text { Gênero de } \\
\text { discurso }\end{array}$ & Notícia \\
\hline Título & $\begin{array}{l}\text { CONVOCADO O CONGRESSO PARA ELEGER AMANHÃ O PRESIDENTE E } \\
\text { O VICE }\end{array}$ \\
\hline \multirow{2}{*}{$\begin{array}{l}\text { Corpo do } \\
\text { texto }\end{array}$} & $\begin{array}{l}\text { BRASÍLIA, } 10 \text { (O GLOBO) - Na qualidade de presidente do Congresso } \\
\text { Nacional, o Sr. Auro de Moura Andrade baixou ontem edital convocando as } \\
\text { duas Casas para a eleição, amanhã, às } 16 \text { horas, no plenário da Câmara dos } \\
\text { Deputados, do Presidente e do Vice-Presidente da República, na forma da Lei } \\
4321 / 64 \text {. }\end{array}$ \\
\hline & $\begin{array}{l}\text { Encaminhou, em seguida, ofício ao presidente da Câmara, Deputado Afonso } \\
\text { Celso, comunicando a convocação e pedindo que o representante fluminense, } \\
\text { ora substituindo o Deputado Ranieri Mazzilli, desse conhecimento do edital } \\
\text { aos deputados. }\end{array}$ \\
\hline \multicolumn{2}{|r|}{ Texto 9} \\
\hline $\begin{array}{l}\text { Gênero de } \\
\text { discurso }\end{array}$ & Foto-legenda \\
\hline \multicolumn{2}{|l|}{$\begin{array}{l}\text { Imagem } \\
\text { fotográfica }\end{array}$} \\
\hline Legenda & $\begin{array}{l}\text { OS EUA LANÇAM NÔVO SUBMARINO NUCLEAR- O submarino nuclear } \\
\text { "Daniel Webster", equipado com foguetes Polaris, ao ser lançado ontem em } \\
\text { Groton, Connectult. Trata-se do } 18^{\circ} \text { submarino atômico a integrar as forças } \\
\text { navais dos Estados Unidos (Radiofoto United Press Internacional- Exclusivo } \\
\text { para O GLOBO) }\end{array}$ \\
\hline \multicolumn{2}{|r|}{ Texto 10} \\
\hline $\begin{array}{l}\text { Gênero de } \\
\text { discurso }\end{array}$ & Notícia, com chamada de capa para aprofundamento da notícia \\
\hline Título & Nove Governadores do Nordeste Trouxeram Seu Apoio a Castelo Branco \\
\hline $\begin{array}{l}\text { Corpo do } \\
\text { texto }\end{array}$ & $\begin{array}{l}\text { São os do Maranhão, Piauí, Ceará, Rio Grande do Norte, Paraíba, Alagoas, } \\
\text { Sergipe, Bahia e Pernambuco (TEXTO NA SEXTA PÁGINA) }\end{array}$ \\
\hline
\end{tabular}




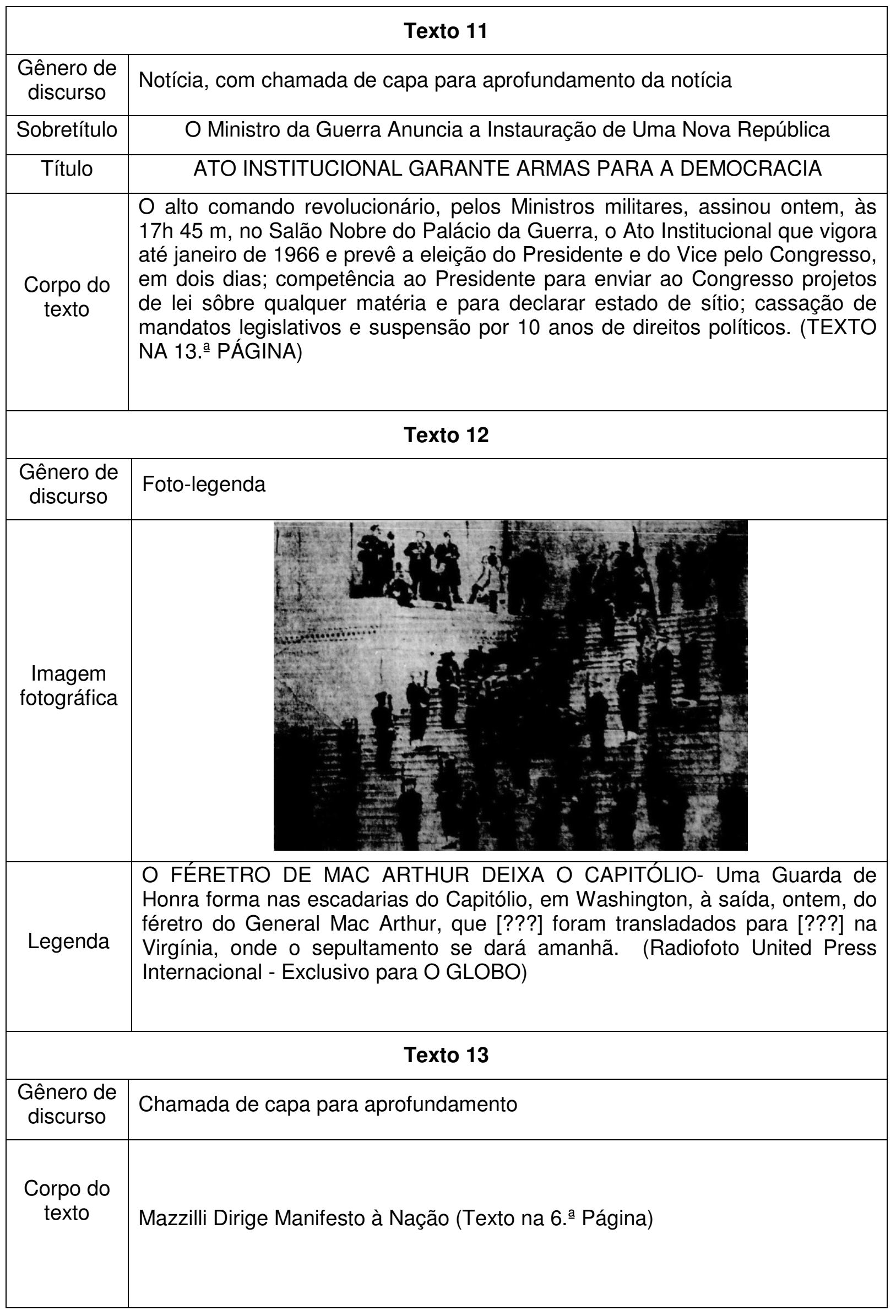




\begin{tabular}{|c|c|}
\hline \multicolumn{2}{|r|}{ Texto 14} \\
\hline $\begin{array}{l}\text { Gênero de } \\
\text { discurso }\end{array}$ & Foto-legenda \\
\hline \multicolumn{2}{|l|}{$\begin{array}{l}\text { Imagem } \\
\text { fotográfica }\end{array}$} \\
\hline Legenda & $\begin{array}{l}\text { "MOBY DICK", UM TRAMBOLHO NO ANTÁRTICO - Êste gigantesco } \\
\text { "iceberg", apelidado de "Moby Dick" por suas proporções descomunais- pesa } \\
\text { um milhão e meio de toneladas-, está sendo levado para alto-mar por um } \\
\text { rebocador, para desobstruir o canal que [???] norte-americano de [???], na } \\
\text { Antártica. "Moby Dick", que tem cerca de } 900 \text { metros de comprimento, foi } \\
\text { arrastado até o canal por correntes marítimas (Radiolete UPI- Exclusivo para } \\
\text { O GLOBO). }\end{array}$ \\
\hline \multicolumn{2}{|r|}{ Texto 15} \\
\hline $\begin{array}{l}\text { Gênero de } \\
\text { discurso }\end{array}$ & Notícia, com chamada de capa para aprofundamento da notícia \\
\hline Título & Ante a Derrota Brizzola Raspou os Cofres da Caixa Econômica do R.G. do Sul \\
\hline $\begin{array}{l}\text { Corpo do } \\
\text { texto }\end{array}$ & $\begin{array}{l}\text { O Rio Grande estava preparado para a resistência democrática e por isso } \\
\text { pôde deflagrar a "Operação Farroupilha", entre três planejadas, declara a O } \\
\text { GLOBO o Sr. Plínio Cabral, chefe da Casa Civil do Governador Ildo } \\
\text { Meneghetti. Aconteceu também que Brizzola não ocupou o Palácio Piratini e } \\
\text { que a notícia foi mero golpe publicitário (NA 15. İ PÁGINA) }\end{array}$ \\
\hline
\end{tabular}




\section{ANÁLISE DO CORPUS DA PESQUISA}

\subsection{O contexto sócio-histórico da produção dos discursos jornalísticos}

\subsubsection{O cenário político brasileiro em 1964 e as formações discursivas}

O cenário político internacional, entre 1945 e 1989, foi marcado pela "Guerra fria", advento em que os Estados Unidos da América (EUA) e a União das Repúblicas Socialistas Soviéticas (URSS), temendo perder o domínio político e econômico que haviam conquistado após a II Guerra Mundial, envolveram-se numa corrida armamentista, financiaram guerras civis e interferiram em governos de diversos países. Os Estados Unidos lançaram uma ofensiva anticomunista em todo o continente americano, com o objetivo de coibir medidas que, semelhantemente às adotadas por Fidel Castro (nacionalização de empresas norte-americanas, aproximação com URSS, entre outras), contrariavam seus interesses.

Inegavelmente, esses dois polos ideológicos que marcaram a guerra fria influenciaram a política brasileira, matizando as divergências políticas já existentes. Se o cenário político brasileiro em 1964 apresentava muitas tendências partidárias que representavam os interesses dos vários setores sócio-econômicos existentes no país, o Golpe de 64 (influenciado também pela guerra fria) criou um novo paradigma ao determinar a reorganização desses diversos setores em torno de apenas duas posições políticas e ideológicas marcadamente controversas, no sentido de que esses dois lados se apresentam como posições catalisadoras de distintas maneiras de apoiar e de se opor ao golpe, ou à revolução como preferem os apoiadores ao golpe.

É por meio da linguagem, seja ela verbal ou não-verbal, que são construídos os valores e as crenças em torno de cada posição ideológica, materializando em textos (escritos, orais, visuais, sincréticos ${ }^{44}$ etc.) os discursos em torno dessas posições. Nesse contexto, constituem-se, ao menos, duas formações ideológicas e duas formações discursivas, noções assim definidas por Michel Pêcheux (1997, p. 160):

Chamaremos, então, de formação discursiva aquilo que, numa formação ideológica dada, isto é, a partir de uma posição dada numa conjuntura dada, determinada pelo estado da luta de classes, determina $o$ que pode e deve ser dito (articulado sob a forma de uma arenga, de um sermão, de um panfleto, de uma exposição, de um programa etc.).

\footnotetext{
${ }^{44}$ Para explicar o que são os textos sincréticos, recorremos a Fiorin $(2006$, p. 3): "Ao lado das linguagens "simples", que se manifestam por um único meio de expressão, como a música ou a escrita alfabética, engendram-se linguagens 'complexas', que se externam por diversos meios de expressão".
} 
Grosso modo a formação ideológica determina o que pode e deve ser pensado, ao passo que a formação discursiva determina o que pode e deve ser dito. Essas duas noções discursivas são interessantes, pois nos permitem compreender que a atividade discursiva é uma prática submetida a restrições. A esse respeito, Foucault (2003 [1971], p. 9) afirma que "em toda sociedade a produção do discurso é ao mesmo tempo controlada, selecionada, organizada e redistribuída por certo número de procedimentos que têm por função conjurar seus poderes e perigos".

Os discursos favoráveis ao Golpe de 64, por exemplo, só são legítimos se obedecem às regras impostas tacitamente pela formação discursiva à qual se filiam, ou seja, em primeiro lugar, não entendem como golpe nem chamam de golpe militar a derrubada de João Goulart, mas sim a entendem como revolução e a chamam de "Revolução de março", "Revolução redentora" etc. E, à legitimação do discurso, subjaz um sujeito que assume um papel social ao qual se prescreve onde, quando, $o$ que e como ele pode e não pode dizer, o que remete à questão da identidade discursiva. Se a formação discursiva estabelece restrições que podem ser observadas no discurso, ao mesmo tempo ela engendra uma comunidade discursiva em torno de si, uma vez que os discursos não existem sem um sujeito, um corpo que enuncia. Desse modo, "revolucionários"e "antigolpistas" travaram um embate que se estendeu a várias esferas da atividade humana, entre elas a jornalística. 


\subsubsection{Composição das forças sociais ditas "revolucionárias"}

Mencionamos anteriormente que o acontecimento discursivo em torno do movimento político de abril de 1964 fincou duas posições ideológicas diametralmente opostas que, entretanto, serviram para catalisar os mais variados espectros ideológicos dispersos no tabuleiro político naquela ocasião. Parece-nos interessante, neste momento, fazer uma breve exposição acerca do processo de construção e de composição da força social que se empenhou diretamente na campanha de deposição de João Goulart. Para tanto, recorreremos ao trabalho de Dreifuss (1981), que apresenta de forma minuciosa a articulação política e militar arquitetada para a ação golpista: criação de uma organização institucional (IPES/IBAD); recrutamento de seus primeiros membros; sua expansão pelo país; sua associação com instituições congêneres em outros países; sua penetração nos diversos meios de atividade profissional da sociedade e atividade, bem como sua organização interna.

Dreifuss (1981, p. 161) apresenta, de um lado, uma classe de intelectuais orgânicos de interesses econômicos multinacionais e associados, a qual ele denomina "elite orgânica", e, de outro lado, o bloco populista oligárquico-industrial formado pelo governo nacional-reformista de João Goulart e pelo alinhamento das forças sociais que o apoiavam, como as classes trabalhadoras emergentes, bem como pelo bloco de poder tradicional e pela classe oligárquica, que, se não eram seus aliados de primeira hora, também não se alinhavam aos interesses defendidos pela elite orgânica. Com o objetivo de agir contra o governo de João Goulart, essa elite criou um complexo político-militar, o IPES/IBAD, Instituto de Pesquisas e Estudos Sociais/Instituto Brasileiro de Ação Democrática, partindo do projeto de uma reforma política à articulação de um golpe de Estado. Segundo Dreifuss (1981, p. 162), a razão para a desestabilização e derrubada do governo de João Goulart estava voltada para a "transposição do poder privado dos interesses multinacionais e associados para o governo público do Brasil".

Ainda, de acordo com Dreifuss (1981, p. 162), os interesses multinacionais e associados eram articulados, mas não tinham uma liderança política reconhecida $e$ organizada. Por essa razão, o papel do complexo IPES/IBAD era o de traduzir a consciência dessa organização, criando o grau de homogeneidade necessário à constituição dessa classe formada pelas mais distintas forças sociais burguesas. Os 
próprios fundadores do IPES/IBAD pertenciam a espectros ideológicos distintos, mas tinham em comum as relações econômicas multinacionais, o posicionamento anticomunista e a ambição de reformular o Estado (op. cit., p. 163).

Dreifuss (1981, p. 163-164) explica que o IPES/IBAD, no entanto, se mostrava como uma organização de homens de negócio e de intelectuais que tinham o objetivo de tão somente estudar, sob o ponto de vista liberal, as reformas de base de João Goulart. Os membros do IPES/IBAD se esforçavam para apresentar uma organização dirigida por empresários e profissionais liberais com orientação democrática e patriótica, a fim de escamotear seus interesses privados e de classe. Essa dupla vida política do complexo IPES/IBAD encobria uma coordenada e sofisticada campanha política, ideológica e militar que se destacava pela manipulação da opinião pública e pela guerra psicológica.

Uma das evidências de que a ação desse complexo se comportava como uma operação militar é que o recrutamento dos membros se dava na forma de células, ou seja, "organizavam e recrutavam um núcleo de 50 membros, cada um encarregado de trazer cinco outros, e eles, por sua vez, outros cinco. Eles concordavam em conduzir tanto as operações públicas, quanto as encobertas" (op. cit., p. 164). Assim, enquanto o IPES delineava as estratégias e se constituía como a inteligência da elite orgânica, o IBAD se responsabilizava pela ação propriamente dita, ou seja, os seus membros é que realizaram os ataques a figuras públicas por meio da mídia; que faziam pressão econômica sobre os empresários que não se encaixavam no perfil antigovernista; que repreendiam jornais que adotavam postura moderada contra o governo de João Goulart.

Com essa estrutura articulada, a elite orgânica tratou de cooptar grupos antigovernistas dispersos pelo país; de instituir organizações de cobertura para operações encobertas nos movimentos estudantis e operários; de estabelecer presença política no Congresso Nacional; de estabelecer controle efetivo da mídia audiovisual e da imprensa de todo país.

Interessa-nos ressaltar a preocupação da elite orgânica em criar uma consciência de classe para essa força social que se constituía a partir de distintas frações das classes dominantes:

Durante o período inicial do IPES, a elite orgânica disseminou entre as diferentes frações das classes dominantes a necessidade de se movimentar em torno da formação do espírito burguês de classe (DREIFUSS, 1981, p. 168). 
No entanto, um dos fatores de sucesso da estratégia de ampliação da ação política da elite orgânica foi o envolvimento de setores das classes médias e trabalhadoras na articulação antigovernista. E agregar as demandas dessas classes sociais, ainda que de forma aparente, foi um fator que levou o IPES a recuar em certos posicionamentos, ocasionando no que Dreifuss (1981, p. 178) chama de clivagem ideológica. Assim, temas até então preteridos pela elite orgânica, como o da reforma agrária, entram na pauta de discussão do IPES.

Essa ação estratégica coordenada pela elite orgânica encontrava suporte em seu Instituto de Pesquisa, o IPES, cuja estrutura interna contava com uma cadeia de unidades operacionais, chamadas de Grupos de Estudo e Ação, sendo que "esses grupos operavam em dez principais áreas de ação política e ideológica: nas Forças Armadas, Congresso, Executivo, classe empresarial, sindicatos, classe camponesa, Igreja, partidos políticos, mídia e nas camadas intermediárias” (op. cit., p. 185).

Vale destacar os grupos empenhados em agir especificamente na esfera midiática. Apoiando-se em documentos do IPES, Dreifuss (1981, p. 192) relata que o Grupo de Opinião Pública (GOP) visava à:

"[...] disseminação dos objetivos e atividades do IPES por meio da imprensa falada e escrita", levando "à opinião pública os resultados de sua pesquisa e estudos".

O Grupo de Publicações/Editorial (GPE) operava ao lado do GOP e, contando com escritores como José Rubem Fonseca e Raquel de Queiroz, era responsável por escrever, traduzir e publicar material impresso de cunho anticomunista e antipopulista, abrangendo formas de publicação como panfletos, jornais, revistas e livros.

Todavia, era o Grupo de Estudo e Doutrina (GED) que fornecia as bases ideológicas para a ação dos demais grupos. Como salienta Dreifuss (1981, p. 196), tal grupo constituía a 'estufa ideológica' do IPES. Ademais, a atuação do GED na mídia ocorria de maneira bem próxima:

Supervisionava ainda a ação do IPES na mídia, preparando os argumentos para exposição e discussão, fornecendo linhas ideológicas e, de fato, coordenando o material de propaganda relativo a figuras políticas importantes, sindicalistas, empresários e personalidades artísticas ou literárias a ser usado nas apresentações de televisão e programas regulares de rádio (DREIFUSS, 1981, p. 199). 
Com base no trabalho de Dreifuss, podemos concluir que a estratégia de ação política promovida pela elite orgânica do IPES teve como ponto-chave a dominação ideológica, a construção de um discurso hegemônico que pudesse suplantar quaisquer outros discursos contrários aos interesses multinacionais e associados.

Toledo (2006, p. 210) comenta que o IPES organizava palestras, cursos e seminários com o propósito de levar a sua ideologia "a recrutas e também para moldar a força social empresarial em um bloco burguês de poder". Através de seu trabalho de formação político-ideológica, o IPES visava se constituir numa espécie de anti-ISEB, lembrando que Dreifuss entende que o IPES se apresentava como "uma alternativa ao Instituto Superior de Estudos Brasileiros, o centro nacionalreformista de pesquisas e de formulação de opções políticas, que atraia acadêmicos, militares, jornalistas e estudantes" (DREIFUSS, 1981, p. 258).

O Instituto Superior de Estudos Brasileiros - ISEB - constituiu-se num dos mais ativos núcleos do debate em torno do nacional-desenvolvimentismo, durante quase uma década - de meados dos anos 50 até o golpe de 1964. O Instituto reuniu intelectuais e técnicos que proviam de diferentes formações filosóficas e ideológicas. Entre elas, o marxismo, a sociologia do conhecimento de Mannheim, a fenomenologia existencialista, o humanismo cristão etc.; ideologicamente, entre esses intelectuais encontravam-se, socialistas, liberais-democratas, católicos de esquerda e ex-integralistas.

No período do governo Goulart, o ISEB se engajou abertamente na defesa das reformas de base; como consequência dessa sua militância político-ideológica, a instituição foi - juntamente com outras entidades progressistas (UNE, CGT, PCB, Ligas camponesas etc.) - duramente reprimida, logo após o primeiro de abril de 1964 (TOLEDO, 2006, p. 21).

Assim, no que interessa à nossa análise, parece-nos que os elementos apontados até aqui irão nos fornecer subsídios para compreender o contexto sóciohistórico relativo à produção discursiva d'O Globo e do Correio da Manhã referente ao mês de abril de 1964. 


\subsection{O hipergênero “primeira página” no Correio da Manhã e n’O Globo}

\subsubsection{O discurso gráfico-visual dos jornais}

Nesta subseção, analisaremos a constituição hipergenérica da "primeira página do jornal”, examinando a inter-relação dos gêneros jornalísticos presentes na primeira página, no sentido de verificar como o intercâmbio entre as cenas genéricas e hipergenérica contribui para a construção do efeito de real e capta o imaginário do leitor, construindo, nesse processo, efeitos de identificação entre o jornal e seu leitor. Trata-se, portanto, de mostrar como o layout da primeira página revela a identidade discursiva de cada empresa jornalística, o que, no âmbito desta pesquisa, afigura-se como estratégia privilegiada do discurso jornalístico para conquistar a adesão do leitor aos seus posicionamentos. É, nesse sentido, que Maria Rosa Duarte de Oliveira (1993, p. 47-48) afirma que:

No caso específico do discurso jornalístico, a ação argumentativa não se reduz aos editoriais, onde, por estar a descoberto, é até menos convincente. É no "design" da página - nas redes diagramáticas das fotos, manchetes e submanchetes, tipos gráficos e textos - que a persuasão se faz iconicamente, de forma direta e mais eficaz.

Primeiramente, iremos observar, nas Figuras 11 e 12, a distribuição entre gêneros verbais (destacados em azul e também os não destacados) e verbo-visuais (destacados em vermelho) que é apresentada pelo layout de cada jornal:

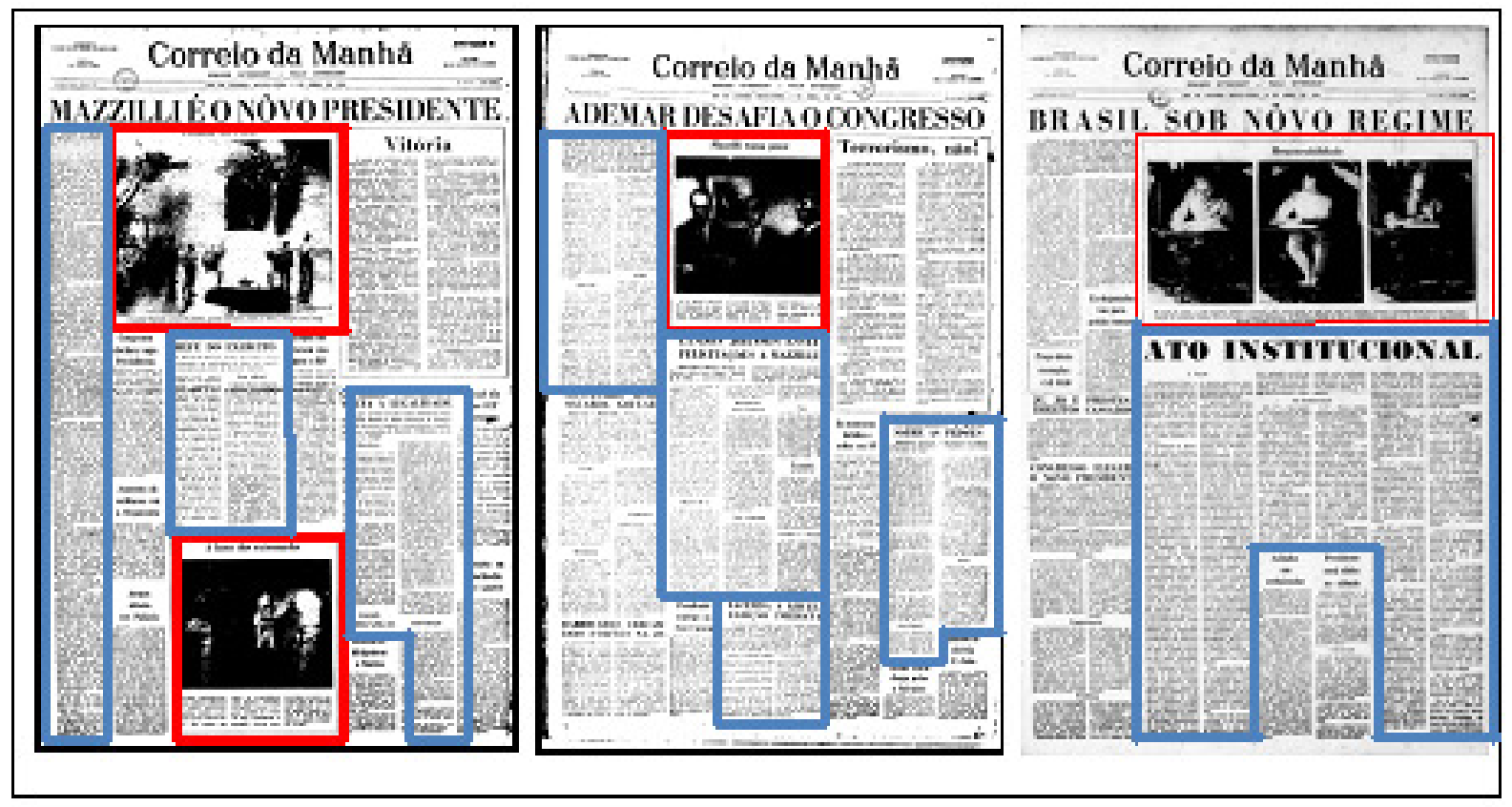

Figura 11 - Gêneros verbais e verbo-visuais no Correio da Manhã 


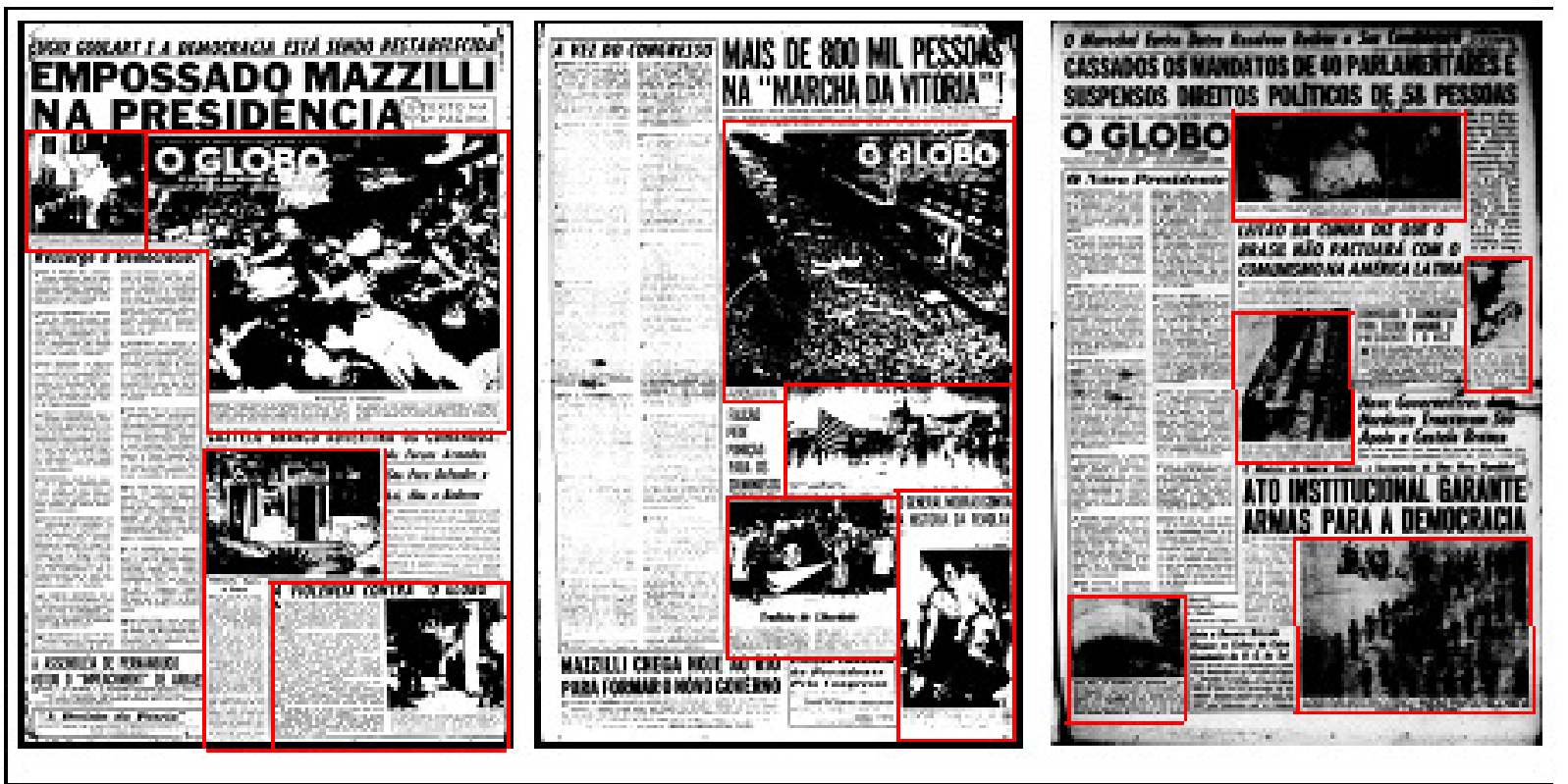

Figura 12 - Gêneros verbais e verbo-visuais n'O Globo

À primeira vista, a diferença entre os dois layouts é patente. De um lado, o Correio da Manhã constrói sua primeira página, recorrendo à linguagem verbal e dispondo suas matérias em oito colunas de maneira razoavelmente ordenada. De outro lado, $O$ Globo constrói sua primeira página com base na linguagem visual, fazendo forte uso de imagens fotográficas, variando o tamanho das fontes tipográficas dos títulos e as matérias, o que ressalta sua dimensão visual, e diagramando esses elementos fora das colunas, o que gera a sensação de leitura desordenada e tumultuosa.

Como essa diferença entre os dois layouts pode ser encarada também pelo viés financeiro da empresa jornalística e pelo contexto sócio-histórico de repressão aos meios de comunicação mesmo antes do $\mathrm{Golpe}^{45}$, é preciso reiterar aqui que o foco de nossa análise incide sobre os efeitos de sentido construídos pela

\footnotetext{
${ }^{45}$ Remetemos, novamente, à leitura do trabalho de René Armand Dreifuss (1981) consagrado à análise do processo de desestabilização do governo de João Goulart. Ao destacar a ação do complexo político-militar IPES/IBAD (Instituto de Pesquisas e Estudos Sociais/Instituto Brasileiro de Ação Democrática), afirma que, enquanto o IPES delineava as estratégias e se constituía como a inteligência da elite orgânica, o IBAD se responsabilizava pela ação propriamente dita, ou seja, os seus membros é que realizavam os ataques a figuras públicas por meio da mídia; que faziam pressão econômica sobre os empresários que não se encaixavam no perfil antigovernista; que repreendiam jornais que adotavam postura moderada contra o governo de João Goulart etc. Nesse processo, o jornal $O$ Globo e demais empresas pertencentes à mesma organização (alinhados ao regime) assistiram a um crescimento enorme durante o regime militar, ao passo que o Correio da Manhã (defensor inconteste de seus posicionamentos ideológicos, no caso, contrários ao regime ditatorial instaurado no País após a queda de João Goulart) foi sucumbindo até decretar sua falência dez anos após o Golpe de 64.
} 
composição das primeiras páginas, especialmente a inter-relação entre os gêneros discursivos. Assim, é preciso esmiuçar como essas diferenças se estabelecem.

Podemos ver, na Figura 11, que há, na primeira página do Correio da Manhã, o predomínio espacial dos gêneros verbais (editorial, notícia e nota comentário relatado) sobre os gêneros verbo-visuais (foto-legenda). Na Figura 12, podemos notar que, nas primeiras páginas d'O Globo, ocorre o inverso, pois os gêneros verbovisuais (foto-manchete e foto-legenda) ocupam mais espaço na página do que os gêneros verbais (editorial e chamadas para aprofundamento da notícia).

Quanto à função dos gêneros na página, notamos que, no Correio da Manhã, o gênero nota comentário relatado (vide Figura 11, elementos destacados em azul) cria, sob a forma do discurso direto (uma das formas do discurso citado), o simulacro da opinião das principais lideranças políticas do País a respeito dos fatos políticos ocorridos no Brasil naquela primeira quinzena de abril de 1964 (alhures manifestada por meio de nota oficial, manifesto, mensagem telegrafada, transcrição de pronunciamento emitido por rádio e televisão, Ato Institucional etc.), lançando, no contorno do discurso citado, as apreciações valorativas do jornal sobre a opinião ali relatada. Já, n'O Globo, o gênero que cumpre semelhante função de construção do real é a foto-legenda (vide Figura 12, elementos destacados em vermelho), pois a imagem fotográfica exerce o papel de mostrar os fatos, enquanto a legenda, o de expressar sua avaliação.

Os gêneros que compõem a primeira página de cada jornal e a maneira como ocupam o espaço da página, o layout, expõem os leitores a dois regimes diferentes de construção do real: de um lado, o Correio da Manhã constrói o simulacro de documentos e pronunciamentos oficiais; de outro lado, $O$ Globo engendra a representação dos fatos por meio de imagens fotográficas. Nessa inter-relação dos gêneros de discurso no hipergênero, entendemos que a opinião do jornal - emitida reconhecidamente por meio de um gênero específico, o editorial - permeia os sentidos produzidos pelos demais gêneros de discurso que compõem a primeira página, afigurando-se, portanto, como um forte elemento de homogeneização de sentidos dessa página, de modo a caracterizá-la não apenas como o rosto ou o espelho do jornal, mas também como uma página opinativa.

No entanto, há diferenças na construção dessas páginas de opinião, pois a primeira página do Correio da Manhã constrói uma cena enunciativa que convida subitamente seu leitor a refletir sobre os fatos midiatizados, enquanto a primeira 
página d'O Globo instala uma cena de enunciação própria à ideologia do flash (cf. Marcondes Filho, 2002).

Essas cenas enunciativas construídas a partir da composição da primeira página integram as estratégias discursivo-argumentativas de construção dos efeitos de realidade e de identificação entre jornal e leitor, constituindo, portanto, dois modos distintos de enunciar:

- A enunciação da primeira página do Correio da Manhã projeta um tipo de leitor mais afeito a uma leitura demorada, pois deve ler e acompanhar a construção dos argumentos apresentados pelo jornal, distinguindo a voz do jornal das vozes relatadas, as apreciações valorativas de um e de outro, as relações de causa e consequência etc.;

- A enunciação da primeira página d'O Globo projeta outro tipo de leitor, um leitor que tem preferência por uma leitura mais rápida, pois mais afeito à compreensão do mundo por meio da leitura das fotografias e da apreciação do jornal lançada nas legendas, em que se destaca a velocidade no consumo da informação.

Evidentemente, não estamos propondo ou sugerindo a prevalência da linguagem verbal sobre a linguagem visual ou vice-versa, todavia é preciso dizer que há diferentes graus de complexidade de leitura tanto nos textos visuais, quanto nos textos verbais. Por exemplo, a construção da leitura de um quadro como os de Salvador Dalí demanda recursos outros do que aqueles empregados para a leitura de uma fotografia jornalística, porque - para ser raso - esta, ao pretensamente mostrar o que seria a "realidade", oferece ao seu leitor um "mundo" que ele reconhece como sendo o seu mundo, ao passo que aquela tem a possibilidade de apresentar mundos que o leitor é capaz de reconhecer apenas no plano onírico, o que lhe exige a mobilização de estratégias de leitura mais sofisticadas.

Assim, considerando o contexto sócio-histórico e a situação de enunciação dos discursos dos jornais em questão, podemos dizer que a enunciação da primeira página do Correio da Manhã projeta a imagem de um leitor mais participativo, não do ponto de vista cognitivo, mas político, enquanto que a enunciação da primeira página d'O Globo projeta a imagem de um leitor menos participativo, ou seja, do potno de vista político, a imagem de um leitor espectador.

Assim, se, ao leitor do Correio da Manhã, compete acompanhar os argumentos e a linha de raciocínio do jornal, para o leitor d'O Globo o que fica é um 
grande material residual condensado numa forma de pensar orientada mais pela emoção do que pela razão, já que a página não convida o leitor a refletir sobre a informação, mas a se sensibilizar com ela.

Como já dissemos, anteriormente, a identidade visual do jornal participa do processo de construção do leitor do jornal, ou seja, de identificação entre jornal e leitor. E é interessante notar que as diferenças entre os layouts d'O Globo e do Correio da Manhã desempenham seus papéis na construção de diferentes leitores, logo de diferentes posicionamentos ideológicos perante o movimento político ocorrido no Brasil em abril de 1964.

Com base no contexto sócio-histórico desses discursos jornalísticos, podemos dizer que o discurso do Correio da Manhã projeta uma cena de enunciação em que jornal e leitor participam do processo político, de modo que valoriza positivamente sujeitos participativos e negativamente sujeitos não participativos, submissos ou alheios aos acontecimentos políticos, se considerarmos a grade axiológica dos discursos contrários à imposição das Forças Armadas. De outro lado, podemos depreender do discurso d'O Globo a projeção de uma cena enunciativa em que jornal e leitor assistem ao movimento político, valorizando positivamente sujeitos espectadores e negativamente sujeitos não espectadores, ou agitadores, considerando o ponto de vista da grade axiológica dos discursos ditos "revolucionários".

Neste momento, é preciso tecer algumas considerações parciais a respeito do que expusemos aqui sobre a relação entre hipergênero, cenografia, composição da primeira página do jornal, construção de identidade entre jornal e leitor, ethos e pathos.

O percurso teórico-analítico exposto até aqui pôde nos oferecer condições de mostrar como a composição do hipergênero "primeira página jornalística" mobiliza elementos enunciativos que servem a estratégias discursivo-argumentativas de captação do leitor, as quais passam, principalmente, pela construção da identidade discursiva do jornal e da identificação entre jornal e leitor. Trata-se, pois, de uma das preocupações da abordagem teórico-metodológica de nossa pesquisa, que compreende a argumentação como fato de discurso, aproximando, assim, os pressupostos da Análise do Discurso e da Teoria da Argumentação.

Quando nos propusemos a responder como a inter-relação dos gêneros jornalísticos no hipergênero "primeira página" contribui para a construção do efeito 
de real, estávamos pensando em ultrapassar uma visada, relativamente, óbvia acerca dos estudos discursivos sobre a relação entre o político e o jornalístico, pois procuramos mostrar como o layout da primeira página do jornal pode apresentar-se como um discurso gráfico-visual que contribui para a construção dos sentidos manifestados por meio da materialidade verbal, embora o foco de nossa análise não tenha, até este momento, recaído sobre o conteúdo verbal dos textos.

Outro aspecto suscitado durante a análise diz respeito à projeção das cenas enunciativas no hipergênero "primeira página". Ao tratar dos regimes de leitura, da captação do imaginário do leitor e de sua identificação com o jornal, tocamos, de fato, no problema da construção do leitor. Em outras palavras, dissemos que o leitor é um feixe de estratégias enunciativas e uma construção do próprio discurso jornalístico. Abordamos, pois, o leitor enquanto princípio discursivo, e não o leitor empírico.

Desse modo, ao conceber a primeira página não como um mero suporte, mas como um hipergênero discursivo, a análise pôde revelar como as cenas enunciativas projetadas pela primeira página captam o imaginário do leitor, conferindo papéis sociais aos parceiros da comunicação, jornal e leitor, orientando-lhes a posicionamentos discursivos perante a situação política do País num determinado momento histórico. Se a primeira página do Correio da Manhã requer um leitor que deve acompanhar o raciocínio argumentativo do jornal e das vozes relatadas no jornal, atribuindo-Ihe a imagem de um leitor participativo, e, se a primeira página d'O Globo destina-se a um leitor mais afeito a acompanhar os fatos políticos por meio de fotografias, conferindo-Ihe a imagem de um leitor espectador, vimos emergir, nesse contexto sócio-histórico de abril de 1964, duas identidades discursivas distintas e com posicionamentos discursivos bem definidos em relação ao movimento político daquele ano. 


\title{
4.2.2 Características dos gêneros das primeiras páginas dos jornais
}

Antes de proceder à análise dos discursos que emergem das primeiras páginas do Correio da Manhã e d'O Globo sobre o movimento político de 1964 , faremos uma breve apresentação dos gêneros jornalísticos que compõem a primeira página, ressaltando, isoladamente, suas características e finalidades.

Abordaremos as manchetes, os editoriais, as notas comentário relatado, as fotoslegendas, as fotos-manchetes, as fotos-legendas e as notícias, reagrupando esses gêneros conforme sua finalidade dentro da primeira página, a saber: (1) dar a manchete; (2) opinar; (3) documentar; (4) noticiar. De fato, essa fragmentação da primeira página trata-se de um recorte metodológico, o que não equivale dizer que os gêneros jornalísticos são opinativos ou informativos, por exemplo, mas sim que parecem opinativos, informativos etc. A esse respeito, Mosca (1990, p. 83) afirma o seguinte:

\begin{abstract}
Segundo uma teoria geral do discurso, os gêneros jornalísticos podem ser vistos como protocolos formais de enunciação. De fato, são as diferentes enunciações que tomam características certos discursos e estabelecem diversos modos de comunicação. Sob esta perspectiva, não há por que falar em gêneros informativos, interpretativos e opinativos. Acresce, ainda, o fato de que partimos do princípio de que o sentido é construído no texto, de forma imanente, de onde resulta o efeito de "verdade" produzido. [...]. É diferente dizer que os textos são informativos, opinativos e dizer que eles parecem informativos, opinativos etc.
\end{abstract}

O editorial é um gênero de discurso que se caracteriza por aquilo que Amossy $(2006,2007)$ chama de "intenção argumentativa", pois ele tem a finalidade explícita de levar o leitor a aceitar o ponto de vista oficialmente defendido pelo jornal. Já os demais gêneros que compõem as primeiras páginas do Correio da Manhã e d'O Globo possuem o que Amossy $(2006,2007)$ chama de "dimensão argumentativa", uma vez que não há a intenção explícita de argumentar, ou seja, o contrato midiático vela a argumentação sob a ilusão do ato de informar.

Do ponto de vista enunciativo, a cena enunciativa instaurada pelos gêneros discursivos "notícia", "nota", "nota comentário relatado", "foto-manchete" e "fotolegenda" projeta o leitor do jornal como um consumidor de informação. Considerando o que já expusemos acerca da teoria da argumentação e do discurso, é preciso dizer que esse discurso da informação e da prestação de serviços escamoteia, na essência, o ponto de vista da empresa jornalística e, consequentemente, de seus interesses políticos, comerciais e ideológicos. 
A "nota comentário relatado", a "foto-manchete" e a "foto-legenda" são gêneros discursivos que poderíamos chamar de gêneros jornalísticos documentais, uma vez que potencializam ao máximo o efeito de sentido de real, por criar no leitor a impressão de que ele está lendo os documentos oficiais (como é o caso do Correio da Manhã) ou vendo as imagens do evento relatado (como é recorrente n'O Globo), sendo que, do ponto de vista enunciativo, esse leitor está participando de um processo de enunciação de documentos e de imagens outrora e alhures enunciados.

Considerando sua função no interior da primeira página, é importante dizer que esses gêneros ditos documentais não somente criam o efeito de real, como também fortalecem a opinião explicitamente emitida pelo jornal em seu editorial, de modo que esses gêneros caracteristicamente desprovidos de intenção argumentativa (cf Amossy) trabalham em favor do gênero jornalístico que é prototipicamente marcado por essa intenção argumentativa.

A análise de gêneros verbo-visuais como a "foto-legenda" e a "foto-manchete" (que é a manchete visual) não deve se restringir ao exame da composição da imagem fotográfica, pois também participam da estrutura composicional desse gênero elementos como o título e a legenda, seja ela curta ou extensa. Assim, além de considerar a localização que a fotografia ocupa na página do jornal e os elementos próprios da composição da imagem fotográfica, o que também é preciso examinar nesses gêneros discursivos é a apreciação valorativa que o jornal lança na legenda da imagem sobre o acontecimento representado pela fotografia.

Passemos ao gênero "nota comentário relatado", o qual aparece somente no Correio da Manhã. Conforme dito anteriormente, esse gênero exerce, na primeira página do Correio da Manhã, a função de construir o simulacro das vozes das principais lideranças do país a respeito dos acontecimentos políticos em curso naquele momento, desempenhando função de relevo na composição da primeira página do Correio da Manhã, o que é reforçado em virtude da impressão de seus títulos com fonte em caixa alta, diferentemente das notícias, cujos títulos são compostos com fonte em caixa baixa.

Sobre as características do gênero "nota comentário relatado", Lisette Figueiredo (2003, p. 57), ao trabalhar com o gênero nota (e suas variantes), um corpus baseado no Jornal do Brasil, afirma que: 


\begin{abstract}
A nota comentário relatado pode ser considerada, funcionalmente, como um texto em que o repórter apresenta a posição de alguém diante de determinado fato, através da identificação do opinante, do relato do posicionamento ou suposição expressos por este opinante e do relato dos dados/argumentos que justificam o posicionamento ou suposição.
\end{abstract}

No corpus desta pesquisa, é possível notar que a "nota comentário relatado" é composta de uma breve introdução feita pelo jornalista (lead), seguida da reprodução de um documento, que pode ser um manifesto, uma proclamação, um pronunciamento etc. Do ponto de vista enunciativo, a publicação desse documento é a simulação da enunciação do discurso alheio, o que convoca as questões em torno das formas do discurso citado.

A noção de discurso citado corresponde às formas linguísticas de representação do discurso alheio, ou seja, a representação do discurso de um enunciador distinto daquele que é responsável pela enunciação do discurso. Nos termos de Bakhtin (2002, p. 144), "o discurso citado é o discurso no discurso, um discurso sobre o discurso". Consoante ao teórico russo, Authier-Revuz (1990, p. 2526) entende que o discurso citado - ou discurso relatado, em sua terminologia consiste em uma das formas da heterogeneidade mostrada do discurso, isto é, o conjunto de formas linguísticas que inscrevem o outro na sequência do discurso, representando de diferentes modos a negociação do sujeito com a heterogeneidade constitutiva do seu discurso. O discurso citado, porém, não corresponde ao discurso do outro em funcionamento, mas sim ao seu simulacro, que pode ser valorizado positivamente ou negativamente pelo discurso citante, de acordo com suas próprias categorias.

Assim, interessa-nos não apenas identificar o posicionamento das vozes que mais se fazem recorrentes no discurso jornalístico, mas também compreender o papel que esse jogo de vozes presente na primeira página desempenha na estratégia argumentativa de identificação entre jornal e leitor, de adesão aos posicionamentos do jornal, bem como esses fatores constituem o próprio discurso e a própria identidade discursiva do jornal.

Essas questões em torno do discurso citado valem igualmente para o gênero de discurso "notícia", no momento em que seu enunciador-jornalista delega a voz a um ator discursivo por meio das formas do discurso citado. Neste momento, é preciso sublinhar as características que distinguem a notícia de uma nota comentário relatado. 
Em primeiro lugar, a finalidade da nota comentário relatado na primeira página do jornal, como já foi dito, é a de simular a enunciação de um documento já enunciado alhures e outrora, ao passo que a finalidade da notícia numa página de jornal é, conforme Traquina (2008, p. 203), a de dar "existência pública aos acontecimentos ou à problemática".

Em segundo lugar, se a nota comentário relatado limita a voz do jornalista ao papel de introdutor do documento a ser publicado, a notícia exige do jornalista que ele conte uma estória, que pode ser sintetizada naquilo que o meio jornalístico convencionou chamar de lead e que consiste em responder às seis questões, a saber: o quê? quem? quando? onde? como? por quê? Vale destacar que Traquina (2008, p. 203), ao expor a teoria interacionista do jornalismo, concebe "a construção do acontecimento como notícia", compreendendo que "as notícias são construções, narrativas, 'estórias'”. Traquina (2008, p. 204) conclui que,

Para a teoria interacionista, o mundo social e político não é uma realidade predeterminada e "dura" que os jornalistas "refletem": a atividade jornalística é, para estes teóricos, bem mais complexa do que a ideologia jornalística sugere.

Nesse sentido, Bucci (2003, p. 9) afirma que:

Os fatos acontecem, no instante em que acontece, já como relatos. Ou, se quisermos, como elementos discursivos. Um fato ambiciona a condição de relato - pois só o relato dará a ele, mero fato, um sentido narrativo. Não há, portanto, fato jornalístico sem o relato jornalístico. O que pretendo dizer, enfim, é que o relato jornalístico ordena e por definição, constitui a realidade que ele mesmo representa como sendo a realidade feita de fatos.

Assim, tendo em vista que a notícia é, por excelência, o gênero jornalístico que constrói o acontecimento por meio do relato, a análise do discurso jornalístico deve considerar as seis questões do lead, observando quais discursos são suscitados pelas estórias relatadas no noticiário de capa dos jornais em tela.

Sobre isso, Traquina (2008, p. 199) faz uma reflexão muito importante sobre a relação entre o jornal e suas fontes:

Assim, tal como a teoria estruturalista, a teoria interacionista defende que as notícias são um aliado das instituições legitimadas. Devido à necessidade de impor ordem no espaço e no tempo, a 'estória' do jornalismo, no seu funcionamento diário, é descrita como sendo essencialmente 'estória' da interação de jornalistas e fontes oficiais. As fontes provêm sobretudo da estrutura do poder estabelecido e, por isso, as notícias tendem a apoiar 0 status quo [grifos nossos]. 


\subsection{Análise das primeiras páginas das edições de 2 de abril}

As edições de 2 de abril de 1964 midiatizam o acontecimento em torno da deposição de João Goulart, a posse do presidente interino Raniere Mazzilli e as primeiras ações da chamada "Revolução" para "restabelecer a ordem e livrar o país da ameaça comunista". Primeiramente, identificamos, no Quadro 8, os títulos que compõem a primeira página dos jornais, agrupando-os conforme suas finalidades:

Quadro 8 - Títulos das capas do Correio da Manhã e d'O Globo de 02.04.1964

\begin{tabular}{|c|c|c|c|c|}
\hline \multirow{2}{*}{$\begin{array}{l}\text { FINA } \\
\text { LIDA } \\
\text { DE }\end{array}$} & \multicolumn{2}{|c|}{ Correio da Manhã } & \multicolumn{2}{|r|}{ O Globo } \\
\hline & Gênero & Título & Gênero & Título \\
\hline \multirow{3}{*}{ 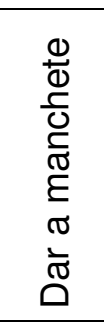 } & Manchete & $\begin{array}{l}\text { MAZZILLI É O NÔVO } \\
\text { PRESIDENTE }\end{array}$ & $\begin{array}{l}\text { Chapéu } \\
\text { da página }\end{array}$ & $\begin{array}{c}\text { FUGIU GOULART E A } \\
\text { DEMOCRACIA ESTÁ SENDO } \\
\text { RESTABELECIDA }\end{array}$ \\
\hline & & & Manchete & $\begin{array}{c}\text { EMPOSSADO MAZZILLI NA } \\
\text { PRESIDÊNCIA (texto na } 6{ }^{a} \text { pág) }\end{array}$ \\
\hline & & & \begin{tabular}{|c|} 
Foto- \\
manchete
\end{tabular} & Coragem e emoção \\
\hline $\begin{array}{l}\overline{\frac{\pi}{0}} \\
\frac{\overline{\bar{O}}}{0}\end{array}$ & Editorial & Vitória & Editorial & Ressurge a democracia! \\
\hline \multirow{5}{*}{ 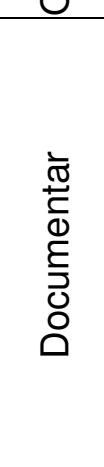 } & Foto-legenda & Tomada do forte & $\begin{array}{c}\text { Foto- } \\
\text { legenda }\end{array}$ & Sem título \\
\hline & Foto-legenda & A hora dos extremados & & \\
\hline & $\begin{array}{l}\text { Nota comen- } \\
\text { tário relatado }\end{array}$ & (contígua à manchete) & & \\
\hline & $\begin{array}{l}\text { Nota comen- } \\
\text { tário relatado }\end{array}$ & $\begin{array}{l}\text { ARTUR COSTA É O NÔVO } \\
\text { CHEFE DO EXÉRCITO }\end{array}$ & & \\
\hline & $\begin{array}{l}\text { Nota comen- } \\
\text { tário relatado }\end{array}$ & $\begin{array}{l}\text { GENERAIS PROMETEM } \\
\text { VOLTA À LEGALIDADE }\end{array}$ & & \\
\hline \multirow{7}{*}{$\frac{. \overline{\frac{\pi}{0}}}{\frac{.}{\bar{O}}}$} & Notícia & $\begin{array}{c}\text { Congresso declara vaga } \\
\text { Presidência }\end{array}$ & $\begin{array}{l}\text { Notícia } \\
\text { com } \\
\text { chamada }\end{array}$ & $\begin{array}{c}\text { CASTELO BRANCO } \\
\text { ADVERTIRA OS COMANDOS: } \\
\text { As Fôrças Armadas São Para } \\
\text { Defender a Lei, Não a Baderna }\end{array}$ \\
\hline & Notícia & $\begin{array}{c}\text { Aumento de militares vai a } \\
\text { Orçamento }\end{array}$ & $\begin{array}{l}\text { Notícia } \\
\text { com foto }\end{array}$ & $\begin{array}{c}\text { A VIOLÊNCIA CONTRA "O } \\
\text { GLOBO" }\end{array}$ \\
\hline & Notícia & Arraes sitiado em Palácio & $\begin{array}{l}\text { Notícia } \\
\text { com foto }\end{array}$ & Silêncio após a fuga \\
\hline & Notícia & $\begin{array}{l}\text { Tropas do Paraná vão para } \\
\text { o Rio Grande do Sul }\end{array}$ & Notícia & $\begin{array}{c}\text { A ASSEMBLÉIA DE } \\
\text { PERNAMBUCO VOTOU O } \\
\text { “IMPEACHMENT” DE ARRAES }\end{array}$ \\
\hline & Notícia & $\begin{array}{c}\text { Belonaves dirigem-se a } \\
\text { Santos }\end{array}$ & Nota & “A Decisão da Pátria!" \\
\hline & Notícia & Kruel diz que CGT terminou & & \\
\hline & Notícia & $\begin{array}{c}\text { Tiroteio na Cinelândia fere } \\
\text { quatro }\end{array}$ & & \\
\hline
\end{tabular}




\subsubsection{As manchetes}

As manchetes da edição de 2 de abril de 1964 do Correio da Manhã e d'O Globo destacam no alto da primeira página a posse do presidente interino, indiciando ser esse o acontecimento mais importante das edições de ambos os jornais. Todavia cada jornal constrói tal acontecimento de maneira distinta. O Correio da Manhã divulga, em uma manchete simples, o nome do novo presidente ("Mazzilli é o nôvo presidente"), cumprindo, assim, o que o jornalismo entende como sendo sua função, isto é, dar a informação de maneira objetiva. Por sua vez, O Globo publica uma manchete com um chapéu de página, em que os dois enunciados funcionam como título e subtítulo da página ("Fugiu Goulart e a democracia está sendo restabelecida" e "Empossado Mazzilli na presidência").

A manchete do Correio da Manhã não só divulga o nome do novo presidente, como se noticiasse o nome do novo reforço de um time de futebol, mas quer dizer que, após a "desordem" gerada pelo governo João Goulart, a situação política do país está se normalizando. Observando a manchete e o chapéu da primeira página d'O Globo, podemos notar que, em duas ocasiões, os atores não são agentes das ações, pois o jornal não informa quem está restabelecendo a democracia nem quem deu posse a Mazzilli. Embora a informação fique reticente na manchete e no chapéu, os demais gêneros da primeira página evidenciam que os responsáveis pelo restabelecimento da ordem são as Forças Armadas.

Do chapéu da página d'O Globo, constrói-se uma cenografia que apresenta a ação golpista como se fosse uma ação policial, pois a queda de Goulart é construída como se fosse um ato de fuga voluntário do presidente, como se ele estivesse em débito com o país e, encurralado, precisasse abandonar o país em "debandada".

Do ponto de vista da captação do imaginário do leitor, essa cenografia contribui para a construção de um sentimento de satisfação e de alívio, pois "o criminoso" que estava em "débito" com "o povo" fugiu dos "heróis". Temos aqui os primeiros elementos para a construção do pathos da primeira página d'O Globo. Constrói-se a imagem de João Goulart como aquela de criminosos em fuga, o que revela um tom discursivo bem distinto daquele observado no Correio da Manhã. $\mathrm{O}$ tom objetivo da manchete do Correio da Manhã coaduna-se com o layout sóbrio de sua primeira página, o que contrasta com o tom sensacionalista e o layout desalinhado d'O Globo. 


\subsubsection{Os editoriais}

Em 2 de abril de 1964, o Correio da Manhã e O Globo estampam, respectivamente, em suas primeiras páginas os editoriais intitulados: "Vitória" e "Ressurge a Democracia!". De modo geral, os dois jornais se mostram favoráveis à deposição do presidente João Goulart, o que poderia caracterizar posicionamentos ideológicos concordantes e, portanto, discursos inscritos em uma mesma formação discursiva. Todavia, o clima de euforia instaurado pela queda do presidente João Goulart, materializado também pelas manchetes "Vitória" e "Ressurge a Democracia!", escamoteia as seguintes questões:

- Quem venceu e quem perdeu?

- Qual foi o objeto da disputa e qual foi o prêmio? Quem venceu ganhou o quê?

- Quem fez a democracia ressurgir e quem a havia escondido?

- Quais são as expectativas após a vitória e o ressurgimento da democracia?

Parece-nos que essas questões podem nos revelar qual é o posicionamento ideológico e a formação discursiva de cada jornal, e não a sua posição contrária ou favorável à queda do presidente João Goulart.

O Correio da Manhã contrapõe "aqueles que sempre ameaçaram as instituições" e "aqueles que sempre as defenderam", incluindo-se nesta última categoria. Atribui a "vitória" não "à direita", mas "aos que condenam as radicalizações, aos que procuram evitar que seja interrompido o processo democrático, aos que querem a legalidade, a disciplina, o cumprimento da lei" (CORREIO DA MANHÃ, 1964a). No discurso do Correio da Manhã, "vitória" significa, então, a conquista de valores como "a democracia", "a legalidade”, "a disciplina", "a lei". Para o Correio da Manhã, "esta vitória é da democracia e da nação brasileira". Trata-se de um discurso que reproduz a ideologia da nação brasileira como vencedora.

De outro lado, O Globo constrói um discurso em as "Forças Armadas" têm papel fundamental no processo de "restauração da democracia brasileira", ao passo que o "povo brasileiro" cumpre não o papel de sujeito agente de transformação (como no Correio da Manhã), mas o de vítima socorrida: 
GRAÇAS À DECISÃO e ao heroísmo das Fôrças Armadas, que obedientes a seus chefes demonstraram a falta de visão dos que tentavam destruir a hierarquia e a disciplina, o Brasil livrou-se do Governo irresponsável [...] (O GLOBO, 1964a).

ÊSTE NÃO FOI um movimento partidário. Dêle participaram todos os setores conscientes da vida política brasileira, pois a ninguém escapava o significado das manobras presidenciais. Aliaram-se os mais ilustres líderes políticos, os mais respeitados Governadores, com o mesmo intuito redentor que animou as Fôrças Armadas (O GLOBO, 1964a).

MAIS UMA VEZ, o povo brasileiro foi socorrido pela Providência Divina, que Ihe permitiu superar a grave crise, sem maiores sofrimentos e luto [...] ( $O$ GLOBO, 1964a).

Enquanto o Correio da Manhã censurava o comportamento do presidente João Goulart por meio de críticas à sua administração, o editorial d'O Globo repreende o presidente, atribuindo-Ihe a imagem de comunista:

SALVOS DA COMUNIZAÇÃO que celeremente se preparava, os brasileiros devem agradecer aos bravos militares, que os protegeram de seus inimigos [...] (O GLOBO, 1964a).

Constrói-se não só um acontecimento discursivo, mas também seus atores. E a maneira como tal acontecimento e seus atores são reproduzidos nos permite depreender o posicionamento ideológico de cada jornal. No discurso d'O Globo, "o ressurgimento da democracia" significa a conquista de valores como "a democracia", "a lei", "a ordem". Não parece muito diferente do que o Correio da Manhã entende por "vitória"; todavia, vê-se que este já demonstra preocupação com quem iria ocupar o vácuo deixado pela deposição de João Goulart, ao contrário daquele, que faz acreditar que o "Congresso Nacional guiará a nação ao seu futuro":

O afastamento do govêrno do sr. João Goulart não justifica de modo algum um regime de exceção. Não justifica violências nem crimes cometidos contra a liberdade individual e coletiva (CORREIO DA MANHÃ, 1964a).

Não admitimos - e o fazemos com autoridade e isenção - que para se restaurar a disciplina se restabeleça 0 arbítrio de quem quer que seja (CORREIO DA MANHÃ, 1964a).

AGORA O CONGRESSO dará o remédio constitucional à situação existente, para que o País continue sua marcha em direção ao seu grande destino [...] (O GLOBO, 1964a)

Note-se, nesses enunciados, que a palavra "marcha" não pode de forma alguma ser lida como um signo neutro (como se isso fosse possível), pois ela se 
inscreve em uma cadeia interdiscursiva que atualiza o acontecimento da "Marcha da Família com Deus pela Liberdade" e remete à marcha dos soldados, valorizando as Forças Armadas.

Fiorin (1988, p. 34) mostra que o grupo golpista consegue produzir um discurso em que "Goulart" engana o "povo" ao se alinhar "o movimento comunista internacional", gerando a insatisfação e a decepção do "povo", que passa a confiar nas "Forças Armadas". Fiorin (1988, p. 52-54) mostra ainda que o dito discurso "revolucionário" promete tirar o Brasil do "caos" (desordem, desgoverno, inflação, subversão, anarquia etc.) e estabelecer a "ordem" (disciplina, desenvolvimento, nãoinflação, respeito à hierarquia), concluindo que "restauração da ordem não é reforma, é a negação do reformismo, que é apresentado como ‘subversão'” (p. 63).

Esta análise dos editoriais das edições de 2 de abril do Correio da Manhã e d'O Globo já nos permite apontar a quais formações ideológicas esses dois jornais estão filiados e, a partir daí, depreender suas formações discursivas. Naquele primeiro momento, não havia ainda na grande imprensa, sobretudo nos dois jornais sob análise, uma oposição ao putsch, porém é possível observar como esses dois jornais não reproduzem o mesmo discurso sobre o acontecimento da deposição de João Goulart.

Entendemos, assim, que os discursos que emergem dos editoriais de 2 de abril de 1964 do Correio da Manhã e d'O Globo, embora favoráveis à queda do presidente, estão inscritos em formações discursivas distintas, reforçando o que já mostramos no exame da constituição do hipergênero "primeira página" e das manchetes desses jornais. 


\subsubsection{As notas comentário relatado}

Na primeira página do Correio da Manhã, a nota comentário relatado contígua à manchete (vide Quadro 2, Texto 2) reproduz uma proclamação deixada ao povo pelo presidente deposto João Goulart. É possível observar, nessa página, a contradição que há entre o título (a manchete) e a matéria em si (nota comentário relatado), pois, se de um lado, o título informa o nome do novo presidente, de outro lado, o corpo do texto dedica maior parte de seu espaço à publicação, na íntegra, de um discurso do presidente deposto, ao invés de informar detalhes da posse do novo presidente, como presumido pela manchete.

Por meio da publicação dessa proclamação de João Goulart, irrompe da primeira página do Correio da Manhã um discurso controverso ao discurso dito "revolucionário", com os quais esse jornal dialoga e negocia a construção de sua própria identidade discursiva. Nos enunciados de (1) a (8), destacamos os valores e os atores axiologizados positiva e negativamente pelo discurso de João Goulart:

(1) [...] fôrças reacionárias desencadeiam mais uma vez o golpe contra as instituições democráticas e contra a libertação econômica da Pátria [...].

(2) [...] tive que adotar [...] medidas inadiáveis de proteção à sua espoliada economia, arrastei a fúria insensata e odienta dos impatrióticos interesses contrariados [...].

(3) Determinei os princípios cristãos de justiça social, determinou o recrudescimento de ódios e paixões.

(4) [...] assisti mancomunar-se novamente contra mim uma ação insidiosa dos que sempre se locupletaram com a miséria do nosso povo.

(5) Levantou-se a grita da incompreensão e do egoísmo, do capitalismo intolerante, desumano e anticristão.

(6) [...] minha fidelidade ao ideário de Vargas e aos compromissos do meu passado, em lutas nacionalistas [...].

(7) Exploraram o sentimento religioso, como se meu governo não fosse daquele que na história da República mais se empenharam em cercar de prestígio, de conciliação e de respeito, os dignitários do Episcopado, do Clero da igreja Católica e dos demais credos religiosos.

(8) Mistificam-se com a supervalorização do perigo comunista, como se não fôssemos uma democracia plantada irremovívelmente no coração de nossa gente. 
No enunciado em (1), destaca-se uma referenciação discursiva que é, praticamente, silenciada na grande imprensa, pois o enunciador Correio da Manhã instala em seu enunciado uma instância subjetiva "João Goulart" que referencia os ditos "revolucionários" como "forças reacionárias" e a chamada "revolução" como "golpe".

No enunciado em (5), diferentemente dos discursos ditos "revolucionários", a axiologização "capitalismo" versus "comunismo" aparece de forma menos polarizada no discurso nacional-reformista de João Goulart, pois, ao atribuir valores ao capitalismo, não o faz de maneira generalizada - tal como fazem os adversários do comunismo - mas de forma específica, quando diz "o capitalismo intolerante, desumano e anticristão", estabelecendo o pressuposto de que existe o capitalismo tolerante, humano e cristão.

Por meio do enunciado "o capitalismo intolerante, desumano e anticristão", a representação do discurso de João Goulart feita pelo diário Correio da Manhã atribui essas qualificações valorizadas negativamente ao anti-sujeito do discurso nacionalreformista de Goulart, ao passo que associa, implicitamente, as qualificações valorizadas positivamente do enunciado pressuposto "capitalismo tolerante, humano e cristão" ao sujeito desse discurso nacional-reformista, que é o próprio João Goulart. Esse enunciado participa da estratégia de refutação ao discurso que atribui a João Goulart a imagem de comunista, o que é reforçado no enunciado em (8) ao mostrar o distanciamento do presidente deposto perante o comunismo e ao reiterar a solidez dos ideais democráticos.

Nessa proclamação publicada pelo Correio da Manhã, João Goulart refuta também a imagem de não patriota, recuperando o ideário nacionista de Vargas, ao mesmo tempo em que associa o "impatriotismo" aos seus adversários:

(1) [...] fôrças reacionárias desencadeiam mais uma vez o golpe contra as instituições democráticas e contra a libertação econômica da Pátria [...].

(2) [...] a fúria insensata e odienta dos impatrióticos interesses contrariados $[\ldots]$.

(6) [...] minha fidelidade ao ideário de Vargas e aos compromissos do meu passado, em lutas nacionalistas [...].

Nesse discurso de João Goulart, surge também o discurso da "justiça social aliada à fé cristã", que é o discurso da tendência progressista da Igreja Católica - 
chamada pelos ditos "revolucionários" de "subversiva" ou "vermelha", o que nos faz lembrar da expressão "padre vermelho". O discurso dessa tendência reformula o discurso do "nosso reino não pertence a este mundo" e "somente encontraremos a paz quando estivermos ao lado de Deus no Paraíso", dizendo que "o reino de Deus é aqui na Terra também”. Estabelece-se, portanto, uma relação polêmica no campo do discurso religioso, em que o discurso cristão que sustenta o discurso político da classe dominante é refutado pelo discurso cristão que sustenta o discurso político contra a classe dominante, o qual aparece no discurso nacional-reformista de João Goulart sob a forma de "determinei os princípios cristãos de justiça social" e "o capitalismo intolerante, desumano e anticristão".

Na edição de 2 de abril de 1964, o Correio da Manhã recorre mais duas vezes ao gênero "nota comentário relatado", com os títulos: "Artur Costa é o nôvo chefe do Exército" e "Generais prometem volta à legalidade". Nessas duas ocorrências, o jornal simula uma enunciação alhures do alto-comando do Exército, publicando uma nota oficial assinada pela "chefia do Estado-Maior do Exército, o general de Exército Humberto de Alencar Castelo Branco" (vide Quadro 2, Texto 7) e um manifesto assinado pelos generais "Arthur da Costa e Silva, Humberto Alencar Castelo Branco e Décio Paleiro de Escobar, membros do Alto Comando" (vide Quadro 2, Texto 11).

Nessas duas notas comentário relatado, O Correio da Manhã, diferentemente do que faz na primeira nota comentário relatado, na qual simula a voz do presidente deposto João Goulart, presentifica enunciações alhures das Forças Armadas, dando-lhes mais destaque do que a Mazzilli, que, apesar de ocupar a Presidência naqueles dias, é construído como personagem secundário nesse cenário de tomada do poder.

Dessa maneira, o jornal cria um cenário em que se despontam as figuras dos generais do alto-comando do Exército e personifica, assim, as Forças Armadas na figura desses generais, sobretudo na do General de Exército Artur da Costa e Silva, atribuindo-Ihe a imagem de herói, ao passo que constrói a imagem de seus antiheróis, concretizando-os em personalidades políticas ligadas ao governo João Goulart. Por meio da enunciação dessas duas notas comentário relatado, o Correio da Manhã reproduz o discurso de enaltecimento das Forças Armadas e da difamação de João Goulart e seus aliados.

Na nota comentário relatado "ARTUR COSTA É O NÔVO CHEFE DO EXÉRCITO" (Quadro 2, Texto 7), podemos notar como ocorre esse jogo de imagens entre heróis 
e anti-heróis, em que o jornal simula a enunciação de uma nota oficial, na qual o General Costa e Silva se diz responsável por:

[...] restabelecer a coesão e a eficiência operativa das grandes unidades do Exército, com o objetivo primordial de assegurar a ordem no País e sobretudo de eliminar a subversão dirigida no Rio Grande do Sul, por Leonel Brizola (CORREIO DA MANHÃ, 1964a).

A simulação da enunciação da nota oficial projeta duas imagens antagônicas: de um lado, há um "governante subversivo", ou seja, que vai contra a "ordem no País", concretizado na figura do governador do Rio Grande do Sul, Leonel Brizola; de outro lado, há um novo chefe de Exército, que promete corrigir a inoperância do Exército e eliminar a subversão, isto é, solucionar o que, para eles, são os problemas ocasionados pelo governo recém-deposto.

$\mathrm{Na}$ nota comentário relatado "GENERAIS PROMETEM VOLTA À LEGALIDADE" (Quadro 2, Texto 11), o jornal cria o simulacro da enunciação do manifesto das Forças Armadas, atribuindo, desta vez, a imagem do anti-herói ao próprio presidente deposto João Goulart, atualizando a sua imagem, previamente construída, de membro associado ao comunismo internacional:

Em ostensivo conluio com notórios elementos comunistas, sob cujo domínio parece até mesmo encontrar-se, o presidente João Goulart vem-se colocando na mais flagrante ilegalidade, através de sucessivos atentados à prática justa do regime democrático (CORREIO DA MANHÃ, 1964a).

O discurso do jornal constrói um efeito de sentido de real em que os atores que protagonizam a cena política pertencem aos quadros do Exército, suplantando a figura do presidente deposto e do então presidente recém-empossado em nome de valores como "a democracia", "a legalidade", "a disciplina" e "a lei".

É interessante notar que, se, no editorial, a vitória pertence à nação brasileira e não às Forças Armadas e se, da nota comentário relatado contígua à manchete, irrompe o discurso quase proibido do reformismo de João Goulart, essas duas notas comentário relatado revelam uma aparente contradição no discurso do Correio da Manhã, ao enaltecer as Forças Armadas.

Essa aparente contradição criada pelas notas comentário relatado do Correio da Manhã emerge da conflituosa negociação entre sua identidade discursiva e sua alteridade no sentido de o jornal apresentar como um posicionamento que tenta escapar da polarização axiológica (1) imposta pela reorganização das forças sociais 
brasileiras em dois grupos distintos, governistas e antigovernistas, que, após a derrubada de João Goulart, passaram a se denominar como "antigolpistas" e "revolucionários", respectivamente, e (2) apoiada na axiologização entre os valores ditos "capitalistas" e "comunistas" atualizada pela polêmica discursiva instaurada em torno da Guerra Fria.

A esse respeito, ao discorrer sobre a heterogeneidade discursiva, em nossos Pressupostos Teóricos, salientamos que as formas da heterogeneidade nos permitem desvelar a presença do Outro no fio discursivo e que a maneira como o discurso negocia com sua alteridade revela seu posicionamento, corrobora a construção de sua identidade e participa da caracterização de seu ethos.

Assim, se o editorial do Correio da Manhã atribui a "vitória" à nação brasileira e não às Forças Armadas, o conjunto de notas comentário relatado, por sua vez, reproduz os discursos (1) da denúncia do golpe de estado sofrido pela democracia e aplicado pelas forças reacionárias associadas ao capitalismo e (2) do anúncio da revolução conduzida pelas Forças Armadas contra a ameça comunista de João Goulart e seus aliados.

O que parece ser uma contradição é a manifestação de um dos valores do discurso jornalístico, que é a busca pela objetividade e pela imparcialidade. Ao contrário d'O Globo, que se refere a João Goulart como fugitivo, o enunciador Correio da Manhã delega voz a João Goulart, para que o discurso de presidente deposto irrompa na primeira página de um jornal de grande circulação nacional, contrariando a tendência geral de silenciamento do discurso de João Goulart e superexposição e supervalorização do discurso dos generais "revolucionários". Esse é um ponto a ser considerado. No entanto, é preciso ressaltar, ainda, que, se do ponto de vista argumentativo, essa delegação de voz a João Goulart serve a uma estratégia de refutação, uma vez que o discurso de João Goulart é rechaçado pelo Correio da Manhã em seu editorial, o que tem efeitos em matéria de ethos, do ponto de vista da interdiscursividade, essa negociação entre o discurso citante do Correio da Manhã e o discurso citado de João Goulart revela um sujeito discursivo cindido entre os discursos localizados nos polos axiológicos da polêmica em torno do movimento político de 1964, o que também tem efeitos na construção do ethos.

Assim, poderíamos dizer que o ethos do jornalismo imparcial e objetivo esperado pela cena englobante projetada pelo discurso jornalístico é confirmado pelo discurso do Correio da Manhã. Todavia, o acontecimento em torno do 
movimento político de 1964 extrapola qualquer expectativa de construção de comportamento e de posicionamento devido à sua relevância na alteração do cenário político. Afinal, vale lembrar que na época chegou-se a cogitar em guerra civil caso as forças de João Goulart resolvessem resistir ao golpe. Esses são elementos que nos fazem reavaliar essa qualidade de ethos depreendida, pois, diante de toda pressão exercida pelos grupos de operação do complexo IPES/IBAD sobre os meios de comunicação, não é possível dizer que o jornal foi imparcial ao publicar pronunciamentos de ambos os lados envolvidos nessa polêmica, mas sim que o discurso do jornal revela suas inquietações e incertezas a respeito da natureza desse movimento político que se autodenominou como "revolução". 


\subsubsection{Os gêneros verbo-visuais: a foto-manchete e a foto-legenda}

Na primeira página da edição de 2 de abril de 1964 do Correio da Manhã, a foto-manchete intitulada "Tomada do Forte" localiza-se na metade superior da primeira página, para destacar uma das ações militares que simbolizaram o fim do governo João Goulart. O episódio retratado consiste na tomada do Forte de Copacabana, onde houve confronto entre as tropas leais ao presidente deposto e o destacamento comandado pelo Coronel Montanha. Tratava-se, nessa ocasião, de um dos últimos símbolos do esboço de uma resistência de João Goulart ao golpe que tomara.

Do ponto de vista da midiatização do acontecimento, podemos perceber que a imagem fotográfica não revela uma cena violenta. Na parte inferior da imagem, um carro separa um grupo pequeno de dois homens de outro grupo com seis homens, sendo que alguns estão de braços cruzados, outros com os braços abaixados e ninguém de arma em punho. Na parte superior da imagem, um destacamento de soldados (segundo a legenda são vinte soldados) perfilados e organizados em três fileiras, com seus fuzis abaixados. Evidentemente, trata-se de uma ação militar, com exibição de poder, todavia a imagem fotográfica não apresenta uma efetiva ação de combate entre forças contrárias, isto é, não flagra o tiroteio ocorrido no Forte de Copacabana, afastando-se assim de um foto-jornalismo de linha sensacionalista.

$\mathrm{Na}$ legenda, podemos notar como o verbal corrobora o visual, pois o jornal descreve uma situação em que os militares dominam a situação contra João Goulart. A ação expressa pela legenda é "dominar", mas não "eliminar" como pudemos ver no discurso citado do General Costa e Silva simulado na nota comentário relatado examinada anteriormente.

$\mathrm{Na}$ foto-legenda "A hora dos extremados", o discurso do jornal constrói a denúncia e a condenação de um ato de vandalismo contra o jornal Última Hora praticado por um grupo antijanguista formado de estudantes e populares. A imagem mostra homens apagando o fogo, enquanto a legenda resume os fatos ocorridos.

$O$ jogo de sentido que emerge desses dois gêneros verbo-visuais no espaço da primeira página do Correio da Manhã é que, ao mesmo tempo em que se constrói uma imagem arranhada das forças contrárias a João Goulart, constrói-se uma imagem amplamente favorável às Forças Armadas, já que o jornal atribui ao Exército uma ação moderada, conduzida sem violência e com domínio da situação. 
Apresenta-se, portanto, de um lado, a marginalidade de grupos antijanguistas; de outro lado, a legalidade da ação do Exército.

O Globo, por sua vez, cria o efeito de "documentação dos fatos", unicamente, por meio do discurso verbo-visual, recorrendo aos gêneros foto-legenda e fotomanchete. Diferentemente do Correio da Manhã, O Globo não pretende expor ao leitor os argumentos das principais lideranças ditas revolucionárias à população, mas sim captar sua adesão por meio da ideologia ou retórica do flash (cf. Marcondes Filho, 2002).

Todavia, é interessante notar quem são os heróis construídos pelo jornal $O$ Globo. Na foto-manchete "Coragem e emoção" (vide Quadro 3, Texto 3), o jornal exalta a coragem do governador da Guanabara, Carlos Lacerda, um dos principais opositores ao governo João Goulart, e trata o episódio da chegada dos tanques de guerra com apelo emocional e sensacionalista. $\mathrm{Na}$ foto-legenda sem título (vide Quadro 3, Texto 4), o jornal, de certa forma, justifica o incêndio na sede da UNE em nome da revolta "do povo".

Enquanto o discurso do Correio da Manhã chama os responsáveis pelo incêndio do jornal Última Hora de "estudantes e populares", o discurso d'O Globo chama os responsáveis pelo incêndio da UNE de "povo". Nota-se que, de um lado, o Correio da Manhã repreende os criminosos e, de outro lado, O Globo justifica a ação atribuindo o sentimento de revolta contra "agitadores e falsos estudantes"; que o Correio da Manhã defende outro jornal, ao passo que $O$ Globo ataca a UNE.

É importante dizer que a análise integral da página do jornal permite ao analista observar a ressignificação dos sentidos construídos em cada gênero da página, pois, se os editoriais mostram dois jornais favoráveis à deposição de João Goulart, ou seja, jornais com posicionamentos semelhantes, as notas comentário relatado, a foto-manchete e a foto-legenda deixam entrever que esses jornais sustentam discursos bem distintos, uma vez que eles são construídos com base em valores distintos. 


\subsubsection{As notícias}

Observaremos, nesta subseção, como o noticiário apresentado nas primeiras páginas de ambos os jornais constroem, discursivamente, os acontecimentos que viriam a ser a ordem do dia naquele momento, focalizando especialmente como a notícia constrói seus atores e lhes atribui imagens favoráveis ou desfavoráveis dentro da polêmica em torno dos fatos políticos discursivizados por cada jornal.

Do Quadro 2, destacamos os seguintes títulos das notícias do Correio da Manhã:

- "Congresso declara vaga Presidência" (Texto 4);

- "Aumento de militares vai a Orçamento" (Texto 5);

- “Arraes sitiado em Palácio" (Texto 6);

- "Tropas do Paraná vão para o RS" (Texto 8);

- "Belonaves dirigem-se a Santos" (Texto 12)

- "Kruel diz que CGT terminou" (Texto 13);

- "Tiroteio na Cinelândia fere quatro" (Texto 14).

E, do Quadro 3, podemos recuperar os títulos das notícias d'O Globo:

- "Castelo Branco advertira os comandos: As Fôrças Armadas São Para Defender a Lei, Não a Baderna" (Texto 6);

- "A violência contra O Globo" (Texto 7);

- "Silêncio após fuga" (Texto 8);

- "A Assembléia de Pernambuco votou o 'impeachment' de Arraes” (Texto 9).

O que se deve ressaltar é que todas as notícias, assim como todos os demais gêneros integrantes das primeiras páginas dos dois jornais, voltam-se, sem exceção, para os acontecimentos políticos em curso naquele abril de 1964. Esse é um indício da dimensão que tais fatos representaram naquele momento. O noticiário é a confirmação do novo cenário político nacional: a transição traumática e violenta entre o governo deposto e o novo regime em definição.

Outro ponto é que, com exceção aos textos "Tiroteio na Cinelândia fere quatro" (do Correio da Manhã) e "A violência contra O Globo" (d'O Globo), os títulos das notícias são construídos de maneira que o leitor perceba que apenas as forças contrárias ao governo João Goulart é que estão no comando das ações, tomando providências para restabelecer a ordem. Enfim, o panorama geral dado pelo conjunto das notícias, bem como pelos demais gêneros da primeira página, é de domínio das Forças Armadas sobre o governo João Goulart. 


\subsubsection{Os pathé e os ethé das primeiras páginas}

No editorial de 2 de abril de 1964, o enunciador Correio da Manhã instala no enunciado o sujeito "Sr. João Goulart" que contrai uma relação tumultuada com "a Nação" por causa "de sua nefasta administração que estabelecia, em todos os setores, o tumulto e a desordem" (CORREIO DA MANHÃ, 1964a). Do ponto de vista passional, o editorial constrói a imagem de uma nação que convive com a falta de liberdade e a falta de confiança no presidente:

A queda do Sr. João Goulart se explica pela ameaça que pesava sôbre a nação de perder a sua liberdade política, com a instauração de uma ditadura (CORREIO DA MANHÃ, 1964a).

É interessante notar que essas faltas correspondem aos sentimentos de opressão e de desconfiança, da quebra de expectativa do povo em seu governante. Esses dois sentimentos sustentam o efeito de sentido da indignação que, por sua vez, se constitui no motor passional que justifica a ação "vitoriosa" da "nação" contra o "Presidente João Goulart". Essa vitória gera os sentimentos de justiça e de satisfação, efeitos passionais que permeiam o tom eufórico do discurso dos dois jornais. No entanto, o discurso do Correio da Manhã não manifesta uma satisfação ingênua, pois seu editorial enuncia sua preocupação com o porvir e se mostra de prontidão a um possível regime de exceção:

Todavia, estamos em nossos postos, prontos para defender a Constituição, - Congresso Nacional, a democracia, a liberdade. O afastamento do govêrno do sr. João Goulart não justifica de modo algum um regime de exceção. Não justifica violências nem crimes cometidos contra a liberdade individual e coletiva (CORREIO DA MANHÃ, 1964a).

Quanto às duas notas comentário relatado, estas simulam a enunciação das vozes das Forças Armadas reforçam a opinião exposta no editorial desse jornal, bem como seus efeitos passionais. Por outro lado, a nota comentário relatado que simula a enunciação do discurso de João Goulart projeta as imagens do herói e do antiherói no governo Goulart e nas forças reacionárias, respectivamente.

Instala-se no enunciado o sujeito João Goulart que se coloca como defensor das "instituições democráticas", da "econômica da Pátria", dos "princípios cristãos de justiça social", do "ideário de Vargas", das "lutas nacionalistas", da "igreja Católica e demais credos religiosos", enfim valores defendidos pelo sujeito João Goulart e caros à Nação, mas que foram atacados pelo sujeito "forças reacionárias". 
Diferentemente do editorial e das notas anteriores, essa nota discursiviza basicamente uma falta, a usurpação do governo por aqueles que traíram a Pátria, a partir da qual emergem sentimentos como a revolta e a indignação contra aqueles que lhe dispensaram "ódios e paixões", quando seu governo ofereceu "princípios cristãos de justiça social". No entanto, é preciso considerar que o posicionamento da primeira página do Correio da Manhã é contrário a João Goulart, logo os sentidos emados de sua nota comentário relatado devem ser lidos sob a doxa do Correio da Manhã, mas não sob a de João Goulart.

Assim, em síntese, podemos esboçar o seguinte cenário passional:

- A disposição do sujeito apaixonado: o jornal e seu leitor (identificados com "a nação brasileira", fundidos em um só sujeito) experimentam a opressão (João Goulart cerceia a liberdade do povo), a desconfiança (uma ditadura será instalada), a justiça (o povo afasta João Goulart), a satisfação (a liberdade e a legalidade saíram vitoriosas), a preocupação e a inquietude (quem assumirá a presidência?);

- O sujeito desencadeador da paixão: o presidente João Goulart;

- Os motivos que suscitam a paixão: a "nefasta administração que causava o tumulto e a desordem".

Passemos à análise d'O Globo. $O$ enunciador $O$ Globo instala em seu enunciado um sujeito heroico e católico ("Forças Armadas", "bravos militares", "Providência Divina") que restitui a um sujeito vitimado ("Brasil", "os brasileiro", "o povo") valores como "a paz", "a tranquilidade", "o progresso":

\footnotetext{
Atendendo aos anseios nacionais, de paz, tranquilidade e progresso, impossibilitados, nos últimos tempos, pela ação subversiva orientada pelo Palácio do Planalto, as Fôrças Armadas chamaram a si a tarefa de restaurar a Nação na integridade de seus direitos, livrando-a do amargo fim que the estava reservado pelos vermelhos que haviam envolvido o Executivo Federal (O GLOBO, 1964a).
}

Instala-se no "povo" o sentimento da incerteza (falta de esperança), que é compartilhada pelo jornal. Mas, ao construir o herói, constrói-se a expectativa do povo nas Forças Armadas, gerando o efeito passional da esperança, porém uma esperança passiva, em que o sujeito não é o agente da ação transformadora, pois a transformação fica a cargo de outro sujeito: as Forças Armadas. É interessante notar que o discurso d'O Globo não constrói o sentimento da preocupação (como vimos no Correio da Manhã), deixando predominar o tom eufórico de satisfação pela 
deposição de João Goulart. Eis outro ponto de divergência entre os discursos do Correio da Manhã e d'O Globo.

Como dissemos, $O$ Globo cria o efeito de documentar os fatos por meio dos gêneros foto-legenda e foto-manchete. $O$ enunciador $O$ Globo instala no enunciado da foto-manchete "Coragem e emoção" (vide Quadro 3, Texto 3) o sujeito "governador Carlos Lacerda", opositor ao governo Goulart, exaltando sua coragem e tratando do episódio da chegada dos tanques de guerra com apelo emocional e sensacionalista.

Em síntese, podemos esboçar o seguinte cenário passional:

- A disposição do sujeito apaixonado: o jornal e seu leitor (identificados com "a nação brasileira", fundidos em um só sujeito) experimentam a incerteza, a falta de esperança ( $O$ povo não confia no futuro do país sob o governo de João Goulart), a esperança (as Forças Armadas afastam João Goulart), a satisfação (superação da crise sem maiores sofrimentos e luto);

- O sujeito desencadeador da paixão: Forças Armadas;

- Os motivos que suscitam a paixão: falta de paz, tranquilidade e progresso.

A análise do pathos discursivo, porém, não se basta à descrição do cenário passional, pois a construção da imagem de uma "nação" oprimida (Correio da Manhã) ou sem esperança ( $O$ Globo) no plano do enunciado tem implicações no plano da enunciação, aquele em que consideramos o estatuto do enunciador e do coenunciador na situação de comunicação.

O leitor do jornal, o coenunciador, é também um brasileiro, parte do povo; assim, ao ler a primeira página, ele se identifica com esse "povo" caracterizado pelo jornal e os efeitos passionais que se manifestam no plano da enunciação são o da opressão (Correio da Manhã) e o da incerteza (O Globo). Dessa maneira, é por meio da cena enunciativa projetada pelo hipergênero "primeira página" que esse sujeito leitor/povo é persuadido:

- Pelo Correio da Manhã, a vencer o medo e tornar-se o sujeito da deliberação ${ }^{46}$, transformando o presidente João Goulart em seu antisujeito;

\footnotetext{
${ }^{46}$ Aristóteles $(2000$, p. 31) já nos mostra que "para temer é preciso guardar no íntimo alguma
} esperança de salvação, com respeito àquilo pelo que se luta [...]: o temor nos torna aptos a deliberar". 
- Por O Globo, a confiar nas Forças Armadas e a manter-se como sujeito paciente, assistindo ao afastamento do presidente João Goulart (seu antisujeito) pelas Forças Armadas, que ocupam o lugar do sujeito ativo, governante.

No editorial "Vitória", o jornal Correio da Manhã orienta seu leitor/povo a ser o sujeito de fato, ao passo que o editorial "Ressurge a Democracia!", d'O Globo, constrói um sujeito que é um objeto. Considerando que o engajamento e a alienação política foram atitudes (prenhes de valores) marcantes para a vida política naquele período, parece-nos bastante significativo que, do ponto de vista da orientação argumentativa, uma das diferenças mais notáveis entre os editoriais desses dois jornais incida sobre o posicionamento que o jornal e o seu leitor devem adotar perante os fatos políticos de abril de 1964: assistir ou agir? Eis a questão.

Podemos dizer que o pathos construído pelo discurso do Correio da Manhã volta-se para a mobilização do leitor em direção à participação do momento político pelo qual passa o País, diferentemente do pathos do discurso d'O Globo que orienta seu leitor para a direção contrária. Tendo em vista que, naquele contexto sóciohistórico, há uma disputa entre as formações discursivas "revolucionária" e "antigolpista" sobre o sentido da palavra "democracia" e relacionando as paixões construídas pelos discursos jornalísticos do Correio da Manhã e d'O Globo ao sistema de valores do regime democrático, veremos que o discurso do Correio da Manhã está mais próximo do que o discurso d'O Globo daquilo que parece ser um valor fundamental à democracia, que está na própria origem etimológica da palavra "democracia": a participação do povo.

No que tange ao papel do pathos na construção do ethos discursivo, notaremos como os pathé dos discursos do Correio da Manhã e d'O Globo servem de subsídio para a depreensão do tom e do caráter desses enunciadores institucionais.

O discurso do Correio da Manhã, ao tocar seu leitor por meio do sentimento de justiça (o povo afasta João Goulart) e da satisfação (a liberdade e a legalidade saíram vitoriosas), é enunciado num tom eufórico, porém resguardado, pois se mostra preocupado com o porvir, ao despertar as paixões da preocupação e da inquietude (quem assumirá a presidência?).

Por outro lado, o discurso d'O Globo é enunciado num tom amplamente eufórico, pois, após fazer com que o leitor experimentasse as paixões da incerteza e 
da falta de esperança (O povo não confia no futuro do país sob o governo de João Goulart), constrói um mundo de heróis e de vilões, em que o povo é a vítima indefesa que assiste às Forças Armadas banirem os "vermelhos que envolveram o executivo Federal", fazendo, assim, com que seu leitor passasse a experimentar a esperança (as Forças Armadas afastam João Goulart) e a satisfação (superação da crise sem maiores sofrimentos e luto).

Entendendo que o ethos institucional do jornal corresponde ao modo de ser e de se comportar na esfera jornalística de uma dada sociedade, podemos dizer que desse discurso do Correio da Manhã emerge o ethos de um jornal atuante, distintamente do discurso d'O Globo do qual emerge o ethos do jornal espectador. É preciso dizer que esses qualificadores "atuante" e "espectador" são uma tentativa de recobrir com apenas uma palavra a qualidade que traduz o modo de presença apresentado por cada um desses jornais no interior da polêmica em torno dos acontecimentos políticos de abril de 1964. E, com o mesmo resultado imperfeito, outros qualificadores serão empregados nas análises das demais edições, sempre nessa mesma tentativa de encontrar a palavra perfeita. No entanto, o que queremos destacar com essa justificativa não é o qualificador que será atribuído ao ethos de cada jornal, mas sim que os discursos do Correio da Manhã e d'O Globo inscrevemse em formações discursivas distintas e que a enunciação de seus discursos é legitimada, cada qual, por um ethos diferente, revelando que a polêmica entre os discursos instaura-se não apenas por meio daquilo que é dito, como também por meio do seu modo de dizer.

Assim, esse ethos atuante suscita a memória de um corpo enunciante historicamente especificado (o dos jornais que lutaram pela liberdade, pela democracia) e, ao mesmo tempo, suscita o anti-ethos não atuante (espectador), que abrange a imagem de seu anti-sujeito, daquele que investe contra os valores veiculados pelo ethos. Se o Correio da Manhã polemiza com João Goulart na esfera política, é na esfera jornalística que esse jornal se contrapõe a um jornalismo alinhado ao establishment, "seja quem for". Esse anti-ethos produzido pelo discurso do Correio da Manhã é endereçado aos jornais espectadores, que mais tarde viriam a aceitar a República forjada pelo regime militar.

Por sua vez, o ethos espectador construído pelo discurso d'O Globo suscita um corpo enunciante também historicamente especificado: daqueles que esperam que alguém faça por ele o seu dever. Se o discurso d'O Globo cria identificação com 
o povo no sentido de confiar às Forças Armadas a tarefa de restituir a democracia, é tão somente as Forças Armadas que podem exercer o direito de realizar tal tarefa, mais ninguém. E, nesse processo, também é importante destacar a construção do anti-ethos não espectador (atuante), que corresponde à imagem do anti-sujeito d' $O$ Globo. Assim, o ethos de espectador d'O Globo mais o seu anti-ethos atuante captam o imaginário do leitor, convidando-o a fazer parte desse corpo de pessoas que confiam nas Forças Armadas e rechaçam os "agitadores subversivos".

Parece-nos que é assim que esses ethé e pathé construídos nas primeiras páginas analisadas dão contornos aos sujeitos que emergem do discurso jornalístico do Correio da Manhã e d'O Globo e legitimam seus discursos, suas identidades discursivas e suas respectivas inscrições nas formações discursivas das quais eles enunciam. 


\subsection{Análise das primeiras páginas das edições de 3 de abril}

No prolongamento das edições do dia anterior, as edições de 3 de abril de 1964 ainda se voltam aos desdobramentos das primeiras ações daquele movimento político, porém passam a focalizar o processo de legitimação do movimento político via votação no Congresso Nacional. O Quadro 9 dispõe os títulos que compõem as primeiras páginas do Correio da Manhã e d'O Globo dessa edição de 3 de abril.

Quadro 9 - Títulos das capas do Correio da Manhã e d'O Globo de 03.04.1964

\begin{tabular}{|c|c|c|c|c|}
\hline \multirow{2}{*}{$\begin{array}{l}\text { FINALID } \\
\text { ADE }\end{array}$} & \multicolumn{2}{|c|}{ Correio da Manhã } & \multicolumn{2}{|r|}{ O Globo } \\
\hline & Gênero & Título & Gênero & Título \\
\hline \multirow{2}{*}{ 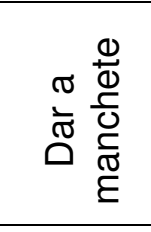 } & Manchete & $\begin{array}{l}\text { ADEMAR DESAFIA O } \\
\text { CONGRESSO }\end{array}$ & Manchete & $\begin{array}{c}\text { MAIS DE } 800 \mathrm{MIL} \\
\text { PESSOAS NA "MARCHA } \\
\text { DA VITÓRIA"! }\end{array}$ \\
\hline & & & $\begin{array}{c}\text { Foto- } \\
\text { manchete }\end{array}$ & (sem título) \\
\hline$\frac{\bar{\sigma}}{\overline{\frac{一}{0}}}$ & Editorial & TERRORISMO, NÃO! & Editorial & A VEZ DO CONGRESSO \\
\hline \multirow{3}{*}{ 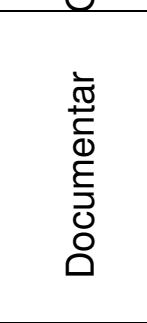 } & $\begin{array}{c}\text { Foto- } \\
\text { legenda }\end{array}$ & Mazzilli toma posse & $\begin{array}{c}\text { Foto- } \\
\text { legenda }\end{array}$ & (sem título) \\
\hline & & & $\begin{array}{l}\text { Foto- } \\
\text { legenda }\end{array}$ & $\begin{array}{c}\text { O GENERAL MOURÃO } \\
\text { CONTA A HISTÓRIA DA } \\
\text { REVOLTA }\end{array}$ \\
\hline & & & $\begin{array}{l}\text { Foto- } \\
\text { legenda }\end{array}$ & TRADIÇÃO DE LIBERDADE \\
\hline \multirow{10}{*}{$\frac{. \overline{0}}{\frac{\pi}{0}}$} & Notícia & (contígua à manchete) & $\begin{array}{c}\text { Notícia } \\
\text { com } \\
\text { chamada }\end{array}$ & $\begin{array}{c}\text { MAZZILI CHEGA HOJE AO } \\
\text { RIO PARA FORMAR O } \\
\text { NÔVO GOVÊRNO }\end{array}$ \\
\hline & Notícia & $\begin{array}{l}\text { MONTEVIDÉU AINDA } \\
\text { AGUARDA GOULART }\end{array}$ & Chamada & $\begin{array}{l}\text { FALCÃO PEDE PUNIÇÃO } \\
\text { PARA OS CRIMINOSOS }\end{array}$ \\
\hline & Notícia & $\begin{array}{c}\text { BARRICADAS CERCAM } \\
\text { DOIS FORTES NA ZS }\end{array}$ & Chamada & $\begin{array}{c}\text { Eleição Imediata do } \\
\text { Presidente Pelo Congresso }\end{array}$ \\
\hline & Notícia & $\begin{array}{c}\text { LYNDON JOHNSON } \\
\text { ENVIA FELICITAÇÕES A } \\
\text { MAZZILLI }\end{array}$ & & \\
\hline & Notícia & $\begin{array}{c}\text { Paralisado tráfego na Frei } \\
\text { Caneca }\end{array}$ & & \\
\hline & Notícia & $\begin{array}{l}\text { LACERDA A KRUEL: } \\
\text { ELEIÇÃO IMEDIATA }\end{array}$ & & \\
\hline & Notícia & $\begin{array}{l}\text { Ex-ministros detidos e } \\
\text { soltos em SP }\end{array}$ & & \\
\hline & Notícia & \begin{tabular}{|c|} 
MAZZILLI FALA SÔBRE \\
AS PRISÕES \\
\end{tabular} & & \\
\hline & Notícia & $\begin{array}{c}\text { Seixas Dória chega prêso } \\
\text { a Salvador }\end{array}$ & & \\
\hline & Notícia & Bancos só abrirão 2ª-feira & & \\
\hline
\end{tabular}




\subsubsection{As manchetes}

Se as manchetes de 2 de abril de 1964 do Correio da Manhã e d'O Globo voltaram-se para a posse de Mazzilli no lugar do presidente deposto em $1^{\circ}$ de abril, as de 3 de abril destacaram acontecimentos diferentes. O título da primeira página do Correio da Manhã é a manchete "Ademar desafia o congresso", enquanto o título da capa d'O Globo traz a manchete "Mais de 800 mil pessoas na 'Marcha da Vitória'!".

Como a manchete é um forte elemento de homogeneização do sentido da primeira página do jornal, esses dois títulos projetam, para toda a página, cenas enunciativas bem distintas. No Correio da Manhã, constrói-se uma cenografia do duelo, pois, diante dos fatos políticos em curso, a midiatização da relação entre o governo do estado de São Paulo e o Congresso Nacional nos termos de um "desafio", que é incitação ao duelo, produz o efeito de sentido de tensão e de acirramento dos ânimos, o que traz consequências em termos de pathos. N'O Globo, a manchete e a foto-manchete (Figura 13) produzem a cenografia do triunfo, pois apresentam como acontecimento do dia anterior a "Marcha da Família com Deus pela Liberdade", na qual o "povo" tomou as ruas da Guanabara para demonstrar seu "repúdio ao comunismo" e comemorar a "vitória" sobre João Goulart:

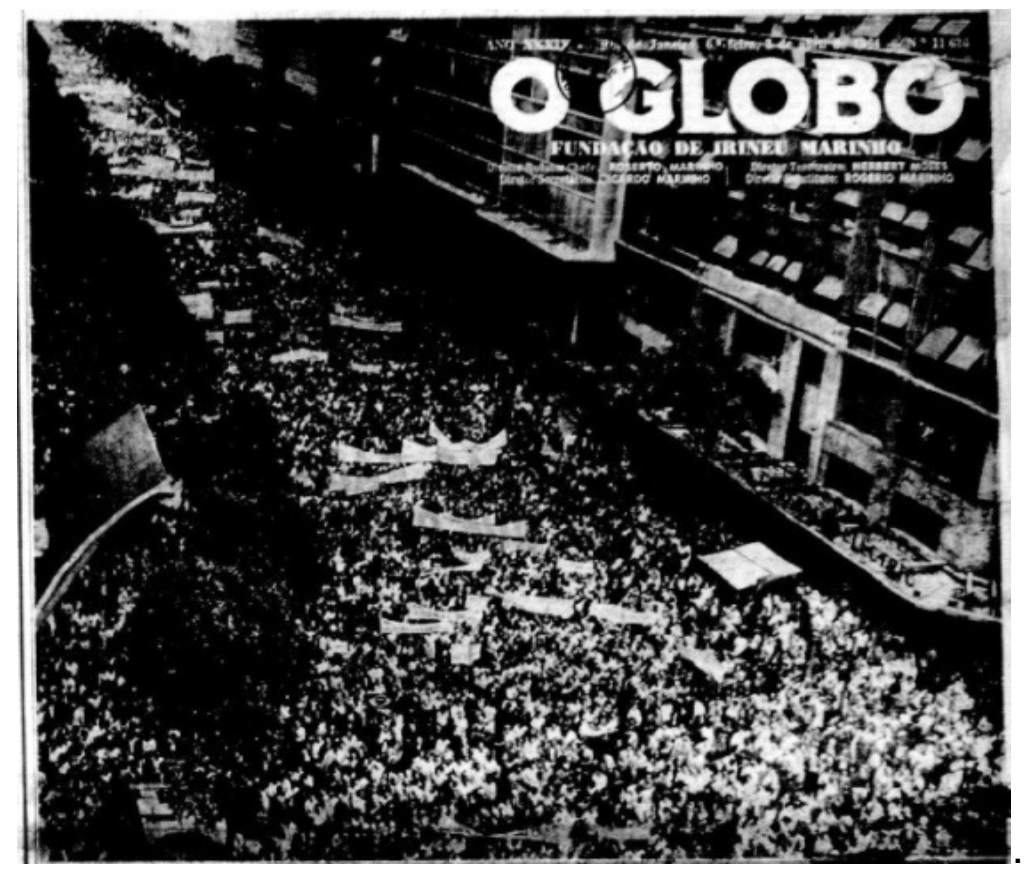

Figura 13 - Fotografia da foto-manchete da capa d'O Globo de 03.04.64 
É possível notar que a diferença entre as duas cenas criadas pelas manchetes produz diferenças no tom dos jornais. Depreende-se que o tom do Correio da Manhã é tenso e coloca o espírito do leitor em estado de alerta e que, por sua vez, o tom d'O Globo é eufórico e corrobora o momento de triunfo vivido pelos "revolucionários".

Das manchetes e fotos-manchetes do Correio da Manhã e d'O Globo, emergem posicionamentos bem definidos nessa polêmica entre "revolucionários" e "antigolpistas", pois o Correio da Manhã denuncia as faltas à democracia cometidas pelos "revolucionários", enquanto $O$ Globo coloca-se como o jornal entusiasta do movimento político de 1964 . 


\subsubsection{Os editoriais}

Ao enunciar "Terrorismo, não!", o editorial do Correio da Manhã soma à cenografia do duelo a projeção de uma cenografia do terror. Atribui a imagem de terrorista ao governador Carlos Lacerda, ao Ihe associar as ações repressivas da polícia do estado da Guanabara, e também ao governador de São Paulo, ao denunciá-lo pela nomeação de "interventores para os órgãos oficiais e de ameaçar o Congresso". O que o jornal começa a fazer é denunciar e reprovar o terrorismo de estado que viria a se instalar no Brasil durante os chamados "anos de chumbo".

Nessa cenografia, as vítimas da ação terrorista são lexicalizadas como "jornalistas", "adversários de um candidato à Presidência", "Congresso", ou seja, os atores sociais responsáveis pela informação, pelo jogo democrático e pela legislação do País.

A tensão, o duelo e o terror são estabelecidos em razão do conflito entre uma doxa democrática e uma doxa antidemocrática, pois, para o Correio da Manhã, o que está em jogo é a organização de um "totalitarismo de direita para o esmagamento das liberdades democráticas".

Os valores defendidos pelo jornal são lexicalizados como "vitória da Nação", "evitar a sua [de João Goulart] manobra continuísta", "as liberdades democráticas", "a disciplina, a ordem, o regime", "[a] inviolabilidade [...] garantida pela Constituição", "um nôvo e legítimo presidente da República", "Congresso Nacional [...] soberano".

Por outro lado, os valores rechaçados pelo discurso do Correio da Manhã manifestam-se por meio de itens lexicais como "maculada", "arbitrariedade e [...] violências", "Estado de sítio", "manchar de sangue, como já se manchou, um movimento de amplitude nacional", "prendendo e espancando como se estivéssemos em plena ditadura", "a investida brutal do totalitarismo de direita", "a indisciplina, a desordem e a ilegalidade", "ameaça" e "humilhação".

A opinião do jornal manifesta-se num tom assertivo e seus enunciados são marcados pelas modalidades epistêmica e deôntica, como, por exemplo, em "[...] o que existe, na realidade, é um desabafo patológico do sr. Carlos Lacerda". Esse tom reforça o efeito de verdade em torno dos fatos construídos pelo discurso jornalístico e orienta o leitor na direção de aceitar as atitudes que devem ser tomadas para que os valores defendidos pelo jornal prevaleçam no movimento político, como no 
enunciado "O sr. Ranieri Mazzilli [...], o Exército e o povo [...] têm obrigação de estar ao seu lado [da Constituição] neste momento e recusar qualquer ameaça".

Assim, o Correio da Manhã associa os valores democráticos ao recémempossado presidente Raniere Mazzilli, ao Exército e ao povo, atribuindo-Ihes o papel de defensores da Constituição, ao passo que projeta diretamente os valores antidemocráticos aos governadores da Guanabara (Carlos Lacerda) e de São Paulo (Ademar de Barros), conferindo a esses atores políticos a imagem de "terroristas".

Nessa disputa entre "revolucionários" e "antigolpistas" pelo poder de se assumir como democrático e imputar ao seu adversário a pecha de antidemocrático, - Correio da Manhã elege o Congresso Nacional como foro privilegiado de defesa dos valores defendidos pelo jornal:

O Congresso Nacional é soberano e não pode agir sob pressão de ninguém. Assim como reagiu contra o sr. João Goulart deve reagir contra os srs. Ademar de Barros e Carlos Lacerda (CORREIO DA MANHÃ, 1964b).

É interessante observar que $O$ Globo também atribui ao Congresso Nacional um papel fundamental no movimento político de 1964, que, naquele primeiro momento, trabalhava para construir sua legitimidade perante a população brasileira e a comunidade internacional, pois, caso contrário, a dita "revolução" assumiria ares golpistas, o que é negado até hoje pelos ditos "revolucionários".

O editorial d'O Globo, com o título "A vez do Congresso", exorta o Congresso Nacional a completar a tarefa iniciada pelas Forças Armadas e, tal como no discurso do Correio da Manhã, essa exortação também se baseia na axiologização entre democrático versus antidemocrático, porém é preciso notar que esses dois polos axiológicos assumem matizes diferentes no discurso d'O Globo.

Comecemos observando que os valores democráticos defendidos pelo jornal O Globo - que se enuncia como "democrata" - manifestam-se lexicalmente da seguinte maneira: "a democracia", "as instituições", "progresso e harmonia social", "movimento sindical brasileiro [...] poderoso e ativo, mas [...] livre e apolítico", "nossa economia", "lei de defesa do Estado" etc. Defende a democracia e as instituições, o progresso e a harmonia social. Entende que os sindicatos devem ser apolíticos, ou seja, que atuem sem a orientação política de esquerda. Valorizam a economia e desejam a aprovação de uma lei de defesa do Estado, isto é, uma lei de endurecimento do combate aos "comunistas". Enfim, esses são os elementos que constituem os valores democráticos para $O$ Globo. 
Por outro lado, os valores antidemocráticos rechaçados pel'O Globo aparecem na forma de: "orientação demagógica, desleal e subversiva do Govêrno demitido", "a subversão e a penetração vermelha”, “o 'socialismo' castrista”, "a politização do sindicalismo nacional", "greves" etc. Contrapõem-se aos valores democráticos a demagogia de João Goulart, a subversão comunista e a revolução cubana.

O editorial d'O Globo repete a construção da cenografia do herói defensor da democracia (as Forças Armadas), do anti-herói (“João Goulart”, "os agitadores e comunistas") e do povo socorrido, de modo que, para o leitor, o Congresso Nacional não tem outro lugar nessa "batalha" que não seja ao lado dos "mocinhos" ("o Congresso estará bem atento ao que o povo dêle espera"). Assim como no Correio da Manhã, o tom d'O Globo também é assertivo e seus enunciados são marcados pelas modalidades epistêmica e deôntica:

(7) A VERDADE, porém, é uma só. O Brasil estava sendo destruído, para que, sôbre seus escombros, viesse a erguer-se uma ditadura do tipo cubano.

(8) DEVE O CONGRESSO completar, sem mais tardança, a tarefa iniciada pelos militares.

(9) Urge, assim, que o Legislativo forneça, imediatamente, ao nôvo Govêrno [...].

(10)O substituto do Sr. João Goulart tem que ser eleito já pelos congressistas [...].

(11)PRECISA O CONGRESSO ter uma inspiração de grandeza [...]

O enunciado em (7) revela uma atitude epistêmica de certeza do enunciador O Globo perante a proposição "o Brasil estava sendo destruído, para que [...] viesse a ergue-se uma ditadura do tipo cubano". Essa certeza de que os valores presumidamente democráticos seriam destruídos em nome dos valores antidemocráticos (lexicalizado em "ditadura do tipo cubano") não apenas explicita ao leitor o posicionamento do jornal perante os fatos por ele construídos, como também se apresenta como o argumento que sustenta a exortação que o jornal dirige ao Congresso Nacional por meio de enunciados marcados pela modalidade deôntica, no sentido de dizer o que o outro deve fazer, tal como podemos notar nos enunciados em (8), (9), (10) e (11). A orientação argumentativa desse editorial d'O 
Globo é conduzir o leitor a compreender que, em nome da democracia, o Congresso Nacional deve eleger o novo presidente imediatamente.

Considerando a memória discursiva sobre o regime político conhecido por "democracia", é notável a contradição encontrada no discurso desse editorial d'O Globo. O jornal apresenta-se como "um democrata" e, ao mesmo tempo, defende - em nome da democracia - eleições indiretas para Presidente da República, sem a campanha eleitoral e o debate de ideias entre os candidatos. $O$ jornal propugna também que 0 novo governo haja acima das leis. A esse respeito, vale conferir o parágrafo na íntegra:

POIS O NÔVO Govêrno terá que fazer, em pouco tempo, aquilo que o anterior deixou de fazer em dois anos e meio de atuação insensata e nociva. Deve, inclusive, impor-se de tal maneira a todos os campos políticos e ideológicos que iá não suriam obstáculos à votação das leis destinadas a melhorar as condições de vida do homem brasileiro, vítima das desigualdades sociais decorrentes do desenvolvimento desordenado $(\mathrm{O}$ GLOBO, 1964b) [grifo nosso].

O Globo defende um regime democrático em que se anula o espaço público destinado à defesa de posições e à tomada de decisões consensuais, o Congresso Nacional. Os discursos do Correio da Manhã e d'O Globo defendem os valores democráticos, mas é patente como o sentido de "democracia" desliza de um discurso para o outro. É igualmente importante ressaltar como o discurso da demonização do comunismo e glorificação das Forças Armadas aparece apenas n'O Globo, corroborando o discurso "revolucionário", diferentemente do que ocorre no discurso do Correio da Manhã:

ENFIM, É imprescindível que o Congresso não decepcione os democratas nem incorra em erros que venham a servir aos comunistas ora em debandada. Necessita agir bem e depressa, até mesmo para que o povo e as Fôrças Armadas não venham a pensar que caíram num Primeiro de Abril (O GLOBO, 1964b).

Se a análise dos editoriais das edições de 2 de abril do Correio da Manhã e d'O Globo nos permitiu notar que, embora não houvesse oposição àquele movimento político por parte da grande imprensa, esses dois jornais não reproduzem o mesmo discurso sobre a deposição de João Goulart, esta análise dos editoriais de 3 de abril confirma a divergência que há entre o posicionamento discursivo do Correio da Manhã e d'O Globo e como o primeiro começa a se inscrever numa formação discursiva dita "antigolpista", enquanto o segundo, numa formação discursiva dita "revolucionária". 


\subsubsection{As fotos-legendas}

O Correio da Manhã não apresentou em sua edição de 3 de abril de 19640 gênero nota comentário relatado e recorreu somente uma vez ao gênero fotolegenda. Já $O$ Globo recorreu duas vezes ao gênero foto-legenda para compor sua primeira página. Ocorre que a primeira página dessa edição do Correio da Manhã prioriza o noticiário, enquanto que o espaço da primeira página d'O Globo é, predominantemente, tomado pelo editorial e pela foto-manchete.

A foto-legenda intitulada "Mazzilli toma posse" ocupa posição de destaque na primeira página, ao se localizar na metade superior da página, o efeito de sentido de real criado pela imagem fotográfica reforça o fato de que o País tem um novo presidente que, de acordo com a legenda, é empossado de maneira legítima pelo "presidente do Supremo Tribunal Federal" e pelo "presidente do Senado Federal".

Assim, o que parece ser apenas uma informação é a reprodução do discurso da manutenção das instituições democráticas, é a tentativa de o jornal mostrar como o Brasil se mantém num regime político democrático. Esse discurso é a resposta ao que o jornal entende como terrorismo (questionado no editorial) e ameaça à democracia (denunciada na manchete e na notícia contígua à manchete). Esse é o sentido que vai se construindo na metade superior da primeira página do Correio da Manhã.

No que tange à primeira página d'O Globo, a metade superior da página e quase um terço da metade inferior da página são ocupadas pelo conjunto manchete e foto-manchete e pelo editorial, restando aproximadamente um terço da metade inferior para os demais gêneros, dentre eles três fotos-legendas, sendo uma sem título (Quadro 5, texto 4), uma intitulada "O General Mourão conta a história da revolta" (Quadro 5, texto 6) e a outra, "Tradição de liberdade” (Quadro 5, texto 7). É interessante notar que as imagens fotográficas enunciadas pela primeira página d' $O$ Globo como simulacro do real são construídas como símbolos da chamada "Revolução", os quais são apreciados positivamente por esse discurso jornalístico nas legendas das fotografias, sendo incorporados pelo discurso d'O Globo.

Como dissemos na análise das fotos-legendas da edição de 2 de abril d'O Globo, esse jornal capta a adesão de seu leitor por meio daquilo que Marcondes Filho (2002) chama de ideologia do flash, isto é, ao invés de reproduzir os argumentos dos discursos dos chamados líderes revolucionários, expõe o leitor a imagens fotográficas cujos sentidos são ressignificados pelas legendas. 
O que as imagens da Figura 14 dizem isoladamente?

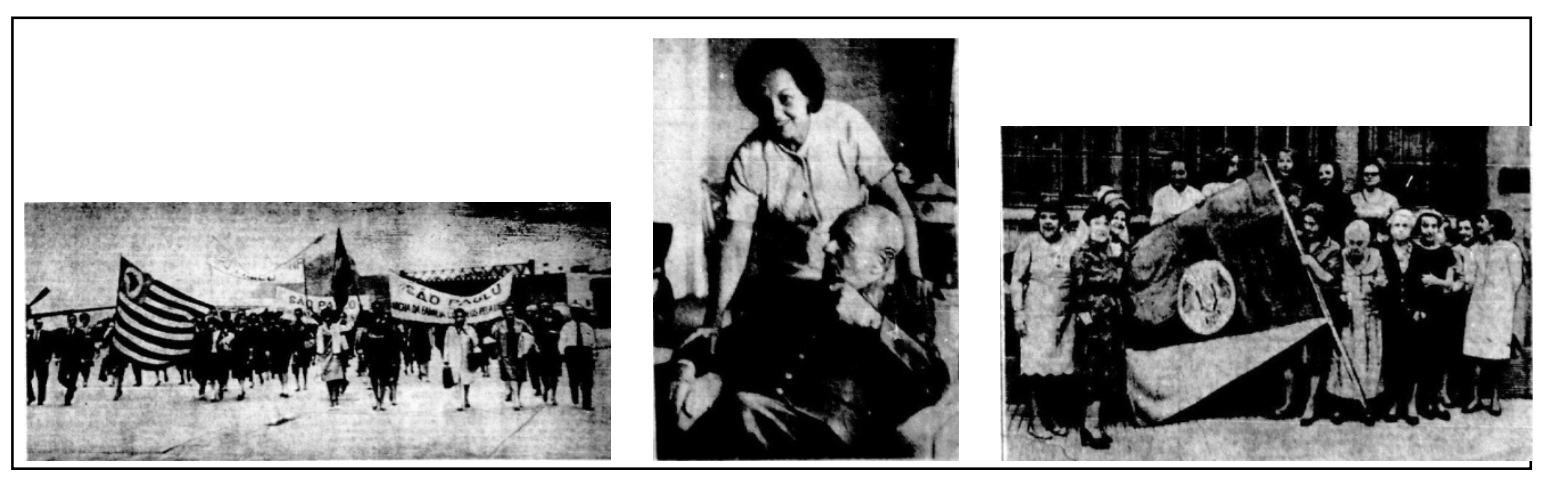

Figura 14 - Fotografias das fotos-legendas d'O Globo de 03.04.1964

As fotografias por si só mostram um conjunto de pessoas trazendo bandeiras do estado de São Paulo, uma senhora de pé acompanhando um senhor que está sentado em sua poltrona, um grupo de senhoras com a bandeira do Rio Grande do Sul. Embora recortada pelo olhar do repóter fotográfico e editada pelo jornal, a imagem fotográfica, isoladamente, não basta para construir o sentido do enunciado, pois a legenda, ao lançar a apreciação valorativa do jornal sobre as imagens, é o que constitui o todo do enunciado do qual podemos depreender o sentido.

Nesse exemplo, podemos ver que as legendas dão conta de relatar que as bandeiras de São Paulo e do Rio Grande do Sul foram desfraldadas durante a "Marcha da Família com Deus pela Liberdade", que é referenciada pelo discurso d'O Globo, em sua manchete, como a "Marcha da Vitória". É interessante observar como esses três textos atualizam a memória discursiva das lutas pela liberdade, pois tanto São Paulo quanto o Rio Grande do Sul lideraram batalhas históricas contra tropas federais, em que o primeiro envolveu-se na Revolução Constitucionalista e o segundo, na Revolução Farroupilha. É preciso dizer, porém, que essa memória discursiva é ressignificada e atualizada de acordo com as categorias semânticas do discurso conversador que $O$ Globo enuncia nas edições de abril de 1964. Tomemos a legenda da foto-legenda "Tradição de liberdade" (Texto 7):

Esta é a histórica bandeira de Piratini, símbolo da tradição de liberdade do povo gaúcho, que foi desfraldada na Marcha da Família com Deus pela Liberdade, ontem à tarde, nas ruas da Guanabara. Trouxeram-na representantes das mais tradicionais famíllias do Rio Grande do Sul, dentre as quais se destacavam D. Francisca Osório Ribeiro e D. Leonídia Osório de Castro, respectivamente neta e bisneta do General Osório, herói da guerra do Paraguai, D. Francisca de têrço na mão, exultou ao receber a notícia da entrada do General Cordeiro de Farias, ontem, em Pôrto Alegre (O GLOBO, 1964b) [grifos nossos]. 
Os itens lexicais grifados remetem a elementos pré-construídos que revelam o discurso conservador que sustenta o discurso "revolucionário", dentre os quais podemos destacar a religiosidade na política ("Deus" e "terço na mão"), o elitismo da tradição familiar ("Família", "as mais tradicionais famílias" e "neta e bisneta do General Osório") e a exaltação aos símbolos do poder ("histórica bandeira" e "símbolo da tradição") e às batalhas do passado ("herói da guerra do Paraguai"). E esse discurso conservador é reforçado pela legenda da foto-legenda "O General Mourão conta a história da revolta" (texto 6):

Em seu apartamento na Avenida Atlântica o chefe militar da revolta democrática iniciada em Minas Gerais recebeu ontem a reportagem de $O$ GLOBO e antes de dar seu depoimento posou ao lado da espôsa (O GLOBO, 1964b) [grifos nossos].

O discurso d'O Globo reitera, nessa legenda, o elitismo da tradição familiar por meio da lexicalização dos itens grifados no excerto acima. Ainda nessa legenda, a chamada "revolução" torna-se "revolta democrática", todavia a contradição do discurso d'O Globo revela-se na valorização positiva dos valores que compõem a doxa desse discurso conservador. Ora, o que podemos observar é que $O$ Globo constrói uma "revolução" que é liderada e sustentada pela classe social que se apresenta como a elite do País, tais como chefes militares, generais, heróis de guerra consagrados na história do Brasil, um grupo de manifestantes de São Paulo que desembarca no aeroporto "Santos Dumont" para participar da "Marcha", entre outros. É importante dizer que os atores sociais que não são representantes de qualquer uma das elites do país têm sua participação apagada pelo discurso d'O Globo, pois é possível notar que nessa "revolução" não há lugar para o pracinha, para a dona de casa, para o trabalhador, entre outros.

Embora as imagens fotográficas da foto-manchete e das fotos-legendas construam o efeito de sentido de participação popular no movimento político de 1964, as legendas dessas imagens atribuem ao leitor do jornal o lugar de mero espectador dos fatos políticos. A cenografia construída por esses gêneros discursivos remete a uma cena validada encontrada nas festas oficiais descritas por Bakhtin ${ }^{47}$ em sua obra sobre Rabelais, ou seja, ao povo cabe assistir de longe à "festa" que acontece no espaço delimitado e apropriado à elite social. Essa

${ }_{47}$ BAKHTIN, Mikhail. A cultura popular na Idade Média e no Renascimento. O contexto de François Rabelais. Brasília: Hucitec, 1987. 
cenografia também tem a função de captar o imaginário do leitor no sentido de que ele pode ficar tranquilo em casa, porque as Forças Armadas e a elite brasileira estão encaminhando a "revolução" dentro dos valores da família, de Deus e da democracia. Dessa maneira, parece justo afirmar que o discurso d'O Globo insere-se na estratégia de ação política promovida pela elite orgânica do IPES para assunção do poder no Brasil. 


\subsubsection{As notícias}

Nessa edição de 3 de abril, a primeira página do Correio da Manhã é, predominantemente, ocupada pelo gênero discursivo "notícia", ao passo que a primeira página d'O Globo publica apenas uma notícia, que aliás é uma pequena notícia com chamada para aprofundamento intitulada "Mazzili chega hoje ao Rio para formar o nôvo govêrno".

O Correio da Manhã publica uma notícia contígua à manchete "Ademar desafia o Congresso" (Quadro 4, Texto 2) e mais as seguintes notícias:

- "Montevidéu ainda aguarda Goulart" (Quadro 4, Texto 3);

- "Barricadas cercam dois fortes na ZS" (Quadro 4, Texto 4);

- "Lyndon Johnson envia felicitações a Mazzilli" (Quadro 4, Texto 6);

- "Paralisado tráfego na Frei Caneca" (Quadro 4, Texto 7);

- "Lacerda a Kruel: eleição imediata" (Quadro 4, Texto 8);

- "Ex-ministros detidos e soltos em São Paulo" (Quadro 4, Texto 10);

- "Mazzilli fala sôbre as prisões" (Quadro 4, Texto 11);

- "Seixas Dória chega prêso a Salvador" (Quadro 4, Texto 12);

- "Bancos só abrirão 2a--feira" (Quadro 4, Texto 13).

Com base nesses dados, poderíamos dizer que essa primeira página do Correio da Manhã projeta uma cena de enunciação informativa, todavia é necessário ressaltar que o jornal publica nessa página o seu editorial "Terrorismo, não!", cujos sentidos se inter-relacionam com os sentidos das notícias que compõem essa capa do Correio da Manhã, pois (1) a inter-relação entre os gêneros jornalísticos na primeira página é uma característica constitutiva desse hipergênero e (2) os acontecimentos e os atores mencionados, citados e axiologizados no discurso argumentativo do gênero "editorial" são construídos - mais uma vez - na mesma página sob as coerções do gênero "notícia".

Devemos salientar aqui que estamos falando de efeitos de sentido "informativo" e "opinativo", os quais corroboram estratégias argumentativas que orientam o leitor na direção de um ou de outro ponto de vista.

Mostramos na análise do editorial "Terrorismo, não!" que o Correio da Manhã defende os valores democráticos, construindo uma polarização entre os defensores desses valores democráticos (o Congresso Nacional, o recém-empossado Presidente Mazzilli, o povo e o Exército) e os representantes dos valores 
antidemocráticos (os governadores da Guanabara, Carlos Lacerda, e de São Paulo, Ademar de Barros, bem como o presidente deposto João Goulart).

As notícias, ao destinar grande parte de seu espaço ao discurso citado, potencializam a construção do efeito de real, oferecendo ao seu leitor o contato "direto" com o pronunciamento das lideranças políticas do País, sem parecer que o jornal está emitindo seu ponto de vista a todo instante, como se a primeira página não fosse um todo de sentido.

Passemos ao exame das notícias que, segundo o discurso do Correio da Manhã, denunciam a ameaça antidemocrática.

A notícia contígua à manchete "Ademar desafia o Congresso" (Quadro 4, Texto 2) guarda mais semelhanças com uma nota comentário relatado do que com a notícia, pois, ao resumir o pronunciamento que o governador paulista havia feito na noite anterior, a voz do jornalista limita-se a introduzir a voz de Ademar de Barros, que pertence a uma formação discursiva dita "revolucionária". Os excertos a seguir destacam trechos do pronunciamento do governador paulista, por meio dos quais podemos observar como o Correio da Manhã denuncia o totalitalismo (conforme as expressões grifadas abaixo) que permeia o discurso de Ademar de Barros:

Não houve revolução e não haverá conquista de poder, pois nosso objetivo está em preservar a democracia e impor a ordem a qualquer preço.

No momento é preciso fechar o CGT, acabar com os órgãos espúrios, como dizia o ilustre general Peri Constant Bevilacqua, quando comandava 0 glorioso II Exército. Êstes organismos, entretanto, hoje, se encontram fechados, em São Paulo, desde a noite de 31 de março.

É preciso pôr um paradeiro à infiltração comunista que lança suas sementes na indústria, comércio, e entidades estudantis e universitárias e na própria Justiça, bem como na imprensa, nas rádios e nas emissoras de televisão (CORREIO DA MANHÃ, 1964b).

A notícia "Lacerda a Kruel: eleição imediata" (Quadro 4, Texto 8) revela a articulação política do grupo de Carlos Lacerda, então governador da Guanabara, com os militares "revolucionários", no sentido de traçar o perfil do novo presidente e que sua eleição ocorra imediatamente:

O governador Carlos Lacerda propôs ontem ao comandante em chefe do Exército e ao comandante do II Exército a imediata eleição, pelo Congresso do nôvo presidente da República [...]. 
Também o deputado estadual Danilo Nunes, em nome do governador, procurou, neste sentido, o comandante-em-chefe do Exército e o general Amauri Kruel, transmitindo-Ihes a sugestão de que, além de imediata, a escolha recaia em nome apartidário, de prestígio nacional e trânsito nas Fôrças Armadas [...].

Aparentemente, a notícia "Lacerda a Kruel: eleição imediata" não revela posicionamento ideológico definido na polêmica entre "democráticos" versus "antidemocráticos" (instaurada no e pelo discurso do Correio da Manhã) ou entre "revolucionários" versus "antigolpistas" (tal como entendida nesta pesquisa), uma vez que a voz do jornalista não lança apreciações valorativas. No entanto, a abordagem integral da primeira página como um todo de sentido permite-nos observar que a notícia sobre Carlos Lacerda é axiologizada negativamente pelo discurso do Correio da Manhã, uma vez que o posicionamento do editorial ("O Congresso Nacional é soberano e não pode agir sob pressão de ninguém") ressignifica a aparente neutralidade da notícia, ao mesmo tempo em que essa notícia sustenta o ponto de vista do editorial, oferecendo-se como um argumento.

Embora divergente ao discurso de Ademar de Barros, o discurso do Correio da Manhã também rejeita os valores do discurso nacional-reformista de João Goulart. Assim, ao noticiar que "Montevidéu ainda aguarda Goulart" (Quadro 4, Texto 3), o jornal entende que o presidente deposto ainda está no Brasil e que o mesmo ainda pode ser uma ameaça à democracia. Na forma do discurso indireto e da ilha enunciativa (cf Maingueneau, 2002 [1998], p. 151), o Correio da Manhã traz a "ameaçadora" voz de João Goulart da seguinte maneira:

\footnotetext{
Antes de embarcar, o sr. Goulart recomendou ao seu chefe de Gabinete Civil, sr. Darci Ribeiro, ao general Nicolau Fico e ao ex-chefe do DFSP, coronel Lemos Avelar, que organizassem um movimento de resistência em Brasília, durante 48 horas, até que êle "se articulasse no Sul" (CORREIO DA MANHÃ, 1964b) [grifo nosso].
}

Passemos ao exame das notícias que, de acordo com o discurso do Correio da Manhã, sustentam a defesa aos valores democráticos.

A notícia intitulada "Lyndon Johnson envia felicitações a Mazzilli" (Quadro 4, Texto 6), do ponto de vista textual, organiza-se de maneira diferente das demais notícias, pois, ao simular a enunciação da mensagem de Lyndon Johnson na íntegra, apresenta-se, inicialmente, como uma "nota comentário relatado", porém esse mesmo texto apresenta uma sequência de subtítulos e, dessa maneira, arrola uma série de opiniões enunciadas alhures sobre as causas da derrubada do 
presidente João Goulart. E é essa inter-relação de vozes citadas que revela o posicionamento do jornal sobre o acontecimento político noticiado. Assim, considerando o ponto de vista de cada enunciação alheia sobre a queda de João Goulart, elaboramos o Quadro 10 a fim de ilustrar como o diálogo do Correio da Manhã com essas vozes constitui o seu próprio discurso:

Quadro 10 - O discurso citado em "Lyndon Johnson envia felicitações a Mazzilli"

(continua)

\begin{tabular}{|c|c|c|c|}
\hline № & $\begin{array}{l}\text { Enunciador citado e } \\
\text { contorno do discurso citado }\end{array}$ & Enunciação citada & $\begin{array}{l}\text { Posicioname } \\
\text { nto }\end{array}$ \\
\hline 1 & Lyndon B. Johnson: & $\begin{array}{l}\text { "O povo norte-americano acompanhou } \\
\text { com ansiedade as dificuldades políticas } \\
\text { e econômicas enfrentadas por sua } \\
\text { grande nação e admirou a vontade } \\
\text { resoluta da comunidade brasileira para } \\
\text { superar essas dificuldades dentro do } \\
\text { quadro da democracia constitucional e } \\
\text { sem luta civil." }\end{array}$ & $\begin{array}{l}\text { Favorável ao } \\
\text { movimento } \\
\text { político }\end{array}$ \\
\hline 2 & $\begin{array}{l}\text { O "Pravda", órgão do } \\
\text { Partido } \text { Comunista } \\
\text { Soviético, afirmou ontem } \\
\text { que... }\end{array}$ & $\begin{array}{l}\text { "a rebelião dirigida contra Goulart foi } \\
\text { inspirada por Washington" }\end{array}$ & $\begin{array}{l}\text { Desfavorável } \\
\text { ao } \\
\text { movimento } \\
\text { político } \\
\end{array}$ \\
\hline 3 & $\begin{array}{l}\text { o jornal cubano "Hoy" } \\
\text { atacou particularmente } \\
\text { os governadores Carlos } \\
\text { Lacerda, Ademar de } \\
\text { Barros e Magalhães } \\
\text { Pinto, acusando-os de... }\end{array}$ & $\begin{array}{l}\text { "não terem feito outra coisa senão } \\
\text { conspirar em favor da implantação de } \\
\text { um regime tipo fascista no Brasil". }\end{array}$ & $\begin{array}{l}\text { Desfavorável } \\
\text { ao movimento } \\
\text { político }\end{array}$ \\
\hline 4 & $\begin{array}{l}\text { Nelson Rockefeller, } \\
\text { governador do Estado de } \\
\text { Nova York, disse em } \\
\text { entrevista à imprensa } \\
\text { que... }\end{array}$ & $\begin{array}{l}\text { a administração do presidente Lyndon } \\
\text { Johnson é responsável parcialmente } \\
\text { pelos acontecimentos que se } \\
\text { desenrolaram no Brasil, na medida em } \\
\text { que contribuiu para manter as condições } \\
\text { existentes nesse país. }\end{array}$ & $\begin{array}{l}\text { Desfavorável } \\
\text { ao movimento } \\
\text { político }\end{array}$ \\
\hline 5 & $\begin{array}{l}\text { O "The New York Times" } \\
\text { disse ontem } \\
\text { editorialmente que... } \\
\text { Disse ainda que... }\end{array}$ & $\begin{array}{l}\text { João Goulart é "uma espécie socialista } \\
\text { de salão róseo" e que "na América Latina } \\
\text { todo movimento esquerdista causa } \\
\text { frequentemente uma reação da direita". } \\
\text { "os adversários de Goulart não puderam } \\
\text { comprovar que êle estava levando o } \\
\text { Brail para o comunismo, mas se pode } \\
\text { comprovar que o estava levando para o } \\
\text { caos". }\end{array}$ & $\begin{array}{l}\text { Favorável ao } \\
\text { movimento } \\
\text { político }\end{array}$ \\
\hline 6 & $\begin{array}{l}\text { O Jornal católico "Ya", } \\
\text { espanhol, disse que... }\end{array}$ & $\begin{array}{l}\text { a "demagogia da direita reacionária } \\
\text { chefiada pelo governador Lacerda, não } \\
\text { foi menos prejudicial ao presidente João } \\
\text { Goulart do que a demagogia da } \\
\text { esquerda exaltada de Brizola e outros". }\end{array}$ & $\begin{array}{l}\text { Favorável ao } \\
\text { movimento } \\
\text { político }\end{array}$ \\
\hline
\end{tabular}


Quadro 10 - O discurso citado em "Lyndon Johnson envia felicitações a Mazzilli”

(conclusão)

\begin{tabular}{|c|c|c|c|}
\hline № & $\begin{array}{l}\text { Enunciador citado e } \\
\text { contorno do discurso citado }\end{array}$ & Enunciação citada & Posicionamento \\
\hline 7 & $\begin{array}{l}\text { O "Times", de Londres, } \\
\text { declarou que... }\end{array}$ & $\begin{array}{l}\text { "seria uma tragédia para tôda a } \\
\text { América Latina se o Brasil } \\
\text { submergisse num mar de sangue por } \\
\text { incapacidade de fazer frente as } \\
\text { pressões sociais do século XX". }\end{array}$ & $\begin{array}{l}\text { Favorável ao } \\
\text { movimento } \\
\text { político }\end{array}$ \\
\hline 8 & $\begin{array}{l}\text { O jornal independente } \\
\text { "El Mercurio", chileno, } \\
\text { disse ontem que... }\end{array}$ & $\begin{array}{l}\text { a rebelião no Brasil foi provocada por } \\
\text { um movimento surdo para introduzir o } \\
\text { comunismo, pela orientação } \\
\text { demagógica que João Goulart } \\
\text { imprimiu progressivamente a seu } \\
\text { govêrno, pelas complicações } \\
\text { econômicas exploradas pelos } \\
\text { comunistas e também pela pretensão } \\
\text { de se conseguir a ditadura disfarçada } \\
\text { sob aparências legais, através dos } \\
\text { caminhos contrários à vontade da } \\
\text { maioria. }\end{array}$ & $\begin{array}{l}\text { Favorável ao } \\
\text { movimento } \\
\text { político }\end{array}$ \\
\hline
\end{tabular}

O Quadro 10 mostra que há oito ocorrências de discurso citado na notícia "Lyndon Johnson envia felicitações a Mazzilli", sendo que, dessas oito, três são desfavoráveis ao movimento político de 1964, enquanto que cinco são favoráveis à queda de Goulart. O discurso do Correio da Manhã reafirma seu posicionamento favorável à deposição do presidente, mostrando ao seu leitor que essa sua opinião é apoiada pelo jornalismo internacional e pelo presidente dos Estados Unidos da América, sobre o qual paira uma crítica feita por Nelson Rockffeler, a qual é atenuada pelo Correio da Manhã no momento em que diz que o político está em campanha eleitoral para disputar a Presidência dos EUA. Por outro lado, os discursos desfavoráveis ao movimento político de 1964 são construídos de maneira a ser desconsiderados pelo seu leitor, uma vez que as críticas partem do Pravda, jornal do Partido Comunista Soviético, e do Hoy, um jornal cubano. Isso é o mesmo que dizer que não há discurso citado nessa notícia que seja desfavorável à deposição de Goulart.

Na notícia "Mazzilli fala sôbre as prisões" (Quadro 4, Texto 11), vale observar não a nota emitida por Mazzilli, mas o comentário do Correio da Manhã sobre a nota, o qual se mostra satisfeito com as indagações feitas pela imprensa sobre os atos praticados pelos governadores da Guanabara e de São Paulo, sobretudo por modalizá- 
las no grau da incerteza ao empregar o futuro do pretérito no enunciado "[...] atos que estariam sendo praticados pelos governadores da Guanabara e de São Paulo":

"O sr. Presidente Ranieri Mazzilli está totalmente absorvido pela tarefa
preliminar de auscultar e ponderar sôbre as manifestações das fôrças
decorrentes representativas do movimento político-militar que irrompeu
vitoriosamente para a restauração da ordem, da disciplina hierárquica e da
tranquilidade por que tanto ansiava a nação".

Com essa nota, o Gabinete Civil da Presidência da República respondia a indagações de vários setores da imprensa sôbre atos que estariam sendo praticados pelos governadores da Guanabara e de São Paulo (CORREIO DA MANHÂ, 1964b).

No que diz respeito às notícias examinadas a seguir, entendemos que estas não chegam a representar o discurso "antidemocrático", porém elas ajudam a construir a cenografia de um mundo em desordem.

A notícia "Barricadas cercam dois fortes na ZS" relata o aumento da segurança em dois fortes da zona sul da cidade do Rio de Janeiro, devido a "rumores surgidos sôbre uma possível tentativa de assalto", ou seja, o jornal constrói, por meio dessa notícia, a sensação da insegurança e da ameaça permanente. Por sua vez, a notícia "Paralisado tráfego na Frei Caneca" relata a confusão entre os comandos da polícia que se instalou na Guanabara:

Por determinação do Estado-Maior da Polícia Militar do Estado da Guanabara, devido má interpretação de ordens superiores, o tráfego foi suspenso defronte ao Quartel do Regimento Marechal Caetano de Faria [...] (CORREIO DA MANHÃ, 1964b).

Em "Seixas Dória chega prêso a Salvador", relata-se a prisão do governador de Sergipe e, em "Bancos só abrirão 2ª-feira", o restabelecimento dos serviços, da ordem. Em "Ex-ministros detidos e soltos em São Paulo", relata-se a confusão entre a polícia e políticos gaúchos no aeroporto de Congonhas.

Desse modo, podemos dizer que, embora haja o predomínio espacial do gênero "notícia" na primeira página dessa edição do Correio da Manhã, projeta-se, nessa página, uma cena enunciativa da opinião, o que tem consequências para o regime de enunciação e de leitura, uma vez que, nas passagens entre as cenas enunciativas genéricas e a cena hipergenérica, o leitor é constantemente interpelado a confrontar-se com a opinião do jornal, mesmo que a cena genérica instalada pela "notícia" o interpele como consumidor de notícia, de informação. Assim, a orientação argumentativa e o matiz ideológico, que constitutivamente perpassam o processo de 
recorte do acontecimento e produção da informação jornalística, são potencializados pela cena hipergenérica da primeira página do Correio da Manhã.

\subsubsection{Os pathé e os ethé das primeiras páginas}

No editorial de 3 de abril, o enunciador Correio da Manhã constrói um conflito entre duas forças distintas, sendo uma "democrática" e outra "antidemocrática", alertando sobre o risco da implantação de um "totalitarismo de direita para o esmagamento das liberdades democráticas".

O discurso do Correio da Manhã mostra-se preocupado não exatamente com o governo João Goulart, mas sim com a ameaça às liberdades democráticas. Em seu editorial, repetem-se fórmulas como "vitória da Nação", "evitar a sua [de João Goulart] manobra continuísta" e "as liberdades democráticas". E essa mesma preocupação que ajudou a delinear a contrução do pathos e do ethos da primeira página do Correio da Manhã de 2 de abril é atualizada no editorial de 3 de abril, porém o sujeito que desperta essa preocupação deixa de ser João Goulart e passa a ser o "totalitarismo de direita".

A reiteração dessa preocupação nas edições do Correio da Manhã deve ser observada como uma gradação passional, já que a análise isolada de uma edição revela apenas paixões como a preocupação e a inquietude, ao passo que a análise da midiatização cotidiana dessas paixões mostra que a reiteração dessa paixão aumenta a sua própria intensidade, transformando-a em desconfiança e, depois, em temor. Nessa perspectiva, podemos dizer que a paixão construída no discurso do Correio da Manhã em seu editorial "Terrorismo, não!" é o medo, mais especificamente o medo da instalação de uma ditadura no Brasil.

Dessa maneira, é possível notar que dão o tom ao discurso temeroso do Correio da Manhã enunciados como "arbitrariedade e [...] violências", "Estado de sítio", "manchar de sangue, como já se manchou, um movimento de amplitude nacional", "prendendo e espancando como se estivéssemos em plena ditadura", "a investida brutal do totalitarismo de direita". Essa situação que desencadeia o temor é contraposta na foto-legenda, da qual já depreendemos, anteriormente, um discurso de resistência favorável à manutenção das instituições democráticas.

Quanto às notícias, vimos que elas se dividem entre aquelas que denunciam a ameaça antidemocrática e aquelas que sustentam o discurso do jornal em defesa 
dos valores democráticos. Nessa polarização entre os dois discursos, destacam-se, entre os democráticos, as figuras do Congresso Nacional, do Presidente Mazzilli, do povo e do Exército e, entre os antidemocráticos, as figuras de Carlos Lacerda, Ademar de Barros e João Goulart. Do ponto de vista passional, entendemos que as notícias reforçam a construção da inquietude e do temor diante dos desdobramentos do movimento político em curso naquele momento.

Em suma, o cenário passional construído pela primeira página do Correio da Manhã da edição de 3 de abril pode ser definido assim:

- A disposição do sujeito apaixonado: o jornal e seu leitor experimentam a indignação e a inquietude (atos de violência contra as instituições democráticas) e a desconfiança e o temor (a iminência da instalação de um regime totalitarista de direita);

- O sujeito desencadeador da paixão: Carlos Lacerda, Ademar de Barros e parte do movimento "revolucionário";

- Os motivos que suscitam a paixão: atos de violência da polícia da Guanabara e pressões sobre o Congresso Nacional exercidas por Carlos Lacerda e Ademar de Barros, para realização imediata da eleição do novo Presidente do Brasil.

No que diz respeito ao discurso d'O Globo, vimos que irrompe de sua primeira página o discurso "revolucionário", uma vez que o jornal não só reitera seu posicionamento favorável à derrubada de João Goulart como reproduz o discurso da demonização do comunismo e glorificação das Forças Armadas, dos símbolos da Pátria, da tradição e da família. Vejamos, neste momento, as paixões que emergem dessa primeira página e se associam a esse discurso "revolucionário".

Dentro da cena genérica esperada pelo editorial, o diário $O$ Globo instala-se em seu enunciado como o orador de seu discurso, ao mesmo tempo em que instala a opinião pública como o seu auditório, apresentando ao seu assentimento a tese de que o Congresso Nacional deve aprovar uma "lei de defesa do Estado", a qual teria o objetivo de combater a "orientação demagógica, desleal e subversiva do Govêrno demitido". O jornal adota a estratégia argumentativa de unir as figuras do orador e do auditório para dirigir sua argumentação a um terceiro, o qual se torna o auditório privilegiado desse editorial. Em outros termos, o editorial recorre à imagem da opinião pública para ampliar a autoridade do jornal sobre a tese encaminhada ao assentimento do Congresso Nacional. Todavia essa argumentação não pode ser 
vista como uma negociação de pontos de vista ou como a imagem da ponte que visa a dirimir as diferenças entre as partes etc., pois a natureza dessa argumentação d'O Globo não é a do convencimento, mas sim a da persuasão pelo constrangimento.

O Globo atribui-se a imagem de "democrata" e se alinha às Forças Armadas e à aprovação popular, arrogando para si o direito de pressionar o Congresso Nacional a legitimar a "revolução". Essa pressão manifesta-se não apenas por meio da enunciação deôntica do editorial, que diz o que os congressistas devem fazer, mas principalmente por meio de um conjunto articulado de paixões que culminam na da construção do pathos discursivo, tais como o medo, a indignação, o júbilo e a esperança.

O Globo, ao pressionar o Congresso Nacional a legitimar a "revolução", assume que o movimento político não está concluído e justifica tal obrigação parlamentar em razão da "ameaça comunista" subsistente, o que é corroborado pela projeção da paixão do medo, que pode ser experimentado pelo leitor do editorial "A vez do Congresso" em enunciados tais como:

(12)[...] não se tivesse dado conta da gravidade da situação.

(13)MAS NINGUÉM se iluda. O simples afastamento do Sr. João Goulart não resolverá os problemas brasileiros.

(14)Está evidenciado, pelo que vinha ocorrendo no País, que as instituições não se encontram devidamente protegidas contra a subversão e a penetração vermelha.

(15) É URGENTE que o Congresso vote uma lei de defesa do Estado que nos ponha a coberto da repetição de situações semelhantes à que agora foi exterminada pela Fôrças Armadas.

(16)Tão pesados e difíceis são os problemas a enfrentar de imediato que não seria possível admitir soluções provisórias e espertas.

(17)Necessita agir bem e depressa, até mesmo para que o povo e as Fôrças Armadas não venham a pensar que caíram num Primeiro de Abril.

O Globo também pressiona o Congresso Nacional por meio da provocação e da denúncia generalizada, acusando os congressistas de agirem de acordo com os interesses eleitorais. Diante do medo incutido pela "ameaça comunista", a conduta denunciada pelo jornal desperta no leitor o sentimento de indignação contra deputados e senadores, o que os pressiona a agir da maneira como incitada pelo 
jornal. Despertam a indigação e movem a opinião pública contra o Congresso Nacional enunciados como:

(18)Não saíram elas de seus quartéis, expondo-se aos riscos de uma guerra fratricida e submetendo-se ao inevitável constrangimento que Ihes provoca a intervenção no processo político, para verem, em seguida, o movimento amesquinhado pelos políticos preocupados somente com seus interêsses eleitorais.

(19)Avultado êrro cometeriam os deputados e senadôres se pensassem, a altura dos acontecimentos, em cumprir essa magna obrigação na base da barganha e dos compromissos políticos.

(20)Outro êrro praticariam êles se imaginassem constituir um govêrno provisório e sem maiores responsabilidades.

(21)É imprescindível que o Congresso não decepcione os democratas nem incorra em erros que venham a servir aos comunistas ora em debandada.

É interessante que, apesar da presença das paixões do medo e da indignação, o discurso d'O Globo apresenta-se num tom eufórico, pois inflama seu leitor com as paixões do júbilo pela "vitória" contra João Goulart e da esperança na transformação do Brasil que é prometida pelo discurso do movimento "revolucionário".

(22)A vitória do movimento em tão poucas horas, com o mínimo de sacrifício e práticamente sem derramamento de sangue, enche de entusiasmo os democratas, que se entregam a transportes de alegria.

(23)PRECISA O CONGRESSO ter uma inspiração de grandeza e colocar na Chefia da Nação quem mereça a confiança de todos os setores democráticos, podendo realizar, em consequência, um govêrno fortalecido por amplo apoio parlamentar.

(24)Um nome militar, por exemplo. Do gabarito dos ilustres comandantes do movimento vitorioso.

(25)Não deve perder essa chance, pois, em última análise, foi para a sua defesa, para a defesa do que êle representa, como expressão do regime democrático, que as Fôrças Armadas se puseram em marcha, o povo enfrentou a violência e tôda a Nação viveu um período de sofrimento e angústia, finalmente transformado em dias de luz e esperança.

Essas quatro paixões - o medo, a indignação, o júbilo e a esperança associam-se aos valores "democráticos" propugnados pelo jornal O Globo, os quais são baseados nos símbolos patrióticos, na tradição da família, na crença em Deus, 
nas Forças Armadas. Os valores que sustentam esse discurso do editorial d'O Globo são reforçados pelas fotos-legendas, que reforçam e potencializam os valores, as paixões e o tom eufórico manifestado pelo editorial, atribuindo esses traços ao todo da primeira página, cuja manchete e cuja foto-manchete homogeneízam o sentido do todo da página com o seu tom eufórico ao midiatizar o triunfo dos "revolucionários" na Marcha da Família, Com Deus Pela Liberdade.

Sintetizando, o cenário passional da primeira página d'O Globo é o seguinte:

- A disposição do sujeito apaixonado: o jornal e seu leitor experimentam o medo (o retorno dos comunistas), a indignação (os interesses eleitorais dos deputados e senadores), o júbilo (a vitória sobre João Goulart) e a esperança (recuperação da economia brasileira e da ordem política);

- O sujeito desencadeador das paixões benevolentes: o povo, as Forças Armadas e o novo governo;

- O sujeito desencadeador das paixões malevolentes: João Goulart e seus aliados comunistas, e parlamentares que agem movidos por interesses eleitorais;

- Os motivos que suscitam a paixão: a instabilidade econômica e política do País.

Ao cotejar as primeiras páginas desses dois jornais, vemos cenários passionais e cenografias bem distintas.

O leitor do Correio da Manhã é levado a experimentar a indignação e a inquietude devido aos atos de violência promovidos pela polícia de Carlos Lacerda contra as instituições democráticas e às pressões e ameaças de Ademar de Barros ao Congresso Nacional para a imediata eleição do novo presidente, bem como a desconfiança e o medo devido à iminente instalação de um regime totalitarista de direita. À cenografia do duelo e do terror, soma-se o cenário passional do medo, construindo, assim, uma visão aterrorizante do mundo, especialmente da cena política, e imprimindo no espírito do leitor a apreensão ou o desejo de evitar que algo desagradável aconteça.

Por sua vez, o leitor do d'O Globo é levado a sentir medo do retorno comunista, indignação pelos deputados e senadores descomprometidos com a "revolução", o júbilo pela vitória sobre João Goulart e a esperança na redemocratização do País, paixões que se somam à cenografia do triunfo e que juntas persuadem o leitor a não apenas compreender que a "vitória" não está 
completa, mas a aceitar todas as medidas que forem propostas para o efetivo sucesso da "revolução".

Em matéria de ethos, é possível notar que ambos os jornais diminuem a euforia diante dos fatos. O tom eufórico mas desconfiado da edição de 2 de abril do Correio da Manhã desce um pouco, passando à desconfiado e temeroso, enquanto o tom d'O Globo desce de totalmente eufórico (2 de abril) para eufórico mas levemente temeroso. Em outros termos, não lhes basta construir a imagem do jornal que confia plenamente nos valores que eles defendem, pois é preciso desqualificar o Outro, incutindo no espírito do leitor a apreensão diante dos perigos representados por esse Outro e, consequentemente, o desejo de repelir esse Outro.

Neste momento da análise é importante dizer, novamente, que o ethos do jornal corresponde ao modo de ser e de se comportar no mundo jornalístico num dado contexto sócio-histórico.

O contexto sócio-histórico do movimento político de 1964 põe em cena a polêmica entre "revolucionários" e "antigolpistas", que aparece nos discursos jornalísticos em tela como uma polêmica entre democráticos e antidemocráticos, pois até aquele momento o Correio da Manhã ainda não havia rompido totalmente com o movimento "revolucionário", tomando-o como golpista. Nessa polêmica, cada jornal traduz o que é e quem é democrático e antidemocrático de acordo com a doxa de sua comunidade argumentativa ou as categorias semânticas da formação discursiva nas quais se inscrevem. Assim:

- O Correio da Manhã denuncia os atos antidemocráticos de Carlos Lacerda e de Ademar de Barros, enquanto $O$ Globo silencia esses acontecimentos;

- O Correio da Manhã delega voz ao ex-presidente, obedecendo ao princípio jornalístico da imparcialidade, enquanto $O$ Globo silencia seu discurso e desqualifica sua imagem;

- O Correio da Manhã destina quase um terço da primeira página, para destacar a posse do então presidente da Câmara dos Deputados Raniere Mazzilli na Presidência da República, valorizando a Constituição brasileira, enquanto $O$ Globo dá destaque de rodapé de página para Mazzilli e, em seu editorial, afirma que o Congresso Nacional não pode esperar o prazo determinado pela Constituição para eleger o novo presidente; 
- O Correio da Manhã mostra-se, em seu noticiário, preocupado com as prisões e as arbitrariedades que começam a despontar após a derrubada de João Goulart, enquanto $O$ Globo preocupa-se em mostrar o triunfo da família, da tradição e dos generais, destacando em sua foto-manchete a Marcha da Família com Deus pela Liberdade;

- O Correio da Manhã deixa entrever a tensão que envolve os desdobramentos do movimento político ao manifestar em sua primeira página paixões como a indignação, a inquietude, a desconfiança e o temor, enquanto $O$ Globo exalta a festa dos generais e a alegria da família por meio das paixões do júbilo e da esperança, que só não atingiram a plenitude, pois o "comunismo" não foi ainda exterminado.

Considerando o contexto sócio-histórico, a finalidade jornalística, o posicionamento discursivo perante o movimento político em curso, a cenografia projetada pela primeira página, o cenário passional e a axiologização dos valores na polêmica entre democráticos e antidemocráticos, é possível depreender que o Correio da Manhã reitera a construção do ethos do jornal ético e imparcial no sentido de defender as regras do jogo democrático, enquanto $O$ Globo produz o ethos do jornal antiético, pois, totalmente comprometido com um segmento da sociedade, defende a suspensão das regras do jogo democrático. E isso, parece-nos, ser crucial para a determinação da diferença entre os ethé jornalísticos do Correio da Manhã e d'O Globo em suas primeiras páginas de 3 de abril de 1964.

Assim, podemos dizer que o Correio da Manhã constrói um ethos democrático, enquanto $O$ Globo, ao tentar atribuir a si a imagem de "democrata" que luta pelo povo, mas se mostra avesso às regras do jogo democrático, constrói, de fato, um ethos demagógico.

Salientamos que os efeitos do ethos no discurso jornalístico não visam somente à conquista da adesão do leitor no momento de enunciação dos discursos. A construção do ethos age sobre a memória discursiva, atualizando não apenas posicionamentos discursivos, mas também maneiras de ser e de se comportar numa dada sociedade. Isso quer dizer que determinados modos de comportamento, que legitimam determinados discursos, são reproduzidos ad infinitum, preterindo os argumentos que fundamentam o ponto de vista defendido. Esse é o auge da retórica da imagem de si. 
O ethos demagógico construído pelo discurso d'O Globo suscita o corpo enunciante também demagógico e determina a construção de um anti-ethos não demagógico, que corresponde à imagem de seu anti-sujeito. No que tange à incorporação do ethos pelo coenunciador, é preciso dizer que o ethos demagógico d'O Globo mais o seu anti-ethos não demagógico captam o imaginário do leitor, convidando-o a fazer parte desse corpo de pessoas que, em nome de valores morais, não veem problemas na violação dos direitos previstos pelas regras criadas pela própria sociedade da qual esse indivíduo faz parte.

Por outro lado, o ethos democrático do Correio da Manhã suscita um corpo enunciante democrático e determina a construção de um anti-ethos não democrático (tirano, demagógico etc.), que corresponde à imagem de seu anti-sujeito. A oposição entre esse ethos e esse anti-ethos capta o imaginário do leitor, convidando-o a fazer parte de um corpo de pessoas que acreditam no estado de direito.

Portanto, podemos concluir que o ethos demagógico que emerge da primeira página d'O Globo legitima um discurso jornalístico "revolucionário", enquanto o ethos democrático que irrompe da primeira página do Correio da Manhã legitima a enunciação de um discurso progressista que tenta escapar à polarização entre "revolucionários" e "antigolpistas", entre "reacionários" e "reformistas", enfim, entre "capitalistas" e "comunistas". 


\subsection{Análise das primeiras páginas das edições de 10 de abril}

As edições de 10 de abril voltam-se para o acontecimento do Ato Institucional, editado em 9 de abril de 1964. No Quadro 11, identificamos os títulos das primeiras páginas do Correio da Manhã e d'O Globo de 10 de abril de 1964:

Quadro 11 - Títulos das capas do Correio da Manhã e d'O Globo de 10.04.1964

\begin{tabular}{|c|c|c|c|c|}
\hline \multirow{2}{*}{$\begin{array}{l}\text { FINALI } \\
\text { DADE }\end{array}$} & \multicolumn{2}{|c|}{ Correio da Manhã } & \multicolumn{2}{|r|}{ O Globo } \\
\hline & Gênero & Título & Gênero & Título \\
\hline \multirow{2}{*}{ 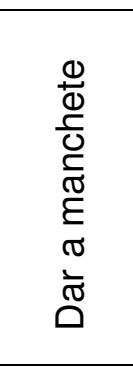 } & Manchete & $\begin{array}{l}\text { BRASIL SOB NÔVO } \\
\text { REGIME }\end{array}$ & $\begin{array}{l}\text { Chapéu } \\
\text { da página }\end{array}$ & $\begin{array}{c}\text { O Marechal Eurico Dutra } \\
\text { Resolveu Retirar a Sua } \\
\text { Candidatura (TEXTO NA 6a } \\
\text { PÁGINA) }\end{array}$ \\
\hline & & & Manchete & $\begin{array}{l}\text { CASSADOS OS MANDATOS } \\
\text { DE } 40 \text { PARLAMENTARES E } \\
\text { SUSPENSOS DIREITOS } \\
\text { POLÍTICOS DE } 58 \text { PESSOAS }\end{array}$ \\
\hline$\frac{\bar{\varpi}}{. \overline{\frac{\partial}{0}}}$ & & & Editorial & O Nôvo Presidente \\
\hline \multirow{4}{*}{ 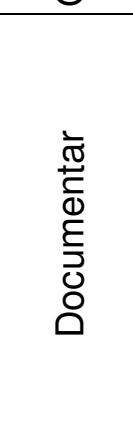 } & $\begin{array}{c}\text { Foto- } \\
\text { legenda }\end{array}$ & Responsabilidade & $\begin{array}{c}\text { Foto- } \\
\text { legenda }\end{array}$ & (sem título) \\
\hline & \begin{tabular}{|c|} 
Nota \\
comen-tário \\
relatado
\end{tabular} & Ato Institucional & $\begin{array}{l}\text { Foto- } \\
\text { legenda }\end{array}$ & (sem título) \\
\hline & & & $\begin{array}{c}\text { Foto- } \\
\text { legenda }\end{array}$ & (sem título) \\
\hline & & & $\begin{array}{l}\text { Foto- } \\
\text { legenda }\end{array}$ & (sem título) \\
\hline \multirow{6}{*}{$\begin{array}{l}\frac{\pi}{0} \\
\frac{.0}{0} \\
\frac{0}{2}\end{array}$} & Notícia & (contígua à manchete) & $\begin{array}{l}\text { Notícia } \\
\text { com } \\
\text { chamada }\end{array}$ & $\begin{array}{c}\text { LEITÃO DA CUNHA DIZ QUE } \\
\text { O BRASIL NÃO PACTUARÁ } \\
\text { COM O COMUNISMO NA } \\
\text { AMÉRICA LATINA }\end{array}$ \\
\hline & Notícia & $\begin{array}{l}\text { Ex-deputados vão para } \\
\text { prisão comum }\end{array}$ & $\begin{array}{l}\text { Notícia } \\
\text { com } \\
\text { chamada }\end{array}$ & $\begin{array}{l}\text { Nove Governadores do } \\
\text { Nordeste Trouxeram Seu } \\
\text { Apoio a Castelo Branco }\end{array}$ \\
\hline & Notícia & $\begin{array}{l}\text { JG, JQ E PRESTES: } \\
\text { DIREITOS CASSADOS }\end{array}$ & $\begin{array}{l}\text { Notícia } \\
\text { com } \\
\text { chamada }\end{array}$ & $\begin{array}{l}\text { Ante a Derrota Brizzola } \\
\text { Raspou os Cofres da Caixa } \\
\text { Econômica do R.G. do Sul }\end{array}$ \\
\hline & Notícia & $\begin{array}{l}\text { CONGRESSAO } \\
\text { ELEGERÁ O NÔVO } \\
\text { PRESIDENTE } \\
\end{array}$ & Notícia & $\begin{array}{c}\text { ATO INSTITUCIONAL } \\
\text { GARANTE ARMAS PARA A } \\
\text { DEMOCRACIA }\end{array}$ \\
\hline & Notícia & Asilados em embaixadas & Notícia & $\begin{array}{c}\text { CONVOCADO O } \\
\text { CONGRESSO PARA } \\
\text { ELEGER AMANHÃ O } \\
\text { PRESIDENTE E O VICE }\end{array}$ \\
\hline & Notícia & $\begin{array}{c}\text { Presidente será eleito no } \\
\text { sábado }\end{array}$ & Chamada & $\begin{array}{l}\text { Mazzilli Dirige Manifesto à } \\
\text { Nação (Texto na 6. }{ }^{\text {a }} \text { Página) }\end{array}$ \\
\hline
\end{tabular}




\subsubsection{As manchetes e as fotos-manchetes}

Em primeiro lugar, é interessante notar que as manchetes das edições do dia 10 de abril do Correio da Manhã e d'O Globo midiatizam o mesmo acontecimento dentro do movimento político de 1964, a promulgação do Ato Institucional (doravante $\mathrm{Al}$ ), mas o fazem de maneira tão distinta que parecem não tratar do mesmo acontecimento, pois o Correio da Manhã, com a manchete "Brasil sob nôvo regime", focaliza a edição do $\mathrm{Al}$, ao passo que $\mathrm{O}$ Globo, com a manchete "Cassados os mandatos de 40 parlamentares e suspensos direitos políticos de 58 pessoas", destaca não o $\mathrm{Al}$, mas sim as suas primeiras consequências. Em outras palavras, um jornal preocupa-se com o novo regime político em instalação e o outro jornal empenha-se em divulgar os resultados obtidos imediatamente após a apresentação do $\mathrm{Al}$; enquanto um quer compreender o novo regime, o outro quer divulgar a "eficácia" do novo regime; de um lado, questiona-se, de outro lado, justifica-se o regime.

O discurso que emerge da manchete do Correio da Manhã atribui à promulgação do $\mathrm{Al}$ um sentido bem definido no que diz respeito à nova situação política brasileira, pois, para o jornal, o Al instaura um novo regime político no Brasil. Por sua vez, O Globo apresenta uma manchete com períodos compostos, detalhando os fatos políticos e seus atores e, redigida na voz passiva, explicita os atores que sofrem as ações de "cassar" e de "suspender", mas não explicita os atores que agem, ou seja, não revela em letras garrafais que os chefes militares e 0 novo regime político cassaram mandatos de 40 parlamentares e suspendeu direitos políticos de 58 pessoas. É interessante que a manchete d'O Globo, ao se referir ao regime militar, recorre a uma construção sintática que diminui o tom de seu discurso, apresentando, aliás, um tom muito distinto daquele empregado nas edições de 2 e 3 de abril, quando acusava João Goulart e festejava sua derrubada.

Em ambos os jornais, cada foto-manchete mantém uma relação de complementaridade com sua manchete, pois os sentidos produzidos por esses dois gêneros jornalísticos coadunam-se para formar um todo de sentido que, devido às características da manchete, homogeneíza os sentidos das primeiras páginas de cada jornal.

Como o objetivo de nossa análise não se limita a examinar os elementos de composição de uma fotografia e tampouco as concebe apenas como um signo 
referente, é preciso dizer que, nas primeiras páginas do Correio da Manhã e d'O Globo de 10 de abril de 1964, as imagens fotográficas de suas fotos-manchetes manifestam verbo-visualmente os discursos produzidos verbalmente por suas manchetes a respeito do acontecimento em torno da assinatura do Al pelos generais Costa e Silva, Augusto Rademaker e Corrêa de Melo (Correio da Manhã) ou do acontecimento em torno da cassação dos primeiros mandatos políticos promovidos pelo $\mathrm{Al}(\mathrm{O}$ Globo). Vejamos as imagens fotográficas em questão:

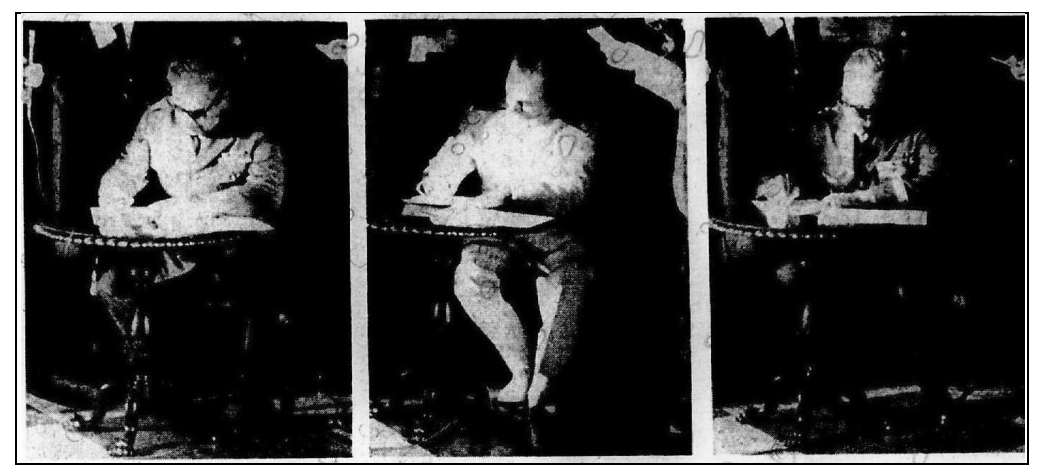

Figura 15 - Fotografia da foto-manchete do Correio da Manhã, de 10.04.1964

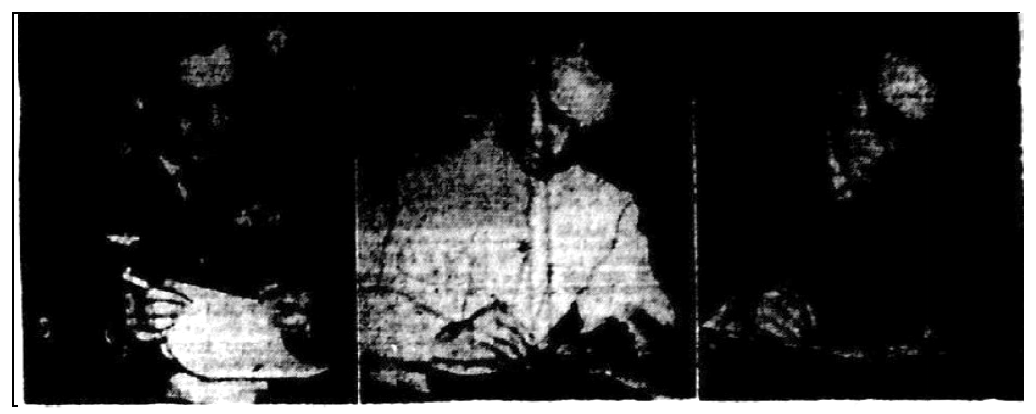

Figura 16 - Fotografia da foto-manchete d'O Globo, de 10.04.1964

É relevante notar que os dois jornais promoveram recortes parecidos, dispondo os três generais lado a lado numa mesma imagem como se estivessem assinando o Al ao mesmo tempo. Todavia o enquadramento de cada fotografia difere.

Embora o evento tenha ocorrido no salão nobre do Ministério da Guerra, o discurso do Correio da Manhã projeta por meio dessa fotografia (Figura 15) a imagem do corpo inteiro de três homens fardados, sentados a uma pequena mesa e com seus corpos inclinados sobre os papéis, na posição de quem escreve. É intrigante a maneira como o Correio da Manhã projeta a imagem desses três generais assinando o Al e, assim, instaurando o novo regime político, porque os 
generais são representados de corpo inteiro, mas o enquadramento os deixa pequenos, bem como a mesa sobre a qual assinam o documento também é pequena. Esse enquadramento permite-nos inferir que há uma avaliação do Correio da Manhã a respeito desse acontecimento. Poderíamos arriscar a dizer que o jornal, ao representar os elementos da fotografia de forma diminuta, produz um discurso disfórico sobre o $\mathrm{Al}$, distiguindo-se da euforia caracterizante do discurso "revolucionário".

No que toca ao discurso d'O Globo, este constrói a cena da assinatura do Al, recorrendo ao enquadramento fotográfico em plano americano (Figura 16). Nesse enquadramento, as formas fotogradas preenchem o fundo da imagem, a pequena mesa é apagada, o busto e mão que assina o documento são focalizados. Assim, o jornal projeta uma imagem altiva dos generais, mantendo seu tom eufórico sobre 0 movimento político de 1964 e assumindo, portanto, o discurso "revolucionário". 


\subsubsection{As fotos-legendas e a nota comentário relatado}

As fotos-legendas d'O Globo documentam acontecimentos alheios à cobertura do movimento político, todavia reportam-se a elementos valorizados no discurso "revolucionário", pois esse jornal, ao compor a primeira página com fotoslegendas que documentam a visita do Papa Paulo VI a um cárcere, o lançamento de um submarino nuclear pelos EUA, o funeral do general Mac Arthur em Washington e um iceberg rebocado por uma embarcação estadunidense, midiatiza a caridade cristã personalizada na figura do Papa, bem como a ufania pelo país símbolo do modo de vida capitalista e da luta contra o comunismo. Assim, o efeito de sentido gerado pelas fotos-legendas na primeira página da edição de 10 de abril de 1964 d'O Globo é o de valorizar positivamente a imagem da Igreja Católica e do bloco capitalista, construindo, portanto, um discurso convergente ao discurso do movimento "revolucionário" de 1964.

De outro lado, a primeira página do Correio da Manhã de 10 de abril não recorre ao gênero foto-legenda, mas publica uma nota comentário relatado que ocupa quase dois terços da página, simulando a enunciação do Comando Supremo da Revolução que edita o Ato Institucional. O Al é composto de duas partes: uma carta endereçada à Nação com o objetivo de justificar e legitimar a edição do Al e o próprio Ato em 11 artigos.

Em primeiro lugar, o exórdio dessa carta introdutória ao Al busca captar a benevolência de seu leitor - instalado em seu enunciado na figura da "Nação" - por meio de uma enunciação profética, pois apresenta o movimento como o provedor de um novo futuro ao País. No sentido de legitimar o conceito do movimento político e, com base nisso, justificar as medidas do Ato, a carta tem a finalidade de convencer o seu leitor de que o movimento político é "uma autêntica revolução":

\footnotetext{
É indispensável fixar o conceito do movimento civil e militar que acaba de abrir ao Brasil uma nova perspectiva sôbre o seu futuro. O que houve e continuará a haver neste momento, não só no espírito e no comportamento das classes armadas, como na opinião pública nacional, é uma autêntica revolução (ATO INSTITUCIONAL. In: CORREIO DA MANHÃ, 1964c).
}

O discurso "revolucionário" dos generais busca construir sua legitimidade, recorrendo ao argumento do apoio popular. Os generais reproduzem em seus discursos as manifestações populares, tais como a da Marcha da Família com Deus pela Liberdade. Todavia, é preciso lembrar que esse discurso apaga a orientação 
ideológica dos "populares" que estavam na marcha, a qual pudemos mostrar na análise da primeira página d'O Globo de 3 de abril de 1964, assim como escamoteia as estratégias empregadas pelos grupos de ação do IPES/IBAD para controlar a imprensa. O que se nota nesse discurso "revolucionário" é que tal estratégia discursiva de apagamento de discursos outros está voltada para o silenciamento do discurso "antigolpista". No segundo parágrafo da carta introdutória ao Al, o termo "golpe de estado", entre outros, aparece apagado pela expressão "outros movimentos armados":

A revolução se distingue de outros movimentos armados pelo fato de que nela se traduz, não o interêsse e a vontade de um grupo, mas o interêsse e a vontade da Nação (ATO INSTITUCIONAL. In: CORREIO DA MANHÃ, 1964c) [grifo nosso].

Dreifuss (1981, p. 162), num estudo notório e irrepreensível sobre a organização desse movimento político para a conquista do poder, já nos mostra que o objetivo da campanha de desestabilização e derrubada do governo João Goulart é a "transposição do poder privado dos interesses multinacionais e associados para o governo público do Brasil". Com base nessa obra, podemos afirmar que os interesses multinacionais estão ligados a determinados grupos sociais, mas não à nação brasileira, como pretende fazer crer o discurso "revolucionário", o qual, ao construir seu discurso com base na inversão entre o que é e o que parece ser, apresenta-se como um discurso mentiroso ou, de acordo com a terminologia política, um discurso demagógico. Vejamos mais um trecho em que o discurso "revolucionário" recorre a esse tipo de argumento:

Os chefes da revolução vitoriosa, graças à ação das Fôrças Armadas e ao apoio inequívoco da Nação, representam o Povo e em seu nome exercem o Poder Constituinte, de que o Povo é o único titular (Ibidem).

Os objetivos do Al apresentados nessa carta introdutória são sustentados pelos mesmos valores presentes no discurso d'O Globo, tais como a restauração da ordem, a reconstrução da economia e o banimento do comunismo:

O Ato Institucional que é hoje editado [...] se destina a assegurar ao nôvo Govêrno a ser instituído, os meios indispensáveis à obra de reconstrução econômica, financeira, política e moral do Brasil (Ibidem). 
Os generais justificam a edição do Al e da "revolução", argumentando que "os processos constitucionais" não bastavam para "destituir o Govêrno" alinhado ao comunismo internacional:

O presente Ato Institucional só poderia ser editado pela revolução vitoriosa [...]. Os processos constitucionais não funcionaram para destituir o Govêrno, que deliberadamente se dispunha a bolchevizar o país.

Em outras palavras, já que o governo João Goulart não poderia ser deposto por meio de um impeachment, que, segundo o Dicionário Houaiss da Língua Portuguesa, consiste num "processo político-criminal instaurado por denúncia no Congresso para apurar a responsabilidade, por grave delito ou má conduta no exercício de suas funções, do presidente da República [...]", a sua destituição seria promovida por meio de uma "revolução", ou seja, uma articulação política e militar organizada para derrubar o governo empossado por meio de eleições diretas para presidente e para vice-presidente. $O$ que podemos compreender com base nas análises apresentadas é que o Ato Institucional não parece se tratar de uma ação democrática nem moral, tal como aparece no discurso "revolucionário", encampado inclusive pelo discurso jornalístico d'O Globo.

É interessante notar como o discurso da radicalização aparece no discurso dos generais por meio da negação polêmica (cf Maingueneau, 1997 [1987], p. 84), porque, ao dizer "não pretendemos radicalizar", os generais rejeitam o discurso do enunciador do discurso pressuposto "os generais vão radicalizar":

Para demonstrar que não pretendemos radicalizar o processo
revolucionário, decidimos manter a Constituição de 1946, limitando-nos a
modificá-la, apenas, na parte relativa aos poderes do presidente da
República, a fim de que êste possa cumprir a missão de restaurar no Brasil
a ordem econômica e financeira e tomar as urgentes medidas destinadas a
drenar o bolsão comunista, cuja purulência já havia infiltrado não só na
cúpula do Govêrno como nas suas dependências administrativas (Ibidem)
[grifo nosso].

Sobretudo, reproduz-se, nessa nota comentário relatado o discurso que atribui a imagem do inimigo ao governo deposto de João Goulart, qualificado como purulento, infeccioso, para, em nome da vitória sobre esse inimigo, se justificar o desrespeito à Constituição, os atos de violência, a arbitrariedade das prisões efetuadas já nos primeiros momentos da deposição de João Goulart, enfim justificar a edição do Ato Institucional, o qual dá plenos poderes ao Presidente da República. 
Esse é o discurso dos generais que emerge da publicação do Al, ou seja, é o discurso que emerge do enunciado que se manifesta por meio da nota comentário relatado da primeira página do Correio da Manhã, entretanto é preciso compreender qual é o sentido que se constrói nesse jogo entre enunciado e enunciação, para, então, analisar o discurso do Correio da Manhã sobre a promulgação do Al.

Para tanto, é preciso retomar os sentidos já depreendidos da manchete e da foto-manchete, bem como analisar as notícias, observando os acontecimentos construídos e a relação entre os discursos citantes dos jornais e os discursos citados que se manifestam nas notícias. 


\subsubsection{As notícias}

Procederemos à análise das notícias apresentadas nas primeiras páginas de ambos os jornais, observando como os acontecimentos construídos, nessa página, participam como argumentos que reforçam o ponto de vista defendido por cada jornal em sua primeira página.

Comparada à edição de 3 de abril, a composição da primeira página da edição de 10 de abril concede menos espaço às notícias, destinando-lhes aproximadamente um terço da página. Já $O$ Globo destina pouco espaço para suas notícias, recorrendo, principalmente, às notícias com chamada de capa para aprofundamento.

Recuperando os dados do Quadro 6, o Correio da Manhã publica uma notícia contígua à manchete "Brasil sôb novo regime" (texto 2) e mais cinco notícias cujos títulos são:

- "Ex-deputados vão para prisão comum" (texto 3);

- “JG, JQ e Prestes: direitos cassados" (texto 4);

- "Congressao elegerá o nôvo presidente" (texto 5);

- "Asilados em embaixadas" (texto 8);

- "Presidente será eleito no sábado" (texto 9).

$\mathrm{Na}$ notícia contígua à manchete (texto 2), o Correio da Manhã relata o acontecimento da assinatura do Al de maneira distanciada, pois não lança apreciações valorativas sobre o Al e delega voz aos atores discursivos responsáveis pelo $\mathrm{Al}$, introduzindo tais vozes por meio de verbos dicendi próximos à neutralidade. Vejamos a lead:

Às $17 \mathrm{~h} 45 \mathrm{~m}$ de ontem os três ministros militares assinaram o Ato
Institucional, no salão nobre do Ministério da Guerra, dando nôvo regime ao
País - instalando uma nova República, como disse o general Artur da Costa
e Silva - mas respeitando a Constituição de 1946 e as Constituições
estaduais, com as modificações introduzidas no diploma ontem proclamado.
O Ato Institucional, segundo seu têxto, já está em vigor desde ontem
(CORREIO DA MANHÃ, $1964 c)$ [grifos nossos].

Os trechos grifados acima correspondem à presença do discurso citado no lead da notícia e revelam que o Correio da Manhã concorda com a afirmação de que - Brasil entra num novo regime, todavia mostra que não adere ao discurso 
"revolucionário", pois se distancia da apreciação "uma nova República", marcando-a como pertencente ao discurso do general Costa e Silva.

É interessante notar como o discurso do Correio da Manhã mostra seu interesse pela compreensão da edição desse Ato Institucional, pois, ao invés de mostrar os resultados do Ato, como o faz O Globo, o Correio da Manhã reproduz as explicações sobre a assinatura do Al, delegando voz ao ministro da Guerra, conforme os trechos grifados no excerto abaixo:

$\mathrm{Na}$ tarde de ontem, perante grande número de oficiais generais, almirantes e brigadeiros, o ministro da Guerra deu explicações sôbre a assinatura do Ato Institucional. Declarou que, naquele momento, seria editado o diploma em nome da revolução vitoriosa e dos seus chefes. Em face da gravidade dos últimos acontecimentos, frisou, resolveram os chefes das Fôrças Armadas tomar uma decisão definitiva para que no Brasil voltasse a reinar 0 regime da lei e da ordem; para assegurar êsse regime ora iniciado, foi preciso baixar o Ato Institucional que, por delegação do "Comando Revolucionário", deu ao conhecimento do público. A seguir o general Sizeno Sarmento, chefe do gabinete do ministro da Guerra, leu através de uma cadeia de emissoras de rádio e televisão, o Ato Institucional (CORREIO DA MANHÃ, 1964c) [grifos nossos].

Essa notícia destaca, ainda, como as Forças Armadas pretendem relacionarse com a imprensa. À primeira vista, parece que haverá uma convivência pacífica, porém é reveladora a construção da fissura entre o discurso citante do jornal e o discurso citado do general entrevistado, a qual ocorre por meio da abertura de aspas no curso de um discurso indireto, sobretudo porque a primeira palavra após as aspas é a adversativa "mas". Abaixo, os trechos grifados correspondem à voz do discurso citado. Vejamos:

O general Justino Alves Bastos, comandante do IV Exército, declarou aos repórteres que as Fôrças Armadas vão manter a imprensa livre, "mas é preciso que os instrumentos de divulgação colaborem, como vêm colaborando". E mais: "Em Recife a imprensa tem atuado muito bem, não sendo forçada a nenhuma restrição contra suas acões. Reunimos todos os iornalistas e fizemos apelos nesse sentido. Os profissionais de imprensa conduzem-se nos princípios da ordem e do bem comum" (CORREIO DA MANHÃ, 1964c) [grifos nossos].

Do excerto acima, é preciso compreender qual é o sentido do verbo "colaborar" nesse discurso citado. Parece patente que "colaborar" significa não ir contra os objetivos da "revolução", não inflamar a população contra o novo regime, não questionar a natureza e as consequências da edição desse Ato Institucional. Basta observar a declaração do mesmo general que é enunciada no segundo período do parágrafo supracitado: "Em Recife a imprensa tem atuado muito bem, 
não sendo forçada a nenhuma restrição contra suas ações". Se esse enunciado é o que está posto, podemos entender que o seu pressuposto é que, se a imprensa não atuar muito bem, será forçada a restrições contra suas ações, isto é, contra o seu direito e dever de informar o cidadão.

O Correio da Manhã constrói um enunciado que apaga a opinião explícita do jornal perante o acontecimento da promulgação do Al, todavia, no nível da enunciação, esse aparente distanciamento revela um posicionamento, no mínimo, de desconfiança perante o movimento "revolucionário". O que nossas análises tentam mostrar é que o discurso do Correio da Manhã distancia-se do discurso "revolucionário", diferentemente d'O Globo, que, por exemplo, transforma em título de notícia (veja "O Ministro da Guerra Anuncia a Instauração de Uma Nova República"), sem aspas e sem qualquer outra marca de fronteira enunciativa, aquele mesmo enunciado do general Bastos citado pelo Correio da Manhã entre aspas e com o distanciamento que lhe foi possível.

Passemos à análise das notícias transcritas nos textos 3 e 4 , em que 0 Correio da Manhã relata os primeiros efeitos do Al: a prisão de deputados por ações "subversivas" e a cassação dos direitos políticos de dois ex-presidentes e de um exsenador. É interessante notar que o Correio da Manhã faz a referenciação discursiva aos condenados políticos por meio de seus nomes e cargos, porque, ao não thes atribuir o termo "comunista", rechaça o discurso "revolucionário":

Os três ministros militares, ontem mesmo, após a assinatura do Ato
Institucional, resolveram usar de suas novas atribuições: cassaram os
direitos políticos dos srs. João Belchior Marques Goulart, ex-presidente da
República, Jânio da Silva Quadros, também ex-presidente da República, e
Luís Carlos Prestes, ex-Senador da República e chefe do Partido Comunista
Brasileiro [...] (CORREIO DA MANHÃ $1964 c$ ) [grifos nossos].

No texto 5, a notícia focaliza as eleições para Presidente e Vice-presidente do Brasil, de acordo com o novo regime. Destacamos que, nessa notícia, o posicionamento do Correio da Manhã sobre o novo regime manifesta-se um pouco mais explicitamente no fio discursivo.

Sobre o trecho a seguir, cabem duas observações:

[...] A despeito da promulgação, ontem, pelo Comando Revolucionário, do Ato Institucional que cassa mandatos, suprime a vitaliciedade na cátedra e na magistratura e suspende os direitos políticos por um prazo de 10 anos, ao Congresso Nacional restou, apesar de tudo, a competência para eleger o futuro presidente da República [...] (CORREIO DA MANHÃ, 1964c) [grifos nossos]. 
A primeira diz respeito à construção sintática do período. A oração adjetiva restritiva introduzida pela conjunção "que", em "[...] o Ato Institucional que [...]", apresenta como enunciado posto "o Ato Institucional que cassa mandatos, suprime a vitaliciedade na cátedra e na magistratura e suspende os direitos políticos [...]", ou seja, um Ato que vai contra as liberdades democráticas, e como enunciado pressuposto "o Ato Institucional que não cassa mandatos, não suprime a vitaliciedade na cátedra e na magistratura nem suspende os direitos políticos [...]", revelando, portanto, um discurso que concebe um Ato Institucional que deveria ser editado em nome da consolidação da democracia, mas não ao contrário.

A segunda observação é que a expressão "apesar de tudo" atribui às ações do Ato qualidades maléficas, do qual restou apenas uma ação útil à democracia: a eleição do presidente pelo Congresso Nacional. Revela-se, assim, um discurso em que o sentido do Ato Institucional afasta-se do sentido que o Ato possui no discurso "revolucionário", pois deixa entrever que o Al é uma afronta ao estado de direito e ao Congresso Nacional, logo é um entrave à democracia.

O que estamos tentando mostrar desde o começo de nossas análises é que o discurso do Correio da Manhã, apesar de ter sido favorável à deposição de João Goulart, jamais se apresentou como um discurso "revolucionário", entretanto esse discurso - que não é "revolucionário" - começa, ainda que timidamente, a se distanciar dos posicionamentos da "Revolução".

Timidamente, porque, embora critique o Al, o Correio da Manhã leva seu leitor a se satisfazer com a ideia de eleições indiretas para Presidente da República e a acreditar que um civil sairá vencedor de um pleito disputado com mais três generais "revolucionários". Nesse aspecto, parece-nos que as fontes d'O Globo estavam mais afinadas com o novo regime, pois - como veremos - $O$ Globo rechaça a ideia de que haveria divisão entre os militares e aposta na eleição de Castelo Branco para Presidente.

$\mathrm{Na}$ análise da manchete e da foto-manchete, vimos que o Correio da Manhã focaliza a instalação do novo regime político e produz um discurso que se distancia da euforia que caracteriza o discurso "revolucionário". Na análise das notícias, mostramos que o discurso do Correio da Manhã é construído por meio de enunciados que tentam esconder as marcas de sua subjetividade discursiva, salvo algumas poucas marcas reveladoras, produzindo assim o efeito de distanciamento e 
objetividade, o que deixa a enunciação do Correio da Manhã em conformidade com as coerções genéricas do gênero notícia.

Com base nos dados do Quadro 7, destacamos os seguintes títulos das notícias (e suas variantes) d'O Globo:

- Sem título (texto 5);

- "Leitão da Cunha diz que o Brasil não pactuará com o comunismo na América Latina" (texto 6);

- "Convocado o Congresso para eleger amanhã o Presidente e o Vice" (texto 8);

- "Nove Governadores do Nordeste Trouxeram Seu Apoio a Castelo Branco" (texto 10);

- "O Ministro da Guerra Anuncia a Instauração de Uma Nova República" (texto 10);

- “Ante a Derrota Brizzola Raspou os Cofres da Caixa Econômica do R.G. do Sul" (texto 15).

Todos esses textos são pequenas notícias, quando não apenas chamadas de capa para aprofundamento da notícia nas páginas internas. Todavia, entendemos que os títulos que compõem a primeira página são enunciados que estão presentes na construção do sentido dessa página jornalística. É preciso dizer que essa estratégia de composição da primeira página, ao privilegiar os títulos por meio de chamadas de capa e de notícias com chamada de capa, integra o projeto gráficovisual do próprio jornal, que é marcado pela ideologia do flash.

No geral, o conjunto desses títulos revela o posicionamento favorável d'O Globo perante a edição e as consequências do Ato. No texto 5 , seleciona e resume os três primeiros parágrafos do Al. No texto 6, mostra-se preocupado com a "ameaça comunista". No texto 8, relata o acontecimento da convocação feita ao Congresso Nacional para a eleição do presidente e do vice-presidente. No texto 10, o jornal mostra ao leitor que todos os governadores do Nordeste apoiam o general Castelo Branco, logo a "revolução". No texto 11, a notícia com chamada de capa aborda o acontecimento em si, que é o Al, o qual, segundo o Ministro da Guerra e $O$ Globo, inaugura "uma nova República". Com o título "Ato Institucional garante armas para a democracia”, instala-se a cenografia da guerra, na qual os adversários são 
inimigos que devem ser aniquilados com o uso de armas, e não apenas um ponto de vista divergente a ser dissuadido.

Segundo Dreifuss (1981), havia dois anos, no mínimo, que o IPES/IBAD interferia na imprensa, com o objetivo de disseminar a ideologia anticomunista na sociedade brasileira, de modo a construir a imagem de um inimigo público comum e consubstanciá-la na forma do "comunista". Embora o governo de João Goulart seja alinhado ao discurso nacionalista-reformista, conseguiu-se, com a ajuda d'O Globo, atribuir a João Goulart e ao seu governo a imagem do "comunismo", ou seja, a imagem do inimigo.

Estas notícias são exemplos de como, para o discurso "revolucionário" d'O Globo, o regime democrático admite valores tais como "eleição do Presidente e do Vice pelo Congresso", "estado de sítio", "cassação de mandatos legislativos" e "suspensão [...] de direitos políticos", em que se revela a contradição do discurso, uma vez que o regime democrático não admite valores antidemocráticos.

Por fim, as chamadas e as notícias com chamada publicadas na primeira página d'O Globo de 10 de abril não apenas valorizam positivamente o discurso "revolucionário", como também desqualificam os enunciadores do discurso nacionalista-reformista do governo João Goulart, nesse sentido o texto 15 "Ante a Derrota Brizzola Raspou os Cofres da Caixa Econômica do R.G. do Sul" atribui a Leonel Brizzola - governador do Rio Grande do Sul, correligionário e cunhado de João Goulart - a imagem de ladrão sorrateiro.

Em suma, podemos dizer que, se a análise da manchete e da foto-manchete mostrou que $O$ Globo ressalta, euforicamente, os primeiros resultados obtidos pela "revolução" após a edição do Al, a análise das chamadas de capa e das notícias com chamadas de capa mostram como estas constroem o efeito de "real", oferecendo ao leitor "fatos" que comprovam o posicionamento discursivo do jornal. 


\subsubsection{O editorial}

Vimos mostrando como os dois jornais vêm construindo discursivamente o movimento político de abril de 1964 e como esse acontecimento é justificado em nome da "democracia", cujo sentido desliza de discurso para discurso, conforme as crenças e os valores manifestados no discurso de cada jornal. Igualmente, vimos apontando como as formações discursivas ditas "revolucionária" e "antigolpista" penetram nos discursos do Correio da Manhã e d'O Globo, revelando, assim, os seus posicionamentos dentro dessa relação polêmica.

Em 10 de abril, como não houve editorial publicado na primeira página do Correio da Manhã, analisaremos apenas o editorial d'O Globo "O Nôvo Presidente" (Quadro 7, Texto 4).

De início, $O$ Globo estabelece como ponto de partida para a argumentação o fato de que a Nação está ansiosa pela eleição do Presidente e do Vice-Presidente. Constrói, portanto, uma paixão benevolente, ou seja, um querer bem a algo, em que a população deseja muito por essa eleição, a qual será realizada pelo Congresso Nacional.

Por meio de uma enunciação profética ("já poderá"), incute no leitor a paixão da esperança, porém uma esperança passiva. Paixão que vem caracterizando a construção do discurso "revolucionário" d'O Globo, uma vez que, nesse movimento político, o papel do "povo" é esperar que as Forças Armadas afastem João Goulart e seus aliados, é esperar que o Congresso Nacional eleja o novo Presidente e seu Vice, é esperar que o novo presidente recupere a economia brasileira:

ASSIM, aos dez dias de vitoriosa, já poderá a Revolução oferecer ao País um Govêrno formado segundo os ideais que a inspiraram, em condições, portanto, de empreender, imediatamente, uma obra de recuperação econômica, restauração financeira e saneamento moral (O GLOBO, 1964c).

O editorial, também, instala em seu enunciado o sentimento de comunhão entre os "revolucionários", sentimento que, no nível da enunciação, contagia o leitor do jornal, porque o próprio jornal se assume como parte integrante dessa comunhão, ao afirmar que "[...] nós mesmos, antes da decisão dos Governadores, já apontávamos, em editorial, como o paradigma do militar à altura de ocupar a Suprema Magistratura". Essa comunhão associa-se à indicação pelos governadores estaduais de um único nome - o de Castelo Branco - para disputar a Presidência da República: 
[...] resolveram os Governadores, que foram os líderes civis do movimento revolucionário, indicar ao Congresso, para Presidente, o nome de um de seus principais chefes militares (O GLOBO, 1964c).

NOTE-SE QUE êsses Governadores representam áreas políticas diversas, sendo vários dêles candidatos à Presidência da República nas futuras eleições gerais. Puseram-se, no entanto, de acôrdo em relação àquele que indicariam ao Congresso. Parece que a escolha não foi difícil, [não somente] pelo impulso patriótico que vem animando os Chefes dos Executivos estaduais, mas em face das excelsas qualidades do indicado, o General Humberto Castelo Branco, que nós mesmos, antes da decisão dos Governadores, já apontávamos, em editorial, como o paradigma do militar à altura de ocupar a Suprema Magistratura (O GLOBO, 1964c).

Além dos efeitos passionais da esperança e da comunhão, esse editorial d' $O$ Globo projeta a paixão da confiança, ao abordar a questão de uma possível divisão de forças dentro do comando "revolucionário" em razão do lançamento dos nomes do Marechal Eurico Gaspar Dutra e do General Amauri Kruel para disputar a Presidência com Castelo Branco:

JÁ AGORA, porém, encontram-se igualmente lançados dois outros ilustres militares, que mereceram as preferências de alguns círculos parlamentares, o Marechal Eurico Gaspar Dutra e o General Amauri Kruel. [...] (O GLOBO, 1964c).

Essa confiança é construída no enunciado por meio da modalização em discurso segundo (cf Maingueneau, 2002 [1998], p. 139), que introduz, na superfície discursiva d'O Globo, o discurso do outro, do adversário, do inimigo. Vejamos:

PARA ALGUNS, a apresentação dos nomes dêstes dois corretos militares e cidadãos teria o significado de uma divisão das Fôrças Armadas triunfantes, planejada por grupos políticos interessados em cindir o comando revolucionário, para enfraquecer o movimento de liquidação do comunismo. [...]. Mas não entendemos que o lançamento das candidaturas Dutra e Kruel implique em tal divisão (O GLOBO, 1964c).

A expressão "Para alguns" introduz o discurso citado "a apresentação dos nomes dêstes dois corretos militares e cidadãos teria o significado de uma divisão das Fôrças Armadas triunfantes [...]" e desqualifica o discurso inimigo, uma vez que "alguns" é um pronome indefinido que sugere um número reduzido de integrantes de um dado grupo.

No enunciado "Mas não entendemos que o lançamento das candidaturas Dutra e Kruel implique em tal divisão", novamente discurso inimigo irrompe no fio discursivo por meio da negação polêmica e, ao mesmo tempo, é rechaçado pelo conector argumentativo "mas", que, segundo Maingueneau (1997 [1987], p. 166), 
trata-se do "mas" de refutação, "que recusa a legitimidade daquilo que um detinatário disse ou pensou, ou poderia ter dito ou pensado".

Assim, a estratégia de desqualificação e de refutação do discurso do outro (o inimigo) constrói o efeito passional da confiança. O jornal desperta no leitor a confiança naquilo que é afirmado sobre a eleição presidencial e a reforça oferecendo o seguinte argumento:

DIVISÃO HAVERIA se fôssem buscar um oficial-general que não estivesse integrado no espírito da Revolução, representando, portanto, o surgimento de seu nome um desafio à nova ordem de coisas. Não é o caso. Tanto o Marechal Dutra quanto o General Kruel são homens da Revolução [...] (O GLOBO, 1964c).

Apostando na vitória de Castelo Branco, o editorial d'O Globo desperta no leitor o sentimento de orgulho perante a figura do General Castelo Branco, pois projeta nele a imagem de "grande brasileiro responsável pelo movimento 'revolucionário"':

[...] continuamos a achar que o Congresso deve eleger amanhã aquêle grande brasileiro, que pelas invulgares qualidades, excepcional cultura e papel desempenhado na preparação do movimento revolucionário se impôs como o candidato natural dos chefes civis da jornada democrática $(O$ GLOBO, 1964c).

Por fim, $O$ Globo experimenta ao lado de seu leitor a esperança. Nesse discurso, o sujeito apaixonado espera, com fé, que a direção do General Castelo Branco cumpra a promessa de restituir ao Brasil o "seu lugar no mundo democrático", outrora afastado pelos interesses do comunismo. 


\subsubsection{Os pathé e os ethé das primeiras páginas}

A análise dos gêneros da primeira página do Correio da Manhã de 10 de abril de 1964 mostrou que a manchete e a foto-manchete voltam-se para o acontecimento em torno da instauração de um novo regime político no Brasil por meio da promulgação do Ato Institucional, mantendo um tom enunciativo disfórico, o que revela o afastamento desse discurso jornalístico em relação ao discurso "revolucionário". Vimos também que a nota comentário relatado publica, na íntegra, o Ato Institucional, deixando de lançar explicitamente qualquer avaliação apreciativa no contorno do discurso citado, o que revela não só o efeito de objetividade pretendido pelo discurso como também, reiteradamente, o distanciamento em relação ao posicionamento do discurso "revolucionário".

Quanto às notícias, a análise revelou que o Correio da Manhã produz, em seus enunciados, o efeito de objetividade e de distanciamento não apenas como forma de submeter-se às coerções do gênero "notícia", mas, principalmente, por que o seu discurso - embora favorável à queda de João Goulart - começa a se distanciar do discurso do novo regime político.

No que toca às paixões, após as edições de 2 e 3 de abril, podemos dizer que a primeira página da edição de 10 de abril do Correio da Manhã começa a revelar não só a inquietação e a desconfiança perante o movimento "revolucionário", mas começa a manifestar o efeito passional da decepção. A enunciação da primeira página projeta o seguinte cenário passional:

- A disposição do sujeito apaixonado: o jornal e seu leitor experimentam a quebra de confiança (o Ato Institucional que contraria os direitos democráticos) e o temor (inúmeras prisões de políticos e restrição à atividade jornalística);

- O sujeito desencadeador da paixão: os generais do movimento "revolucionário";

- Os motivos que suscitam a paixão: as restrições impostas pelo Al.

Quanto à edição de 10 de abril d'O Globo, a análise dos gêneros da primeira página mostrou que a manchete e a foto-manchete destacam de maneira eufórica os primeiros efeitos do $\mathrm{Al}$, revelando ao seu leitor o sentimento de satisfação perante as ações do novo regime. 
Mostramos também que as fotos-legendas, embora construam acontecimentos alheios à cobertura do movimento político, produzem um efeito de "real", em que o "mundo capitalista" é valorizado positivamente, o que fortalece o argumento do discurso "revolucionário" contra a "ameaça comunista". Desse modo, o discurso do jornal desperta no seu leitor a paixão da emulação, ou seja, persuade seu leitor a desejar para o seu país a mesma sorte que têm os Estados Unidos da América.

Quanto ao editorial, o leitor é despertado a sentir ansiedade devido à eleição do novo presidente; a sentir esperança na recuperação da economia no novo governo; a sentir comunhão pela indicação do nome de Castelo Branco para a Presidência; a sentir orgulho da figura de Castelo Branco.

Assim, a primeira página da edição de 10 de abril d'O Globo revela a satisfação, a emulação, a esperança, a ansiedade, a comunhão, a confiança e o orgulho, projetando o seguinte cenário passional:

- A disposição do sujeito apaixonado: o jornal e seu leitor experimentam a satisfação (pelos efeitos do Al), a emulação (pelos EUA) e a comunhão, a confiança e a esperança (no novo presidente);

- O sujeito desencadeador da paixão: o Al, os EUA e o novo presidente;

- Os motivos que suscitam a paixão: os primeiros efeitos do Al começam a redemocratizar o Brasil; os grandes feitos dos EUA, símbolo do capitalismo; a eleição do novo presidente.

Confrontando esses dois cenários passionais, vemos que as primeiras páginas do Correio da Manhã e d'O Globo de 10 de abril de 1964 projetam cenografias bem distintas.

O cenário passional projetado pelo Correio da Manhã leva seu leitor a experimentar o sentimento da desconfiança no movimento revolucionário devido à natureza antidemocrática do Ato Institucional e o do temor devido às prisões de deputados e senadores e à iminente restrição à atividade jornalística. Constrói-se, dessa maneira, a cenografia da repressão às liberdades democráticas, na qual se oferece ao leitor o ethos do paladino da democracia e o anti-ethos do tirano (daqueles que agem contra a democracia) e o do omisso (daqueles que assistem passivamente a ação antidemocrática).

O leitor d'O Globo é exposto a uma enunciação euforizante do movimento revolucionário e sua filiação ao modelo capitalista ditado pelos EUA, experimentando 
a satisfação pelos efeitos do Al, a confiança nas Forças Armadas, o orgulho pelo general Castelo Branco, a esperança no novo presidente e a emulação pelo modo de vida dos EUA. Constrói-se o ethos lisonjeiro, que valoriza a classe dominante que toma o poder e oferece possibilidades de ganhos no sistema de abertura aos interesses multinacionais. 


\section{CONSIDERAÇÕES FINAIS}

Neste momento, é preciso retomar e destacar alguns pontos importantes de nosso trabalho. Em primeiro lugar, devemos salientar nossa preocupação em tratar, explicitamente, dos procedimentos teórico-metodológicos adotados em nossa pesquisa, pois nos parece que tão importante quanto apresentar definições teóricas seja discutir os próprios métodos de análise em torno desse objeto de pesquisa que não é somente o discurso, mas o interdiscurso.

Em linhas gerais, tentamos esboçar os pressupostos teóricos da abordagem discursivo-argumentativa, situando-a na interface entre a Análise do Discurso e a Argumentação. Em síntese, tentamos mostrar que as principais consequências acarretadas pela abordagem teórico-metodológica de nossa pesquisa incidiram sobre a constituição do corpus e as categorias de análise, pois a escolha das primeiras páginas dos jornais Correio da Manhã e O Globo ocorreu, principalmente, em virtude de noções como interdiscurso, relação polêmica, espaço discursivo, gênero e hipergênero discursivo etc. (cf. Maingueneau), ao passo que a priorização do ethos e do pathos deve-se ao fato de que essas duas noções suscitam, necessariamente, aspectos discursivos e argumentativos. Se o enfoque teórico fosse outro, poderíamos pensar não em ethos, mas, por exemplo, em processos de subjetivação, identidades discursivas etc. Entretanto, como nossa pesquisa quer refletir, justamente, sobre os aspectos discursivos e argumentativos das instâncias subjetivas de enunciação, elegemos as noções de ethos e de pathos como categorias de análise centrais para nossa pesquisa.

No que diz respeito ao percurso analítico empreendido na pesquisa, podemos dizer que o mesmo pôde nos oferecer condições de mostrar como a composição do hipergênero "primeira página" do jornal mobiliza elementos enunciativos que servem a estratégias discursivo-argumentativas de captação do leitor, as quais passam, principalmente, pela construção da identidade discursiva do jornal e da identificação entre jornal e leitor. Trata-se de uma das preocupações da abordagem teóricometodológica de nossa pesquisa, que compreende a argumentação como fato de discurso, aproximando, assim, os pressupostos da Análise do Discurso e da Teoria da Argumentação.

Quando nos propusemos a responder como a inter-relação dos gêneros jornalísticos no hipergênero "primeira página" contribui para a construção do efeito 
de real, estávamos pensando em ultrapassar uma visada relativamente óbvia acerca dos estudos discursivos sobre a relação entre o político e o jornalístico, pois procuramos mostrar como o layout da primeira página do jornal pode apresentar-se como um discurso gráfico-visual que contribui para a construção dos sentidos manifestados por meio da materialidade verbal.

Outro aspecto suscitado durante a análise diz respeito à projeção das cenas enunciativas no hipergênero "primeira página do jornal". Ao tratar dos regimes de leitura, da captação do imaginário do leitor e de sua identificação com o jornal, tocamos, de fato, no problema da construção do leitor. Em outras palavras, dissemos que o leitor é um feixe de estratégias enunciativas e uma construção do próprio discurso jornalístico. Abordamos, pois, o leitor enquanto princípio discursivo, e não o leitor empírico.

Assim, a análise do discurso gráfico-visual dos jornais pôde revelar como as cenas enunciativas projetadas pela primeira página captam o imaginário do leitor, conferindo papéis sociais aos parceiros da comunicação, jornal e leitor, atribuindoIhes também modos de ser (ethos) e de sentir (pathos), orientando-Ihes a posicionamentos discursivos perante a situação política do país num determinado momento histórico.

Mostrou que, se a primeira página do Correio da Manhã requer um leitor que deve acompanhar o raciocínio argumentativo do jornal e das vozes relatadas no jornal, atribuindo-Ihe a imagem de um leitor participativo, e, se a primeira página d'O Globo destina-se a um leitor mais afeito a acompanhar os fatos políticos por meio de fotografias, conferindo-lhe a imagem de um leitor espectador, emergem, nesse contexto sócio-histórico de abril de 1964, duas identidades discursivas distintas e com posicionamentos discursivos bem definidos em relação ao episódio político que marcou o Brasil em 1964.

De modo geral, pudemos entender até o momento que a deposição do presidente João Goulart foi um acontecimento que organizou duas formações discursivas que já vinham se alinhando de acordo com a política internacional ditada pela "Guerra fria". Vimos que, no primeiro momento após a queda de João Goulart, a chamada grande imprensa não apresentava - à primeira vista - posicionamentos ideológicos discordantes. No entanto, pudemos mostrar que tal afirmação não resiste a um exame pouco mais cuidadoso da matéria jornalística. 
Mostramos, também, que os pathé e os ethé que emergiram dos discursos do Correio da Manhã e d'O Globo localizam-se em dois polos diametralmento opostos na polêmica entre democráticos e antidemocráticos, ou entre "revolucionários" e "antigolpistas". Enquanto um reproduz o discurso que defende a democracia, o outro constrói um discurso confiante nas Forças Armadas como o herói que livrará o Brasil do comunismo e restituirá a democracia.

Assim, a pesquisa tentou mostrar como o pathos participa da construção do ethos, revelando que as edições de 2, 3 e 10 de abril de 1964 do Correio da Manhã constroem um percurso passional que vai da satisfação preocupada à quebra da confiança no movimento "revolucionário" e que corrobora a construção do ethos do jornal imparcial e distanciado dos valores do discurso revolucionário, inscrevendo seu discurso no que chamamos de formação discursiva "antigolpista". A pesquisa mostrou também que $O$ Globo projeta paixões que euforizam o movimento revolucionário, construindo o ethos do jornal lisonjeiro, oferecendo ao leitor a imagem de um povo grato às Forças Armadas pela restituição da democracia. Conclui, portanto, o vínculo entre o pathos, o ethos, o posicionamento e a identidade discursiva de cada jornal no interior da polêmica entre as FDs "revolucionária" e "antigolpista".

Além de recuperar os aspectos que julgamos mais importante na pesquisa, este é o momento também de considerar as perspectivas que podemos vislumbrar a partir deste trabalho.

Como pudemos depreender do discurso jornalístico do Correio da Manhã e d'O Globo um rol de paixões recorrentes, tais como a esperança, a confiança, a desconfiança, a decepção, a indignação, o sentimento de justiça, seria válido nos questionar se existiriam, especificamente, as paixões do discurso jornalístico. Para responder a essa pergunta, acreditamos que outros trabalhos poderiam investigar as paixões no discurso jornalístico, examinando jornais de outras épocas e de outras localidades ou focalizando outros acontecimentos polêmicos, pois, da mesma forma que estudamos as paixões construídas nos discursos jornalísticos sobre a polêmica instaurada pelo movimento político de 1964, vislumbramos a possibilidade de estudos das paixões sobre outras polêmicas específicas.

Para além do discurso jornalístico, esta pesquisa aponta também para a possibilidade de estudos do pathos em outros tipos discursivos. Nesse sentido, os 
questionamentos incidiriam sobre as paixões no discurso literário, no discurso político, no discurso religioso, no discurso publicitário e assim por diante.

O estudo das paixões desemboca no estudo das construções de imagens dos atores envolvidos nos acontecimentos discursivos. Assim como exploramos a representação que os jornais fizeram dos políticos "revolucionários" e "antigolpistas", bem como a construção de sua própria imagem e a de seu leitor, valeria examinar a imagem que o político constrói de seu eleitor, de seus adversários, de seus correligionários, da imprensa, assim como seria relevante compreender a imagem que um determinado material didático projeta de seus leitores, o professor e o aluno, e a imagem que o próprio livro projeta de si.

Em Novas tendências em Análise do Discurso, Maingueneau (1987 [1987]) afirma que os analistas dificilmente mostram interesse pela análise de campos discursivos. Nossa pesquisa mencionou, de forma transversal, essa questão ao abordar a presença do discurso religioso no discurso político e a presença deste no discurso jornalístico, ao analisar a nota comentário relatado publicada pelo Correio da Manhã na edição de 2 de abril de 1964, em que simula a enunciação da proclamação deixada por João Goulart ao povo brasileiro em razão de sua deposição. Entendemos que, se neste trabalho, a temática dos campos discursivos ficou em segundo plano, essa relação entre o político e o religioso pode ser estudada de maneira vertical numa outra pesquisa.

Outra questão diz respeito à apuração do ethos discursivo, pois, se, em nosso mestrado, mostramos como o ethos pode ser depreendido por meio de categorias de análise, tais como a dêixis enunciativa, a modalização, o discurso citado, entre outras, nesta pesquisa de doutorado, tentamos mostrar como o ethos pode ser analisado por meio do exame do pathos discursivo. A perspectiva que se apresenta é a de que, apesar de tantos trabalhos produzidos nesta década sobre o ethos discursivo, ainda há um campo de pesquisa a ser explorado no que tange ao levantamento de categorias de análise do ethos, bem como à sua aplicação nos mais variados tipos e gêneros do discurso.

Tentamos, ainda, enfatizar o trabalho que Ruth Amossy vem desenvolvendo no sentido de compreender a argumentação como uma dimensão do discurso e de mostrar a função argumentativa de determinadas categorias discursivas. Trata-se de uma perspectiva de estudos que encampa, de fato, a interface entre a Análise do Discurso e a Argumentação e que nos inspira a refletir sobre seus possíveis 
desdobramentos. Amossy (2011 [2008], p. 133), ao afirmar que "é preciso estudar de perto a maneira como a argumentação se inscreve, não somente na materialidade discursiva [...], mas também no interdiscurso", permite-nos aproximar e relacionar noções e conceitos antes entendidos como pertencentes única e exclusivamente à Análise do Discurso ou à Argumentação.

Nesta tese, voltamo-nos para a descrição do pathos discursivo com base na análise do cenário passional, uma categoria formulada nesta pesquisa para recobrir a projeção das paixões como uma cena de enunciação, destacando nessa formulação a noção de cenografia, tal como desenvolvida por Maingueneau, e o seu papel de captar o imaginário do leitor. O que fica latente nesse trabalho é a perspectiva de uma pesquisa em Análise do Discurso e Argumentação que integre ou, ao menos considere com a sua devida profundidade, uma teoria do imaginário.

Poderíamos, portanto, pensar num estudo sobre a relação entre a cenografia e as figuras retóricas, perscrutando o papel das figuras retóricas na construção da cenografia e, consequentemente, nos aprofundarmos na questão do funcionamento discursivo da cenografia na captação do imaginário do leitor, do ouvinte ou do auditório. Quando se fala em captação do imaginário, quer se remeter a algo que vai além da captação da benevolência do auditório, pois não se trata apenas de convencer o auditório por meio do raciocínio, nem tocá-lo por meio das emoções e da imagem de si, mas sim de despertar os desejos mais profundos desse auditório. Pode-se despertar o interesse por essa interface, uma vez que o imaginário é uma dimensão do fazer persuasivo que está presente em inúmeros discursos, tais como o publicitário, o político, o amoroso etc. Grosso modo, poderíamos dizer que a dimensão do imaginário é permeada pela modalidade volitiva, cuja tradução encerrar-se-ia no enunciado "eu quero". A questão que poderíamos colocar é que os discursos não só exploram os quereres, como também os engendram. Talvez fosse interessante aproximar o conceito de imaginário de conceitos como estereótipo, lugar-comum, doxa e formação discursiva.

$\mathrm{E}$, dessa maneira, as questões vão se colocando e vamos percebendo como a interface entre a Análise do Discurso e a Argumentação ainda pode ser explorada.

Com estas palavras finais, ficamos na expectativa de prosseguir com a pesquisa em qualquer um desses desdobramentos aqui vislumbrados. 


\section{REFERÊNCIAS}

ADAM, Jean-Michel. Unités rédactionnelles et genres discursifs: cadre général pour une approche de la presse écrite. Pratiques, Metz, n.94, p. 2-18, jun 1997.

Types de textes ou genres de discours? Comment classer les textes qui disent de et comment faire? Langages, Paris, vol.35, n.141, p. 10-27, 2001.

ADÃO, Sônia Maria. Análise do Discurso e relações interdisciplinares: questões metodológicas de análise. In: MOSCA, Lineide Salvador (Org.). Discurso, argumentação e produção de sentido. São Paulo: Humanitas, 2006. p. 33-46.

ALEXANDRE JÚNIOR, Manuel. Prefácio. In: ARISTÓTELES. Retórica. Tradução de Manuel Alexandre Júnior, Paulo Farmhouse Alberto e Abel do Nascimento Pena. Lisboa: Imprensa Nacional - Casa da Moeda, 1998. p. 7-40 [c.400 a.C].

AMOSSY, Ruth. La nouvelle rhétorique au prisme de la analyse du discours. In: OLIVEIRA, Eduardo Chagas (Org). Chaïm Perelman: direito, retórica e teoria da argumentação. Feira de Santana: Universidade Estadual de Feira de Santana \& Núcleo Interdisciplinar de Estudos e Pesquisa em Filosofia, 2004. p. 239-258.

(Org.). Imagens de si no discurso: a construção do ethos. Tradução de Dilson Ferreira da Cruz, Fabiana Komesu e Sírio Possenti. São Paulo: Contexto, 2005.

. L'argumentation dans le discours. Discours politique, literature d'idées, fiction. $2^{\mathrm{e}}$ ed. Paris: Armand Colin, 2006.

O lugar da argumentação na análise do discurso: abordagens e desafios contemporâneos. Tradução de Adriana Zavaglia. Filologia e linguística portuguesa, SP, n.9, p. 121-146, 2007.

Argumentação e Análise do Discurso: perspectivas teóricas e recortes disciplinares. Tradução de Eduardo Lopes Piris e Moisés Olímpio Ferreira. EID\&A Revista Eletrônica de Estudos Integrados em Discurso e Argumentação, llhéus, n.1, p. 129-144, 2011 [Original: Argumentation et Analyse du discours: perspectives théoriques et découpages disciplinaires. Argumentation et Analyse du Discours [En ligne], n.1, 2008, mis en ligne le 06 septembre 2008. URL: http://aad.revues.org/index200.html].

ANDRADE, Jeferson Ribeiro de. Um jornal assassinado: a última batalha do Correio da Manhã. Rio de Janeiro: José Olympio, 1991.

AQUINO, Maria Aparecida de. Censura, Imprensa, Estado Autoritário (19681978): o exercício cotidiano da dominação e da resistência O Estado de São Paulo e Movimento. Bauru: EDUSC, 1999. 
ARISTÓTELES. Retórica. Tradução de Manuel Alexandre Júnior, Paulo Farmhouse Alberto e Abel do Nascimento Pena. Lisboa: Imprensa Nacional - Casa da Moeda, 1998 [c.400 a.C].

Retórica das paixões. Tradução de do grego Isis Borges B. da Fonseca. São Paulo: Martins Fontes, 2000 [c.400 a.C].

. Ética a Nicômacos. 3. ed. Tradução do grego de Mario da Gama Kury. Brasília: Editora Universidade de Brasília, 2001 [c.400 a.C].

ASSUNÇÃO, Antônio Luiz. Representação e discurso midiático: reflexões em torno da produção de sentido. In: EMEDIATO, Wander; MACHADO, Ida Lúcia; MENEZES, William (Org.). Análise do Discurso: gêneros, comunicação e sociedade. Belo Horizonte: NAD/POSLIN/FALE-UFMG, 2006. p. 13-24.

AUTHIER-REVUZ, Jacqueline. Heterogeneidade(s) enunciativa(s). Tradução de Celene M. Cruz e João Wanderley Geraldi. Cadernos de Estudos Linguísticos, Campinas, n.19, p. 25-42, jul./dez.1990.

. Palavras incertas: as não-coincidências do dizer. Revisão da Tradução de Eni Puccinelli Orlandi. Campinas: Unicamp, 1998.

Heterogeneidade mostrada e heterogeneidade constitutiva: elementos para uma abordagem do outro no discurso. In: . Entre a transparência e a opacidade: um estudo enunciativo do sentido. Revisão da Tradução de Leci Borges Barbisan et al. Porto Alegre: Edipucrs, 2004. p. 11-80.

BAKHTIN, Mikhail (VOLOCHINOV, V.N.). Marxismo e filosofia da linguagem. Tradução de Michel Lahud e Yara Frateschi Vieira. 9. ed. São Paulo: Hucitec; Annablume, 2002.

BAKHTIN, Mikhail. Os gêneros do discurso. In: Estética da criação verbal. Tradução de Paulo Bezerra. São Paulo: Martins Fontes, 2003. p. 261-306.

BANDEIRA, Moniz Luiz Alberto. O golpe militar de 64 como fenômeno de política internacional. In: TOLEDO, Caio Navarro de. 1964: visões críticas do golpe: democracia e reformas no populismo. Campinas: Unicamp, 1997. p. 83-99.

BARONAS, Roberto Leiser (org.). Análise do Discurso: apontamentos para uma história da noção-conceito de formação discursiva. São Carlos: Pedro \& João Editores, 2007.

BARTHES, Roland. Rhétorique de l'image. Communications, Paris, vol.4, n.1, p. 40-51, 1964.

A Retórica Antiga. In: COHEN, Jean et al. Pesquisas de Retórica.

Tradução de Leda Pinto Mafra Iruzun. Petrópolis: Vozes, 1975. p. 147-221. 
A câmara clara: nota sobre a fotografia. Tradução de Júlio Castañon Guimarães. Rio de Janeiro: Nova Fronteira, 1984.

$O$ efeito de real. In:

O rumor da língua. Tradução de Mário Laranjeira. Prefácio de Leyla Perrone-Moisés. São Paulo: Brasiliense, 1988.

BAUMLIN, James S.; BAUMLIN, Tita French (Ed.). Ethos: New Essays in Rhetorical and Critical Theory. Dallas, TX: Southern Methodist University Press, 1994.

BENVENISTE, Émile. O homem na língua. In: Problemas de Linguística

Geral I. Tradução de Maria da Glória Novak e Maria Luisa Neri. São Paulo: Nacional/Edusp, 1976. p. 247-315.

. O aparelho formal da enunciação. In: Problemas de Linguística

Geral II. Tradução de Eduardo Guimarães et al. Campinas: Pontes, 1989. p. 81-90.

BOLTANSKI, Luc. La Souffrance à distance, morale humanitaire, médias et politique. Paris: Métaillé, 1993.

BONINI, Adair. Os gêneros do jornal: o que aponta a literatura da área de comunicação no Brasil? Linguagem em (dis)curso, Tubarão, SC, v. 4, n. 1, p. 205231, jul./dez. 2003.

. Veículo de comunicação e gênero textual: noções conflitantes. D.E.L.T.A. Documentação de Estudos em Linguística Teórica e Aplicada, São Paulo, vol.19, n.1, p. 65-89, 2003a.

O conceito de gênero textual/discursivo: teorias versus fenômeno. In: CRISTÓVÃO, Vera Lúcia Lopes; NASCIMENTO, Elvira Lopes (Org.). Gêneros textuais: teoria e prática. Londrina: Moriá, 2004. p. 3-17.

. Os gêneros do jornal. Questões de pesquisa e ensino. In: KARWOSKI, Acir Mário; GAYDECZKA, Beatriz; BRITO, Karim Siebeneicher. Gêneros textuais: reflexões e ensino. 2.ed. Rio de Janeiro: Lucerna, 2006. p. 57-71.

As relações constitutivas entre 0 jornal e seus gêneros: relato das pesquisas do "Projeto Gêneros do Jornal". In: BRAGA, Sandro et al (Org.). Ciências da linguagem: avaliando o percurso, abrindo caminhos. Blumenau: Nova Letra, 2008. p. 21-45.

. Hipergênero, mídia e suporte: gêneros textuais e suas relações. (Mimeo).

BONNAFOUS, Simone. L'Analyse du Discours Politique. In: MARI, Hugo et al (Org.). Fundamentos e dimensões da Análise do Discurso. Belo Horizonte: Carol Borges, 1999. 
BRAIT, Beth. Ironia em perspectiva polifônica. Campinas: Ed. da Unicamp, 1996.

Análise do discurso e argumentação: o exemplo da ironia. In: MARI, Hugo et al (Org.). Fundamentos e dimensões da Análise do Discurso. Belo Horizonte: Carol Borges, 1999. p. 335-347.

BRANDÃO, Helena Hathsue Nagamine. Subjetividade, argumentação, polifonia. A propaganda da Petrobrás. São Paulo: Ed. da Unesp; Imprensa Oficial do Estado, 1998.

Texto, gêneros do discurso e ensino. In: . (Coord.). Gêneros do discurso na escola: mito, conto, cordel, discurso político, divulgação cientifica. São Paulo: Cortez, 2000. p. 17-45. (Coleção aprender e ensinar com textos, v.5).

Unicamp, 2004.

Introdução à Análise do Discurso. 2.ed.rev. Campinas: Editora da

BUCCI, Eugênio. Introdução: O jornalismo ordenador. In: GOMES, Mayra Rodrigues. O poder no jornalismo: discorrer, disciplinar, controlar. São Paulo: Hacker Editores; Edusp, 2003. p. 9-13.

CARMAGNANI, Anna Maria Grammatico. A argumentação e o discurso jornalístico: a questão da heterogeneidade em jornais ingleses e brasileiros. São Paulo, 1996. 348f. Tese (Doutorado em Linguística Aplicada) - Pontifícia Universidade Católica de São Paulo.

CARVALHO, Flaviane Faria. Os significados composicionais e a formação de subjetividades na primeira página de jornais mineiros: um estudo de caso à luz da gramática do design visual. 2007. 123f. Dissertação (mestrado em Estudos Linguísticos) - Faculdade de Letras, Universidade Federal de Minas Gerais, Belo Horizonte, 2007.

; MAGALHÃES, Célia. Mídia impressa e multimodalidade: os significados composicionais na primeira página de jornais mineiros. Revista Anpoll, (on line), vol.2, n.27, p. 43-71, 2009.

CERVONI, Jean. A enunciação. Tradução de L. Garcia dos Santos. São Paulo: Ática, 1989.

CHACON, Vamireh. História dos partidos brasileiros: discurso e práxis dos seus programas. 3. ed. ampliada e atualizada. Brasília: Ed. Universidade de Brasília, 1998.

CHARAUDEAU, Patrick. Visadas discursivas, gêneros situacionais e construção textual. In: MACHADO, Ida Lúcia; MELLO, Renato de (Org.). Gêneros: reflexões em Análise do Discurso. Belo Horizonte: NAD/POSLIN/FALE-UFMG, 2004. p. 13-41. 
Discurso político. Tradução de Fabiana Komesu e Dilson Ferreira da Cruz. São Paulo: Contexto, 2006 [Original: Le discours politique. Les masques du pouvoir. Paris: Vuibert, 2005].

Discurso das mídias. Tradução de Ângela S. M. Corrêa. São Paulo: Contexto, 2007a [Original: Les médias et l'information. Bruxelles: De Boeck \& Larcier, Institut National de L'audiovisuel, 2005].

Pathos e discurso político. Tradução de Emília Mendes. In: MACHADO, Ida Lúcia; MENEZES, William; MENDES, Emília. As emoções no discurso. Rio de Janeiro: Lucerna, 2007b. p. 240-251.

. Linguagem e discurso: modos de organização. Coordenação da equipe de tradução Ângela M. S. Corrêa e Ida Lúcia Machado. São Paulo: Contexto, 2008.

A patemização na televisão como estratégia de autenticidade. Tradução de Renato de Mello. In: MENDES, Emília; MACHADO, Ida Lúcia (Org.). As emoções no discurso. Vol.II. Campinas: Mercado de Letras, 2010. p. 23-56. [Original : Une problématisation discursive de l'émotion: à propos des effets de pathémisation à la television. In: PLANTIN, Christian; DOURY, Marianne; TRAVERSO, Véronique (Éds). Les émotions dans les interactions. Lyon: Presses Universitaires Lyon, 2000].

; MAINGUENEAU, Dominique. Dicionário de Análise do Discurso. Coordenação da Tradução de Fabiana Komesu. São Paulo, Contexto, 2004.

CHAUVEL, Lucrecia Escudero. Disparus, passions et identités discursives dans la presse argentine (1976-1983). Hermès, Paris, n.28, p. 157-174, 2000.

CORACINI, Maria José Rodrigues Faria. Análise do Discurso: em busca de uma metodologia. D.E.L.T.A. Documentação de Estudos em Linguística Teórica e Aplicada, v. 07 (1), p. 333-355, 1991.

CORREIO DA MANHÃ. Rio de Janeiro, 2 abr. 1964a, p. 1.

. Rio de Janeiro, 3 abr. 1964b, p. 1.

. Rio de Janeiro, 10 abr. 1964c, p. 1.

COURTINE, Jean-Jacques. Analyse du discours politique (le discours communiste adressé aux chrétiens). Langages, Paris: n.62, juin 1981.

DECLERCQ, Gilles. L'art d'argumenter: structures rhétoriques et littéraires. Paris: Editions Universitaires, 1992. 
DIAS, Ana Rosa Ferreira. O discurso da violência: as marcas da oralidade no jornalismo popular. 3.ed. São Paulo: Cortez Editora, 2008.

DISCINI, Norma. O estilo nos textos. São Paulo: Contexto, 2003.

DITTRICH, Ivo José. Lingüística e Jornalismo: dos sentidos à argumentação. Cascavel: Edunioeste, 2003.

- Retórica dos títulos em reportagens impressas. Comunicação \& Educação, v. 11, n. 1, 2009.

DREIFUSS, René Armand. 1964: A conquista do Estado: ação política, poder e golpe de classe. 2. ed. Tradução de Else Ribeiro Pires Vieira (superv.). Petrópolis, Vozes, 1981.

DUCROT, Oswald. A propos de la seconde Provinciale. Langue française, Paris, n.12, 1971.

. Esboço de uma teoria polifônica da enunciação. In: dito. Tradução de Eduardo Guimarães. Campinas, SP: Pontes, 1987. O dizer e $o$

EGGS, Ekkehard. Logos, ethos, pathos - l'actualité de la rhétorique des passions chez Aristote. In: PLANTIN, Christian; DOURY, Marianne; TRAVERSO, Véronique (Éds). Les émotions dans les interactions. Lyon: Presses Universitaires Lyon, 2000. p. 15-31.

Ethos aristotélico, convicção e pragmática moderna. In: AMOSSY, Ruth (Org.). Imagens de si no discurso: a construção do ethos. Tradução de Dilson Ferreira da Cruz, Fabiana Komesu e Sírio Possenti. São Paulo: Contexto, 2005. p. 29-56.

FERREIRA JÚNIOR, José. Capas de jornal: a primeira imagem e o espaço gráficovisual. São Paulo: Editora SENAC, 2003.

FERREIRA, Moisés Olímpio. Estudo do discurso religioso sob a perspectiva da Nova Retórica. In: GARCIA, B.R.V. et al (Org.). Análises do Discurso: o diálogo entre as várias tendências na USP. São Paulo: Paulistana Editora, 2009. Disponível em: http://www.epedusp. org

FIGUEIREDO, Lisete Fernandes. A nota jornalística no Jornal do Brasil: um estudo do gênero textual e de sua função no jornal. Tubarão, 2003. 134f. Dissertação (Mestrado em Ciências da Linguagem) - Universidade do Sul de Santa Catarina.

FIORIN, José Luiz. O regime de 1964: discurso e ideologia. São Paulo: Atual, 1988. 
Algumas considerações sobre o medo e a vergonha. Cruzeiro Semiótico, n. 16, Porto, 1992.

As astúcias da enunciação. São Paulo: Ática, 1996.

O éthos do enunciador. In: CORTINA, Arnaldo; MARCHEZAN, Renata Coelho (Org.). Razões e sensibilidades. Araraquara: Cultura Acadêmica Editora, 2004, v.1, p. 117-138.

- Prefácio. In: BEIVIDAS, Waldir. Semióticas Sincréticas (o cinema). Posições. Edição on line. Departamento Nacional do Livro, 2006, p. 3-8.

FOUCAULT, Michel. A arqueologia do saber. Tradução de Luiz Felipe Baeta Neves. Petrópolis: Vozes, 1972 [Original: L’Archéologie du savoir. Paris: Éditions Gallimard, 1969].

A ordem do discurso. Tradução de Laura Fraga de Almeida Sampaio. 9.ed. São Paulo: Loyola, 2003 [Original: L'ordre du discours. Leçon inaugurale au Collège de France prononcée le 2 décembre 1970. Paris: Éditions Gallimard, 1971].

GREGOLIN, Maria do Rosário Valencise (Org.). Recitações de mitos: a história na lente da mídia. In: Filigranas do discurso: as vozes da história. Araraquara: FCL/ Laboratório Editorial/ UNESP; São Paulo: Cultura Acadêmica, 2000. p. 19-34.

Foucault e Pêcheux na Análise do Discurso: Diálogos \& Duelos. São Carlos, SP: Claraluz, 2006.

GREIMAS. Algirdas Julien. De la colère. Étude de sémantique lexicale. Actes Sémiotiques - Documents, n. 27, v. 3, Paris, 1981.

GRIGOLETTO, Marisa. A resistência das palavras. Discurso e colonização britânica na Índia. Campinas: Editora da Unicamp, 2002.

GRILLO, Sheila Vieira de Camargo. Função dos gêneros e metodologia na constituição do corpus em Análise do Discurso. Revista do 50ำ Seminário do Grupo de Estudos Linguísticos do Estado de São Paulo, São Paulo, 2003.

A produção do real em gêneros do jornal impresso. São Paulo: Associação Editorial Humanitas, 2004.

Enunciados verbo-visuais na divulgação científica. Revista Anpoll, (on line), vol.2, n.27, p. 215-243, 2009.

HADDAD, Galit. Ethos prévio e ethos discursivo: o exemplo de Romain Rolland. In: AMOSSY, Ruth (Org.). Imagens de si no discurso: a construção do ethos. 
Tradução de Dilson Ferreira da Cruz, Fabiana Komesu e Sírio Possenti. São Paulo: Contexto, 2005. p. 145-165.

HERNANDES, Nilton. A revista Veja e o discurso do emprego na globalização: uma análise semiótica. São Paulo, 2001. 160f. Dissertação (Mestrado em Semiótica e Linguística Geral) - Faculdade de Filosofia, Letras e Ciências Humanas, Universidade de São Paulo.

KERBRAT-ORECCHIONI, Catherine. L'énonciation. De la subjectivité dans le langage. Paris: Armand Colin, 1980.

KINDERMANN, Conceição Aparecida. A reportagem jornalística no jornal do Brasil: desvendando as variantes do gênero. Tubarão, SC, 2003. 141f. Dissertação (Mestrado em Ciências da Linguagem) - Universidade do Sul de Santa Catarina.

KRESS, Gunther. Front Pages: (The Critical) Analysis of Newspaper Layout. In: BELL, Allan; GARRETT, Peter (Ed.). Approaches to Media Discourse. Oxford: Blackwell, 1998.

; Van LEEUWEN, Theo. Reading Images: the Grammar of Visual Design. London; New York: Routledge, 1996.

KUCINSKI, Bernardo. Jornalistas e revolucionários: nos tempos da imprensa alternativa. São Paulo: Scritta, 1991.

LANDOWSKI, Eric. Presenças do Outro: ensaios de sociossemiótica. Tradução de Mary Amazonas Leite de Barros. São Paulo: Perspectiva, 2002.

LEIBRUDER, Ana Paula. O posicionamento da UDN sobre o projeto de reforma agrária do governo João Goulart (1963-1964): estratégias de silenciamento da polifonia enunciativa. São Paulo, 2007. 184f. Dissertação (Mestrado em Filologia e Língua Portuguesa) - Faculdade de Filosofia, Letras e Ciências Humanas, Universidade de São Paulo.

LOCHARD, Guy. Genres rédactionnels et appréhension de l'événement médiatique. Vers un déclin des «modes configurants»? Réseaux, Paris, vol. 14, n. 76, p. 83-102, 1996.

LUSTOSA, Isabel. O nascimento da imprensa brasileira. Rio de Janeiro: Jorge Zahar, 2003.

LYSARDO-DIAS, Dylia. O discurso do estereótipo na mídia. In: EMEDIATO, Wander; MACHADO, Ida Lúcia; MENEZES, William (Org.). Análise do Discurso: gêneros, comunicação e sociedade. Belo Horizonte: NAD/POSLIN/FALE-UFMG, 2006. p. 2536. 
MACHADO, Ida Lúcia. Emoções, ironia, AD: breve estudo de um discurso literário. In: ; MENEZES, William; MENDES, Emília. (Org.). As emoções no discurso. Rio de Janeiro: Lucerna, 2007. p. 169-181.

; MENEZES, William; MENDES, Emília. (Org.). As emoções no discurso. Rio de Janeiro: Lucerna, 2007.

MAINGUENEAU, Dominique. L'analyse du discours. Introductions aux lectures de l'archive. Paris, Hachete, 1991.

. Novas Tendências em Análise do Discurso. Tradução de Freda Indursky. 3. ed. Campinas: Pontes, 1997. [Original: Nouvelles tendances en Analyse du Discours. Paris: Hachette, 1987].

Termos-chave da Análise do Discurso. Tradução de Márcio Venício Barbosa e Maria Emília Amarante Torres Lima. Belo Horizonte: Ed.UFMG, 2000.

Lecture, incorporation et monde éthique. Études de Linguistique Appliquée (Éla), Paris, n.119, p. 265-275, juil./sept. 2000a.

. O contexto da obra literária: enunciação, escritor, sociedade. Tradução de Marina Appenzeller. São Paulo: Martins Fontes, 2001. [Original: Le contexte de l'oeuvre littéraire - énonciation, écrivain, société. Paris: Dunod, 1993].

Análise de textos de comunicação. Tradução de Cecília P. Souza-e-Silva e Décio Rocha. 2.ed. São Paulo: Cortez, 2002. [Original: Analyser les textes de communication. Paris: Dunod, 1998].

Diversidade dos gêneros discursivos. In: MACHADO, Ida Lúcia; MELLO, Renato de (Org.). Gêneros: reflexões em Análise do Discurso. Belo Horizonte: NAD/POSLIN/FALE-UFMG, 2004. p. 43-57.

. Ethos, cenografia, incorporação. In: AMOSSY, Ruth (Org.). Imagens de si no discurso: a construção do ethos. Tradução de Dilson Ferreira da Cruz, Fabiana Komesu e Sírio Possenti. São Paulo: Contexto, 2005. p. 69-92.

Problemas de ethos. In: Cenas da enunciação. Organização de Sírio Possenti e Maria Cecília Pérez de Souza-e-Silva. Curitiba: Criar, 2006. [Original: Problèmes d'ethos. Pratiques, Metz, n.113-114, p. 55-67, juin. 2002].

Gênese dos discursos. Tradução de Sírio Possenti. Curitiba: Criar, 2007. [Original: Genèses du discours. Liège: P. Mardaga, 1984].

A propósito do ethos. Tradução de Luciana Salgado. In: MOTTA, Ana Raquel; SALGADO, Luciana (Org.). Ethos discursivo. São Paulo: Contexto, 2008. p. 11-29. 
Argumentação e Análise do Discurso: reflexões a partir da segunda Provincial. Tradução de Eduardo Lopes Piris e Moisés Olímpio Ferreira. In: BARONAS, Roberto Leiser; MIOTELLO, Valdemir (Org.). Análise de Discurso: teorizações e métodos. São Carlos: Pedro \& João Editores, 2011. p. 69-86. [Original : Argumentation et analyse du discours: réflexions à partir de la seconde Provinciale. L'Année sociologique, Paris, n.44, p. 263-279, 1994].

MARCONDES FILHO, Ciro. Comunicação e jornalismo. A saga dos cães perdidos. 2.ed. São Paulo, Hacker Editores, 2002.

MARIANI, Bethânia Sampaio Corrêa. Sobre um percurso de análise do discurso jornalístico - a Revolução de 30. In: INDURSKY, Freda; FERREIRA, Maria Cristina Leandro. Os múltiplos territórios da Análise do Discurso. Porto Alegre: Sagra Luzzatto, 1999. p. 102-121.

MATOS, Heloiza Helena Gomes de. Modos de olhar o discurso autoritário no Brasil (1969-1974): o noticiário de primeira página na imprensa e a propaganda governamental na televisão. São Paulo, 1989. 213f. Tese (Doutorado em Ciências da Comunicação) - Escola de Comunicação e Artes, Universidade de São Paulo.

MAURO, Maria Adélia Ferreira. Argumentação e discurso. In: MOSCA, Lineide Salvador (Org.). Retóricas de ontem e de hoje. São Paulo: Humanitas, 1997. p. 183-200.

O percurso interpretativo de um discurso argumentativo. Língua e literatura. São Paulo, n.23, p. 79-96, 1997a.

MAZIĖRE, Francine. A análise do discurso: história e práticas. Tradução de Marcos Marcionilo. São Paulo: Parábola Editorial, 2007 [Original: L’analyse du discours. Paris: Presses Universitaires de France, 2005].

MENDES, Emília; MACHADO, Ida Lúcia (Org.). As emoções no discurso. Vol.II. Campinas: Mercado de Letras, 2010.

MENEZES, William Augusto. Discurso político e gêneros discursivos. In: MACHADO, Ida Lúcia; MELLO, Renato de (Org.). Gêneros: reflexões em Análise do Discurso. Belo Horizonte: NAD/POSLIN/FALE-UFMG, 2004. p. 243-261.

Ethos, ética e lugares de degenerescência do discurso político. In: EMEDIATO, Wander; MACHADO, Ida Lúcia; MENEZES, William (Org.). Análise do Discurso: gêneros, comunicação e sociedade. Belo Horizonte: NAD/POSLIN/FALEUFMG, 2006. p. 311-331.

MEURER, José Luiz; BONINI, Adair; MOTTA-ROTH, Désirée (Org.). Gêneros Teorias, Métodos, Debates. São Paulo: Parábola Editorial, 2005. 
MEYER, Michel. Questions de rhétorique: langage, raison et séduction. Paris, Librairie Générale Française, 1993.

Aristóteles ou a retórica das paixões. In:

Retórica das paixões.

Tradução do grego de Isis Borges B. da Fonseca. São Paulo: Martins Fontes, 2000. p. XVII-LI (prefácio) [Original: Rhétorique des passions. Postface de Michel Meyer. Paris: Éditions Rivages, 1989].

Perelman. Le renouveau de la Rhétorique. Paris: PUF, 2004.

A retórica. Apresentação e Revisão Técnica de Lineide Salvador Mosca. São Paulo: Ática, 2007.

MILLER, Carolyn R. Genre as social action. In: FREEDMAN, Aviva; MEDWAY, Peter (Eds.). Genre and the new rhetoric. London: Taylor \& Francis, 1994 [1984]. p. 2342.

MORETZSOHN, Sylvia. "Profissionalismo" e "objetividade": o jornalismo na contramão da política. 2001. BOCC Biblioteca on-line de ciências da comunicação. Covilhã, Portugal, LabCom - Laboratório de Comunicação On-Line: Universidade da Beira Interior, p. 1-14. Anual. ISSN 1646-3137. Disponível em: $<$ http://www.bocc.ubi.pt/pag/moretzsohn-sylvia-profissionalismo-jornalismo.pdf>. Acesso em: 5 jan. 2008.

MOSCA, Lineide Salvador. Subjetividade no editorial: uma análise retóricoargumentativa da adjetivação. São Paulo, 1990. 406f. Tese (Doutorado em Filologia e Língua Portuguesa) - Faculdade de Filosofia, Letras e Ciências Humanas, Universidade de São Paulo.

. Velhas e novas retóricas: convergências e desdobramentos. In:

(Org.). Retóricas de ontem e de hoje. São Paulo: Humanitas, 1997. p. 17-54.

Subjetividade e formação de opinião na mídia impressa. In: GHILARDI, Maria Inês; BARZOTTO, Valdir Heitor (Org.). Nas telas da mídia. Campinas: ALB \& Alínea, 2002. p. 9-22.

A teoria perelmaniana e a questão da afetividade. In: OLIVEIRA, Eduardo Chagas (Org). Chaïm Perelman: direito, retórica e teoria da argumentação. Feira de Santana: Universidade Estadual de Feira de Santana \& Núcleo Interdisciplinar de Estudos e Pesquisa em Filosofia, 2004. p. 129-140.

. Discurso, argumentação e persuasão: uma revisão crítica. São Paulo, 2007a. 254f. Tese (Livre Docência em Filologia e Língua Portuguesa) - Faculdade de Filosofia, Letras e Ciências Humanas, Universidade de São Paulo. 
- O espaço tensivo da controvérsia: uma abordagem discursivoargumentativa. Filologia e linguística portuguesa, São Paulo, n. 9, p. 293-310, 2007b.

. A vitalidade da retórica: atravessando os séculos. Língua e Literatura, São Paulo, n. 27, p.147-167, 2010.

MOTTA, Ana Raquel; SALGADO, Luciana (Org.). Ethos discursivo. São Paulo: Contexto, 2008.

MOUILLAUD, Maurice. O nome do jornal. In: ; PORTO, Sérgio Dayrell (Org.). O jornal: da forma ao sentido. 2.ed. Brasília: Ed.Universidade de Brasília, 2002. p. 85-98

NOBLAT, Ricardo. A arte de fazer um jornal cotidiano. São Paulo: Contexto, 2006.

O GLOBO. Rio de Janeiro, 2 abr. 1964a, p. 1.

. Rio de Janeiro, 3 abr. 1964b, p. 1.

. Rio de Janeiro, 10 abr. 1964c, p. 1.

OLIVEIRA, Maria Rosa Duarte de. João Goulart na Imprensa: de personalidade a personagem. São Paulo: Annablume, 1993.

ORLANDI, Eni Pulcinelli. Análise de discurso: princípios e procedimentos. 6.ed. Campinas: Pontes, 2005.

. O sujeito discursivo contemporâneo: um exemplo. In: INDURSKY, Freda; FERREIRA, Maria Cristina Leandro (Org.). Análise do Discurso no Brasil: mapeando conceitos, confrontando limites. São Carlos: Claraluz, 2007. p. 11-20.

PAES DE BARROS, Cláudia Graziano. "Compreensão ativa e criadora": uma proposta de ensino-aprendizagem de leitura do jornal impresso. São Paulo, 2005. 203f. Tese (Doutorado em Linguística Aplicada) - Pontifícia Universidade Católica de São Paulo.

PARRET, Herman. O pathos razoável. In: A estética da comunicação: além da pragmática. Tradução de Roberta Pires de Oliveira. Campinas: Ed.Unicamp, 1997. p. 107-133 [Original: The aesthetics of communication, pragmatics and beyond. New York: Springer-Verlag, 1993].

PÊCHEUX, Michel. Semântica e discurso: uma crítica à afirmação do óbvio. 3.ed. Tradução de Eni P. Orlandi et al. Campinas: Ed.UNICAMP, 1997 [1975]. 
- Discurso: estrutura ou acontecimento. Tradução de Eni P. Orlandi. Campinas: Pontes, 1990 [1983].

PERELMAN, Chaïm. O império retórico: Retórica e Argumentação. Porto: Ed. ASA, 1993.

Retóricas. São Paulo: Martins Fontes, 1997.

; TYTECA, Lucie Olbrechts-. Tratado da Argumentação: a nova retórica. Tradução de Maria Ermantina Galvão G. Pereira. São Paulo: Martins Fontes, 1996.

PINTO, Paulo Roberto Margutti. Análise do discurso e argumentação. In: MARI, Hugo et al (Org.). Fundamentos e dimensões da Análise do Discurso. Belo Horizonte: Carol Borges, 1999. p. 87-105.

PIOVEZANI FILHO, Carlos Félix. Política midiatizada e mídia politizada: fronteiras mitigadas na pós-modernidade. In: GREGOLIN, Maria do Rosário Valencise (Org.). Discurso e mídia: a cultura do espetáculo. São Carlos, SP: Claraluz, 2003. p. 49-64.

PIRIS, Eduardo Lopes. Elementos para um estudo do ethos numa polêmica parlamentar: análise dos pronunciamentos dos parlamentares que protagonizaram a sessão deliberativa de 12 de dezembro de 1968. São Paulo, 2006. 184f. Dissertação (Mestrado em Semiótica e Linguística Geral) - Faculdade de Filosofia, Letras e Ciências Humanas, Universidade de São Paulo.

Análise do Discurso e leitura de gêneros do jornal: uma experiência com o Programa "Teia do Saber". In: Anais do 4 Seminário Nacional "O Professor e a Leitura do Jornal", UNICAMP, Campinas, SP, 2008. Disponível em http://www.alb.com.br/anaisjornal/jornal4/comunicacoesPDF/17 analisedodiscursoPI RIS.pdf.

PLANTIN, Christian. L’argumentation. Paris: Seuil, 1996.

. L'argumentation dans l'émotion. Pratiques. Paris, n.96, p. 81-100, 1997.

. La construction rhétorique des émotions. In: RIGOTTI, Eddo (éd.). Rhetoric and argumentation. Proceedings of the IADA International Conference. Lugano, 1999. p. 203-219.

Se mettre en colère en justifiant sa colère. In: ; DOURY, Marianne; TRAVERSO, Véronique (Éds). Les émotions dans les interactions. Lyon: Presses Universitaires Lyon, 2000.

Structures verbales de l'émotion parlée et de la parole émue. In: COLLETTA, Jean-Marc; TCHERKASSOF, Anna (dir.). Les émotions. Cognition, langage et développement. Liège: Mardaga, 2003, p. 97-130. 
. Sans démonstrer ni s'émouvoir. In: MEYER, Michel. Perelman. Le renouveau de la Rhétorique. Paris: PUF, 2004. p. 65-80.

A argumentação: história, teorias, perspectivas. Tradução de Marcos Marcionilo. São Paulo: Parábola, 2008 [Original: L’Argumentation - Histoire, théories, perspectives. Paris: PUF, 2005].

. As razões das emoções. Tradução de Emília Mendes. In: MENDES, Emília; MACHADO, Ida Lúcia (Org.). As emoções no discurso. Vol.II. Campinas: Mercado de Letras, 2010. p. 57-80. [Original: Les raisons des émotions. In: BONDI, Marina (ed.). Forms of argumentative discourse: Per un'analisi linguistica dell'argomentare. Bologne: CLUEB, 1998. p. 3-50].

. Les bonnnes raisons des émotions. Principes et méthode pour l'étude du discours émotionné. Viena: Peter Lang, 2011.

PLANTIN, Christian; DOURY, Marianne; TRAVERSO, Véronique (Éds). Les émotions dans les interactions. Lyon: Presses Universitaires Lyon, 2000.

PLATÃO. Górgias ou a oratória. 3.ed. Rio de Janeiro: Bertrand Brasil, 1989.

PLEBE, Armando. Breve história da retórica antiga. Tradução de Gilda Naécia Maciel de Barros. São Paulo: Editora Pedagógica Universitária, 1978.

PLEBE, Armando; EMANUELE, Pietro. Manual de Retórica. Tradução de Eduardo Brandão. São Paulo: Martins Fontes, 1992.

POSSENTI, Sírio. Notas sobre a noção de acontecimento. In: FERNANDES, Claudemar Alves et al (Org.). Sujeito, identidade e memória. Uberlândia: Edufu, 2004. (Linguística in focus). p. 17-25.

ROBRIEUX, Jean-Jacques. Éléments de Rhétorique et d'Argumentation. Paris: Dunod, 1993.

SANTOS, João Bôsco Cabral dos. O pathos da memória na identificação de práticas de leitura. In: MENDES, Emília; MACHADO, Ida Lúcia (Org.). As emoções no discurso. Vol.Il. Campinas: Mercado de Letras, 2010. p. 113-122.

SEABRA, Roberto. Jornalismo político: história e processo. In: SEABRA, Roberto; SOUSA Vivaldo de (Orgs.). Jornalismo político: teoria, história e técnicas. Rio de Janeiro: Record, 2006, p.109-140.

SEIXAS, Lia Fonseca. Redefinindo os gêneros jornalísticos: Proposta de novos critérios de classificação. Covilhã: Labcom, 2009. 
SKIDMORE, Thomas Elliot. Brasil: de Castelo a Tancredo, 1964-1985. Rio de Janeiro: Paz e Terra, 1988.

SODRÉ, Nelson Wernek. Vida e morte da ditadura: vinte anos de autoritarismo no Brasil. Petrópolis: Vozes, 1984.

Era o golpe de 64 inevitável? In: TOLEDO, Caio Navarro de. 1964: visões críticas do golpe: democracia e reformas no populismo. Campinas: Unicamp, 1997. p. 103-107.

História da Imprensa no Brasil. 4. ed. Mauad, São Paulo, 1999.

SOULAGES, Jean-Claude. Les mises en scènes visuelles de l'information. InaNathan. Paris, 1999.

TÉTU, Jean-François. Le discours du journal. Lyon, 1982. Thèse de doctorat d'Etat.

L'émotion dans les médias: dispositifs, formes et figures. Mots (ENS Editions), Paris, n.75, p. 9-20, juillet 2004.

TOLEDO, Caio Navarro de. 1964: visões críticas do golpe: democracia e reformas no populismo. Campinas: Unicamp, 1997.

. O golpe contra as reformas e a democracia. Revista Brasileira de História. São Paulo, v. 24, n. 47, p.13-28, 2004.

A luta ideológica na conjuntura do golpe de 1964. E-premissas - Revista de Estudos Estratégicos. Campinas, Núcleo de Estudos Estratégicos da UNICAMP, n.1, p. 120-130, jun-dez 2006. Semestral. ISSN: 1981-1438. Disponível em: <http://www.unicamp. br/nee/epremissas/01.htm>. Acesso em: 10 jan. 2008.

TOULMIN, Stephen E. Os usos do argumento. 2.ed. Tradução de Reinaldo Guarany. São Paulo: Martins Fontes, 2006. [Original: The uses of argument. Cambridge: Cambridge, 1958].

TRAQUINA, Nelson. Teorias do Jornalismo: a tribo jornalística - uma comunidade interpretativa transnacional - vol. II. 2.ed. Florianópolis: Insular, 2008.

VIEIRA BARBOSA, Marinalva. Linguagem e emoções. Revista do GEL, São Paulo, v.6, n. 2, p. 104-124, 2009. 
ANEXOS

Anexo 1 - Primeira página do Correio da Manhã, edição de 02.04.1964

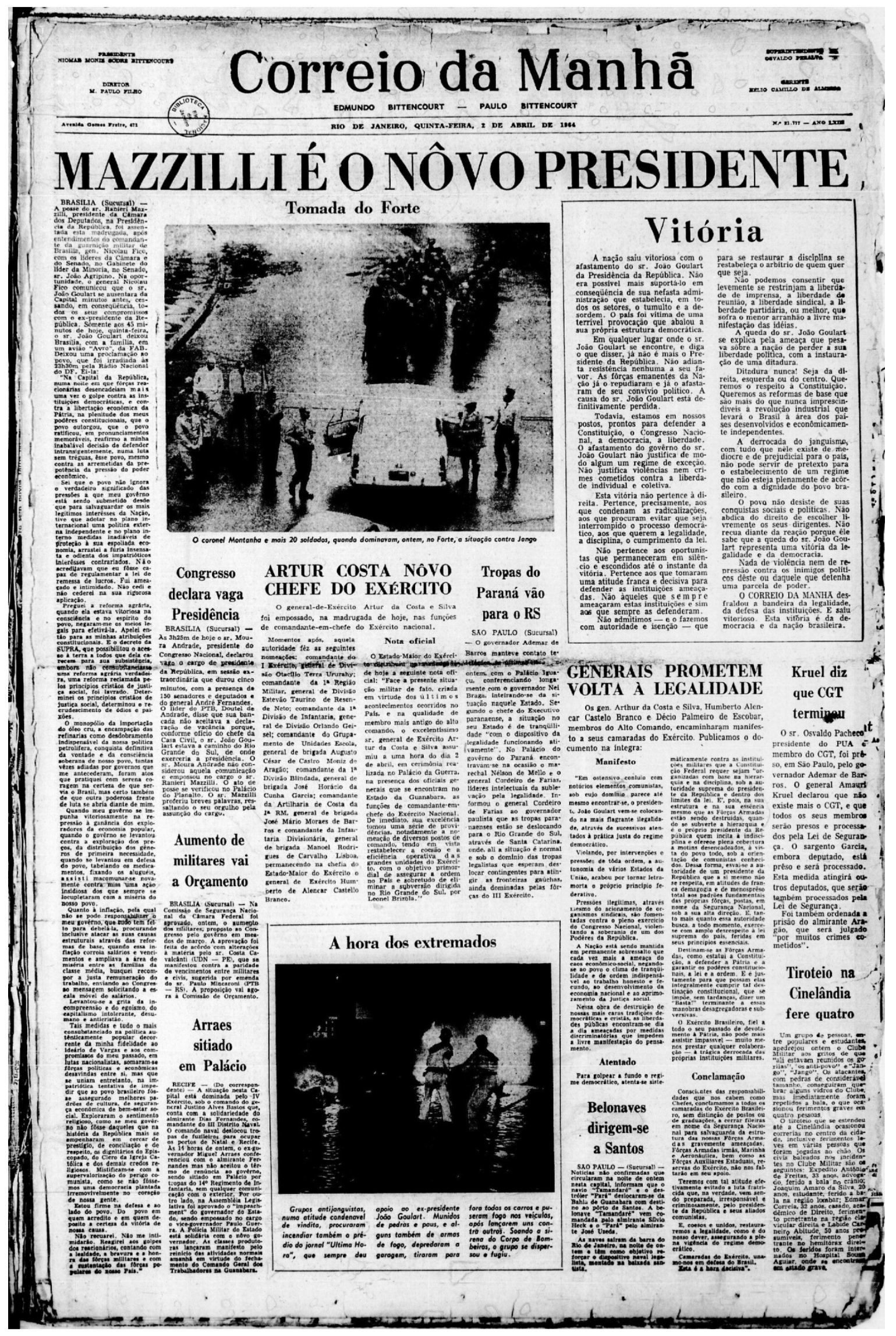


Anexo 2 - Primeira página d'O Globo, edição de 02.04.1964

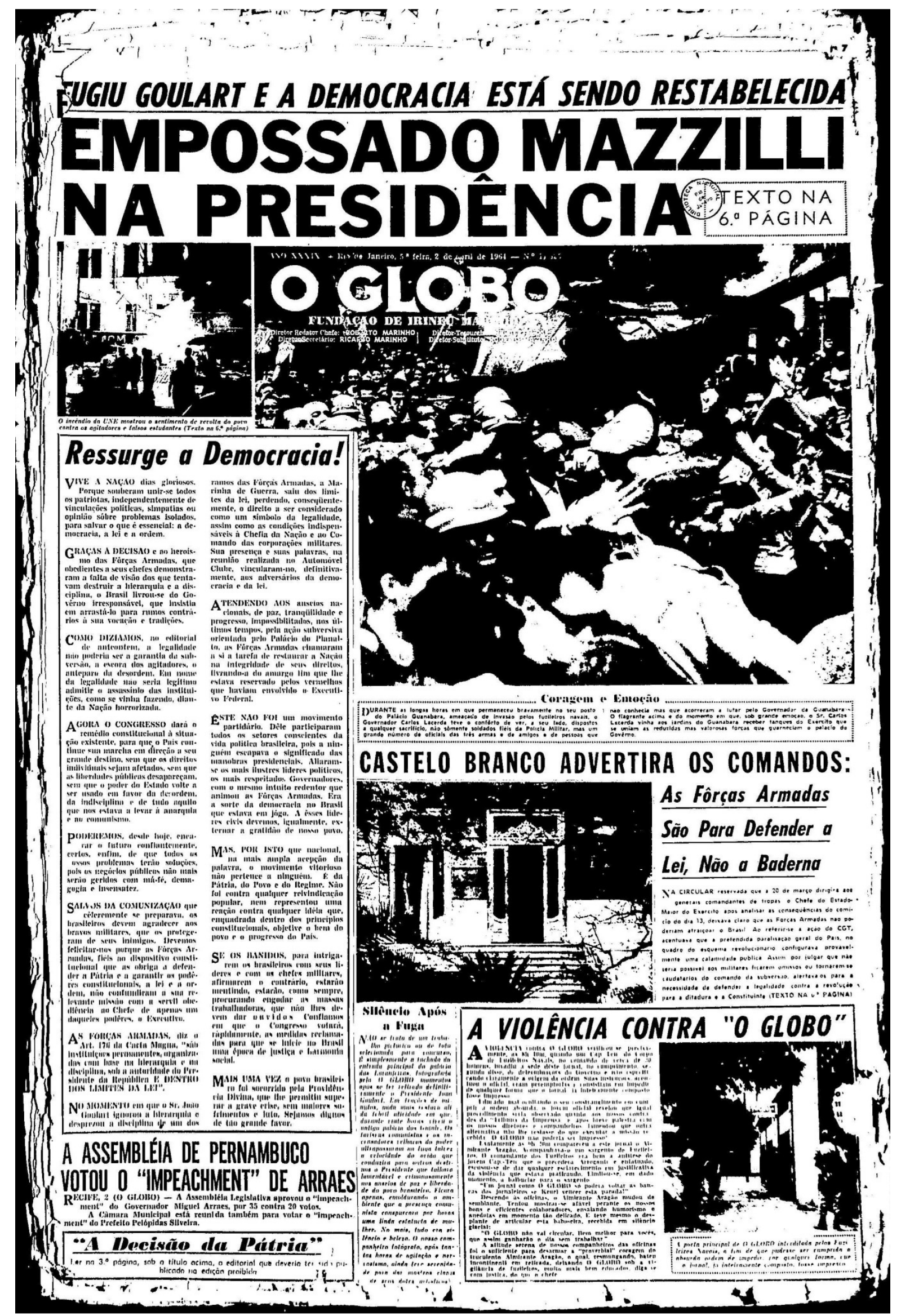


Anexo 3 - Primeira página do Correio da Manhã, edição de 03.04.1964

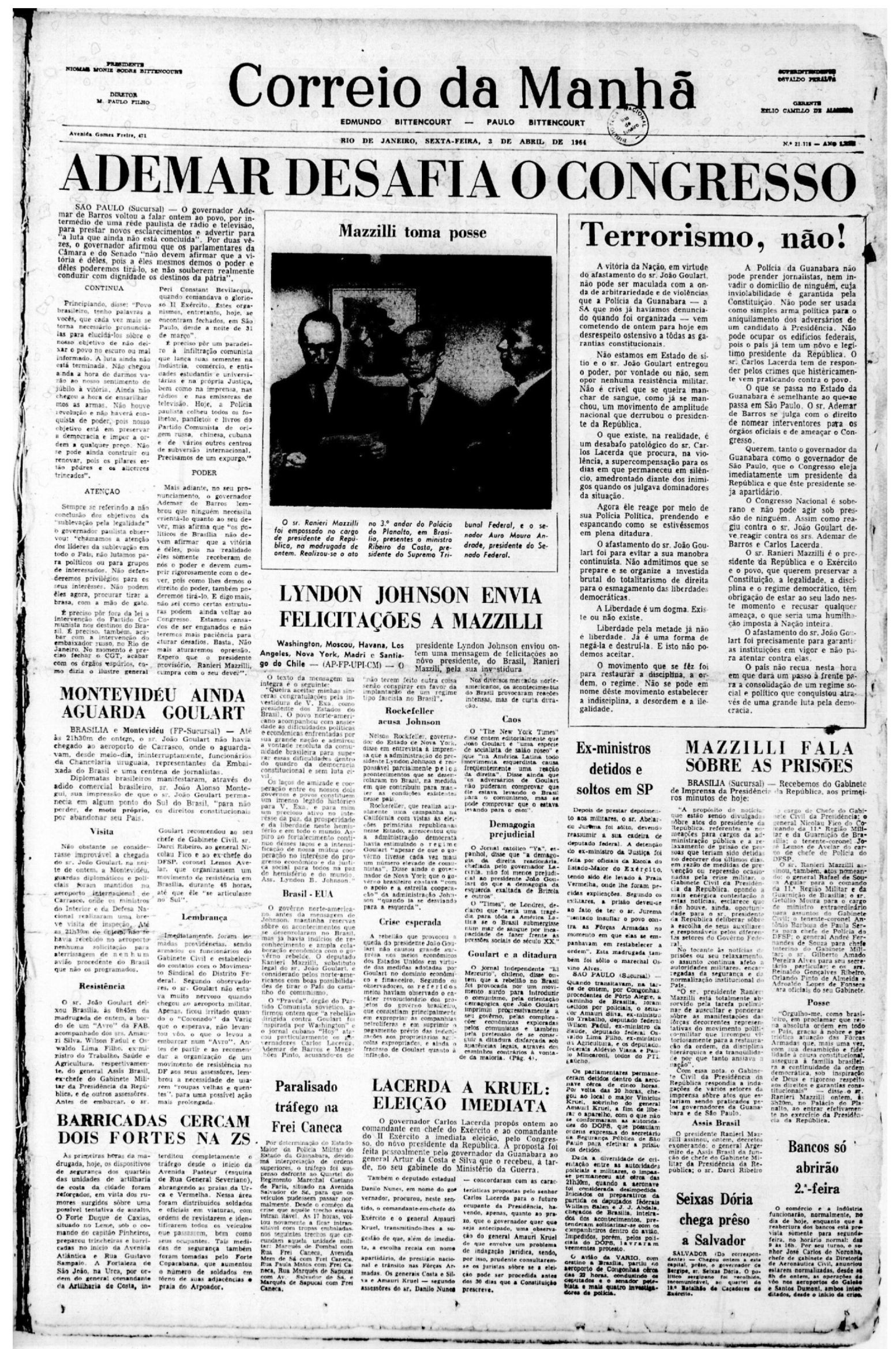


Anexo 4 - Primeira página d'O Globo, edição de 03.04.1964

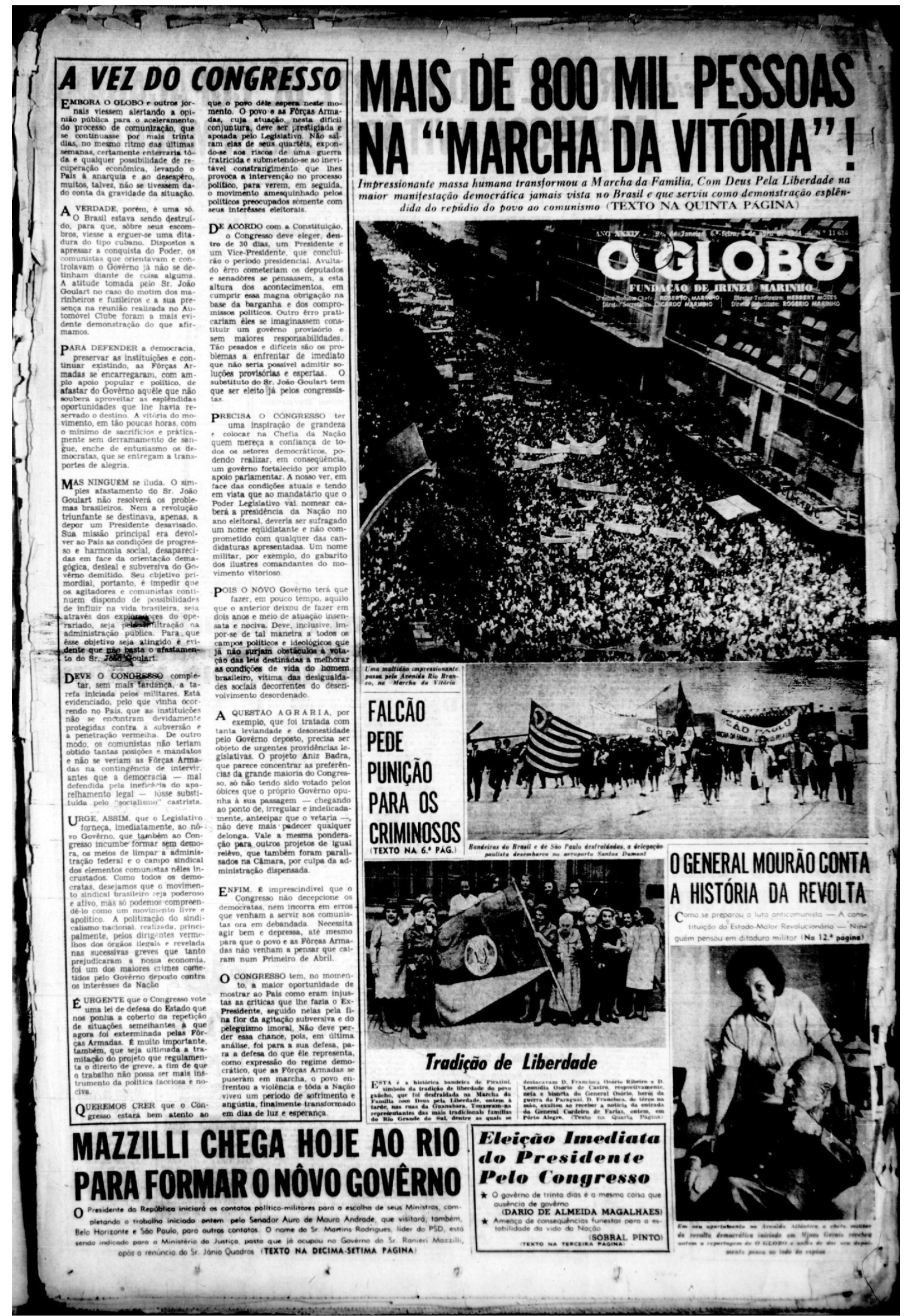


Anexo 5 - Primeira página do Correio da Manhã, edição de 10.04.1964

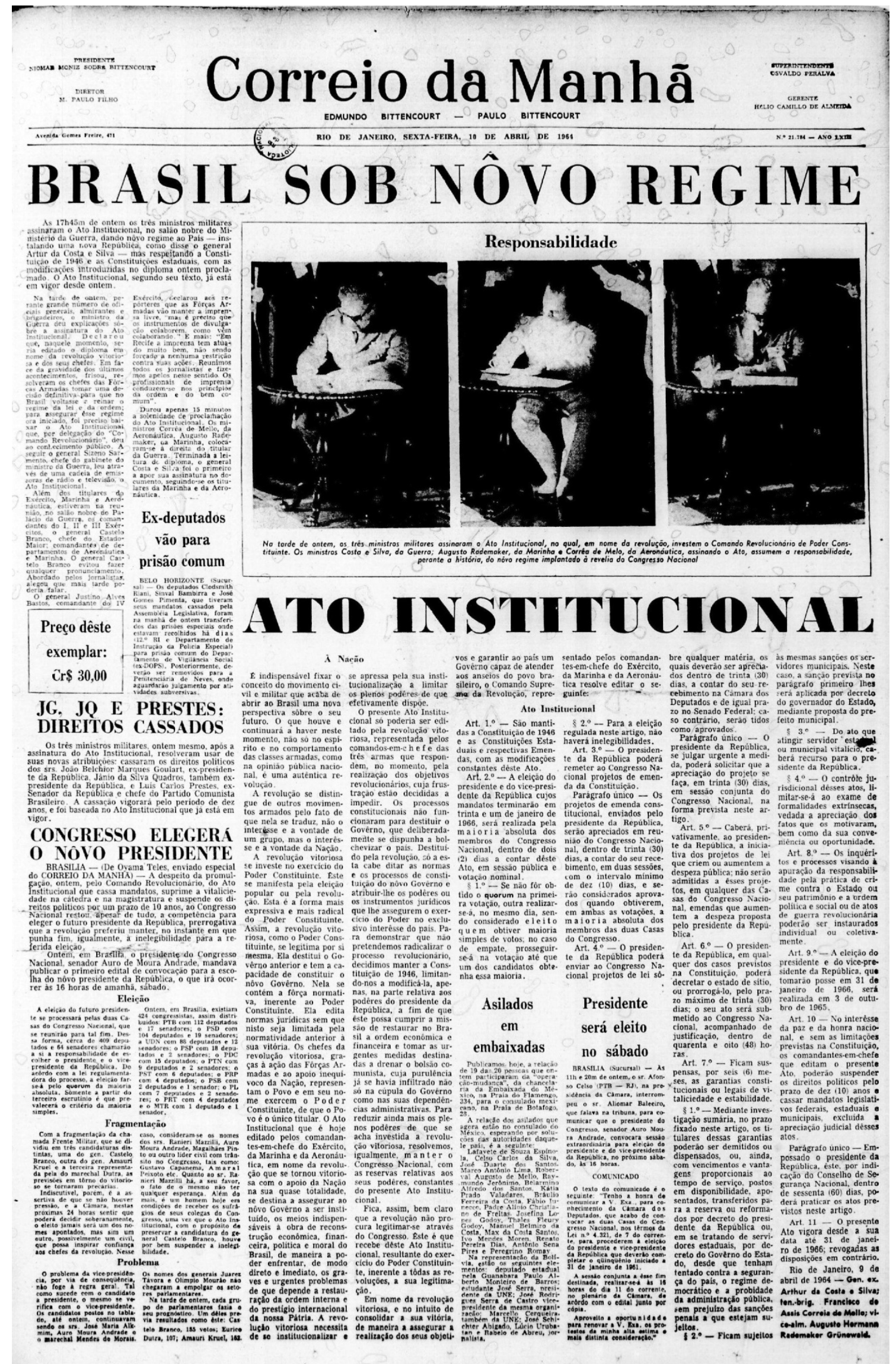


Anexo 6 - Primeira página d'O Globo, edição de 10.04.1964

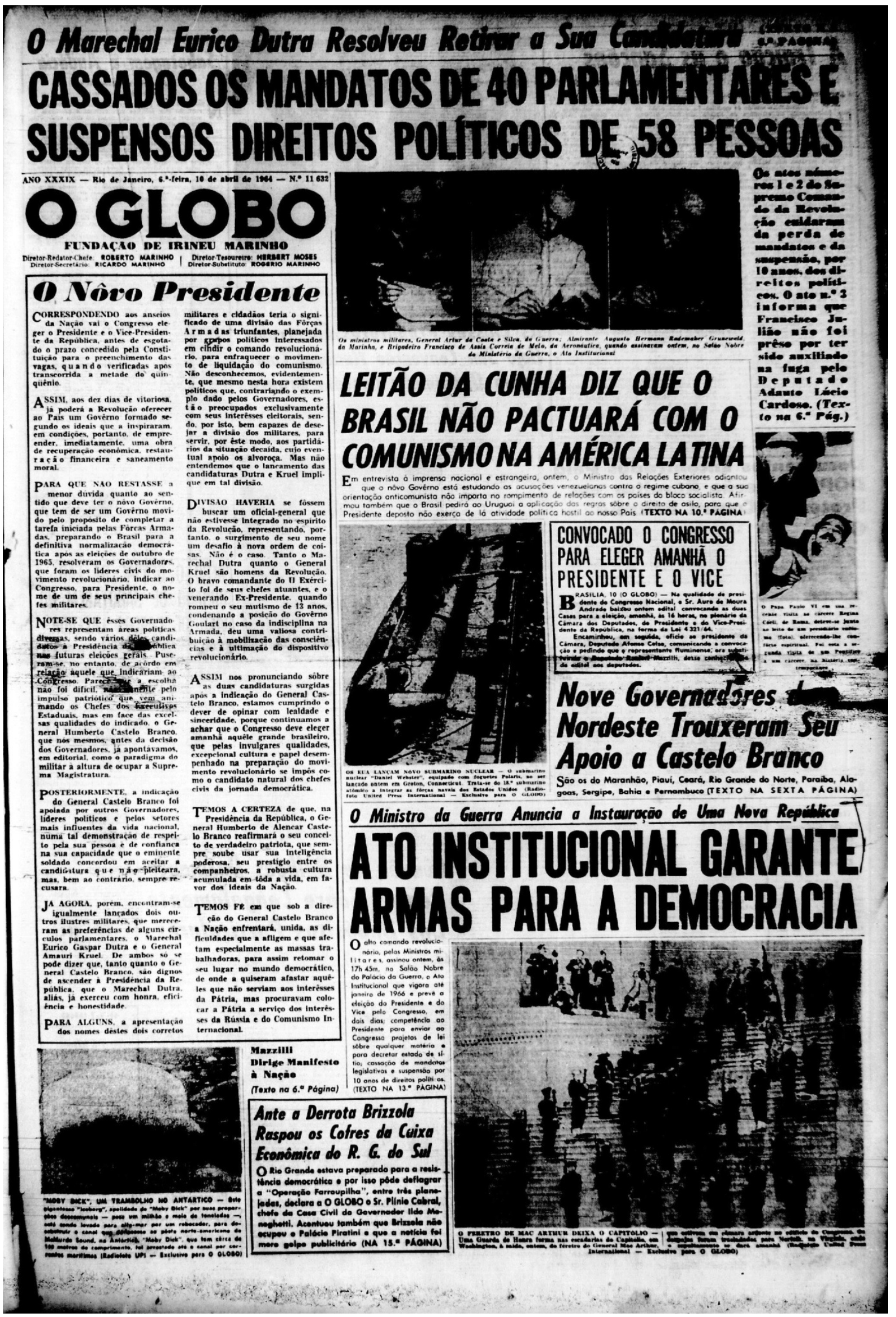

